\title{
EPITHELIAL AND BONE TISSUE MAST CELL POPULATIONS IN THE FEMALE RAT AS \\ INFLUENCED BY CALCIUM AND VITAMIN D DEFICIENCIES, OVARIECTOMY, AND ESTROGEN
}

\section{BY}

ROGENE TESAR

A DISSERTATION PRESENTED TO THE GRADUATE COUNCIL OF THE UNIVERSITY OF FLORIDA IN PARTIAL FULFILLMENT OF THE REQUIREMENTS FOR THE DEGREE OF DOCTOR OF PHILOSOPHY

\author{
UNIVERSITY OF FLORIDA
}

1982 
Copyright 1982

by

Rogene Tesar 
to my mother

who would have thoroughly enjoyed observing this entire experience 
ACKNOWLEDGEMENTS

My sincere appreciation is expressed to Dr. John P. Feaster, chairman of the supervisory committee, for undertaking that position, directing my academic program, and giving his time and expertise whenever needed. Very deep appreciation is also expressed to Dr. Morris Notelovitz, who served as co-chairman of the supervisory committee and directed the research with unfailing interest and support. These two individuals made possible the undertaking and completion of a very important goal.

Special thanks are also extended to Dr. Clarence Ammerman, Dr. James Dinning, and Dr. W.C. Thomas for their willing assistance in serving on the supervisory committee.

Thanks are given to Dr. Moreland, the veterinarians, and staff at the Department of Animal Resources who helped with the maintenance of the laboratory animals, especially Terry who aided me in the most unpleasant aspect. The technical advice and use of equipment and facilities offered by Dr. David Chen are also very much appreciated. Much thanks goes to I.C. Song for teaching me the surgical and other skills necessary in carrying out the experiments. Specially remembered are Pat Ruzakowski and Liu for their assistance. 
Terry Ansman and staff at the Department of Pathology are thanked for their time and efforts in teaching me the histology techniques required to carry out the work.

Sincere thanks are given to Dr. Hans Burchardt and staff, Department of Orthopaedics, for technical guidance in working with skeletal tissue. The assistance and expertise Dr. Gary Miller has provided for the biomechanical tests is also appreciated.

Inestimable thanks are extended to John Funk, Ray Smith, Pam Miles, John Easley, Dr. John Moore and others at the Nutrition Lab for providing knowledge, assistance, equipment and supplies, all necessary to complete the laboratory analyses within the project. Closely felt is the friendship of the graduate students there, especially Dawn, Oswaldo, Roberto and Joshua.

Remembered also is Lynda McKenzie who assisted with the densitometry and gave her time to listen and help. Bill Noffsinger is thanked for all the statistical analysis assistance. Pam Victor is thanked for the typing of this dissertation. Her proficiency has helped immeasurably.

The cooperation and financial assistance provided by the Department of Animal Science and The Center for Climacteric Studies, University of Florida, in order to carry out the research, are gratefully acknowledged. Sigma $x i$, the Scientific Research Society, has partially supported the study by a Grant-In-Aid of Research. Appendix A contains information relative to this grant. 
Lastly, but of great importance, sincere gratitude is also expressed to my children and husband for their patience, interest and support, which were entirely necessary. 
TABLE OF CONTENTS

PAGE

ACKNOWLEDGEMENTS $\ldots \ldots \ldots \ldots \ldots \ldots \ldots \ldots \ldots \ldots \ldots \ldots \ldots \ldots$ iv

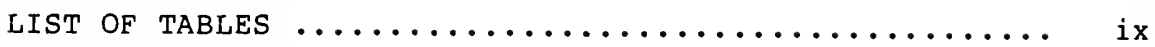

LIST OF FIGURES $\ldots \ldots \ldots \ldots \ldots \ldots \ldots \ldots \ldots \ldots \ldots \ldots \ldots \ldots \ldots$

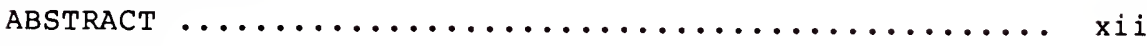

CHAPTER

I INTRODUCTION $\ldots \ldots \ldots \ldots \ldots \ldots \ldots \ldots \ldots \ldots \ldots \ldots \ldots \ldots$

I I REVIEW OF THE LITERATURE $\ldots \ldots \ldots \ldots \ldots \ldots \ldots \ldots \ldots$

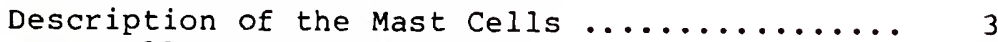

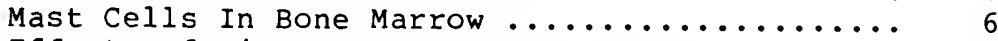

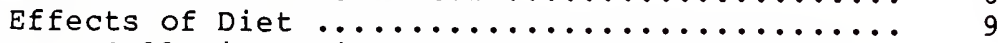

Mast Cells in Vaginal Tissue and Influence of Gonadal Hormones .................... 11

II MATERIALS AND METHODS .................. 14

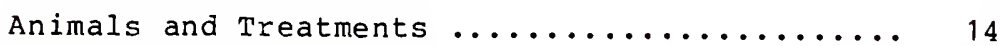

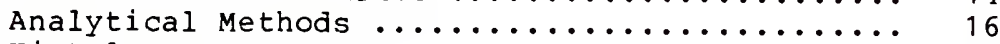

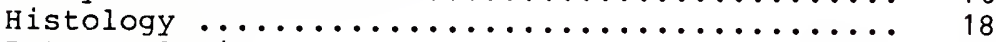

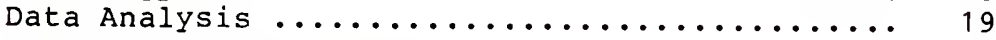

IV $\quad$ RESULTS AND DISCUSSION $\ldots \ldots \ldots \ldots \ldots \ldots \ldots \ldots \ldots \ldots$

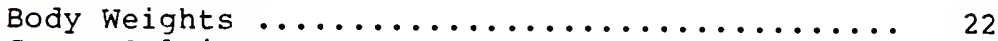

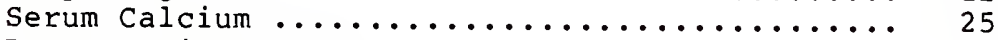

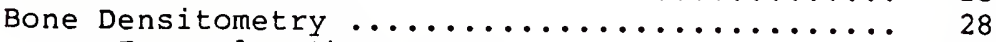

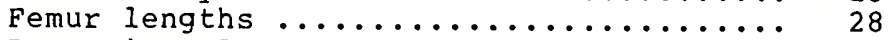

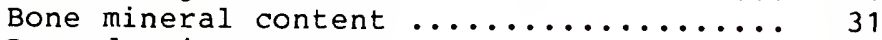

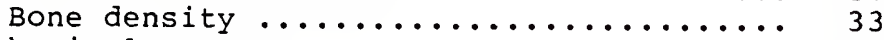

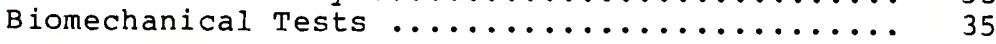

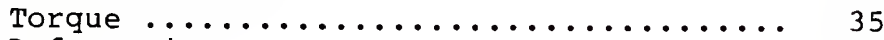

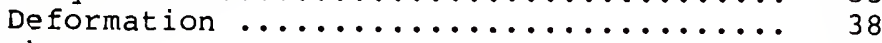

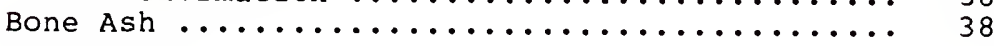

6


Table of Contents continued

CHAPTER

Mast Cells ......................... 41

Bone Marrow Mast Cells ................ 41

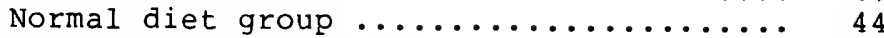

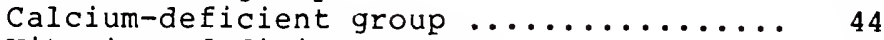

Vitamin D-deficient group ............ 45

Calcium- and vitamin D-deficient group .. 45

Vaginal Tissue Mast Cells .............. 47

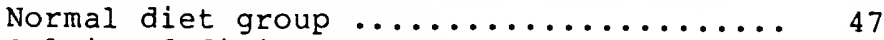

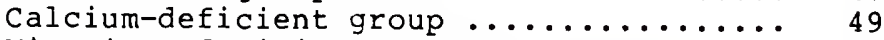

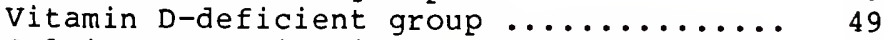

Calcium- and vitamin D-deficient group .. 49

$\mathrm{v} \quad$ CONCLUSIONS $\ldots \ldots \ldots \ldots \ldots \ldots \ldots \ldots \ldots \ldots \ldots \ldots \ldots \ldots$

APPENDICES

A SIGMA XI GRANT-IN-AID OF RESEARCH .......... 55

B LABORATORY ANIMAL USE .................. 66

C EXPERIMENTAL ANIMAL BODY WEIGHTS .......... 70

D COMPOSITION OF EXPERIMENTAL DIETS .......... 74

E SERUM CALCIUM ANALYSIS ................ 76

F DENSITOMETRIC BONE ANALYSIS ............. 83

G BIOMECHANICAL TESTING ................... 96

H ASH ANALYSIS ........................ 103

I $\quad$ MAST CELLS ........................ 113

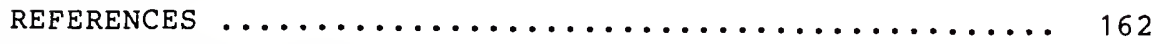

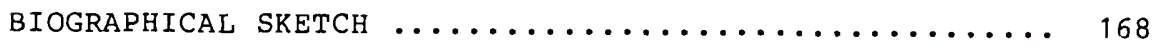


LIST OF TABLES

TABLE

PAGE

III.1 Study Design $\ldots \ldots \ldots \ldots \ldots \ldots \ldots \ldots \ldots \ldots \ldots \ldots \ldots \ldots \ldots \ldots$

IV. 1 Body Weight Gain as Affected by

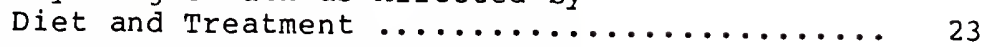

IV. 2 Effect of Diet and Treatment on

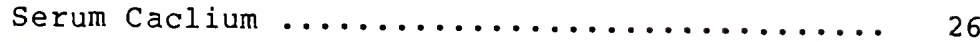

IV. 3 Effect of Diet and Treatment on Densitometric

Measurements of Rat Femurs ............... 29

IV. 4 Effect of Diet and Treatment on Biomechanical

Properties of Rat Femurs .................. 36

IV.6 Effect of Diet and Treatment on Bone Ash .... 39

IV. 6 Mast Cell Populations as affected by Diet and

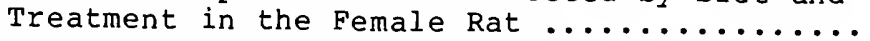

C. 1 Experimental Body Weights: Normal Diet ..... 70

C.2 Experimental Body Weights: -Ca Diet ........ 71

C.3 Experimental Body Weights: - D Diet ......... 72

C. 4 Experimental Body Weights: -Ca, -D Diet ...... 73

E. 1 Serum Calcium standards ............... 77

E.2 Serum Calcium Analysis Data: Normal Diet .... 79

E. 3 Serum Calcium Analysis Data: -Ca Diet ....... 80

E.4 Serum Calcium Analysis Data: -D Diet ....... 81

E. 5 Serum Calcium Analysis Data: -Ca, -D Diet .... 82

F.1 Densitometric Bone Analysis: Normal Diet ..... 87

F.2 Densitometric Bone Analysis: -Ca Diet ....... 89

F.3 Densitometric Bone Analysis: -D Diet ....... 91

F.4 Densitometric Bone Analysis: -Ca, -D Diet .... 93

F. 5 Densitometric Bone Analysis: Bone Length ..... 95 
List of Tables continued

TABLE

PAGE

G.1 Biomechanical Properties: Normal Diet ........ 99

G.2 Biomechanical Properties: -Ca Diet ............ 100

G.3 Biomechanical Properties: -D Diet ........... 101

G.4 Biomechanical Properties: -Ca, -D Diet ....... 102

H.1 Bone Ashing Analysis Data: Normal Diet ...... 105

H.2 Bone Ashing Analysis Data: -Ca Diet ......... 107

H.3 Bone Ashing Analysis Data: -D Diet .......... 109

H.4 Bone Ashing Analysis Data: -Ca, -D Diet ...... 111

I. 1 Mast Cell Count--Vaginal Tissue: Normal Diet .. 113

I.2 Mast Cell Count--Vaginal Tissue: -Ca Diet .... 117

I.3 Mast Cell Count--Vaginal Tissue: -D Diet ..... 122

I.4 Mast Cell Count--Vaginal Tissue: -Ca, -D Diet. 126

I.5 Mast Cell Count--Bone Marrow: Normal Diet .... 129

I.6 Mast Cell Count--Bone Marrow: -Ca Diet ....... 133

I. 7 Mast Cell Count--Bone Marrow: -D Diet ....... 138

I.8 Mast Cell Count--Bone Marrow: -Ca, -D Diet .... 142 


\section{LIST OF FIGURES}

FIGURE

PAGE

IV. 1 Body Weight Gains in Female Rats .......... 24

IV.1 Femur Length by Photonabsorptiometry ....... 30

IV. 3 Bone Mineral Content of Rat Femurs ........ 32

IV. 4 Linear Bone Density of Rat Femurs ......... 34

IV. 5 Torque Required for Fracture ............ 37

IV. 6 Femoral Deformation Prior to Fracture ....... 40

IV. 7 Bone Marrow Mast Cell Populations in

the Female Rat ...................... 43

IV. 8 Vaginal Tissue Mast Cell population in

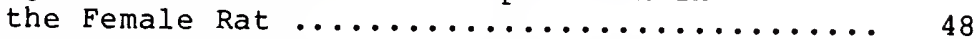

F.1 The Norland Digital Bone Densitometer ...... 86

F. 2 Printout Display of Rat Femur Profile $\ldots \ldots \ldots . . .86$

G.1 The Rapid Loading Torsional Testing Machine ... 98

G.2 Representative Torque-Deflection Curves ...... 98

I. 1 Photomicrograph of Mast Cells--Bone Marrow:

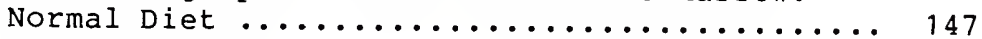

I. 2 Photomicrograph of Mast Cells--Bone Marrow:

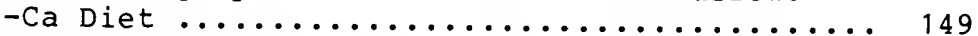

I. 3 Photomicrograph of Mast Cells--Bone Marrow:

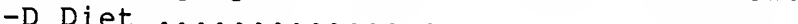

I. 4 Photomicrograph of Mast Cells--Bone Marrow:

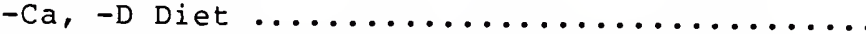

I.5 Photomicrograph of Mast Cells--Vaginal Tissue:

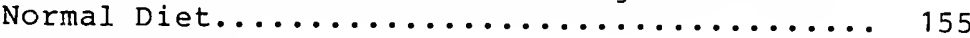

I. 6 Photomicrograph of Mast Cells--Vaginal Tissue:

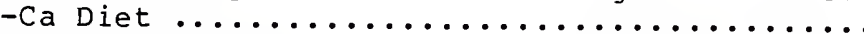

I.7 Photomicrograph of Mast Cells--Vaginal Tissue:

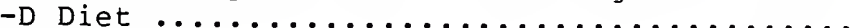

I. 8 Photomicrograph of Mast Cells--Vaginal Tissue:

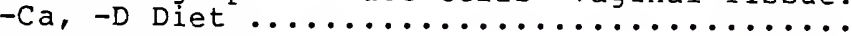


Abstract of Dissertation Presented to the Graduate Council of the University of Florida in Partial Fulfillment of the Requirements for the Degree of Doctor of Philosophy

EPITHELIAL AND BONE TISSUE MAST CELL POPULATIONS IN THE FEMALE RAT AS INFLUENCED BY CALCIUM AND VITAMIN D DEFICIENCIES, OVARIECTOMY AND ESTROGEN

\section{By}

Rogene Tesar

May 1982

Chairman: Dr. J.P. Feaster

Cochairman: Dr. Morris Notelovitz

Major Department: Animal Science

Effects of dietary deficiencies on mast cell populations in the bone marrow and vaginal epithelial tissue of rats were investigated. Additionally, effects of exogenous estrogen, bilateral ovariectomy, and a combination of the two treatments on mast cell populations were observed in these two tissues in rats on normal and deficient diets.

Two-month old, female sprague-Dawley rats were fed calcalcium- and vitamin D-deficient diets for five weeks. One group of rats was given estradiol by injection $(100 \mu \mathrm{g} / .1 \mathrm{ml})$ three times a week for the duration of the experiment, another group was ovariectomized, a third group received both treatments, while a fourth, untreated group served as a control group. 
Dietary-induced osteopenia was evidenced by densitometric measurements and bone ash of the rat femur. Significant decreases in bone mineral content $(P<.005)$ due to diet were observed. Bone ash values were also significantly low due to $\operatorname{diet}(\mathrm{P}<.0005)$.

Femur length, measured by photonabsorptiometry, was found to be decreased due to (a) dietary deficiencies of calcium and vitamin $D(P<.005)$; (b) estrogen administration $(\mathrm{P}<.005)$; and $(\mathrm{C})$ ovariectomy $(\mathrm{P}<.005)$.

Contrary to expectations, bone marrow mast cell populations were not altered by dietary deficiencies in untreated rats. This result may be due to the age of the rat when begun on the deficient diet (two months old) and to the duration of the imposed diet deficiencies (five weeks). Dietary deficiencies reduced marrow mast cell counts in estrogen treated rats, however $(P<.05)$. Ovariectomy induced a reduction of mast cells in the bone marrow of calcium- and vitamin $D$-deficient rats $(P<.01)$, which suggests that bone is an estrogen sensitive tissue even though estrogen receptors are not present in bone.

Vaginal tissue mast cells were not significantly altered in number by dietary deficiencies except when rats were estrogen treated $(P<.05)$. The most significant finding was that of mast cell population increases in vaginal tissue as a result of ovariectomy $(P<.01)$ in all dietary groups. 
The removal of endogenous estrogen by ovariectomy in the female rat was found to affect both bone marrow and vaginal tissue mast cell populations. The relevance of this finding remains to be determined. 
Rapid bone loss with resultant osteoporosis affects 25 to $30 \%$ of all postmenopausal women (Urist, 1971) and about $75 \%$ of women who have undergone a bilateral ovariectomy. The significance of this condition is associated not only with pathological fractures and potential invalidism but also with the premature death of these women. The early diagnosis of this condition and measurement of treatment response present two problem areas in clinical management. To date there is no universally applicable, noninvasive method for detecting the early stages of rapid bone loss in humans.

Research has shown that mast cells, found in increased numbers in the bone marrow of osteoporotic and calcium-deficient subjects, accompany local loss of bone mass. The present study seeks to determine whether vaginal epithelial mast cell populations, as well as bone marrow populations are affected by dietary deficiencies of calcium and vitamin D, exogenous estrogen, and ovariectomy in the female rat. Should such alterations be found in the female rat, similar changes in populations might be expected in the osteoporotic human female. Tissue biopsy of vaginal epithelium to determine mast cell populations could provide a relatively noninvasive method for detecting osteomalacia and conditions 
involving increased bone resorption such as osteoporosis. The procedure might also be used to assess treatment efficacy.

Therefore, two hypotheses were tested in this investigation:

(a) Dietary calcium- and vitamin D-deficiencies produce changes in mast cell populations in female rat bone marrow and vaginal epithelium.

(b) Exogenous estrogen, bilateral ovariectomy, or a combination of the two treatments alters mast cell populations in bone marrow and vaginal tissue of calcium- and vitamin D-deficient female rats.

Other parameters considered and investigated in this study were:

(a) weight changes of the laboratory animals during the experimental period

(b) serum calcium concentration

(c) bone mineral content, density, and length

(d) torsion and deformation of the rat femurs

(e) ash content of the femurs. 
CHAPTER II

REVIEW OF THE LITERATURE

Addressed in the literature review are a description of the mast cell and the activity of two constituents, histamine and heparin. Research involving the mast cell in bone marrow of the rat and human is reviewed. Effects of dietary deficiencies, specifically those of calcium and vitamin D, on the rat mast cell in bone tissue are examined. Also cited are the few studies concerning mast cells in vaginal tissue and those relating to the effects of gonadal hormones on skeletal and vaginal tissues.

\section{Description of the Mast Cell}

Naming the specialized histiocytes as mast cells has been credited to Paul Ehrlich when he suggested, in 1877, that the cells arose from connective tissue cells which had been well-fed, or 'masted' (Wilhelm et al., 1978). The German masten (to feed) or mastzellen (mast cells), from which the name originated, appropriately describes their usually full appearance. This is due to a high content of cytoplasmic granules.

Pathak and Goyal (1973) state that two separate types of mast cells occur (1) large spindle shaped, fusiform or cylindrical cells with or without elongated processes and (2) small, round, or elliptical cells. Riley (1959) also 
described differences in rat mast cells and distinguished between two types based on granule maturation. Differences also exist when mast cells are examined with electron microscopy (Combs et al., 1965).

Rat peritoneal fluid, the most common source of mast cells for laboratory investigation, exhibits round mast cells, 13.5 to $17 \mu \mathrm{m}$ in diameter, each with a round or oval nucleus. Cytoplasmic granules are approximately .7 $\mu \mathrm{m}$ in diameter (Yong et al., 1975).

In an extensive quantitative analysis of rat mast cell structure, Helander and Bloom (1974) report an average mast cell diameter as $11 \mu \mathrm{m}$, granule diameter as $.78 \mu \mathrm{m}$, with the nucleus occupying $10.7 \%$ of the cell. The size, shape, staining properties, and distribution of mast cells vary with the tissue and species of animal studied (Wilhelm et al., 1978). Rat tissues abound in mast cells, whereas tissues of the rabbit contain related basophils often referred to as blood mast cells. Tissues in man and the guinea pig exhibit both mast cells and basophils.

A well-known characteristic of both mast cell and basophil leukocyte granules is an exhibition of metachromasia upon treatment with certain basic dyes such as toluidine blue, methylene blue, alcian blue, and azure A. These stains are used to identify and demonstrate the mast cells in tissues. Since many differences in mast cell reactivity towards these dyes occur within and between species, an extensive investigative interaction among histological studies, identification of cell constituents, and physiological 
functions of the mast cells exists. The constituents of the mast cell granules, specifically the acidic mucopolysaccharides, are responsible for the various staining properties of the cells. However, partly because of the chemical diversity of the granular contents, mast cell functions in health or disease remain an enigma.

In 1937, the metachromatic component of the mast cell was reported to be heparin (Jorpes et al., 1937); and since then, the mast cell in hepatic tissue has been considered as the only endogenous source of heparin production (Riley, 1962). A protein matrix is thought to bind anionic heparin in the mast cell granule, possibly by sulfate groups. Heparin, in turn, binds histamine and other basic nitrogen-containing compounds such as serotonin (Schubert, 1968). Histamine levels in tissues correlate with the mast cell count and a very large proportion of rat histamine formation takes place in the bone marrow.

The close histological relationship of mast cells and blood and lymph vessels is well-known. Small vessels are the prime target of histamine-mediated inflammatory reactions. Histamine is known to cause contraction of part of smooth muscle (mainly the bronchioles), dilate blood capillaries, and increase their permeability (Rahima and Soderwall, 1977).

In-vitro laboratory studies of the mast cells (in certain tissues and species) demonstrate that histarnine is released by liberators such as stilbamidine, $48 / 80$, or protamine sulfate by displacing the heparin-bound histamine (Schubert, 1968). 
Sudden degranulation of mast cells may cause adverse reactions since large amounts of histamine are released into the extracellular space. This release usually occurs in response to a type I antigen-antibody reaction on the surface of mast cells that have been previously sensitized by cellbound Ig E antibody (Coombs and Gell, 1975). Allergic rhinitis, allergic asthma, urticaria, angioedema, and mastocytosis constitute some manifestations of extensive degranulation. An editorial by Kaliner (1979) details this aspect of the mast cell's varied activities.

\section{Mast Cells in Bone Marrow}

In addition to its role in immediate hypersensitivity reactions, histamine has been reported to affect bone remodeling and maturation (Norton et al., 1969). Systemic mastocytosis in urticaria pigmentosa has been accompanied by marked bone remodeling, bone hypertrophy (Sagher et al., 1956), and osteosclerosis (Kruse et al., 1973).

In this same regard, the acid glycosaminoglycan, heparin, in addition to its anticoagulant property, has been considered as a bone resorbing and osteoporosis producing agent. This is especially true with the use of high doses of the anticoagulant for long periods of time (Goldhaber, 1965; Griffith et al., 1965; Jaffe and Willis, 1965; Wise and Hall, 1980). Heparin has been reported to stimulate bone collagenase activity in the rat (Asher and Nichols, 1965) and to potentiate the action of parathyroid hormone (Goldhaber, 1965), suggesting inducement of osteoporosis. A review of the relationship 
between mast cells, heparin, and osteoporosis has been provided by Hegsted (1969).

Many reports of heparin use with resulting skeletal problems involved the use of heparin for control of blood coagulation. It has been documented that heparin extracted and purified from tissues rich in mast cells and reinjected by the physician behaves differently from endogenous heparin (Jaques et al., 1977). Only in the dog has the hepatic release of heparin been shown to have a rapid anticoagulant effect in the circulation. Several species have no heparin in the mast cell; its metachromasia is attributed to other sulfated mucopolysaccharides.

Osteoporosis has been viewed by some as a sequel to diminished blood flow through the marrow (Burkhardt, 1973). Contracted arterioles in mastocellular lesions of the bone marrow in human osteoporotics provide evidence for this concept (te Velde et al., 1978).

Increased numbers of bone marrow mast cells have been reported in osteoporosis (Frame and Nixon, 1968; Kruse et al., 1973; Peart and Ellis, 1975). Two theories have been have been expressed (1) mast cells induce porosis (Frame and Nixon, 1968) and (2) mast cells oppose the porosis (Kruse et al., 1973).

Increased mast cell numbers have been associated with bone resorption in regenerating parts of the marrow. Gillman (1958) noted increased mast cells in long bone marrow of rats fed sweet pea seeds containing a lathyrogenic agent. He 
distinguished between newly formed and old femoral shafts, with the increased number found in the marrow of the newly formed shaft. Severson (1969) showed that mast cells secrete a factor necessary for hydrolytic enzyme release in regions of increased resorption and remodeling. Walker (1970) reported an eight-fold increase of mast numbers in regenerating rat femoral marrow after mechanical disruption when compared to the unoperated contralateral femur. Hypophysectomy resulted in an even greater increase and longer effect.

Extensive studies in bone repair (Lindholm et al., 1967, 1969) demonstrated active involvement by mast cells, increased mast cell numbers in callus formation, and mast cell provision of alkaline phosphatase, phosphorylase, and other enzymes essential for endochondral ossification.

Human alveolar bone resorption in chronic periodontal disease is associated with increased mast cell counts in gingival tissue (Shapiro et al., 1969; Riley, 1959; Sognnaes, 1965). Other investigators (Carranza and Cabrini, 1955; Calonius, 1960; Dummet et al., 1961) failed to confirm this finding.

In hyperparathyroidism, both the resorption and the formation of bone are stimulated, but greater increases in bone resorption occur (Bonucci et al., 1978). Mast cells have been reported in fibrotic marrow spaces in human hyperparathyroid patients. Other researchers (Rockoff and Armstrong, 1970) found that low doses of parathyroid hormone chronically administered to rats produced mast cell hyperplasia in the 
tibial metaphyseal marrow, without alterations of serum calcium or phosphorous.

Secondary hyperparathyroidism is known to result from lowered serum calcium levels and is thought to be a mechanism whereby low dietary calcium intakes promote mast cell increases in bone.

\section{Effects of Diet}

As early as 1922, increase of tissue basophils in the immediate vicinity of the bone trabeculae and marked resorption of bone in rats on calcium deficient diets were reported (Shipley and Park, 1922). Urist and McLean (1957) identified those basophils as mast cells. They also maintained rats on low calcium, low vitamin D, and high phosphorus diets which produced rickets, osteoporosis, and osteitis fibrosa as well as increased endosteal mast cells. Cass et al. (1958) confirmed the results of increased bone mast cells in rats fed calcium-deficient diets and found an increase in bone marrow content of histamine and 5-hydroxytryptamine, another mast cell mucopolysaccharide. Rockoff and Armstrong (1970) also administered a calcium-deficient but vitamin D-adequate diet to a group of rats, with bone marrow mast cell hyperplasia resulting in all test animals. In providing hypocalcemiainducing vitamin D-deficient and calcium- and vitamin Ddeficient diets to rats, Rasmussen (1972) observed significant increases in tibial metaphyseal bone marrow mast cells. Parathyroidectomy caused a significant reduction in mast cells, again suggesting secondary hyperparathyroidism as a 
mechanism for increased mast cell populations in bone. Other rats given low calcium and high phosphorus diets with and without vitamin D exhibited hypocalcemia, rachitic bone changes, increased bone resorption and increased mast cells in metaphyseal areas of long bone but not in the epiphyses or caudal vertebrae (Feik and Storey, 1979); however, it was not possible to relate the mast cell increases to specific areas of bone formation or resorption, as had been planned.

In dietary calcium- and vitamin D-deficient rats with induced fracture callus, mast cell counts in the callus approximated 200 to 300 cells per $\mathrm{mm}^{2}$ which rose to 1,900 cell per $\mathrm{mm}^{2}$ until 35 days after fracture. These mast cells were mostly degranulated. Normal rats exhibited strongly granulated mast cells, 2,000 to $4,000 \mathrm{~mm}^{2}$ for the first two-month period with remarkably decreased levels thereafter. Mast cell numbers were correlated with mineralization after fracture (Lindholm et al., 1972).

Accumulations of mast cells in healing sockets or extracted mandibular first molars were found in rats fed calcium-deficient diets, with control rats exhibiting only an occasional mast cell (Smith, 1974). Besides the fact that mast cell numbers were examined in different bones in the two studies, the contradictory findings were not explained.

Other dietary deficiencies have also affected mast cell populations in bone marrow. Bélanger (1978) found a significant increase of bone marrow mast cells in rats on zinc 
deficient diets, and also on magnesium-deficient diets (1977). Concurrent decreases in skin mast cell numbers of the magnesiumdeficient rats agree with the findings of Bois (1962).

Mast Cells in Vaginal Tissue and Influences of Gonadal Hormones

Vaginal tissue mast cell population studies in the rat are essentially nonexistent. Salvi (1952) found mast cells more abundant and with greater metachromatic properties in the mouse vagina than in the uterus. After daily estrogen administration, adult mouse vaginal tissue revealed a considerable increase in the number of mast cells (Arvy, 1955). Westin and Odeblad (1956) also investigated the influence of ovarian hormones on mast cells in the mouse vagina. Darker metachromasia in the vagina than in the uterus and difficulty in detecting granules were experienced. The control group had the highest number of vaginal tissue mast cells and also the highest variation in number per field examined. The estrogen treated groups had a significantly reduced number; intermediate numbers were observed when estrogen plus progesterone was administered. Mast cells of the skin remained constant. The estrogen effect on the mast cells was considered a local process within the reproductive organs. Zwillenberg (1958) noted a variable occurrence of mast cells in the vaginal epithelium of human subjects.

Discrepancies in results among studies may be due, in part, to differences in estrogen dosage. Iversen (1962) 
notes that, while small doses of estradiol decreased the number of uterine mast cells in the guinea pig, prolonged treatment with large doses had an opposite effect.

Although there are mast cell studies which investigated the effect of gonadal hormones in various tissue (Constantinides and Rutherdale, 1954; Asboe-Hansen, 1956; Johansson and Westin, 1958; Smith and Lewis, 1958; Schiff and Burn, 1961; Kameswaren et al., 1978), few reported on bone tissue. Bélanger (1977), in his study with magnesium deprived rats, administered large doses of testosterone to males and estradiol to females. This treatment depressed the mast cell population increase in the bone marrow and moderated skin mast cell loss.

Similarly, there is no reference in the literature concerning the effect of ovariectomy on mast cells in bone or vaginal tissue. The mice in the study of Westin and Odeblad (1956) were all spayed so that effect of ovariectomy could not be compared to control groups. Two studies reported that ovariectomy has no effect on uterine mast cells in guinea pigs or hamsters (Iversen, 1962; Harvey, 1964).

Because of the differences in mast cell populations, structure, function and activity in various species (and in tissues within the same species), information cannot be extrapolated from one species to another. Because of the various mast cell constituents and their resulting diverse functions and actions in tissues, inconsistencies in results will continue to be reported. However, in the recent past, 
much new information on the mast cell has been brought forth. The particular role of the mast cell in the pathogenesis of the osteoporoses and other demineralizing bone diseases remains in need of further investigation. 
CHAPTER III

MATERIALS AND METHODS

\section{Animals and Treatments}

To monitor the care, treatment, and use of laboratory animals at the University of Florida, the All University Committee on the Care and Use of Laboratory Animals requires specific information pertaining to research involving laboratory animals. The application requesting use of laboratory animals for this particular research project as submitted to the Committee and its approval are found in Appendix B.

One hundred thirty-six female sprague Dawley rats, ${ }^{1}$ 9 weeks of age and weighing approximately $180 \mathrm{~g}$ at the start, were used for the research.

The Health Center Animal Resources Department, University of Florida, provided housing for the animals. The rats were kept in galvanized wire cages, two to a cage, in a room maintained constantly at $24^{\circ} \mathrm{C}$ and $60 \%$ humidity. The rats were weighed at least once a week for the 4 to 5 week experimental period. Appendix $\mathrm{C}$ contains data on the animal weights.

The animals were divided into the following dietary groups:

1 Outbred laboratory sprague-Dawley rats were obtained from Harlan·Sprague-Dawley, Madison, WI 53711. 
I. Normal (control) rats (semipurified complete diet)

II. Calcium-deficient (-Ca) rats (calcium-deficient diet)

III. Vitamin D-deficient (-D) rats (rachitogenic diet; calcium to phosphorus ratio of $4.2: 1$ )

IV. Calcium- and vitamin D-deficient $(-\mathrm{Ca},-\mathrm{D})$ rats (custom formulated calcium- and vitamin D-deficient diet).

Appendix $D$ contains information on dietary formulations.

Each dietary group consisted of 32 rats, except for group II, in which there were 40 . The diets (pelleted) and distilled water were offered ad libitum. Group III rats were borderline vitamin $D$-deficient at the beginning of the experimental period. One rat in group IV was rejected because of a malfunctioning eye.

Upon receipt of the animals and prior to further treatment, each rat was tested by vaginal smear daily for an 8 day period to determine presence of estrous cycling. Each rat presented with at least once cycle, demonstrating reproductive capability and ascertaining endogenous circulating estrogen.

Half the rats in each group were bilaterally ovariectomized. Sham ovariectomies were performed on the remaining rats in each group. The combination of ketamine and xylazine (Van Pelt, 1977), at a concentration of $87 \mathrm{mg}$ ketamine and $13 \mathrm{mg}$ xylazine per $\mathrm{kg}$ body weight of rat, was used to induce surgical anesthesia. One rat in group II died as a result of the surgery 
One-half of the ovariectomized and one-half of the shamoperated rats in each group were injected three times per week under the dorsal skin with $.1 \mathrm{ml}$ of a solution of estradiol valerate $(100 \mu \mathrm{g} / .1 \mathrm{ml})$ in sesame oil (12 injections per rat total). Concurrently, the remaining rats in each group were injected with $.1 \mathrm{ml}$ of sesame oil as a control measure.

After the five to six week experimental period, all animals were killed by decapitation.

Table III. 1 summarizes the research design described.

TABLE III. 1

STUDY DESIGN

Diet Group

$\frac{\text { Normal }}{(\mathrm{N})} \quad \frac{-\mathrm{Ca}}{(\mathrm{N})} \quad \frac{-\mathrm{D}}{(\mathrm{N})} \quad \frac{-\mathrm{Ca},-\mathrm{D}}{(\mathrm{N})}$

Treatment

Ovariectomized + Estrogen

Ovariectomized

8

12

8

Estrogen

8

12

8

Normal (no treatment)

8

8

8

8

8

8

8

8

\section{Analytical Methods}

Blood was obtained at the time of decapitation by exsanguination. Total calcium in serum was determined by atomic absorption spectrophotometry (AAS). The procedure followed was that of Fick et al. (1979). Data on serum calcium values are found in Appendix $\mathrm{E}$. 
Immediately after the animals were killed, uterine and vaginal tissues were removed, hind extremities were disarticulated at the acetabulum, and femurs were dissected free. The femurs were cleaned of adherent tissues. The uterine and vaginal tissues and femurs were fixed for 24 hours in $10 \%$ aqueous formalin.

Bone densitometric measurements ${ }^{1}$ using direct photon absorptiometry were made on one femur from each animal. Values of bone mineral content in grams per centimeter length of bone, linear bone density in grams per square centimeter, and bone length in centimeters were obtained. Appendix F contains information on these paremeters.

The same femurs were subjected to torque and deformation testing ${ }^{2}$ to determine the effect of treatment modality on these biomechanical properties. The procedure followed was that of Puhl et al. (1972). Explanation of this testing procedure is found in Appendix G.

Ashing of these same femurs was done as described by Fick et al. (1979). Appendix H contains data on ash analysis.

${ }^{1}$ Norland Digital Bone Densitometer, Model 278, Norland Corporation, Ft. Atkinson, WI 53538 .

${ }^{2}$ Rapid Load Torsional Testing Machine, Biomechanics Laboratory, Department of Mechanical Engineering, University of Florida, Gainesville, FL 32611. 


\section{Histology}

The alternate femurs of all animals were demineralized in a $10 \%$ solution of di-sodium-ethylene-diamine-tetracetic acid (EDTA) for a 7 to 14 day period. The solution was kept at $5^{\circ} \mathrm{F}$ with changes of solution every 2 to 3 days (Bélanger et al., 1965).

The demineralized femurs and vaginal tissues were dehydrated in $80 \%$ acetone for one-half hour and in $100 \%$ acetone for another half-hour. Clearing was accomplished with two changes of xylene ( 15 and 45 minutes); subsequently the tissues were embedded in paraffin. Medial sagittal sections of bone and cross sections of vaginal tissue were cut at $8 \mu \mathrm{m}$ in a microtome-cryostat, floated on water, slipped onto slides prepared with Haupt's solution, and air-dried.

Toluidine blue stain was chosen for mast cell quantitation purposes (Pathak and Goyal, 1973). With this stain, mast cells appear purple or reddish-purple against a general blue background. The slides were subjected to the following staining procedure:

(1) 2 changes of xylene (4 minutes each)

(2) acetone (several dips)

(3) water rinse

(4) $.2 \%$ toluidine blue

(5) water rinse

(6) acetone (several dips)

(7) 2 changes of xylene (4 minutes each) 
Alternate slides were stained with $.1 \%$ alcian blue in 3\% acetic acid for thirty minutes followed by a water rinse and $.1 \%$ safranin in $1 \%$ acetic acid for five minutes in place of step \#4 (Spicer, 1960). Using this staining procedure, the maturity of mast cells can be determined. Analysis of these slides is planned for a future time.

After air-drying, cover slips were applied to the slides with mounting medium.

Mast cells were counted in vaginal tissue and in the distal part of the femoral metaphysis and in the bone marrow of the diaphysis. Care was taken to avoid bone trabeculae and sinuses. Counts were made over five fields in each of five sections (25 fields per rat) for each type tissue at a magnification of $\mathrm{x} 400^{1}$ Each field measured $.458 \mathrm{~mm}$ in diameter, representing a surface area of $.165 \mathrm{~mm}^{2}$ and a total surface area of $4.1 \mathrm{~mm}^{2}$ for each tissue per rat. Counts were adjusted to $1 \mathrm{~mm}^{2}$ surface area. Appendix I contains mast cell quantitation data.

\section{Data Analysis}

The statistical evaluations for tests of significance were carried out on the parameters using analysis of variance and applying the $t$ test (Steel and Torrie, 1960). The tables list mean values and standard error of the mean $(S E=s / \sqrt{n})$, and indicate level of significance.

\footnotetext{
Iabophot-Laboratory \& Clinical Microscope, Nikon Instrument Division, 623 Stewart Ave, Garden City, NY 11530.
} 
Effects of diet were determined statistically by comparing the means in each deficient diet group with means in the normal diet group for each treatment.

Effects of treatment were determined statistically by comparing means for each treatment with the mean of the untreated rats within each diet group. 


\section{CHAPTER IV \\ RESULTS AND DISCUSSION}

The experimental animals used in this investigation were at least three months old at termination of the experiment and regarded as young adults. Reproductive capability was determined prior to treatments by vaginal cell sampling. One-half the population underwent ovariectomy, thereby removing the source of estrogen production.

The diet used for the vitamin D-deficient group of rats was also notably deficient in phosphorus, with a calcium to phosphorus ratio of 4.2 to 1 . Calcium to phosphorus ratios of all the diets are given in Appendix D.

As a matter of information, the calcium content of the complete diet (normal diet group) was $11.5 \mathrm{~g} / \mathrm{kg}$ and the phosphorus content was $10.1 \mathrm{~g} / \mathrm{kg}$. The calcium-deficient diet contained $1.6 \mathrm{~g} / \mathrm{kg}$ calcium and $26.6 \mathrm{~g} / \mathrm{kg}$ phosphorus. The rachitogenic vitamin D-deficient diet noted as being low in phosphorus contained $12.4 \mathrm{~g} / \mathrm{kg}$ calcium and $2.9 \mathrm{~g} / \mathrm{kg}$ phosphorus. The calcium- and vitamin D-deficient diet contained $1.6 \mathrm{~g} / \mathrm{kg}$ calcium and $26.6 \mathrm{~g} / \mathrm{kg}$ phosphorus (identical to the calcium-deficient diet but with omission of vitamin $D_{3}$ ). In addition, the protein in the vitamin D-deficient diet provided by whole yellow maize and as gluten, was of poor quality, lacking in essential amino acids. Therefore, 
when evaluating effects of this diet, the deficiency in protein and phosphorus must also be considered. Effects of diet were not due solely to lack of vitamin D.

\section{Body Weights}

Body weight changes were observed in the rats. In Table IV. 1 is recorded the average weight gain for each cell. The 8 weight gain is listed below the mean. The untreated rats fed a normal diet, and used as a control group, increased their body weight by 348 during the experiment. Lower weight gains were observed as due to calcium deficiency $(P<.05)$. The vitamin $D$-deficient group also had lower weight gains as an effect of diet $(P<.01)$. Administration of estrogen to both intact and ovariectomized rats decreased body weight gains in the normal, calcium-deficient, and the calcium- and vitamin D-deficient groups $(P<.05$ to .005$)$. Similar effects occured with rats on a normal diet (Cruess and Hong, 1979).

Ovariectomy increased the weight gains in the same three dietary groups ( $P<.005)$ (Fig. IV.1).

This supports the findings of Cruess and Hong (1979) and Lindgren and Lindholm (1979) in that removal of ovaries subjected rats to high increases in body weight. This effect has been associated with a higher food intake (Aitken et al., 1972). However, significant decreases in body weight of young castrated male rats have been observed (Scow, 1952; Gumbreck, 1957; Saville, 1969; Wink and Felts, $1980)$. 


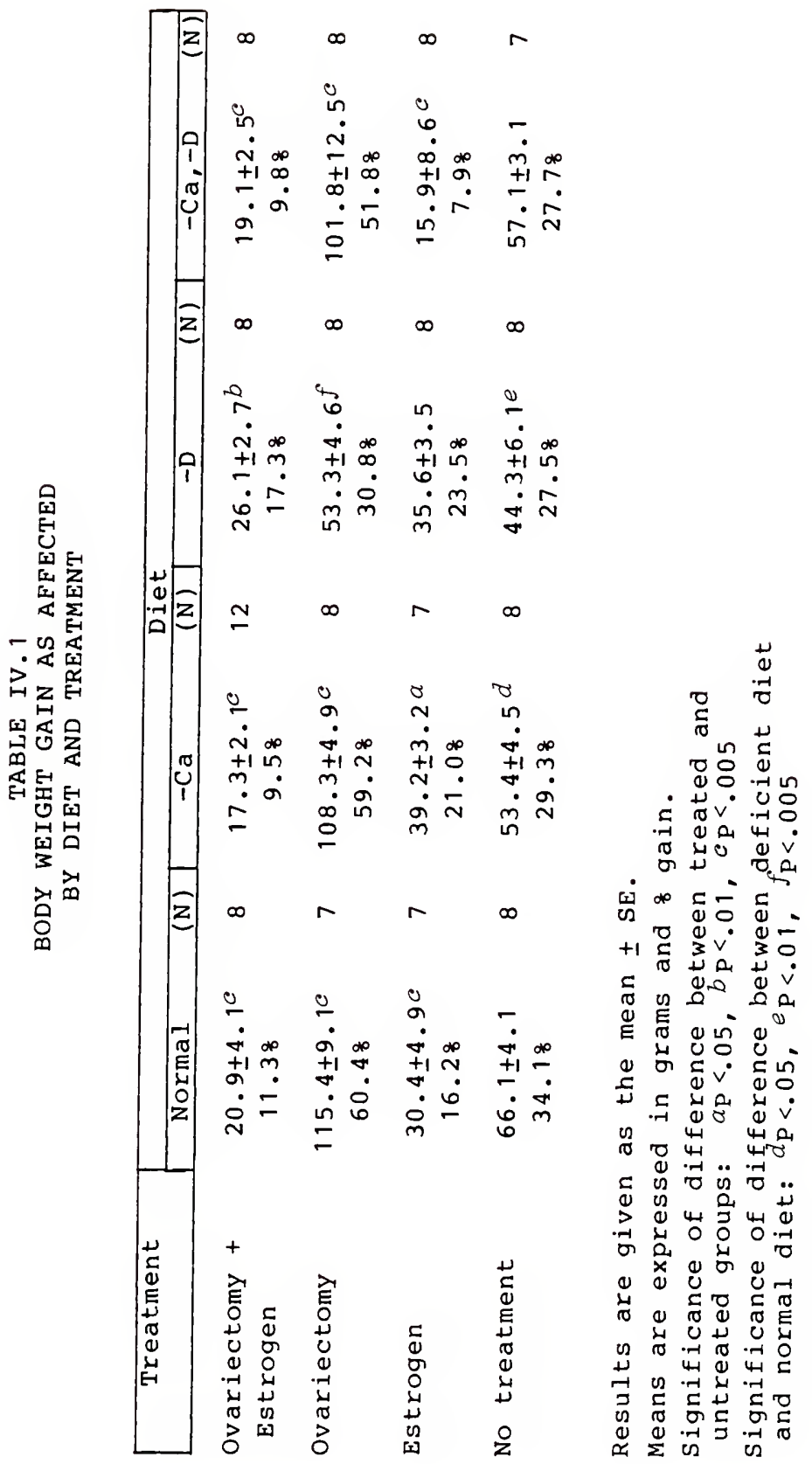




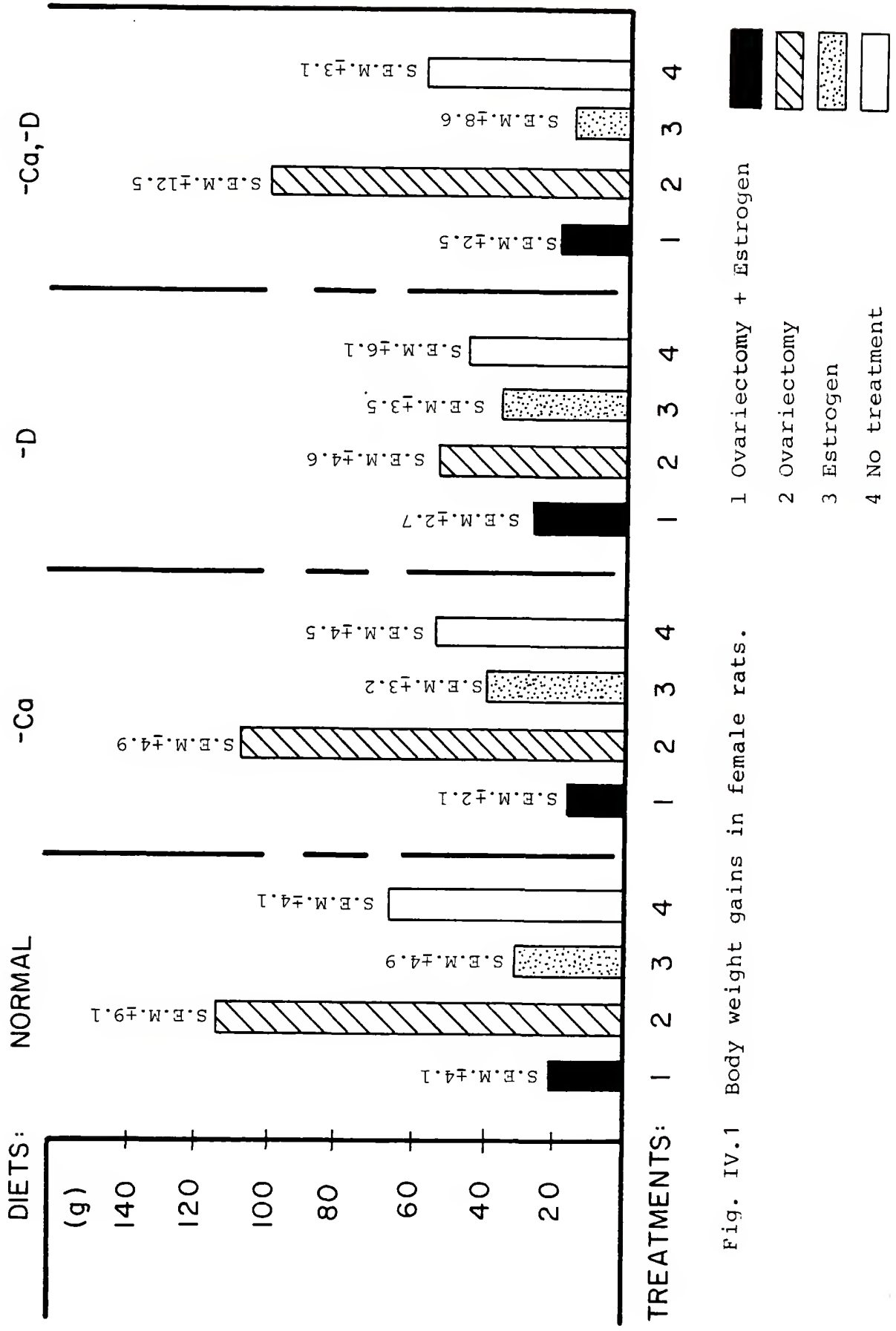


Results indicate a gain of weight in all cells of the study. A calcium-deficient diet and a combination protein, phosphorus, and vitamin D-deficient diet caused rats to gain less weight.

Estrogen inhibited the rate of weight gain, which is an effect not well understood. This effect was seen with both intact and ovariectomized rats. Ovariectomy clearly increased weight gain and estrogen administration reduced that gain to below the normal gain. The same pattern of this hormonal effect was observed in the deficient diet groups.

\section{Serum Calcium}

Table IV. 2 out.lines the changes in serum calcium observed in rats on four diet regimes and four treatments. Untreated rats on a normal diet had a mean serum calcium of $9.63 \mathrm{mg} / 100 \mathrm{ml}$. Rats on deficient diets which had been given estrogen had significantly lower serum calcium $(P<.01$ to .0005) than normally fed rats given estrogen. Rockoff and Armstrong (1970) and Feik and Storey (1979) also observed significant decreases in serum calcium with untreated, calcium- and vitamin D-deficient rats $(P<.1$ to $.01)$.

Estrogen increased the serum calcium in the intact and ovariectomized, normally fed rats $(P<.01$ to .001$)$ on the present study. Cruess and Hong (1979) found no consistent change in serum calcium concentration when estrogen was administered to intact, normally fed female rats over a 12 month period, but observed significant increases at one and six months $(P<.05)$. 


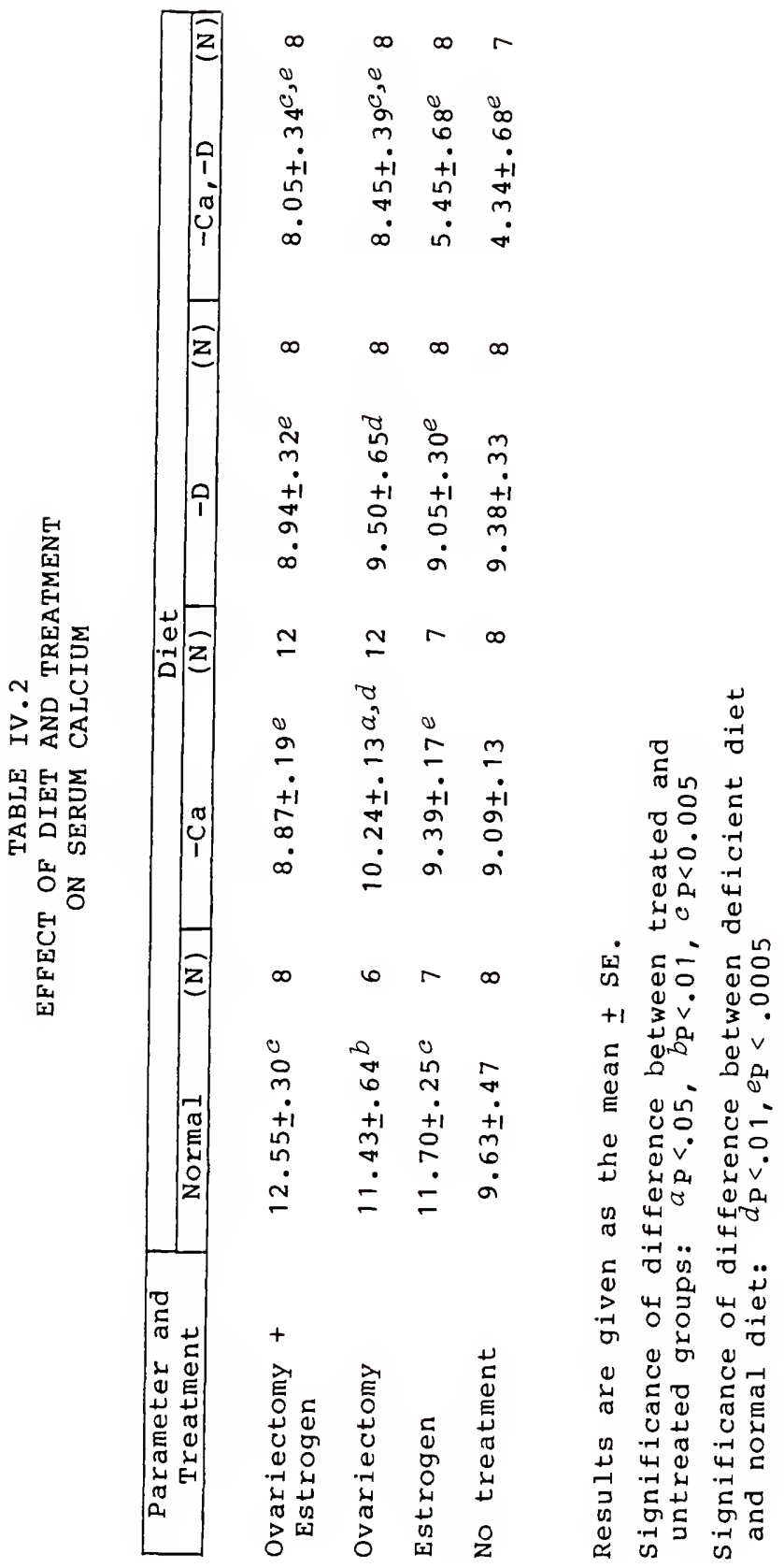


Ovariectomy significantly increased serum calcium in all dietary groups $(P<.05$ to .001$)$ except in the vitamin D-deficient group. Lindgren and Lindholm (1979) did not observe an increase in serum calcium in normally fed, ovariectomized rats. Others (Cruess and Hong, 1979) found ovariectomy to significantly decrease the serum calcium $(\mathrm{P}<.05)$

Results indicate that calcium- and vitamin D-deficient diets including deficiencies in phosphorus and protein may not have an effect on calcium concentration in the blood. The rat may compensate for lack of dietary nutrients by bone resorption of calcium and phosphorus to maintain normal blood calcium levels. Evidence for bone resorption was found in lower bone mineral content and lower ash values in rats deficient in calcium and vitamin D in the present study (Tables IV. 3 and IV.5).

Estrogen increased serum calcium in normally fed intact and ovariectomized rats. However, because of conflicting findings in the several studies mentioned, no firm conclusions can be made on the effect of estrogen on serum calcium in normal rats.

Ovariectomy effects on serum calcium have also been noted to vary among studies so that no conclusions can be made. Unknown factors may be influencing these two treatments, which causes findings to be inconsistent. 
Bone Densitometry

Femur lengths. Statistically significant differences in femur lengths due to diet and to treatments were observed. Values are found in Table IV.3.

The bone lengths of the normally fed rats were significantly longer than those of calcium-deficient and calciumand vitamin $D$-deficient rats in all treatment groups $(P<.05$ to .005).

Estrogen administered to intact and ovariectomized rats reduced bone length in the normally fed group and the calcium- and vitamin D-deficient group ( $P<.05$ to .005$)$.

Ovariectomy increased femur lengths in the normally fed group $(P<.05)$. Lindgren and Lindholm (1979) found femur length unaffected by oophorectomy. The sensitive photonabsorption method (Norland, 1980) used in the present study may have been responsible for detecting length differences.

Deficient diets used in this study clearly bring about a decrease in femur length in female rats during the growth period.

Estrogen tends to cause a shorter bone length, especially in normally fed rats and rats both calcium- and vitamin D-deficient. It is thought that estrogen causes the epiphyses to close prematurely which results in a shorter bone. Use of estrogen in young human females has this effect.

Confirming evidence of the preceding is observed in Fig. IV.2. Ovariectomy, or absence of estrogen, caused bone 


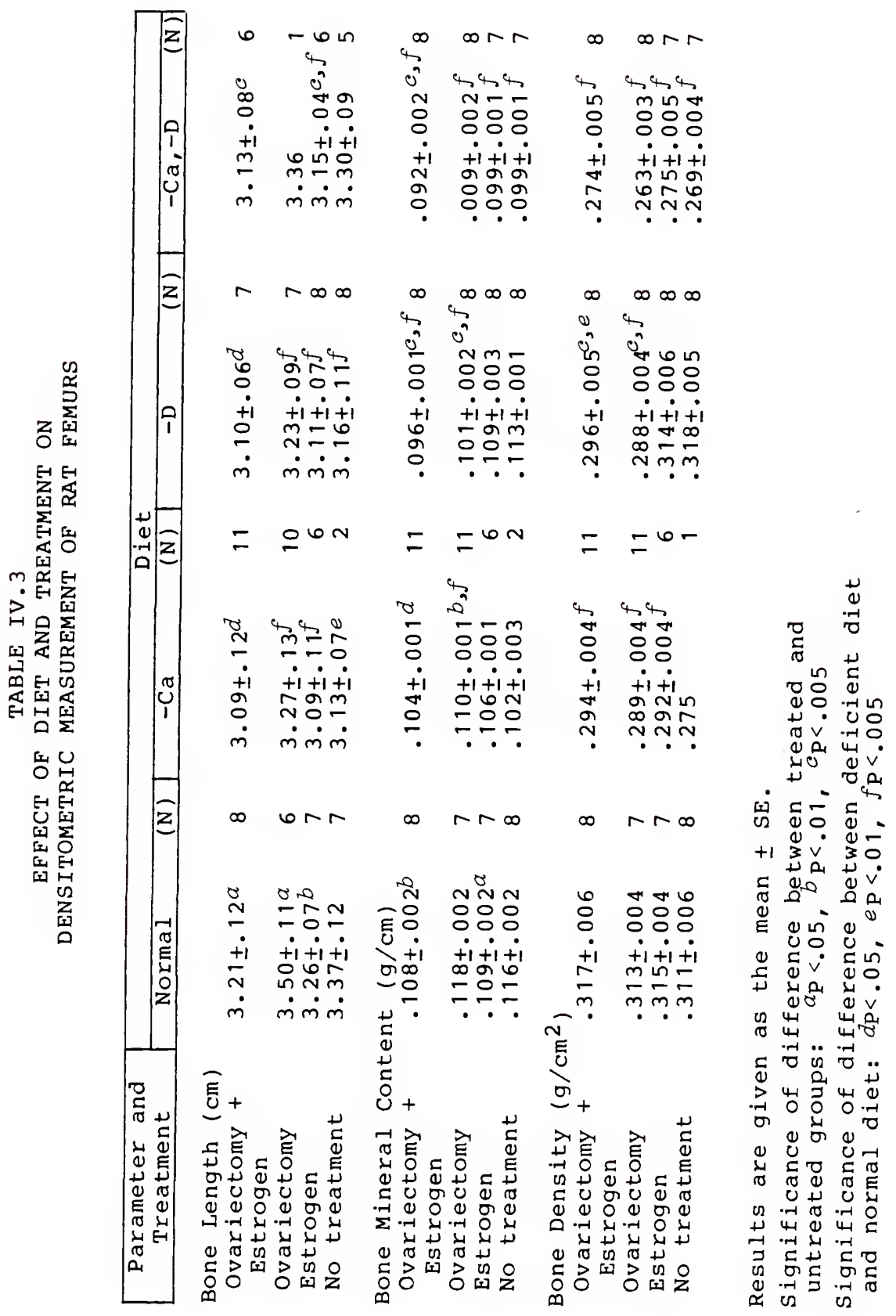




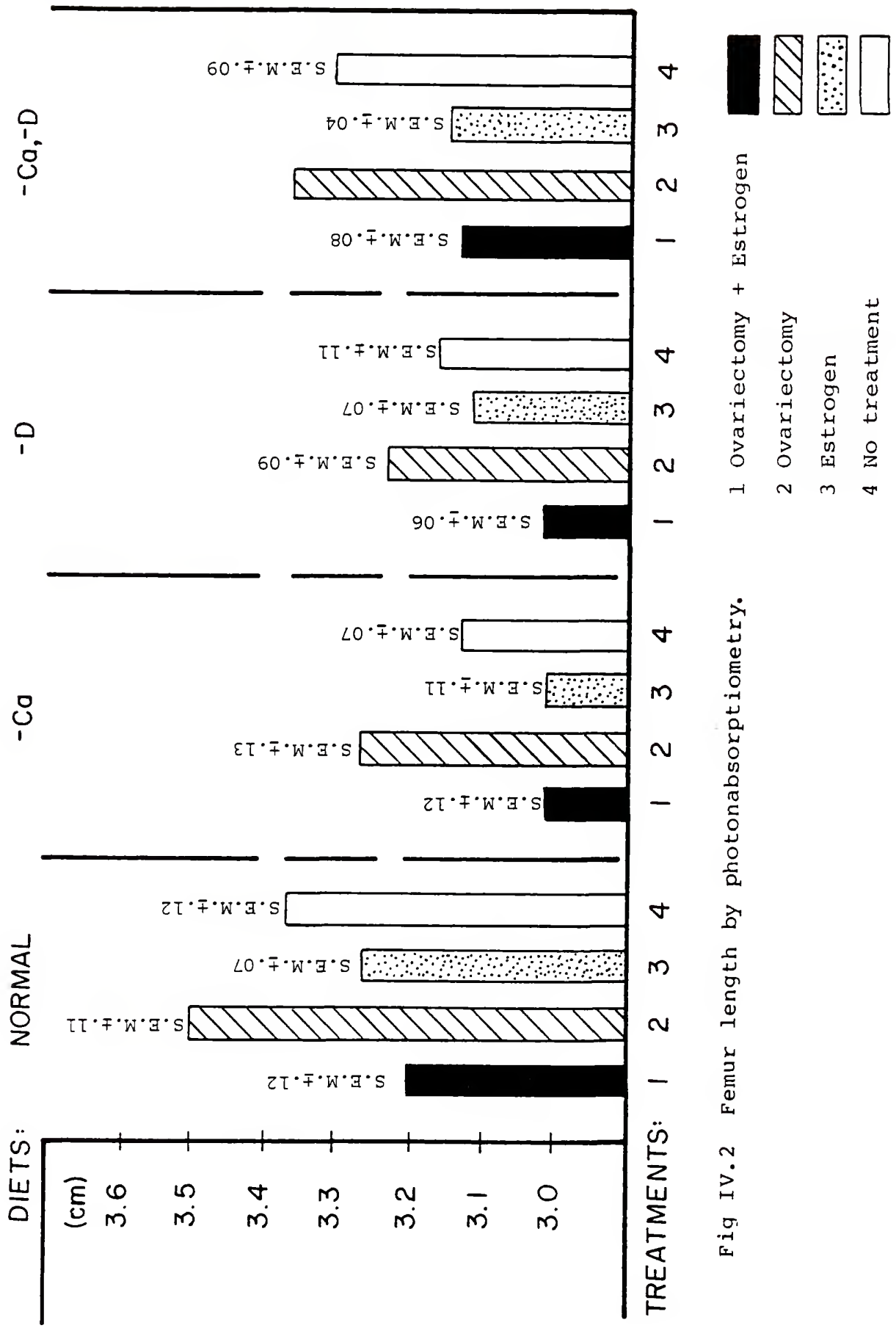


lengths to increase in normal rats. Addition of estrogen depressed bone length to normal or below normal.

Bone mineral content. Means and standard errors of the mean for mineral content of the femur as measured by the photonabsorption method (Norland, 1980) are listed in Table IV.3. Statistically significant differences in mineral content of the femur due to dietary deficiencies and to treatments were found. The calcium-deficient diet and the vitamin D-deficient diet lowered bone mineral content $(\mathrm{P}<.005)$

When administered estrogen, the normally fed intact rats had decreased bone mineral content $(P<.05)$ but other dietary groups showed no effect from estrogen.

Ovariectomy caused a higher bone mineral content in calcium-deficient rats $(P<.01)$, and a lower bone mineral content in vitamin D-deficient rats (P.<005); the latter effect most probably was due to the multiple deficiencies of the diet.

When rats were ovariectomized and estrogen was added, bone mineral content decreased in the normally fed group $(P<.01)$, and in both the vitamin $D$ and calcium- and vitamin D-deficient groups $(P<.005)$.

The results indicate that diet does cause decreases in bone mineral content in the female rat. When the rat is depleted of certain nutrients, osteopenia results. That the rat is a suitable model for this premise has been established by this and other studies. Extrapolation of the 


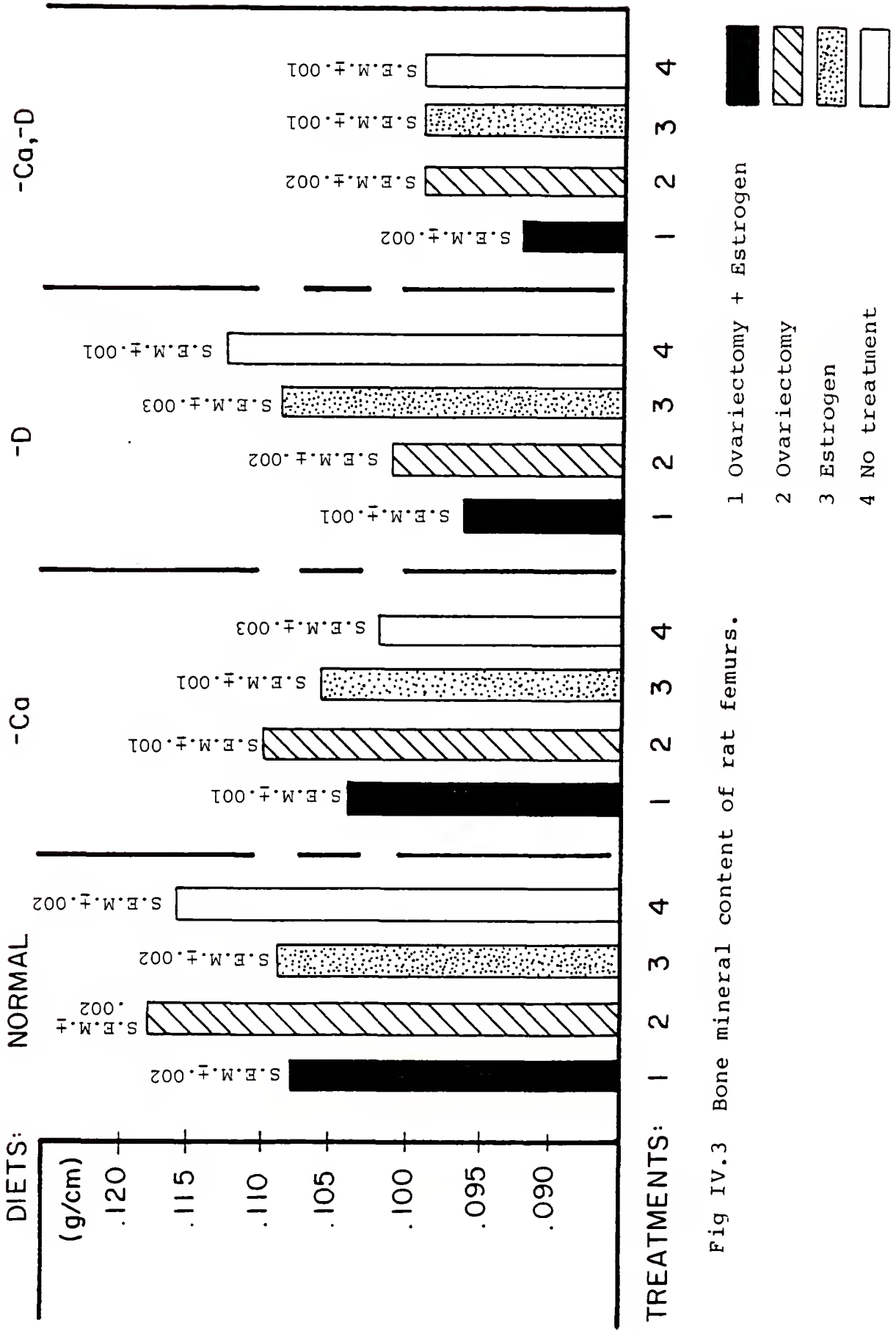


conclusion to the human female is difficult, however, the corollary does exist.

Sanchez et al. (1981) measured bone mineral mass in vivo in normally fed, untreated rats with a Norland-Cameron model 178 bone mineral analyzer. They found highly significant positive correlations between femoral mineral mass, femoral ash weight, and body weights. Similar statistical correlation tests are planned for the data in the present study.

Bone density. The bone density measurement is a ratio of the bone mineral content and the femur width, so that differences between bone mineral content and bone density were due to bone width and did not vary with bone mineral content, since the measurements were done simultaneously.

The means and standard errors of the means for bone density values are found in Table IV. 3.

Dietary deficiencies signficantly decreased bone density in several treated and untreated groups $(P<.05$ to $.005)$. Calcium- and vitamin D-deficiency especially affected density $(P<.005)$ (Fig. IV.4). Only one intact femoral bone from untreated calcium-deficient rats was available; therefore it was not used for statistical comparisons.

Estrogen treatment showed no effect on bone density, whether given to intact or ovariectomized rats. 


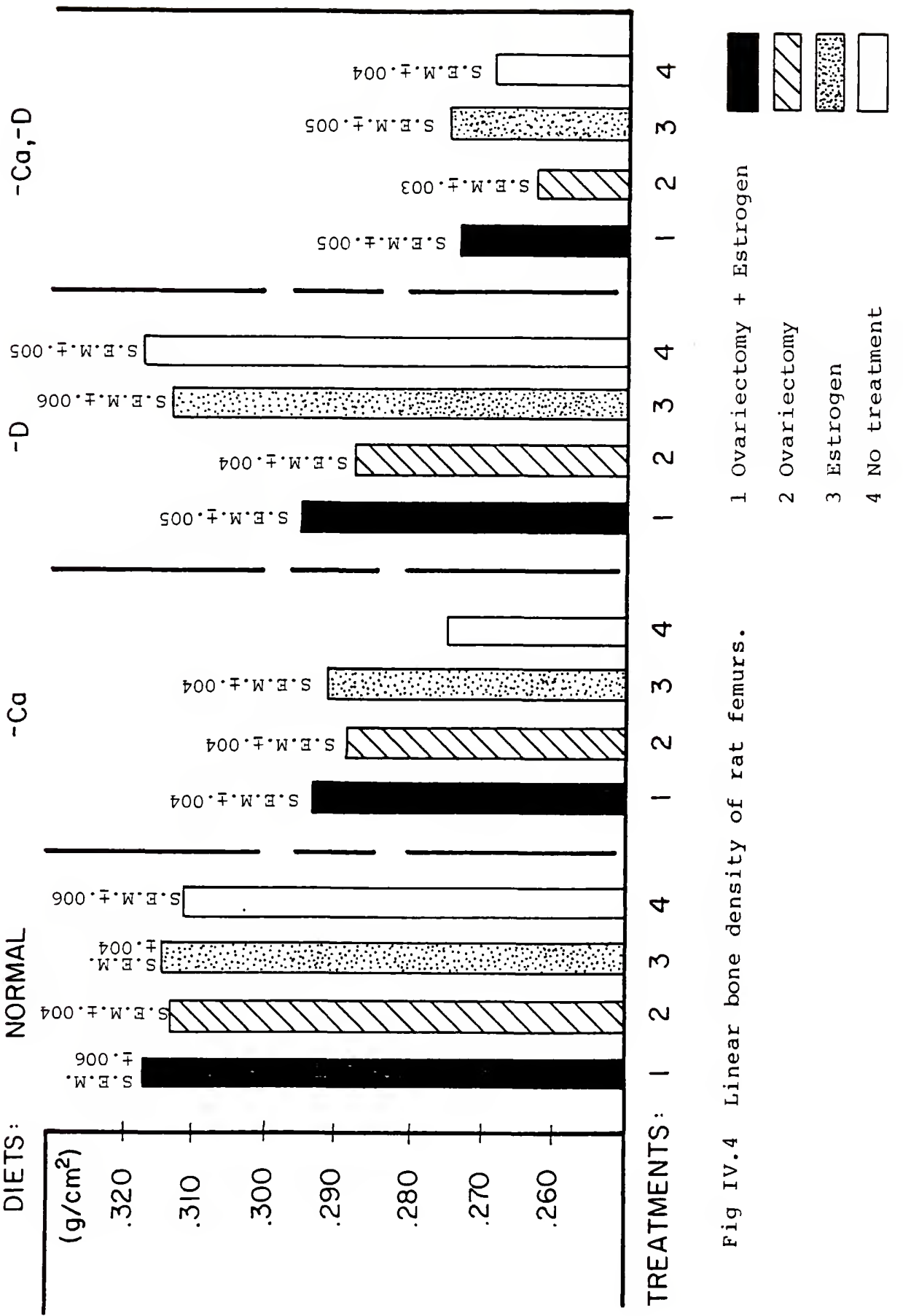


Ovariectomy also did not affect bone density. However, within the vitamin D deficient group, which also was deficient in protein and phosphorus, bone density was decreased by estrogen and by ovariectomy $(P<.005)$.

Burkhart and Beresford (1978) castrated 1 1/2-year-old male rats and reported decreased femoral density 3 to 6 months later. A Joyce-Loebel photodensitometer was used to measure the density. Wink and Felts (1980) also reported density decreases in male castrates $(P<.01)$ and femoral osteoporosis four months after castration in year-old male rats.

\section{Biomechanical Tests}

Table IV.4 lists the mean and standard errors of the torque required to fracture the femurs and of the deformation undergone by the bones at fracture.

Torque. In all treatments, the calcium-deficient group and the vitamin $D$-deficient group required the least torque $(P<.01)$ for fracture to occur (Fig. IV.5).

Estrogen administered to intact rats significantly lowered torque in the normally fed group $(P<.05)$ and raised it in the vitamin $D$-deficient group $(P<.05)$.

Ovariectomy decreased the torque value significantly in the calcium- and vitamin D-deficient group $(P<.05)$.

When estrogen was given to ovariectomied rats, torque values were reduced significantly in the normally fed group $(P<.05)$ and raised significantly in the calcium-deficient group $(P<.05)$. 


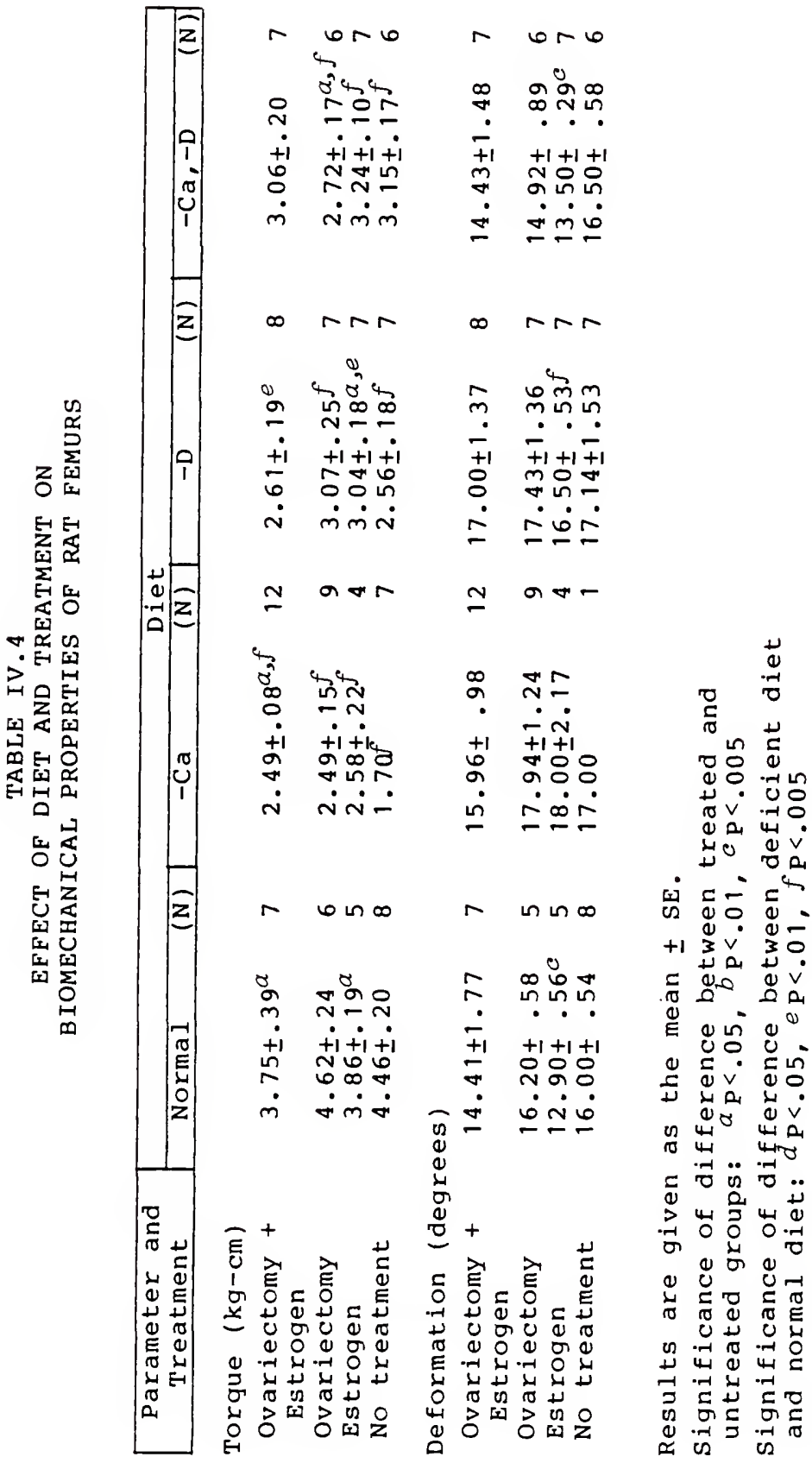




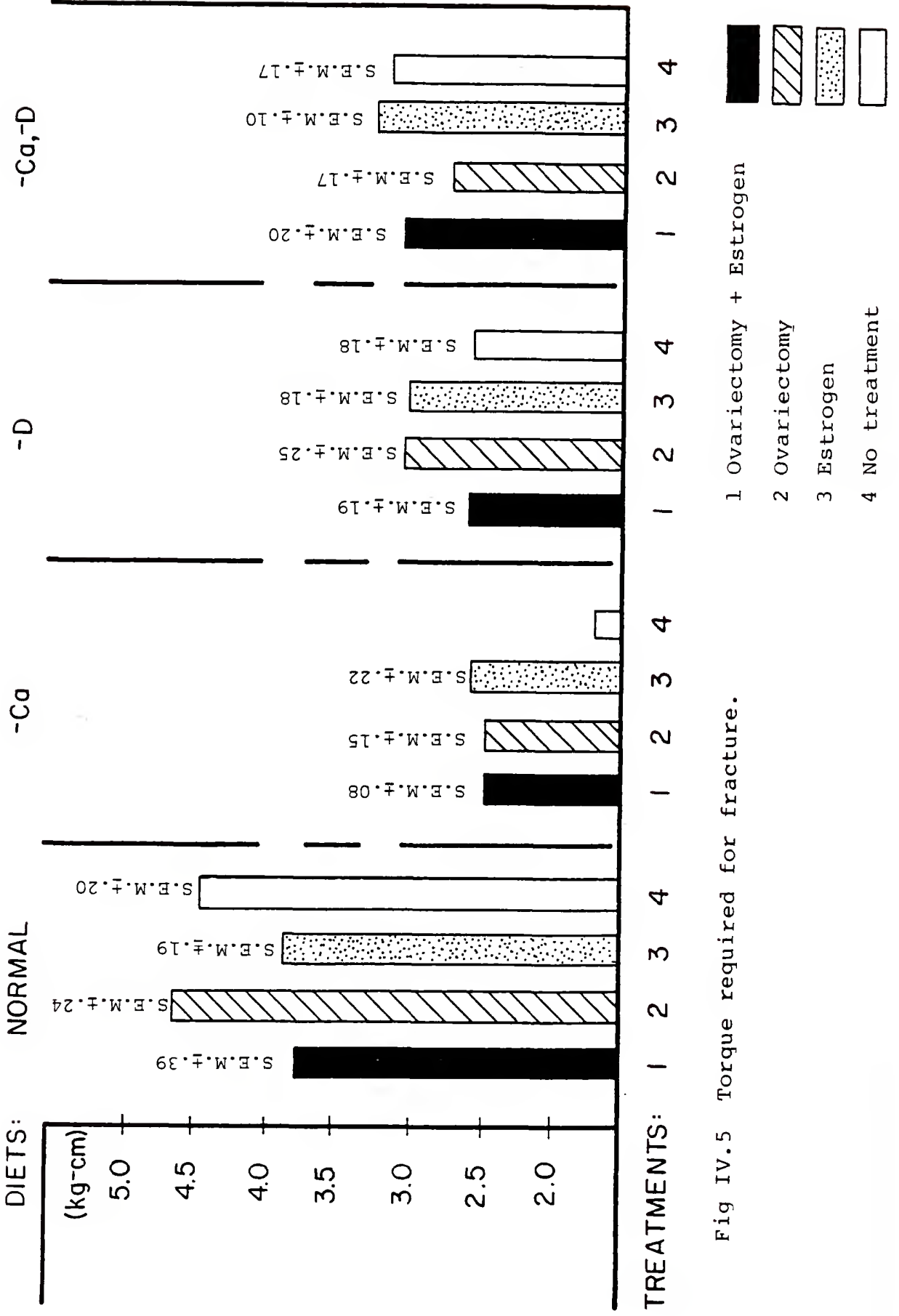


Deformation. Dietary deficiencies had no effect on deformation of the rat femurs.

When estrogen was administered to intact rats in each group, the normally fed group and the calcium- and vitamin D-deficient group showed significant decreases in deformation values $(P<.005)$. This effect can be interpreted to mean a harder bone with less bending ability resulting from estrogen administration.

Ovariectomy did not affect deformation of the femurs in any group.

Fig IV. 6 represents the femoral deformation values for the rats in the study.

\section{Bone Ash}

Values for bone ash as of of dry, fat-free femoral bone are listed as means $\pm S E$ in Table IV.5. Differences in bone ash content between rats on deficient diets and those adequately fed were statistically significant in all treatments $(\mathrm{P}<.01)$, with highest values in the adequately fed group. Decreases in skeletal ash weight of rats on calcium-deficient diets have been previously observed $(P<.001)$ (Rockoff and Armstrong, 1970).

Estrogen administration did not alter bone ash in any dietary group, however, ovariectomy decreased of ash content in the calcium-deficient group. The effect of ovariectomy and estrogen was an increase in bone ash in vitamin D-deficient and calcium- and vitamin D-deficient groups $(P<.05)$. 


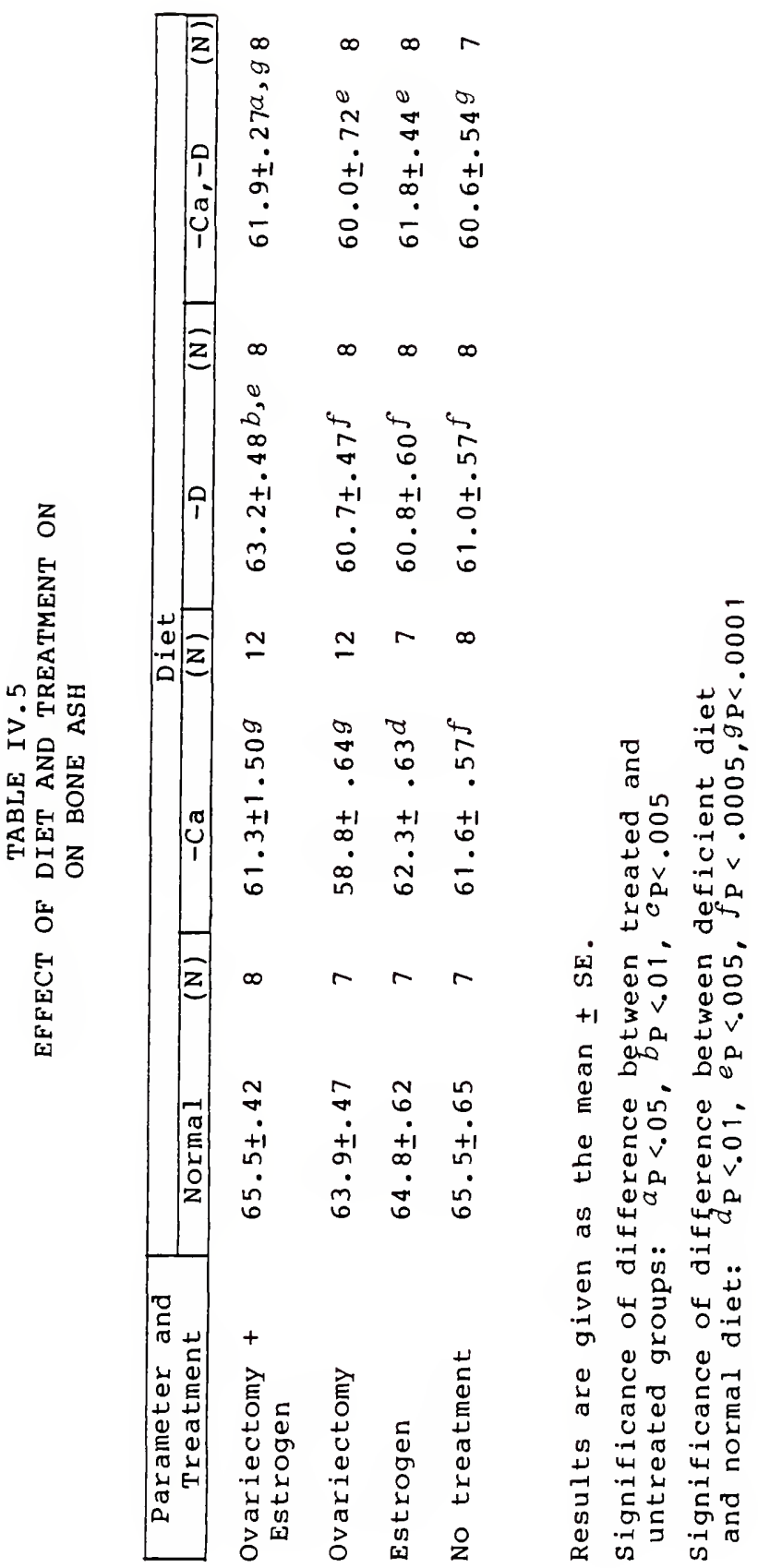




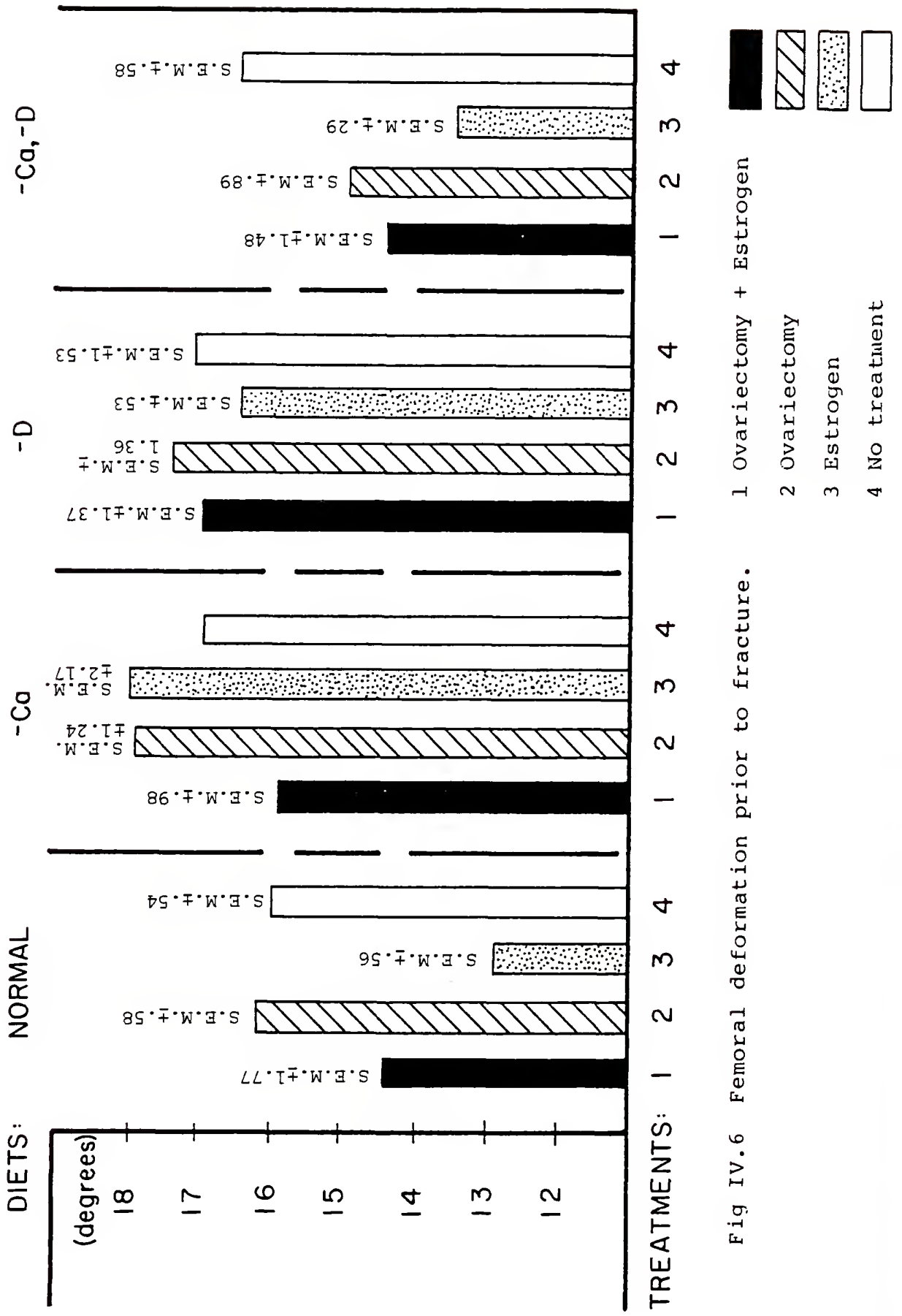


Other normally fed animals have shown no alteration in ash content of bones after estrogen administration, but oophorectomy caused a significant decrease $(\mathrm{P}<.05)$ in ash content which was reversed by estrogen $(P<.05)$ (Cruess and Hong, 1979). Other significant decreases in ash weight as of of femur dry weight have also been reported with oophorectomy $(P<.01)$, even though the rats also had a high body weight gain $(P<.05)$ (Lindgren and Lindholm, 1979). By castrating male rats and maintaining a normal diet, a decrease in 8 ash was observed after 3 to 6 months (Burkhart and Beresford, 1978; Wink and Felts, 1980). It is probable that a longer period than one month must be observed post ovariectomy in order to detect significant differences in bone ash in rats on a normal diet.

\section{Mast Cells}

\section{Bone Marrow Mast Cells.}

Means of mast cell counts in the distal metaphyseal and diaphyseal portions of the femoral bone marrow are presented in Table IV.6. Means for each group were obtained and adjusted to an area of $1 \mathrm{~mm}^{2}$. The range of mast cell counts is also given as counts per $1 \mathrm{~mm}^{2}$ surface area. Appendix I contains photomicrographs of bone marrow mast cells (Fig I.1-I.4). Figure IV.7 provides a visual representation of bone marrow mast cell populations observed in this study. 


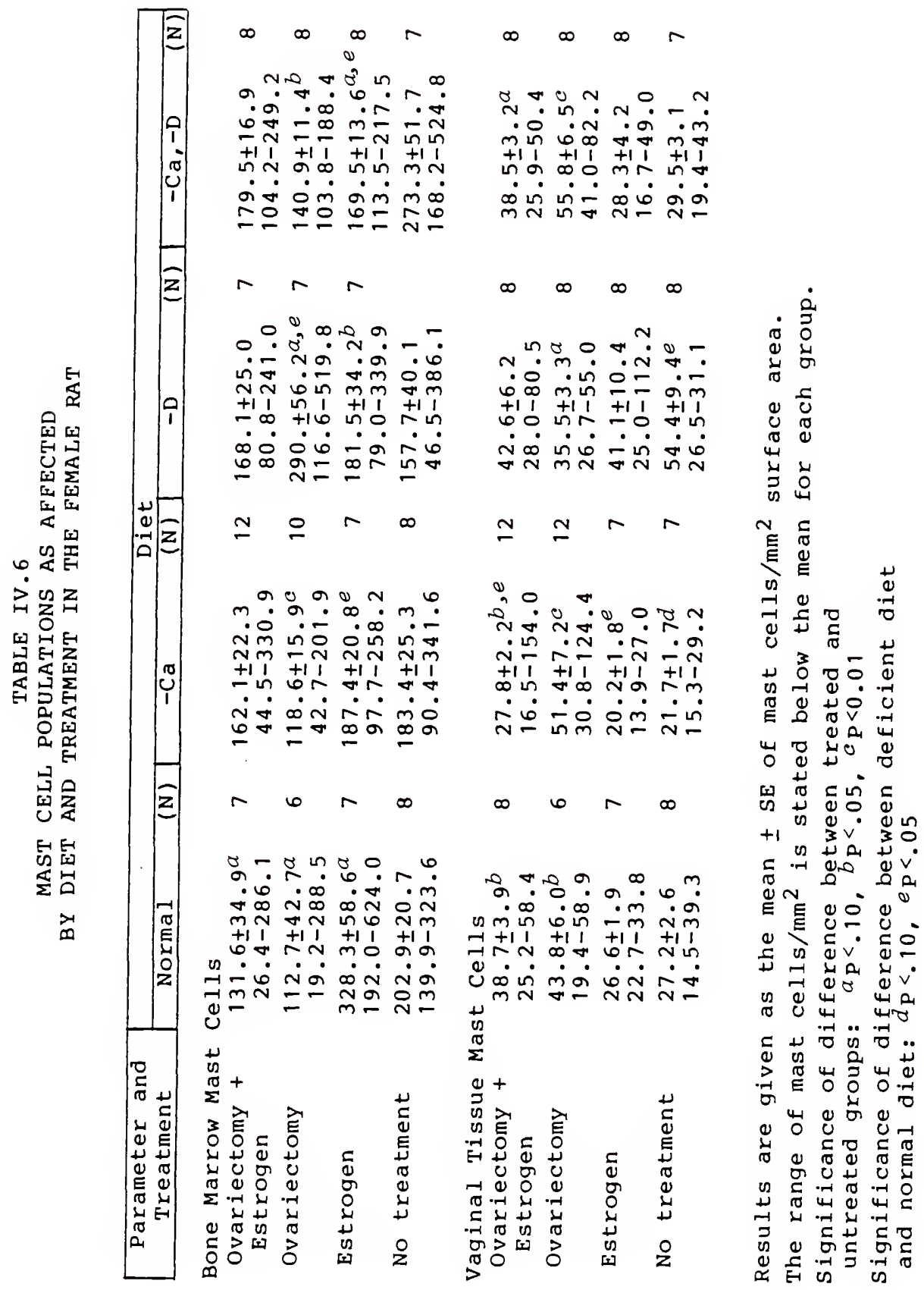




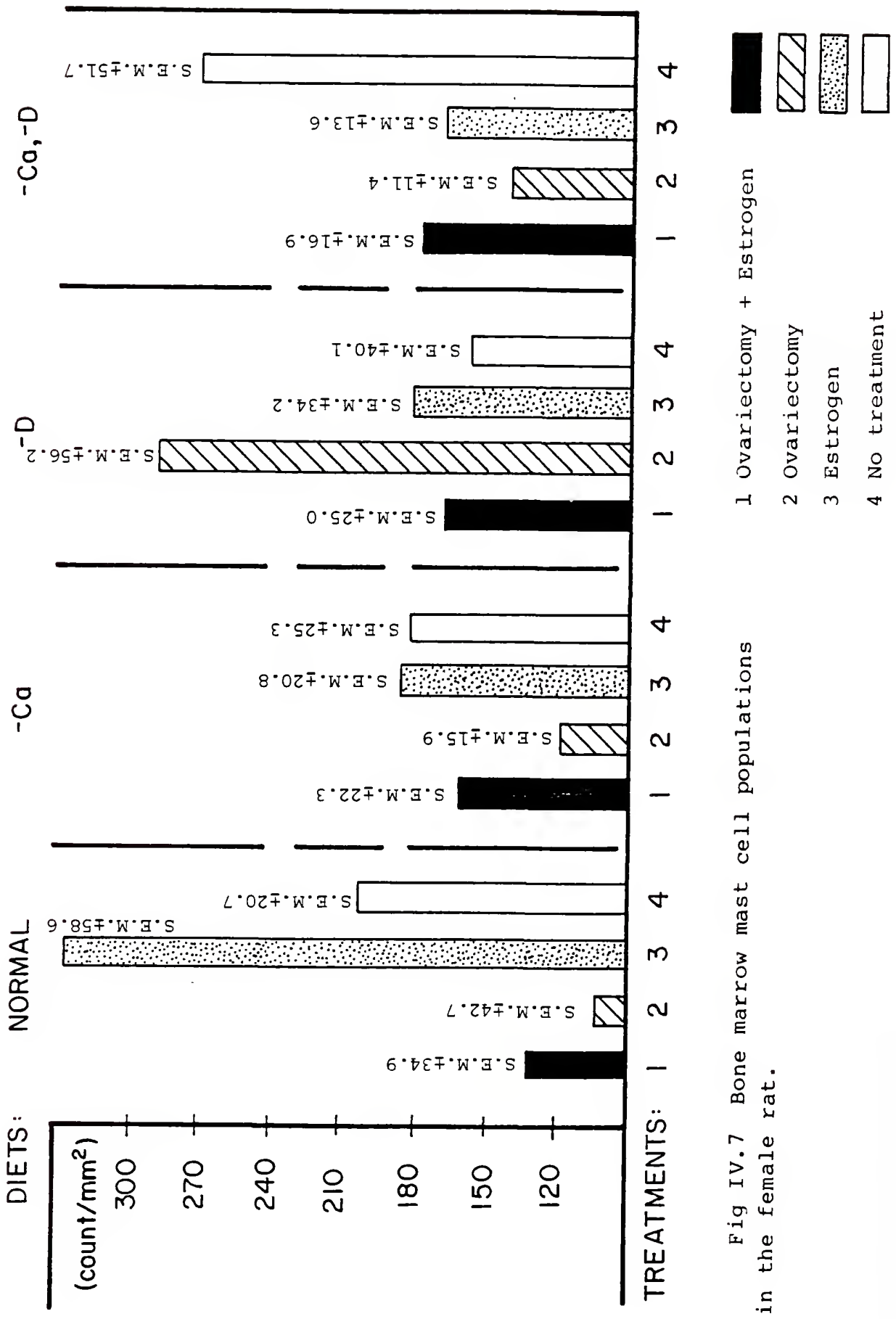


Normal diet group. The mean number of mast cells per $\mathrm{mm}^{2}$ in the bone marrow of these normal, untreated young rats was 202.9 \pm 20.7 . Bélanger (1977) recorded mast cell populations of $123 \pm 16$ per $\mathrm{mm}^{2}$ bone marrow in normally fed rats.

Estrogen increased the count in normally fed, intact rats $(P<.10)$ (Fig. IV.7). Bélanger (1977) found no change in count when estrogen was used in rats on normal diets.

Ovariectomy produced a decrease in mast cell count $(P<.10)$. When estrogen was given to ovariectomized rats, the count continued to remain below that of the untreated rat $(P<.10)$.

Calcium-deficient group. The calcium-deficient, untreated rats in this study showed no change in bone marrow mast cell count from that of the adequately fed rats. This finding was somewhat surprising. The well-known study by Urist and McLean (1957) describes extensive increases in calcium-deficient rat bone marrow. However, no statistical evidence was reported. Their rats were weaned at three weeks to a calcium-deficient diet, whereas the rats on this study began the deficient diet at two months of age. Greatest increases in mast cell counts in their rats were reported as occurring after six to 15 weeks. The rats on the present study were fed a calcium-deficient diet for only six weeks. Rockoff and Armstrong (1970) also experienced marked mast cell hyperplasia in calcium-deficient rats. However, 
mean number per field and distribution of cells in calciumdeficient rats did not vary from the normally fed rats in the study of Rasmussen (1972). It may well be that age of rat and duration of calcium deficiency play an important role in mast cell population changes, if alterations do, in fact, occur.

In contrast to normally fed animals, calcium-deficient rats administered estrogen did not show altered counts. However, calcium-deficient, estrogen treated rats did show increased counts when compared to normally fed, estrogen treated rats $(P<.05)$.

Ovariectomy produced a significantly decreased mast cell count in this group $(P<.01)$.

Vitamin D-deficient group. A combined lack of protein, phosphorus, and vitamin $D$ produced no changes in bone marrow mast cell count in the untreated animals. Estrogen significantly increased the marrow count in the intact rats $(P<.05)$ and ovariectomy also increased the count $(P<\cdot 10)$. Ovariectomized rats also had an increased bone marrow mast cell count when compared to ovariectomized, normally fed rats $(P<.05)$ indicating an effect of diet.

Contrary to the above finding, Rasmussen (1972) reported marrow mast cells in a vitamin D-deficient group to be higher than those of normally fed rats. The statistical significance level was not given.

Calcium- and vitamin D-deficient group. Effect of diet in untreated rats in this group was not observed. Rasmussen 
(1972) reported significantly higher numbers of marrow mast cells per field in a calcium- and vitamin D-deficient group when compared with a normally fed group.

In the present study, when rats in this dietary group were treated with estrogen, the mast cell count decreased from that of the estrogen treated, normally fed group $(P<.05)$ and from the untreated rats in the same calcium- and vitamin $D$-deficient group $(P<.10)$ indicating an effect of diet and treatment.

Ovariectomy also caused a significant decrease in mast cell marrow count $(P<.05)$.

It has been suggested that mast cell increases in bone marrow are due to secondary hyperparathyroidism caused by hypocalcemia (Rasmussen, 1972). As was mentioned previously in the serum calcium section, dietary deficiencies did not consistently cause hypocalcemia in the present study nor in other studies. As stated, diet did not affect serum calcium or bone marrow mast cell numbers in the present study.

The rats given estrogen were made hypocalcemic in all deficient diet groups, but did not exhibit mast cell increases. The reverse was found with normally fed rats, i.e., an increased mast cell count was observed in estrogen treated rats with normal serum calcium levels. Hormone treatment may have interfered with the theory mentioned above, even though estrogen receptors are not known to occur in bone. 
A consistent decrease in marrow mast cell number was observed in calcium- and vitamin D-depleted, estrogen deficient rats (ovariectomized). With the addition of estrogen, marrow mast cell numbers were returned to the normal range. This finding clearly indicates the presence of hormonal activity in bone.

\section{Vaginal Tissue Mast Cells}

The mean number of mast cells per $\mathrm{mm}^{2}$ vaginal tissue in the different groups of rats is given in Table IV.5 and is illustrated graphically in Fig. IV.8. Photomicrographs of vaginal tissue mast cells observed in this study are contained in Appendix I (Fig. I.5-I.8).

Normal diet group. Vaginal mast cells in the untreated control group numbered $27.2 \pm 2.6$ with a range of 14.5 to 39.3. Estrogen given to intact rats in this group did not alter the count. However, ovariectomy did increase the count significantly $(P<.05)$. Estrogen given to ovariectomized rats, however, did not return the count to a normal range.

Estrogen given to intact mice increased vaginal mast cells substantially (Westin and Odeblad, 1956) again suggesting species difference; however, Johannson and Westin (1959) report estrogen as suppressing true mast cell numbers in mouse vaginal tissue. 


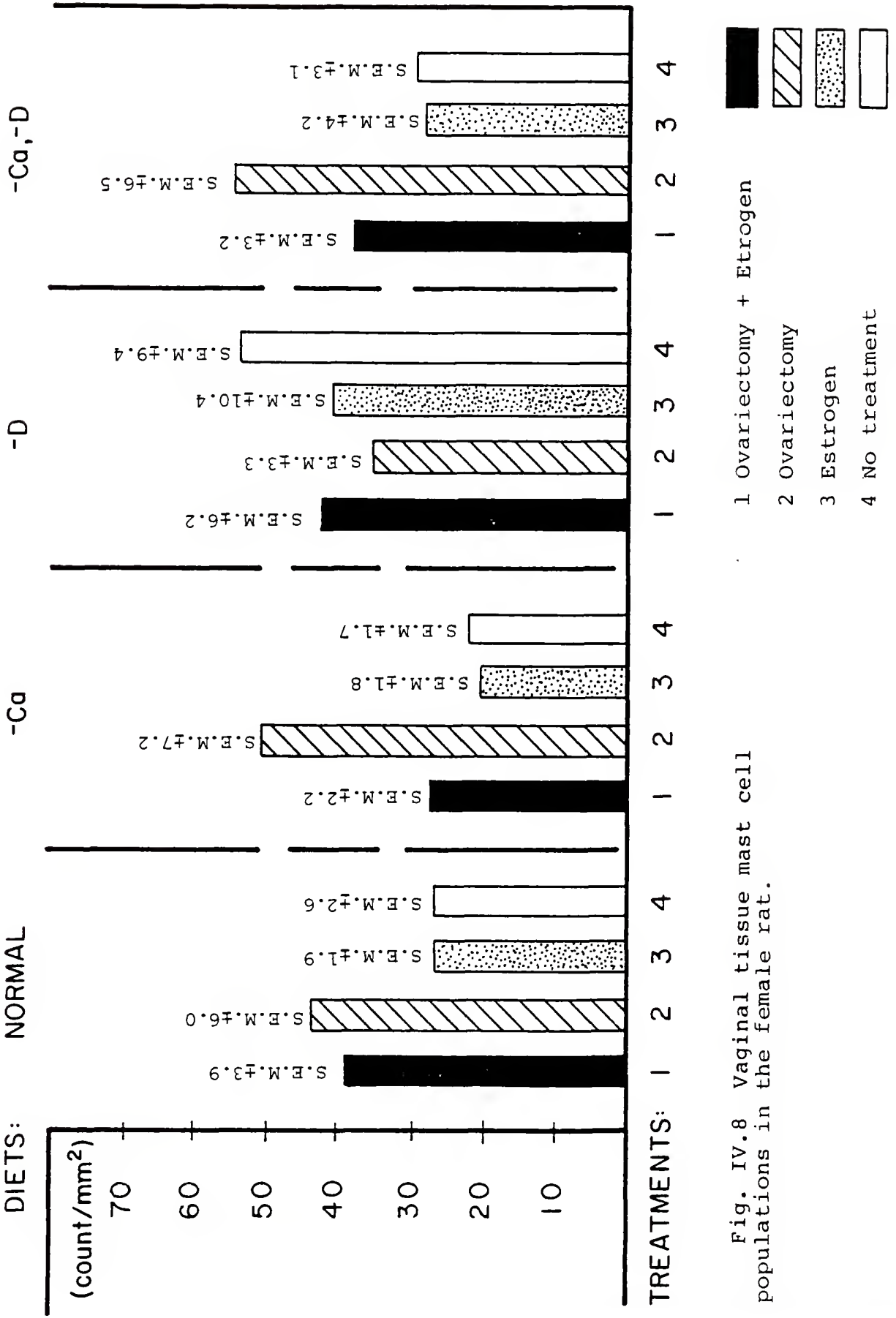


Calcium-deficient group. Calcium deficiency produced a decrease in the vaginal tissue mast cell count at the $P<.10$ level, indicating a very weak, almost non-existent effect.

Calcium deficiency also produced a decrease $(P<.01)$ in estrogen treated rats. Likewise, the deficient diet showed an effect of decreasing the mast cell count when these rats were ovariectomized and given estrogen (compared with normally fed rats of similar treatment $(P<.05)$.

Within the group, when compared with untreated rats, ovariectomized rats exhibited an increased vaginal tissue mast cell count $(P<.01)$. With the addition of estrogen, the cell count was reduced to the normal range of a calciumdeficient animal.

Vitamin D-deficient group. Untreated rats in this group had higher vaginal tissue mast cell counts than normally fed rats $(P<.05)$. Treated rats did not display an effect of diet deficiencies on mast cell numbers.

Estrogen did not alter mast cell counts; but lack of estrogen caused a reduction in number $(P<.10)$. These rats were given a diet deficient in protein and phosphorus as well as vitamin $D$; results would possibly be affected by the lack of those nutrients.

Calcium- and vitamin D-deficient group. Diet had no effect on mast cell count in this group.

Within the group, estrogen given to intact rats produced no changes in vaginal tissue mast cell counts. Ovariectomy, however, caused an increase in cell numbers $(\mathrm{P}<.01)$. 
Estrogen added to the ovariectomized rats maintained a count higher than normal for this group $(P<.10)$. Overall, mast cell counts in rat vaginal tissue were much less variable within groups than in bone marrow.

Summarizing the influence of diet and treatment on vaginal tissue mast cell populations, one observes that depletion of bone in the rat by dietary calcium deficiency, as evidenced by densitometric bone analysis and bone ash levels, has no effect on the vaginal tissue mast cell number. This is a finding which has not been supported by the literature since studies of vaginal tissue mast cells do not exist.

It is important to examine the pattern of hormonal effects. Estrogen given to intact rats did not affect mast cells in the vaginal epithelium, an estrogen sensitive tissue. But when the rats were deprived of estrogen by ovariectomy, mast cells increased above normal, irrespective of diet. When estrogen was added, the increased populations were maintained above normal, but a hormonal effect of reducing the numbers may be a possibility.

The vitamin D-deficient group does not fit this pattern, most probably because of the effects of additional dietary deficiencies. As an effect of this diet, however, mast cells did increase in vaginal tissue. With ovariectomy a decrease was observed. 


\section{CHAPTER V \\ CONCLUSIONS}

Change (reduction) in mast cell numbers in rats made osteopenic by dietary deficiencies of calcium and vitamin D as evaluated by bone densitometry and bone ash content was observed in vaginal tissue as an effect of a calcium-deficient diet at the $P<.10$ level of significance. Because of the weak evidence of mast cell reduction occurring, the first hypothesis is not proven. This finding is not documented in the literature as studies concerning mast cell populations in rat vaginal tissue do not exist.

Bone marrow mast cell populations did not vary as a result of dietary deficiencies. That significant changes in mast cell populations did not occur in the bone marrow was surprising because other studies have indicated a substantial increase in bone marrow mast cells with calcium deficiency and osteoporosis (Urist and McLean, 1957; Frame and Nixon, 1968; Rockoff and Armstrong, 1970; te Velde et al., $1978)$.

Two possible explanations for lack of change in marrow mast cell numbers are suggested. The rats in the present study were at least two months old before being fed deficient diets. It was desirable to have rats with estrous 
cycles in order to observe the effect of removing the circulating estrogen. The rats in the aforementioned studies were weanlings.

In addition, the duration of dietary deficiencies may have been too short to overcome the effect of age, even though osteopenia was indicated. The rats in the present study were kept on deficient diets for a period of five weeks which approximated .058 of their life span. With dietary deficiencies extended over a longer period of time, significant alterations in marrow mast cell numbers may have been seen.

The effects of exogenous estrogen were seen to reduce bone marrow mast cell numbers in rats both calcium and vitamin D deficient, which supports the second hypothesis of this study, in part. An opposite effect of estrogen administration was seen in normally fed rats: the bone marrow increased significantly in mast cells. This inconsistency is not understood. However, these results strongly suggest that bone is an estrogen sensitive tissue, even though estrogen receptors have not been found in bone.

Bilateral ovariectomy significantly affects both vaginal tissue and bone marrow with respect to mast cell populations. Removal of estrogen production in the rat reduces bone marrow mast cells in rats normally fed and also in those deficient in calcium and vitamin D. An opposite effect of estrogen removal is seen in the vaginal tissue. Both observations support the hypothesis that ovariectomy 
alters mast cell populations in bone marrow and vaginal tissue of calcium- and vitamin D-deficient rats.

In absolute terms, ovariectomized rats resupplied with estrogen demonstrated increases in vaginal tissue mast cells and a decrease in marrow mast cells. These are changes similar to those stated as an effect of ovariectomy alone. However, upon observing Figs. IV.7 and IV.8, one can detect that replacement of estrogen may be causing a reversal of mast cell population change due to ovariectomy. Statistical analyses between ovariectomized groups with and without estrogen will be performed in the near future to determine whether added estrogen changes mast cell populations in ovariectomized rats.

It is important to consider again the possibility that both age of the rat when begun on a deficient diet and duration of feeding a deficient diet may greatly influence mast cell populations in the two tissues examined in this study .

Ovariectomy, the procedure which removes the endogenous gonadal hormone supply has known consequences relating to bone loss in the human female. Whether mast cell changes similar to those in the rat occur in the human is not known. Considering the results of the present study, a quantitative investigation of mast cell populations in vaginal tissue of ovariectomized women may provide information useful in the study of osteopenia and bone resorption. 
It has also become apparent that qualitative investigation of the mast cell populations, including histologic bone evaluations, needs to be considered from data obtained in the present study. The need for further examination of correlations between bone densitometric measurements, bone ash, serum calcium, biomechanical tests and the mast cell populations is also immediate. Statistical analysis is scheduled for these parameters. 
APPENDIX A

SIGMA XI GRANT-IN-AID OF RESEARCH 


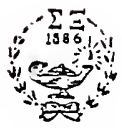

SIGMA $X I$

THE SCIENTIFIC RESEARCH SOCIETY OF NORTH AMERICA

For the Encoursgement of Scientific Research

\section{Grants-in-Aid of Research}

Grants-in-Aid of Research are supported by voluntur; contributions to the Rescarsit Program from the nembership of SIGilA XI. Awards are numally nale in amounts maging from $\$ 100$ (or less) to a maximum of $\$ 1.000$.

Research awards may be made to support scientufic investigation in any tield. Each award is made payable to the individual recipient. Vo gar: of a grint mily be used tor the payment of any indiret: costs to the recipient's institution-all of the tinds must be expended directly in support of the proposed investigation. All zquipment gurchised shu!l be the property of the institution. Giants rorinaly are rot male ior ex penses of publicution. salary or tuition. travel to metings. or usulal and coutire instituiuna! obligutions. Priority is usually given to upplicants who are in an aurly stage of their scientitic gerests.

The Commictee on Awards meets on or about the tirst of March. Juns. and December of each year and applicants are notitied of the Committe's jecisions vithin six weexs.

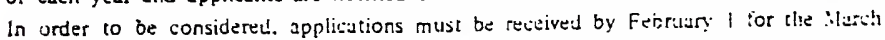
meeting, . Kay 1 for the June meetung. and Voveniver 1 for the Decenber meeting at Sisma Xi National Headquarters. $3+5$ Whitney dvenue. Naw Haven. Connect:cut U6511. Attention: Committee on Awards.

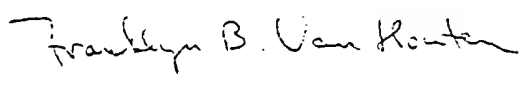

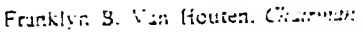


APPLICANT: Please fill in these three items only. APPLICANT : $\quad$ Tesar $\ldots \ldots$ Rogene $\ldots \ldots \ldots . . . . .$. LAST NAME FIRST NAME MIDDLE NAME

FIELD: . Nutrition and Osteoporosis

TITLE OF STUDY: .The Relationship. Between.

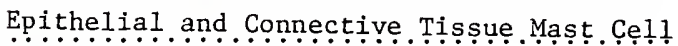

Populations in the Female Rat

FOR COMMITTEE USE ONLY Date Received........ Amount Requested:

Action:

Not Granted

Granted:

Full (\$)

Partial (\$)

Conditional ( $\$)$

Date of mailing award:

Date of receipt of

final report:

COMMENTS AND RECOMMENDATIONS

COMMITTEE ACTION

DATE OF MEETING

$\ldots \ldots \ldots \ldots$

ADDITIONAL REMARKS 
Please type or print all information

APPLIGATION FOR GRANT-IN-AID OF RESEARCH

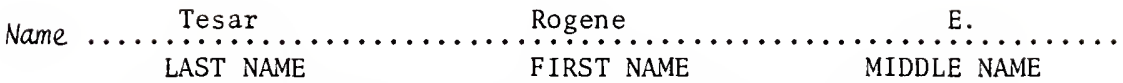

Address 6916 N.W. 20th P1ace, Gainesville, Florida 32605

42

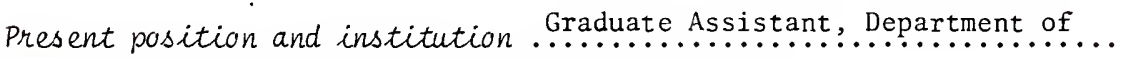
Obstetrics and Gynecology, University of Florida

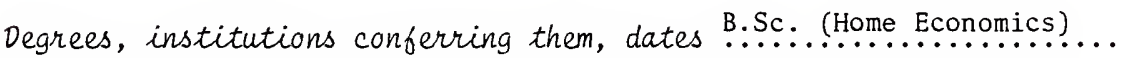
Kansas State University, 1962; B.Sc. (Food Science) University of Florida, 1977 ; M.Ag. (Human Nutrition) University of Florida, 1979; Ph.D. (in progress) University of Florida

Membership in SIGMA XI non-member

Please attach a list of titles of articles published during the last five years, with names of periodicals and dates: List of titles appended ...........

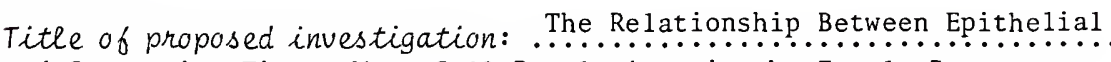
and Connective Tissue Mast Cell Populations in the Female Rat

Proposed investigation, described in non-technical language:

Previous studies suggest a relationship between bone marrow mast cell (MC) activity and local bone loss. There is also evidence that changes in skin MC activity may be indicative of bone loss. The proposed study is designed: 1) to determine whether a correlation exists in female rats between $M C$ activity in bone marrow and vaginal tissue and 2) to examine the effects of calcium- and vitamin D-deficient diets, exogenous estrogens and removal of the ovaries on this relationship.

The following hypotheses will be tested: 1) dietary calcium and vitamin D deficiences produce an increase in bone marrow MCs and a decrease in vaginal epithelial MCs in female rats; 2) administration of exogenous estrogens alters the bone and vaginal tissue MC activity in the osteoporotic female rat; and 3 ) removal of the ovaries (removal of primary source of endogenous estrogens) produces changes in bone and vaginal tissue $M C$ activity in the female rat.

Should the correlation be shown to exist, a similar correlation in the pre-osteoporotic and osteoporotic human female could be suggested. 
At present there is no universally applicable, non-invasive method for evaluation of bone resorption and formation. Evaluation of MC activity in vaginal tissue may prove useful as a non-invasive means of detecting increased bone resorption (indicative of osteoporosis associated with endogenous or exogenous excess of corticosteroids, hyperthyroidism, hyperparathyroidism and osteomalacia). In a similar manner, the method could be used to assess treatment efficacy. 
Locations where problem will be studied: Department of Animal

Resources, J. Hillis Miller Health Center, University of Florida;

Department of Anima1 Science, College of Agriculture, University of

F1orida.

Nature of assistance desired and amount of grant needed, itemized:

Purchase of 128 Sprague-Dawley female rats $\$ 544.00$

Feed and bedding for above rats for 5 wk. period 394.25 TOTAL $\$ 938.25$

Institutional support for study of problem: Remaining necessary support to carry out entire research project: anesthesia estrogen, stains and chemicals, microscope slides and use of all equipment.

Previous grants received from SIGMA $X I$ and others: none

Other applications pending: none

Attach a list giving name of each assistant or co-worker, if any, engaged in the investigation:

List attached $x$ Number of co-workers 7

Names and addresses of at least two specialists* in this field who will be ASKED BY THE APPLICANT to send to Sigma Xi National Headquarters statements indicating (1) the importance of the proposed investigation and (2) the qualifications of the investigator. Morris Notelovitz, M.D., Ph.D., Dept. of Obstetrics and Gynecology, Box J-294 JHMHC, College of Medicine, U of F, Gainesvi1le, FL 32610 J.P. Feaster, Ph.D. Dept. of Animal Science, 20 Nutrition Lab IFAS College of Agriculture, U of F, Gainesville, FL 32610

*If applicant is a degree candidate, one must be that faculty or research staff member supervising his research.

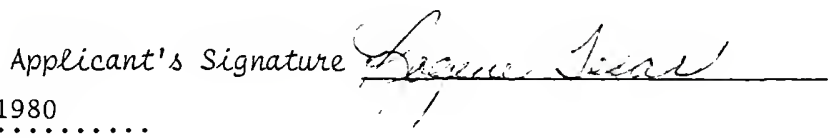

Date October 28, $1980 \ldots \ldots$ 
Title: The Relationship Between Epithelial and Connective Tissue Mast Cell Populations in the Female Rat

Investigator: Rogene Tesar

Assistants and Co-workers Engaged in Investigation:

Morris Notelovitz, M.D., Ph.D. Advisor - Endocrine Functions

J.P. Feaster, Ph.D.

Advisor - Dietary

A.F. Moreland, D.V.M.

Laboratory Assistance

Laboratory Technician of Dr. Moreland

Laboratory Assistance

Marsha Ware

Laboratory Assistance

Lynda McKenzie, R.N.

Laboratory Assistance

Cindy Soroski

Statistical Assistance 


\section{The University of Florida College of Medicine}

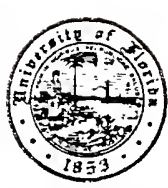

Department of Obstetrics and Gynecology

November 26,1980

BOX J-294, JHMHC

GAINESVILLE, FLORIDA 32610

TELEPHONE : 904.392 .2893

Committee on Awards

Sigma Xi

National Headquarters

345 Whitney Avenue

New Haven, CT 06511

RE: Application by Rogene Tesar for grant to investigate the relationship between epithelial and connective tissue mast cell population in the female rat.

Sirs,

The above apolication relates to the potential role that mast cell activity may have in the development of osteoporosis, a condition that affects some 258 of menopausal women and about 75 of of women who have undergone a surgical menopause. Osteoporosis is a significant disease since it is not only associated with pathologic fractures and potential invalidism, but can frequently result in the premature death of elderly women. One of the problems in the clinical management of this condition is the difficulty of its diagnosis and measurement of its response to treatment. Mrs. Tesar's research could provide the answer to this problem.

I have been acquainted with Mrs. Tesar for approximately two years and am currently an advisor to her for her Ph.D. requirements. She is a highly competent research worker, and $I$ am confident that she will be able to accomplish all the goals of her research project. I have no hesitation in supporting her request.

Warm kind regards.

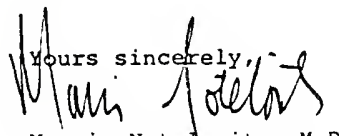

Morris Note lovitz, M.D. (RAND), Ph.D., F.R.C.O.G. F.A.C.O.G.

Director of the Center for Climacteric Studies

$\mathrm{MN}: \mathrm{mlh}$ 


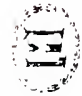

Sigma XI, The SCIENTIFIC RESEARCh SOCIETY

OFFICE OF THE COMMITTEE ON AWARDS

20 April 1981

345 WHITNEY AVENUE NEW HAVEN, CONNECTICUT 065I (203) 624-9833

Ms. Rogene E. Tesar

6916 N.W. 20th Place

Gainesville, FL 32605

Dear Ms. Tesar:

I am happy to inform you that at a recent meeting of the Committee on Awards a Grant-in-A1d of Research of $\$ 250.00$ was given you to further the work in your application: The Relationship Between Epithelial and Connective Tissue Mast Cell Populations in the Female Rat. Please complete the enclosed acceptance form so that we may write and forward your check.

This award is one of elght made posstble this year from the income of a specific gift to the Research Fund by Mrs. Daisy Yen Wu in memory of her husband, Dr. Hsien Wu.

It is understood that in accepting this award you will at the close of the academlc year (1981-82) submit a report of the work done to the Committee on Awards, Sigma XI, The Sclentific Research Society, 345 Whitney Avenue, New Haven, Conn. 06511. This should be a short one or two-page sumnary of the work accomplished with your Sigma XI grant.

It is further understood that all published reports of your work will contain a statement that the research was aided by a Grant-in-Aid of Research from Sigma $\mathrm{Xi}$, The Scientific Research Soclety. Also, any equipment purchased with the funds which have been made available is to be considered the property of the institution where the research is being carried on. It is also to be understood that no Indirect costs are to be paid to your institution from this grant.

It is a great pleasure to express the Comnittee's hope for your continued success in scientific research.

Sincerely yours,

\section{B. Var Houter m}

Franklyn B. Van Houten Chairman

FVH/ia

Enclosure 
Date April 27, 1981

Committee on Awards

Sigma Xi, The Scientific Research Society

345 Whitney Avenue

New Haven, CT 06511

Gentlemen:

I have received your letter stating that a grant has been awarded to me by the Committee on Awards.

I. (X) I accept the award in the amount of $\$ 250$.

( ) I cannot accept the award because

( ) I shall let you know by or not I can accept it.

whether

II. The name of the President or Chancellor or Chief Executive officer of my institution is:

President: Robert Q. Marston

III. The name of the Head or Chairman of my Department is:

Animal Science: H.D. Wallace, Chairman Center for Climacteric Studies:

M. Notelovitz, M.D., Ph.D.

IV. Will you please have Sigma Xi, the scientific Research Society, forward to me a check made payable for the amount of the award. I understand that it will be sent to my institutional address only, and I have made arrangements for its being forwarded if necessary.

NAME (Please Print): Rogene Tesar, R.D., M.Ag.

INSTITUTIONAI ADDRESS ONLY :

Center for CIimacteric studies Univ. of Fla., 901 N.W. $20 \mathrm{Pl}$. Suite B-1 Gainesville, FL 32601

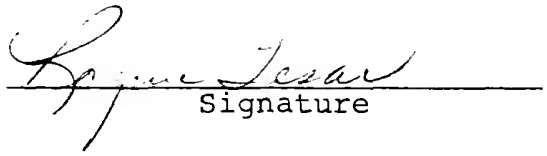




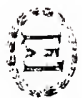

Sigma Xi, The Scientific Research Society OFFICE OF THE
EXECT:TIVE DIRECTOR
345 WHITNEY AVF,NLF NEW HAVEN CONNECTICUTMGI (20:3) 624. Yont3

Ms. Rogene E. Tesar

University of Florida

Center for Cifmacteric Studies

901 N.W. 20 th Place

Suite $B-1$

Gainesville, FL 32601

Dear Ms. Tesar:

Enclosed please find our check in the amount of $\$ 250.00$, which represents the Grant-in-Aid of Research award made to you by the Sigma X1 Comittee on Grants-in-Aid at their March meeting.

This award is one of eight made possibie this year from the income of a specific gift to the Research Fund by Mrs. Dalsy Yen Wu in memory of her husband, Dr. Hsien Wu.

Upon completion of your research a report of your findings should be forwarded to the Committee on Grants-in-Aid, 345 Whitney Avenue, New Haven, CT 06511.

May I take this opportunity to wish you every success with your research.

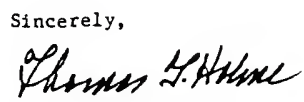

Thomas T. Holme

Executive Director

TTH/ia

Enclosure

cc: Office of the President Department Chairman 


\section{APPENDIX B}

LABORATORY ANIMAL USE 


\section{All University Comitieg on the Care and Use of Laboratory inimais}

in orjer to comoly with OHEN policy and all federal, state and local rales and regulations concernins the care, traatment and use of laboratory animals, the following iniormation is necessary for grants to be processed by the Division of Soonsored Research. Instructional programs and research projects supported intarnaliy using laboratory animals must also complete this questionnaire and return to the Comittee completing the appropriate parts.

1. Principal investigator: Rogene E. Tesar

Departinent obstetrfcs and Gynecology

College College of Medicine

Telephone 392-3184 Date Nov. 17, 1980

2. Proposal submitted to:

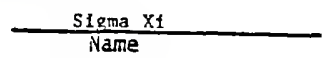

$\frac{345 \text { Whitney Ave., New Haven, }}{\text { A0eress Conn. } 06511}$

3. Starting date: December 15, 1980 ; conclusion: August 30,1981

4. Proposal title:

The Relationships Between Eptthelial and Connective Tissue Mast Cell
Populations In the Female Rat

5. Animal species: Rat

Strains Sprague-Dawley

Numbers 137

Sex Female

Age 3 weeks and 2 months

Siza $50 \mathrm{gram}$ and $120 \mathrm{gram}$

f. Is the enimal-model eppropriate?

Explain Yes. The female rat has been used in many experiments involving

the mast cell. The metabolism of the rat closely relates to that of the human and will produce results due to the treatment given which can be Implicated as occurring in the human.

7. Abstrace of enimal use:

(Usa continuation sheet if needed)

137 rats w111 be utilized to observe differences in population and activity of the mast cell in bone and vaginal tissue. Of these rats, 12 will be utilized for a preliminary trial to define whether mature rats or weanings are to be bsed fpr
treatment (a) castration. Treatments are as follows: a) castration 70 rats) at beginning of study b) estrogen (LV.) (67 rats) $3 x$ week for 5 weeks c) norma

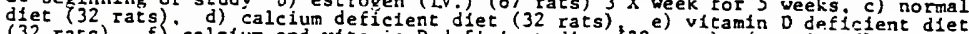
8. Care and location of animals:

The rats will be maintained at the Anfmal Resources Department, JHMC, Unfversity of Florida in individual cages with daily care and feeding.

9. Is the study designed to avoid inflicting needless pain and/or suffering including the appropriats use of tranquilizers, anaigesics and/or anesthetics? If not, explain: Yes: Anesthesia will be used for surgery purposes.

10. Method(s) of euthanasia to be usad:

At the end of a maximum 5 week feeding period, the rats will be killed by

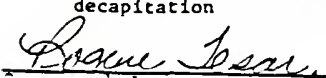

Frirctpal investigator

Rogene Tesar, M.A., R.D.

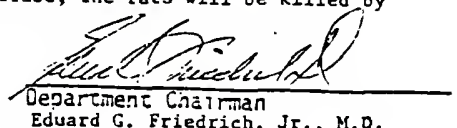

Eduard G. Friedrich, Jr., M.D. 
All University Committee on the Care and Use of Laboratory Animals

Continuation Sheet

7. h) photon absorptiometry of the femur and tibia during the 5 week diet period. Castration (removal of ovaries) will be performed under anesthetization. At the termination of the 5 week diet period the rats will be killed by decapitation, Bone and vaginal tissue specimens will be obtained for histological purposes. 
University of Florida

All-University Committee for

The Care and Use of

Laboratory Animals

1. Acknowledge receipt of your form for the care and use of laboratory animals entitled:

"The Relationship Between Epithelial and Connective Tissue Mast Cell Populations in the Female Rat" submitted $11 / 17 / 80$.

2. Review Results

Approval: $\mathrm{XX}$

Disapprova1:

Incomplete-please provide

3. For questions, please call: Dr. Halliwell at (904) 392-4751. 
APPENDIX C

EXPERIMENTAL ANIMAL BODY WEIGHTS

TABLE C. 1

NORMAL DIET

\begin{tabular}{|c|c|c|c|c|c|c|}
\hline $\begin{array}{c}\text { Sample } \\
\text { ID }\end{array}$ & OW & $1 \mathrm{~W}$ & $2 \mathrm{~W}$ & $3 W$ & $4 W$ & $5 \mathrm{~W}$ \\
\hline 1 & 192 & 197 & 195 & 191 & 195 & 196 \\
\hline 2 & 175 & 184 & 189 & 197 & 200 & 204 \\
\hline 3 & 184 & 198 & 202 & 208 & 213 & 212 \\
\hline 4 & 180 & 186 & 187 & 190 & 192 & 193 \\
\hline 5 & 185 & 198 & 198 & 201 & 204 & 209 \\
\hline 6 & 183 & 183 & 189 & 196 & 199 & 200 \\
\hline 7 & 186 & 187 & 195 & 197 & 197 & 198 \\
\hline 8 & 197 & 204 & 237 & 231 & 234 & 237 \\
\hline 9 & 195 & 195 & 227 & 259 & 276 & 280 \\
\hline 10 & 189 & 196 & 251 & 299 & 321 & 332 \\
\hline 11 & 185 & 196 & 240 & 264 & 282 & 294 \\
\hline $\begin{array}{l}12 \\
13\end{array}$ & 212 & 205 & 248 & 291 & 308 & 315 \\
\hline 14 & 195 & 198 & 253 & 282 & 297 & 309 \\
\hline 15 & 177 & 175 & 222 & 257 & 270 & 278 \\
\hline 16 & 184 & 195 & 259 & 298 & 325 & 337 \\
\hline 17 & 177 & 182 & 206 & 217 & 219 & 217 \\
\hline 18 & 183 & 187 & 197 & 205 & 209 & 206 \\
\hline 19 & 183 & 202 & 199 & 228 & 231 & 230 \\
\hline 20 & 197 & 191 & 215 & 209 & 214 & 216 \\
\hline 21 & 191 & 196 & 206 & 214 & 204 & 206 \\
\hline 22 & & & & & & \\
\hline 23 & 184 & 190 & 190 & 208 & 204 & 209 \\
\hline 24 & 201 & 209 & 254 & 242 & 241 & 245 \\
\hline 25 & 194 & 203 & 225 & 234 & 244 & 250 \\
\hline 26 & 206 & 204 & 230 & 238 & 255 & 264 \\
\hline 27 & 196 & 209 & 228 & 247 & 251 & 255 \\
\hline 28 & 200 & 209 & 242 & 267 & 275 & 285 \\
\hline 29 & 171 & 188 & 201 & 217 & 226 & 228 \\
\hline 30 & 180 & 191 & 231 & 250 & 256 & 263 \\
\hline 31 & 209 & 214 & 241 & 267 & 273 & 275 \\
\hline 32 & 194 & 199 & 226 & 245 & 252 & 259 \\
\hline
\end{tabular}

Weights expressed in grams 
TABLE C. 2

-Ca DIET

\begin{tabular}{|c|c|c|c|c|c|c|c|c|c|c|c|}
\hline $\begin{array}{c}\text { Sample } \\
\text { ID }\end{array}$ & OW & & $1 \mathrm{~W}$ & & & & & & & $5 W$ & $6 W$ \\
\hline 1 & 161 & 179 & 176 & 179 & 177 & 169 & 171 & 176 & 176 & 175 & 181 \\
\hline 2 & 187 & 204 & 197 & 197 & 196 & 195 & 196 & 202 & 196 & 195 & 205 \\
\hline 3 & 181 & 192 & 189 & 190 & 197 & 193 & 198 & 196 & 198 & 197 & 195 \\
\hline 4 & 183 & 202 & 201 & 197 & 196 & 196 & 193 & 199 & 199 & 208 & 209 \\
\hline 5 & 175 & 175 & 176 & 187 & 190 & 188 & 196 & 200 & 201 & 202 & 200 \\
\hline 6 & 175 & 187 & 185 & 185 & 184 & 181 & 188 & 188 & 195 & 195 & 197 \\
\hline 7 & 177 & 194 & 192 & 182 & 173 & 185 & 187 & 189 & 188 & 186 & 190 \\
\hline 8 & 183 & 198 & 205 & 210 & 210 & 210 & 215 & 213 & 214 & 212 & 215 \\
\hline $1 a$ & 211 & 211 & & 211 & & 215 & & 216 & & 222 & \\
\hline $2 a$ & 197 & 201 & & 213 & & 212 & & 213 & & 211 & \\
\hline $3 a$ & 182 & 187 & & 187 & & 194 & & 200 & & 194 & \\
\hline $4 a$ & 188 & 196 & & 203 & & 203 & & 209 & & 211 & \\
\hline 9 & 181 & 191 & 210 & 225 & 239 & 247 & 255 & 261 & 275 & 274 & 290 \\
\hline 10 & 167 & 174 & 190 & 205 & 220 & 226 & 236 & 244 & 250 & 259 & 265 \\
\hline 11 & 190 & 204 & 222 & 248 & 262 & 275 & 286 & 295 & 301 & 305 & 310 \\
\hline 12 & 204 & 210 & 233 & 264 & 282 & 295 & 310 & 320 & 328 & 336 & 342 \\
\hline 13 & 170 & 178 & 203 & 221 & 238 & 242 & 253 & 259 & 268 & 275 & 285 \\
\hline 14 & 168 & 184 & 200 & 228 & 247 & 257 & 270 & 276 & 279 & 290 & 294 \\
\hline 15 & 194 & 212 & 226 & 241 & 255 & 260 & 262 & 263 & 258 & 265 & 265 \\
\hline 16 & 185 & 199 & 217 & 242 & 258 & 274 & 291 & 299 & 303 & 310 & 317 \\
\hline $5 a$ & 191 & 192 & & 251 & & 275 & & 292 & & 298 & \\
\hline $6 a$ & 177 & 177 & & 214 & & 253 & & 269 & & 278 & \\
\hline $7 a$ & 186 & 196 & & 243 & & 283 & & 295 & & 306 & \\
\hline $8 a$ & 183 & 191 & & 239 & & 275 & & 291 & & 299 & \\
\hline 17 & 184 & 207 & 192 & 195 & 194 & 200 & 203 & 213 & 208 & 215 & 218 \\
\hline 18 & 196 & 195 & 201 & 205 & 205 & 209 & 215 & 224 & 223 & 233 & 228 \\
\hline 19 & 187 & 201 & 204 & 215 & 219 & 229 & 233 & 233 & 234 & 242 & 235 \\
\hline 20 & 202 & 217 & 213 & 220 & 229 & 236 & 233 & 239 & 239 & 234 & 244 \\
\hline 21 & 172 & & & & & & & & & & \\
\hline 22 & 167 & 186 & 184 & 192 & 190 & 191 & 191 & 201 & 203 & 207 & 207 \\
\hline 23 & 183 & 198 & 197 & 206 & 207 & 215 & 230 & 215 & 215 & 214 & 204 \\
\hline 24 & 200 & 216 & 217 & 225 & 219 & 230 & 216 & 235 & 232 & 234 & 220 \\
\hline 25 & 181 & 189 & 189 & 199 & 199 & 202 & 205 & 210 & 209 & 210 & 210 \\
\hline 26 & 184 & 198 & 210 & 220 & 225 & 228 & 239 & 246 & 246 & 245 & 249 \\
\hline 27 & 187 & 195 & 203 & 214 & 219 & 224 & 230 & 233 & 236 & 242 & 241 \\
\hline 28 & 181 & 188 & 194 & 201 & 206 & 210 & 212 & 216 & 219 & 222 & 223 \\
\hline 29 & 173 & 190 & 203 & 208 & 216 & 217 & 223 & 228 & 228 & 235 & 235 \\
\hline 30 & 177 & 198 & 211 & 223 & 225 & 228 & 234 & 239 & 242 & 245 & 247 \\
\hline 31 & 185 & 204 & 210 & 219 & 226 & 231 & 242 & 247 & 239 & 242 & 245 \\
\hline 32 & 191 & 204 & 213 & 221 & 228 & 232 & 241 & 248 & 242 & 245 & 249 \\
\hline
\end{tabular}

Weights expressed in grams 


\section{TABLE C. 3 \\ -D DIET}

\begin{tabular}{|c|c|c|c|c|c|c|}
\hline $\begin{array}{c}\text { Sample } \\
\text { ID }\end{array}$ & & & $1 \mathrm{~W}$ & $2 W$ & $3 W$ & $4 \mathrm{~W}$ \\
\hline 1 & 144 & 161 & 165 & 164 & 172 & 168 \\
\hline 2 & 157 & 166 & 167 & 167 & 170 & 176 \\
\hline 3 & 146 & 173 & 171 & 167 & 174 & 174 \\
\hline 4 & 158 & 181 & 179 & 186 & 196 & 198 \\
\hline 5 & 146 & 165 & 166 & 165 & 176 & 180 \\
\hline 6 & 151 & 173 & 177 & 171 & 175 & 174 \\
\hline 7 & 154 & 171 & 169 & 168 & 173 & 177 \\
\hline 8 & 154 & 180 & 175 & 172 & 171 & 172 \\
\hline 9 & 156 & 180 & 187 & 207 & 223 & 232 \\
\hline 10 & 175 & 190 & 193 & 208 & 224 & 234 \\
\hline 11 & 161 & 173 & 174 & 189 & 204 & 214 \\
\hline 12 & 153 & 165 & 172 & 182 & 200 & 216 \\
\hline 13 & 203 & 192 & 196 & 213 & 231 & 250 \\
\hline 14 & 184 & 183 & 184 & 203 & 210 & 219 \\
\hline 15 & 173 & 166 & 164 & 179 & 201 & 213 \\
\hline 16 & 177 & 176 & 179 & 203 & 220 & 230 \\
\hline 17 & 202 & 209 & 199 & 196 & 210 & 218 \\
\hline 18 & 134 & 145 & 146 & 149 & 161 & 163 \\
\hline 19 & 136 & 151 & 157 & 158 & 170 & 176 \\
\hline 20 & 142 & 165 & 169 & 169 & 173 & 177 \\
\hline 21 & 148 & 174 & 177 & 181 & 195 & 193 \\
\hline 22 & 161 & 189 & 190 & 189 & 203 & 206 \\
\hline 23 & 139 & 157 & 158 & 163 & 169 & 172 \\
\hline 24 & 152 & 177 & 181 & 183 & 190 & 194 \\
\hline 25 & 133 & 149 & 158 & 168 & 173 & 188 \\
\hline 26 & 154 & 176 & 182 & 188 & 201 & 210 \\
\hline 27 & 149 & 172 & 171 & 185 & 197 & 208 \\
\hline 28 & 155 & 181 & 184 & 203 & 210 & 217 \\
\hline 29 & 150 & 169 & 174 & 182 & 191 & 199 \\
\hline 30 & 175 & 171 & 174 & 182 & 193 & 197 \\
\hline 31 & 187 & 180 & 179 & 195 & 211 & 219 \\
\hline 32 & 184 & 183 & 185 & 191 & 191 & 203 \\
\hline
\end{tabular}

Weights expressed in grams 
TABLE C. 4

-Ca, -D DIET

\begin{tabular}{|c|c|c|c|c|c|c|}
\hline $\begin{array}{l}\text { Sample } \\
\text { ID }\end{array}$ & OW & $1 \mathrm{~W}$ & $2 W$ & $3 W$ & $4 W$ & $5 \mathrm{~W}$ \\
\hline 1 & 204 & 217 & 211 & 223 & 229 & 228 \\
\hline 2 & 204 & 215 & 210 & 224 & 225 & 217 \\
\hline 3 & 199 & 207 & 199 & 213 & 224 & 231 \\
\hline 4 & 176 & 184 & 180 & 187 & 194 & 196 \\
\hline 5 & 194 & 202 & 190 & 197 & 207 & 206 \\
\hline 6 & 187 & 192 & 190 & 201 & 203 & 202 \\
\hline 7 & 218 & 225 & 216 & 230 & 239 & 242 \\
\hline 8 & 184 & 185 & 186 & 194 & 196 & 197 \\
\hline 9 & 205 & 205 & 234 & 269 & 294 & 315 \\
\hline 10 & 171 & 183 & 214 & 251 & 272 & 287 \\
\hline 11 & 212 & 194 & 258 & 303 & 329 & 343 \\
\hline 12 & 191 & 200 & 238 & 278 & 305 & 318 \\
\hline 13 & 187 & 198 & 223 & 262 & 280 & 300 \\
\hline 14 & 197 & 214 & 239 & 283 & 306 & 323 \\
\hline 15 & 212 & 223 & 224 & 240 & 248 & 258 \\
\hline 16 & 197 & 208 & 204 & 224 & 228 & 242 \\
\hline 17 & 196 & 205 & 209 & 246 & 222 & 177 \\
\hline 18 & 196 & 209 & 224 & 214 & 252 & 253 \\
\hline 19 & 221 & 229 & 234 & 244 & 258 & 246 \\
\hline 20 & 195 & 197 & 209 & 224 & 234 & 215 \\
\hline 21 & 198 & 210 & 209 & 212 & 200 & 190 \\
\hline 22 & 201 & 212 & 216 & 230 & 232 & 231 \\
\hline 23 & 210 & 212 & 215 & 234 & 245 & 234 \\
\hline 24 & 200 & 201 & 202 & 220 & 229 & 198 \\
\hline 25 & 211 & 224 & 248 & 246 & 268 & 268 \\
\hline 26 & & & & & & \\
\hline 27 & 217 & 225 & 237 & 243 & 259 & 266 \\
\hline 28 & 205 & 213 & 220 & 231 & 259 & 257 \\
\hline 29 & 214 & 229 & 243 & 257 & 270 & 277 \\
\hline 30 & 194 & 201 & 219 & 225 & 253 & 247 \\
\hline 31 & 194 & 203 & 221 & 229 & 241 & 247 \\
\hline 32 & 207 & 208 & 242 & 225 & 268 & 280 \\
\hline
\end{tabular}

Weights expressed in grams 


\section{APPENDIX D \\ COMPOSITION OF EXPERIMENTAL DIETS}

AIN-76 Semipurified Diet (Ca:P 1.14:1)*

Casein

DL-Methionine

Cornstarch

Sucrose

Fiber

Corn Oil

AIN Mineral mix

Calcium Phosphate, Dibasic $\left(\mathrm{CaHPO}{ }_{4}\right)$

Sodium Chloride ( $\mathrm{NaCl}$ )

Potassium Citrate, Monohydrate

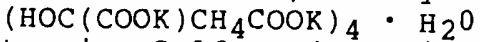

Potassium Sulfate $\left(\mathrm{K}_{2} \mathrm{SO}_{4}\right)$

Magnesium Oxide (MgO)

Manganous Carbonate (43-48\% $\mathrm{Mn}$ )

Ferric Citrate $(16-178$ Fe)

Zinc Carbonate ( 70 \% $\mathrm{ZnO}$ )

Cupric Carbonate $(53-558 \mathrm{Cu})$

Potassium Iodate $\left(\mathrm{KIO}_{3}\right)$

Sodium Selenite $\left(\mathrm{Na}_{2} \mathrm{SeO}_{3} \cdot 5 \mathrm{H}_{2} \mathrm{O}\right)$

Chromium Postassium sulfate (CrK $\left(\mathrm{SO}_{4}\right)_{2} \cdot 12 \mathrm{H}_{2} \mathrm{O}$ )

Sucrose, finely powdered

All Vitamin mix

Thiamine $\mathrm{HCl}$

Riboflavin

Pyridoxine $\mathrm{HCl}$

Nicotinic Acid

D-Calcium Pantothenate

Folic Acid

(Vit. E), Pre-mix

Cholecalciferol (Vit. $\mathrm{D}_{3}$ )

Menaquinone (Vit. K)

Sucrose, finely powdered

Choline bitrate

0.28

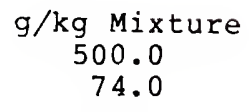

220.0

52.0

24.0

3.5

6.0

1.6

0.3

0.01

0.01

0.55

118.0

per $\mathrm{kg}$ Mixture

$600 \mathrm{mg}$

$600 \mathrm{mg}$

$700 \mathrm{mg}$

$3 \mathrm{mg}$

$1.6 \mathrm{mg}$

200 myl Acetate

$20 \mathrm{~g}$

$2.5 \mathrm{mg}$

$5.0 \mathrm{mg}$

$972.9 \mathrm{~g}$

*Obtained from Nutritional Biochemicals, Cleveland, OH 
Calcium Deficient Diet (Ca:P .07:1)*

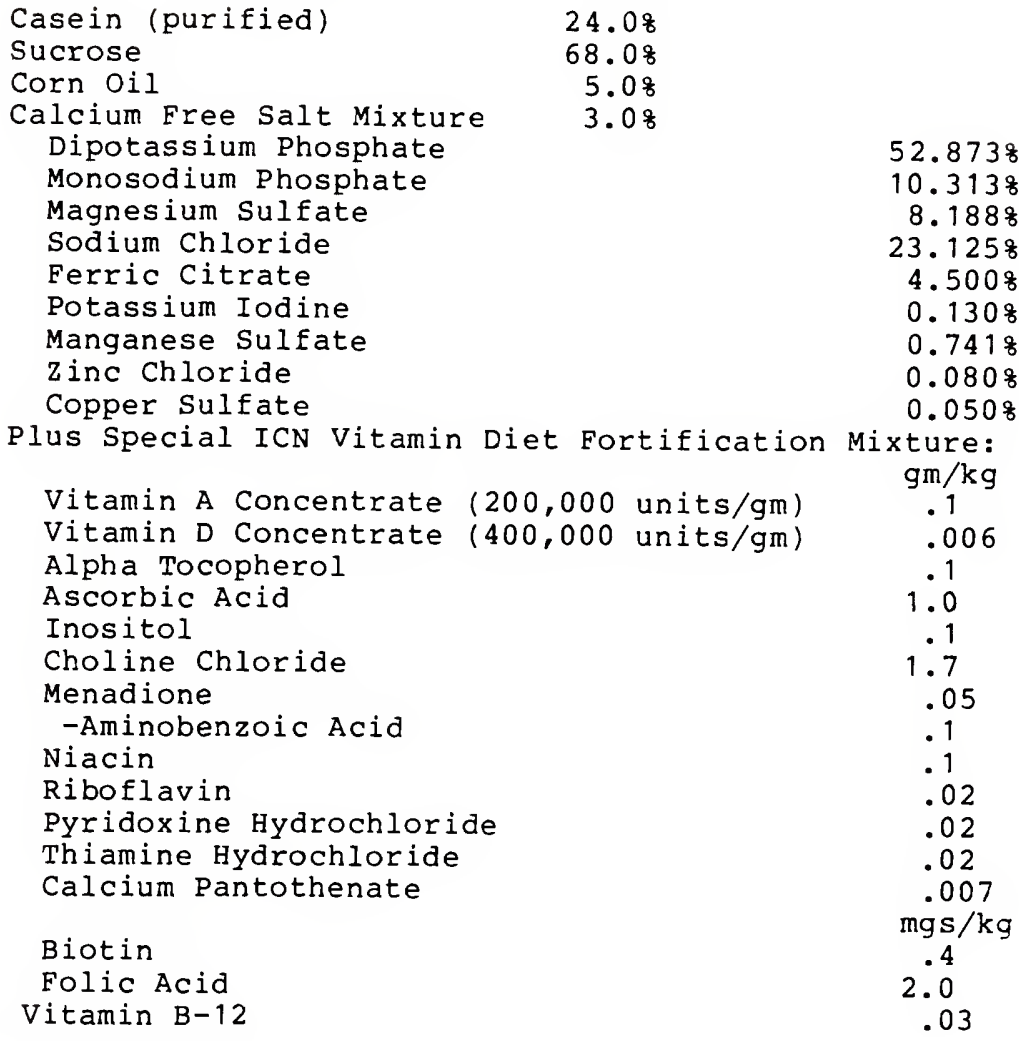

$\frac{\text { Rachitogenic U.S.P. No. } 2 \text { Diet }}{\text { (Ca:P } 4.23: 1)^{\star}}$

Ground Gluten

208

Ground Whole Yellow Maize $76 \%$

Calcium Carbonate $3 \frac{8}{8}$

Sodium Chloride 18

Custom Vitamin D and Calcium Deficient Diet

(Ca:P .07:1)*

Based on the Calcium-Deficient Diet with omission of Vitamin D Concentrate

* Obtained from Nutritional Biochemicals, Cleveland, OH

** Formulated and obtained from Nutritional Biochemicals, Cleveland, OH 


\section{APPENDIX E \\ SERUM CALCIUM ANALYSIS}

Sample Collection and Procedure ${ }^{1}$

Blood was obtained at decapitation of the laboratory rats by exsanguanation. The blood was collected in tubes, allowed to clot and centrifuged. Serum was drawn off using Pasteur glass pipettes, transferred to clean tubes, labeled, and frozen for future determination.

A protein-free filtrate was required for analysis of calcium. After thawing the serum samples at room temperature for one half-hour, precipitation of serum protein was accomplished as follows:

(a) $9 \mathrm{ml} 10 \%$ (w/v) trichloracetic acid (TCA) were delivered into labeled test tubes.

(b) $1 \mathrm{ml}$ serum from each well-mixed sample was pipetted into the TCA.

(c) the solutions were mixed on a vortex mixer, allowed to stand for 10 minutes, and centrifuged 10 minutes at 2,500 rpm. This filtrate represented a $1 \rightarrow 10$ dilution of the serum samples.

(d) $1 \mathrm{ml}$ of the supernatant was diluted to $5 \mathrm{ml}$ with 1\% lanthanum. The dilution factor was $10 \times 5=50$.

$\overline{I_{\text {Fick et al. }}, 1979}$ 
This procedure provided the appropriate serum calcium concentration for the reading of absorbance by the PerkinElmer 306 atomic absorption spectrophotometer (AAS), which has a linear working range of $7 \mathrm{ppm}$ for calcium. Confirmation of the above is shown by the following calculation:

calcium concentration $=\frac{\begin{array}{l}\text { (ppm calcium expected } \\ \text { for original sample) }\end{array} \text { (ml sample) }}{\text { sample dilution }}$ calcium concentration $=\frac{(100 \mathrm{ppm}) \times(1 \mathrm{ml})}{50 \mathrm{ml}}$. calcium concentration $=2$ ppm .

Calcium standards of $0,2,3,4,5$, and $7 \mu \mathrm{g} / \mathrm{ml}$ were prepared in $100 \mathrm{ml}$ volumetric flasks. The 1,000 ppm stock standard calcium solution was first diluted to $100 \mathrm{ppm}$. Each standard was made to contain $18 \mathrm{ml}$ of $10 \% \mathrm{TCA}$ to match the final dilution of serum and $16 \mathrm{ml}$ of 5\% lanthanum. Table E.I lists the concentration and absorbance of the standards, as read by AAS.

TABLE E.1

SERUM CALCIUM STANDARDS

$\underline{\text { Standard }}$

$\underline{\mu \mathrm{g} / \mathrm{ml}}$

0

2

3

4

5
7

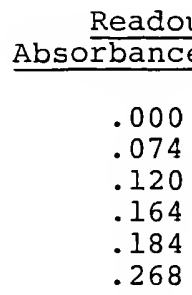

$\frac{\text { Calculated }}{\text { Slope (a) }}$

.000

.037

.040

.041

.037

.038

Calcium in the sample solutions was then measured for absorbance by AAS and concentration was calculated as mg/100 ml serum as follows: 
sample ppm $=\frac{(\text { absorbance }) \times \text { (dilution factors) }}{\text { (slope) }} \times \frac{\text { (sample weight) }}{x}$

This equation is derived from Beer's Law, which states that $A=a b c$

where
$\mathrm{A}=$ absorbance (optical density)
$\mathrm{a}=$ absorptivity or slope of the standard
$\mathrm{b}=$ length of the light path (always constant)
$c=$ concentration

The absorbance reading was obtained from the machine. The slope was determined as an average of the slopes of the standards ( $a=A / C$ from Beer's Law). The slope used in calculations for samples was .0386 , obtained from Table E.l.

Tables E.2 through E.5 contain serum calcium concentration values of the laboratory rats. 
TABLE E. 2

SERUM CALCIUM ANALYSIS DATA

Rat Diet Normal

Total Dilution
Date

Technician R. Tesar

\begin{tabular}{|c|c|c|c|}
\hline \multirow{2}{*}{$\begin{array}{c}\text { Sample } \\
\text { ID }\end{array}$} & Readout & \multirow[b]{2}{*}{$\mathrm{ppm}$} & \multirow[b]{2}{*}{$\mathrm{mg} / 100 \mathrm{ml}$} \\
\hline & Absorbance & & \\
\hline 1 & .100 & 129.5 & 13.0 \\
\hline 2 & .099 & 128.2 & 12.8 \\
\hline 3 & .096 & 124.4 & 12.4 \\
\hline 4 & .097 & 125.6 & 12.6 \\
\hline 5 & .097 & 125.6 & 12.6 \\
\hline 6 & .102 & 132.1 & 13.2 \\
\hline 7 & .102 & 132.1 & 13.2 \\
\hline 8 & .082 & 106.2 & 10.6 \\
\hline 9 & .103 & 133.4 & 13.3 \\
\hline 10 & .067 & 86.8 & 8.7 \\
\hline 11 & .096 & 124.4 & 12.4 \\
\hline 12 & & & \\
\hline $\begin{array}{l}13 \\
14\end{array}$ & .084 & 108.8 & 10.9 \\
\hline 15 & .088 & 114.0 & 11.4 \\
\hline 16 & .092 & 119.2 & 11.9 \\
\hline 17 & .082 & 106.2 & 10.6 \\
\hline 18 & .088 & 114.0 & 11.4 \\
\hline 19 & .091 & 117.9 & 11.8 \\
\hline 20 & .092 & 119.2 & 11.9 \\
\hline $\begin{array}{l}21 \\
22\end{array}$ & .098 & 126.9 & 12.7 \\
\hline $\begin{array}{l}22 \\
23\end{array}$ & .088 & 114.0 & 11.4 \\
\hline 24 & .093 & 120.5 & 12.1 \\
\hline 25 & .062 & 80.3 & 8.0 \\
\hline 26 & .074 & 95.9 & 9.6 \\
\hline 27 & .092 & 119.2 & 11.9 \\
\hline 28 & .070 & 90.7 & 9.1 \\
\hline 29 & .068 & 88.1 & 8.8 \\
\hline 30 & .068 & 88.1 & 8.8 \\
\hline 31 & .073 & 94.6 & 9.5 \\
\hline 32 & .087 & 112.7 & 11.3 \\
\hline
\end{tabular}


TABLE E. 3

SERUM CALCIUM ANALYSIS DATA

Rat Diet

Total Dilution
Date

Technician
$2 / 16 / 82$

R. Tesar

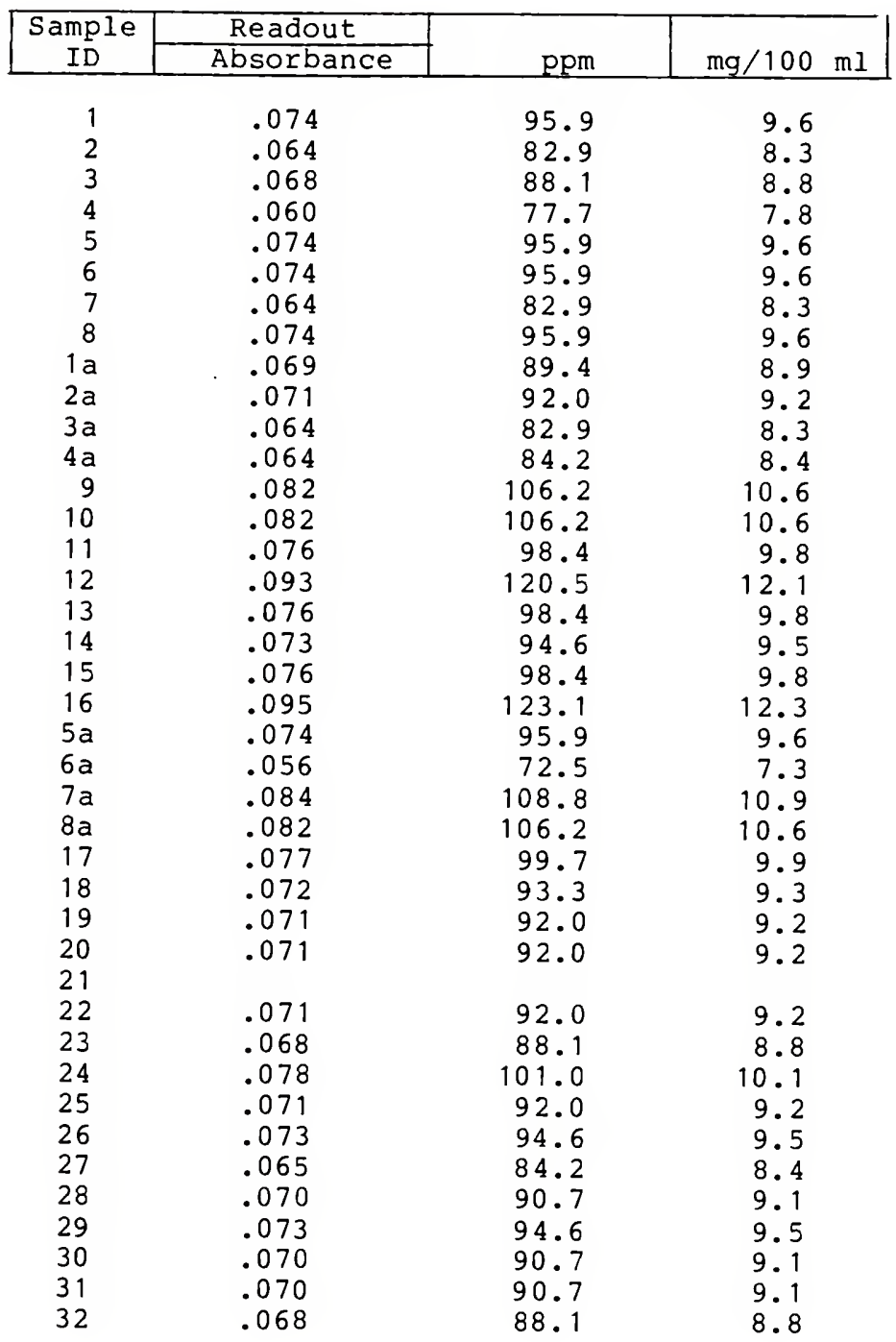


TABLE E. 4

SERUM CALCIUM ANALYSIS DATA

Rat Diet

Total Dilution 50
Date

Technician

\begin{tabular}{|c|c|c|c|}
\hline $\begin{array}{c}\text { Sample } \\
\text { ID }\end{array}$ & Readout & mחn & $\mathrm{ma} / 10 \mathrm{n} \mathrm{ml}$ \\
\hline $\begin{array}{r}1 \\
2 \\
3 \\
4 \\
5 \\
6 \\
7 \\
8 \\
9 \\
10 \\
11 \\
12 \\
13 \\
14 \\
15 \\
16 \\
17 \\
18 \\
19 \\
20 \\
21 \\
22 \\
23 \\
24 \\
25 \\
26 \\
27 \\
28 \\
29 \\
30 \\
31 \\
32\end{array}$ & $\begin{array}{l}.080 \\
.059 \\
.065 \\
.065 \\
.067 \\
.077 \\
.070 \\
.068 \\
.057 \\
.047 \\
.078 \\
.076 \\
.082 \\
.078 \\
.079 \\
.090 \\
.079 \\
.077 \\
.066 \\
.064 \\
.073 \\
.073 \\
.061 \\
.065 \\
.082 \\
.068 \\
.079 \\
.067 \\
.064 \\
.081 \\
.072 \\
.066\end{array}$ & $\begin{array}{r}103.6 \\
76.4 \\
84.2 \\
84.2 \\
86.8 \\
99.7 \\
90.7 \\
88.1 \\
73.8 \\
60.9 \\
101.0 \\
98.4 \\
106.2 \\
101.0 \\
102.3 \\
116.6 \\
102.3 \\
99.7 \\
85.5 \\
82.9 \\
94.6 \\
94.6 \\
79.0 \\
84.2 \\
106.2 \\
88.1 \\
102.3 \\
86.8 \\
82.9 \\
104.9 \\
93.3 \\
85.5\end{array}$ & $\begin{array}{r}10.4 \\
7.6 \\
8.4 \\
8.4 \\
8.7 \\
10.0 \\
9.1 \\
8.8 \\
7.4 \\
6.1 \\
10.1 \\
9.8 \\
10.6 \\
10.1 \\
10.2 \\
11.7 \\
10.2 \\
10.0 \\
8.6 \\
8.3 \\
9.5 \\
9.5 \\
7.9 \\
8.4 \\
10.6 \\
8.8 \\
10.2 \\
8.7 \\
8.3 \\
10.5 \\
9.3 \\
8.6\end{array}$ \\
\hline
\end{tabular}


TABLE E. 5

SERUM CALCIUM ANALYSIS DATA

Rat Diet

Rat Diet $\frac{-\mathrm{Ca}}{\text { Total Dilution }}$
Totion

50
Date

Technician
$2 / 16 / 82$

R. Tesar

\begin{tabular}{|c|c|c|c|}
\hline \multirow{2}{*}{$\begin{array}{c}\text { Sample } \\
\text { ID }\end{array}$} & Readout & \multirow[b]{2}{*}{$\mathrm{ppm}$} & \multirow[b]{2}{*}{$\mathrm{mg} / 100 \mathrm{ml}$} \\
\hline & Absorbance & & \\
\hline 1 & .059 & 76.4 & 7.6 \\
\hline 2 & .070 & 90.7 & 9.1 \\
\hline 3 & .071 & 92.0 & 9.2 \\
\hline 4 & .058 & 75.1 & 7.5 \\
\hline 5 & .057 & 73.8 & 7.4 \\
\hline 6 & .053 & 68.7 & 6.9 \\
\hline 7 & .072 & 93.3 & 9.3 \\
\hline 8 & .057 & 73.8 & 7.4 \\
\hline 9 & .053 & 68.7 & 6.9 \\
\hline 10 & .063 & 81.6 & 8.2 \\
\hline 11 & .079 & 102.3 & 10.2 \\
\hline 12 & .062 & 80.3 & 8.0 \\
\hline 13 & .057 & 73.8 & 7.4 \\
\hline 14 & .069 & 89.4 & 8.9 \\
\hline 15 & .065 & 84.2 & 8.4 \\
\hline 16 & .074 & 95.9 & 9.6 \\
\hline 17 & .031 & 40.2 & 4.0 \\
\hline 18 & .067 & 86.8 & 8.7 \\
\hline 19 & .043 & 55.7 & 5.6 \\
\hline 20 & .043 & 55.7 & 5.6 \\
\hline 21 & .031 & 40.2 & 4.0 \\
\hline 22 & .060 & 77.7 & 7.8 \\
\hline 23 & .036 & 46.6 & 4.7 \\
\hline 24 & .025 & 32.4 & 3.2 \\
\hline 25 & .055 & 71.2 & 7.1 \\
\hline 26 & & & \\
\hline 27 & .038 & 49.2 & 4.9 \\
\hline 28 & .023 & 29.8 & 3.0 \\
\hline 29 & .031 & 40.2 & 4.0 \\
\hline 30 & .017 & 22.0 & 2.2 \\
\hline 31 & .023 & 29.8 & 3.0 \\
\hline 32 & .048 & 62.2 & 6.2 \\
\hline
\end{tabular}




\section{APPENDIX F \\ DENSITOMETRIC BONE ANALYSIS}

\section{Instrumentation and Procedure}

A Norland Digital Bone Densitometer Model 278 (Norland Instruments, Ft. Atkinson, WI) was used to measure bone mineral content, bone width, and bone length in the excised, cleaned rat femur by direct photon absorptiometry. This technique measures the attenuation of a beam of gamma radiation by calcified tissue and is based on the concept that the mass of bone mineral present is directly proportional to the attenuation by bone (Sanchez et al., 1980).

The densitometer consisted of a scanner module and a computer module (Fig. F.I). The scanner transported a highly collimated beam of monoenergetic gamma rays from a radioactive sealed source of ${ }^{I 25} \mathrm{I}$ across the bone being measured. A 1/16" diameter detector collimator and a threshold setting of $85 \%$ were used to enhance accuracy. The computer module calculated the bone mineral content (BMC) and bone width (BW) values from the resulting absorption curve. These values and the bone profiles were displayed on the computer module screen. See Fig. F.2.

BMC and BW measurements were made at six distinct scan sites of the femoral bone, beginning at the edge of the 
lesser trochanter (proximal end) and progressing to the widening of the distal end. Scans were made perpendicular to the bone axis.

The quantity measurement of BMC is a linear mass density of $\mathrm{g} / \mathrm{cm}$ length of bone, an average linear density over the approximately $4 \mathrm{~mm}$ wide scan path. In terms of another explanation, BMC is the grams of mineral which would be obtained if a $1 \mathrm{~cm}$ thick crosswise slice were cut out of the bone and this slice were heated in a crucible to burn away all non-mineral material (Norland Corp., 1980).

$\mathrm{BW}$ represents the distance in $\mathrm{cm}$ from one longitudinal edge of the bone to the other.

The value of $\mathrm{BMC} / \mathrm{BW}$, calculated by the computer module, provides a measurement of linear bone density in $\mathrm{cm}^{2}$. The entire depth of the bone, i.e., the distance from top surface to bottom surface of a bone lying flat, is included in this measurement. The BMC, $\mathrm{BW}$, and $\mathrm{BMC} / \mathrm{BW}$ values are recorded in Tables F.1 through F.4.

Bone lengths were measured by placing each of the bones in a longitudinal position along the scan path of the scanner module. Data on these lengths are recorded in Table F.5. 
Fig. F.1 The Norland Digital Bone Densitometer, Model 278, with computer module at left. The densitometer scanner module transports a highly collimated beam of monenergetic gamma rays from a radioactive sealed source ( 125 I) across the bone to be measured. The computer module calculates the values from the resulting absorption curve and displays the results on the screen. A calibration standard is shown on the scanner deck.

Fig. F.2 Printout display of rat femur profile. Measurement results are BMC (bone mineral content-mass) expressed in grams per $\mathrm{cm}, \mathrm{BW}$ (bone width) in $\mathrm{cm}, \mathrm{BMC} / \mathrm{BW}$ in grams per $\mathrm{cm}^{2}$. 


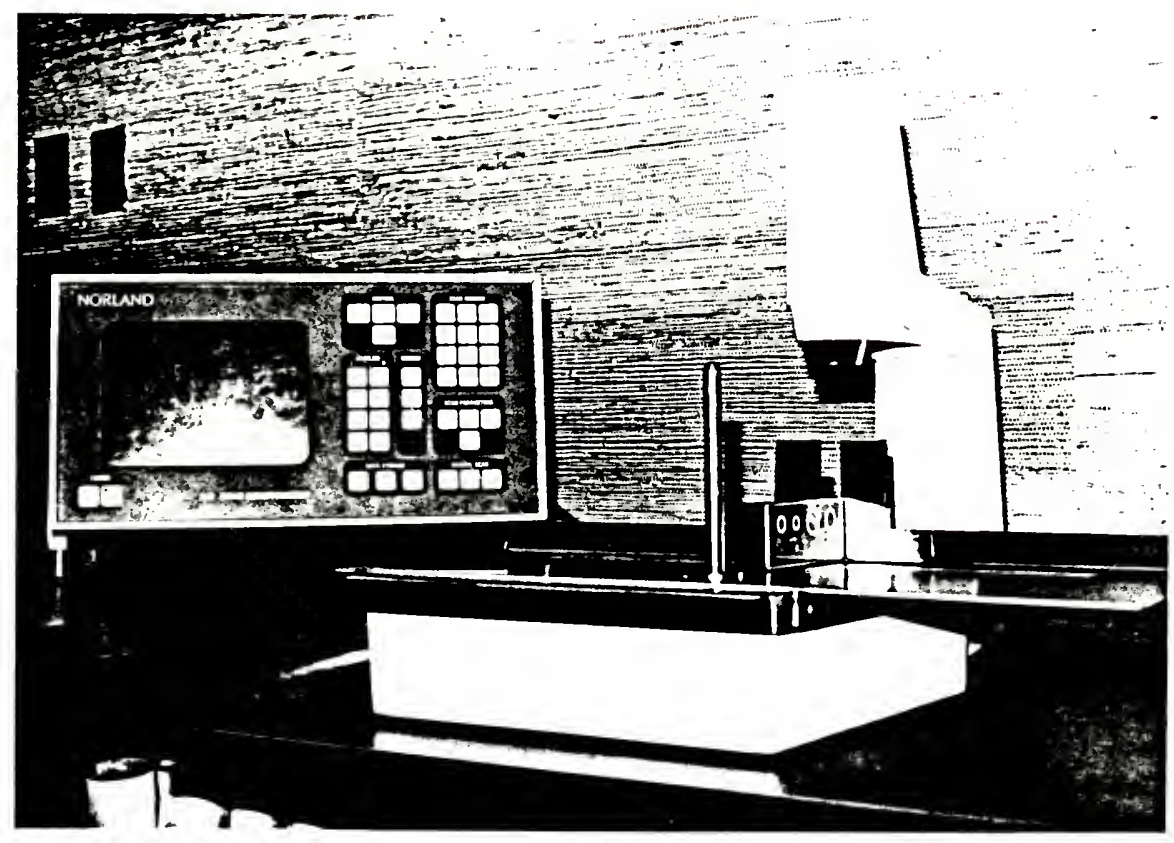

SCAN \# 40032

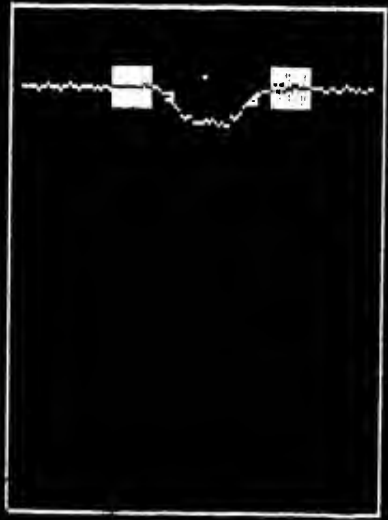

SOURCE

I-125

STO. ERRCR 1. B\%

THRESHOLD 85. $8 \%$

$\mathrm{BMC}=0.070 \mathrm{CR} \mathrm{RH}+\mathrm{S}, \mathrm{CM}$

$\mathrm{g} W=0.313 \mathrm{~cm}$

$\frac{\mathrm{BHC}}{\mathrm{EH}}=0.224$ GRAMS $/ \mathrm{CH}^{2}$

BASELINE $\mathrm{R}=276$ BASELINE $L=276$ 


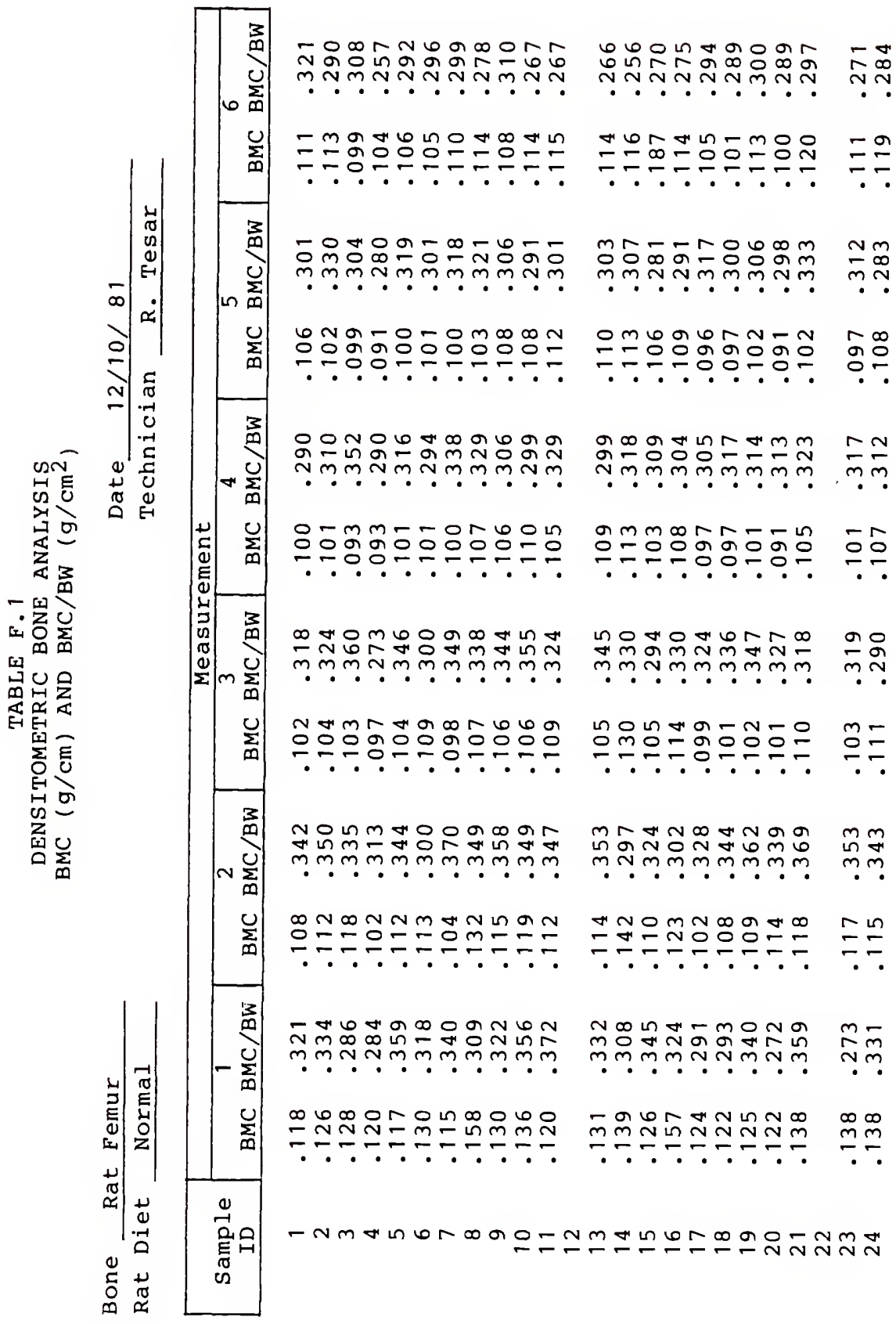




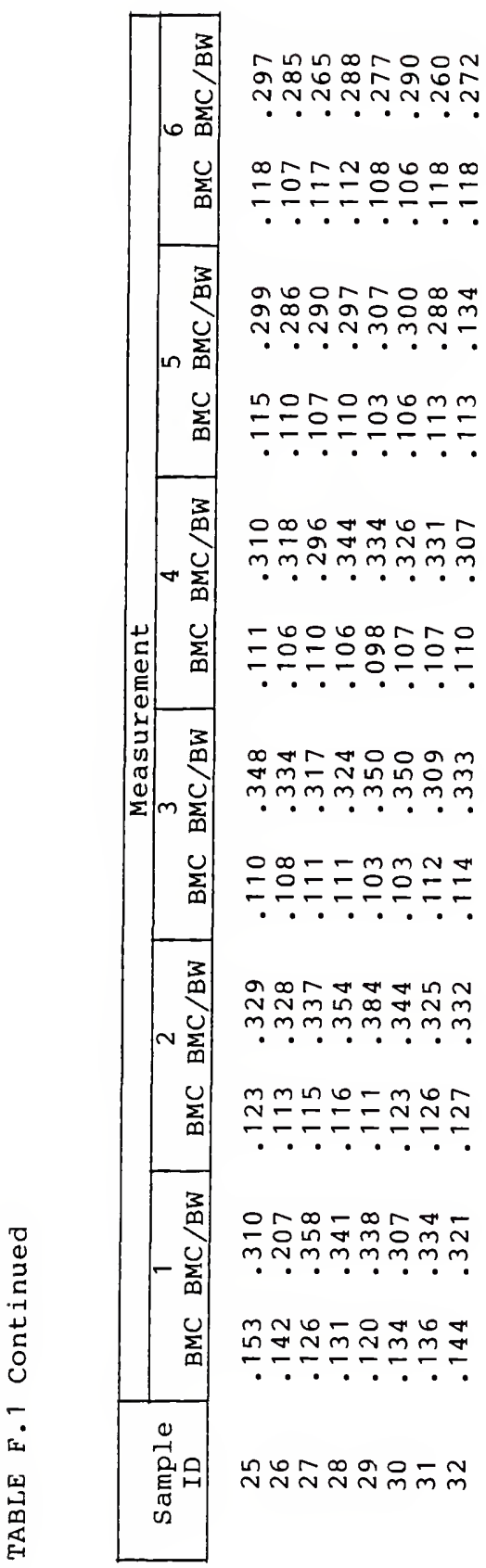




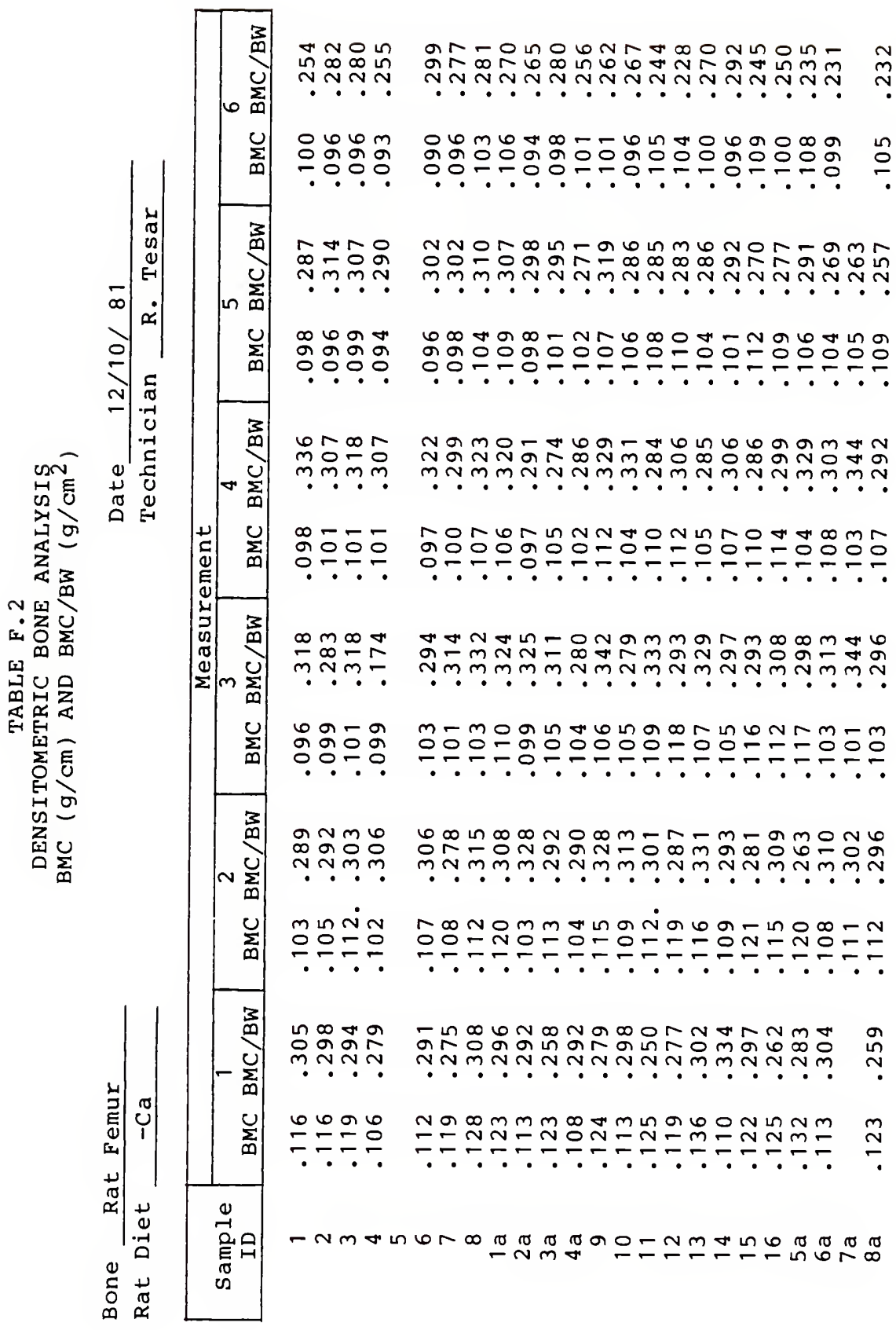




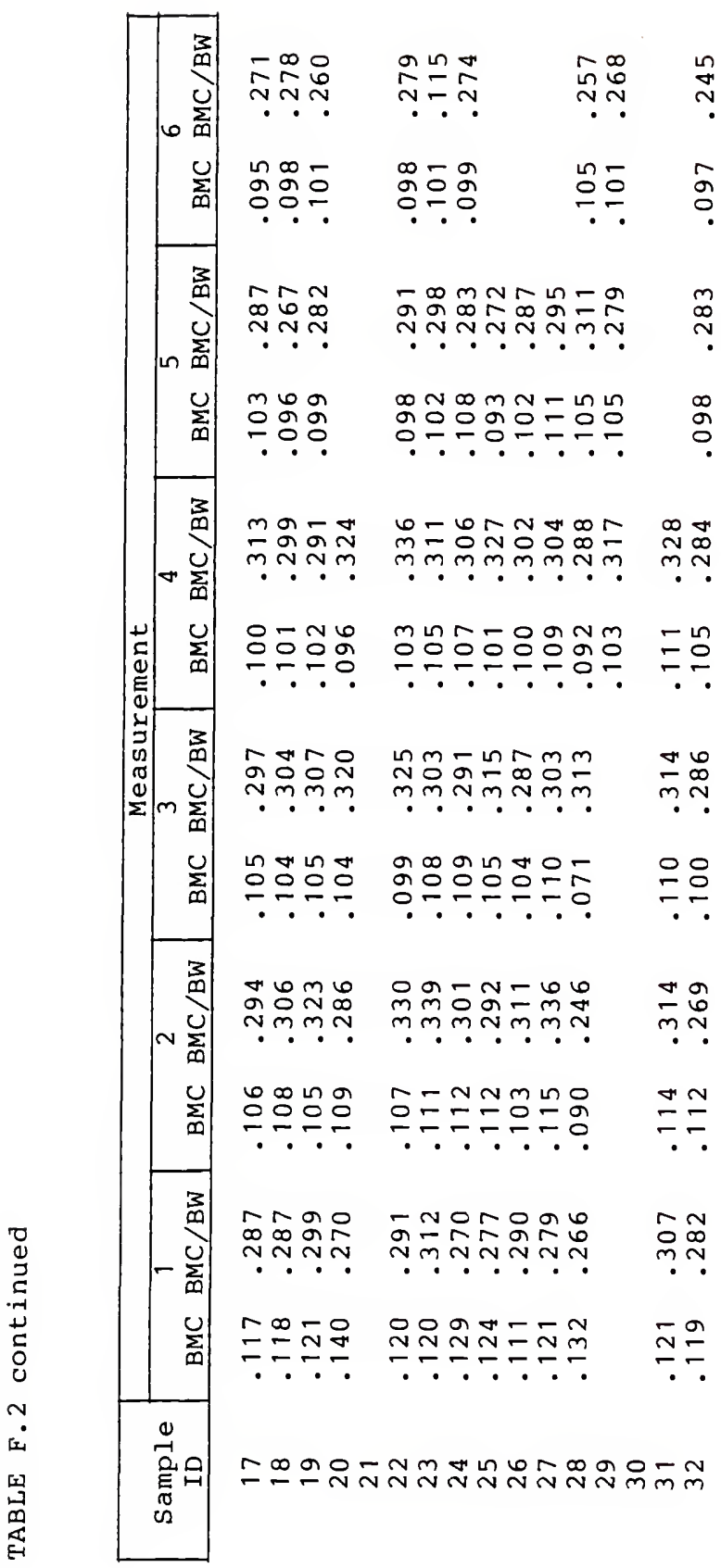




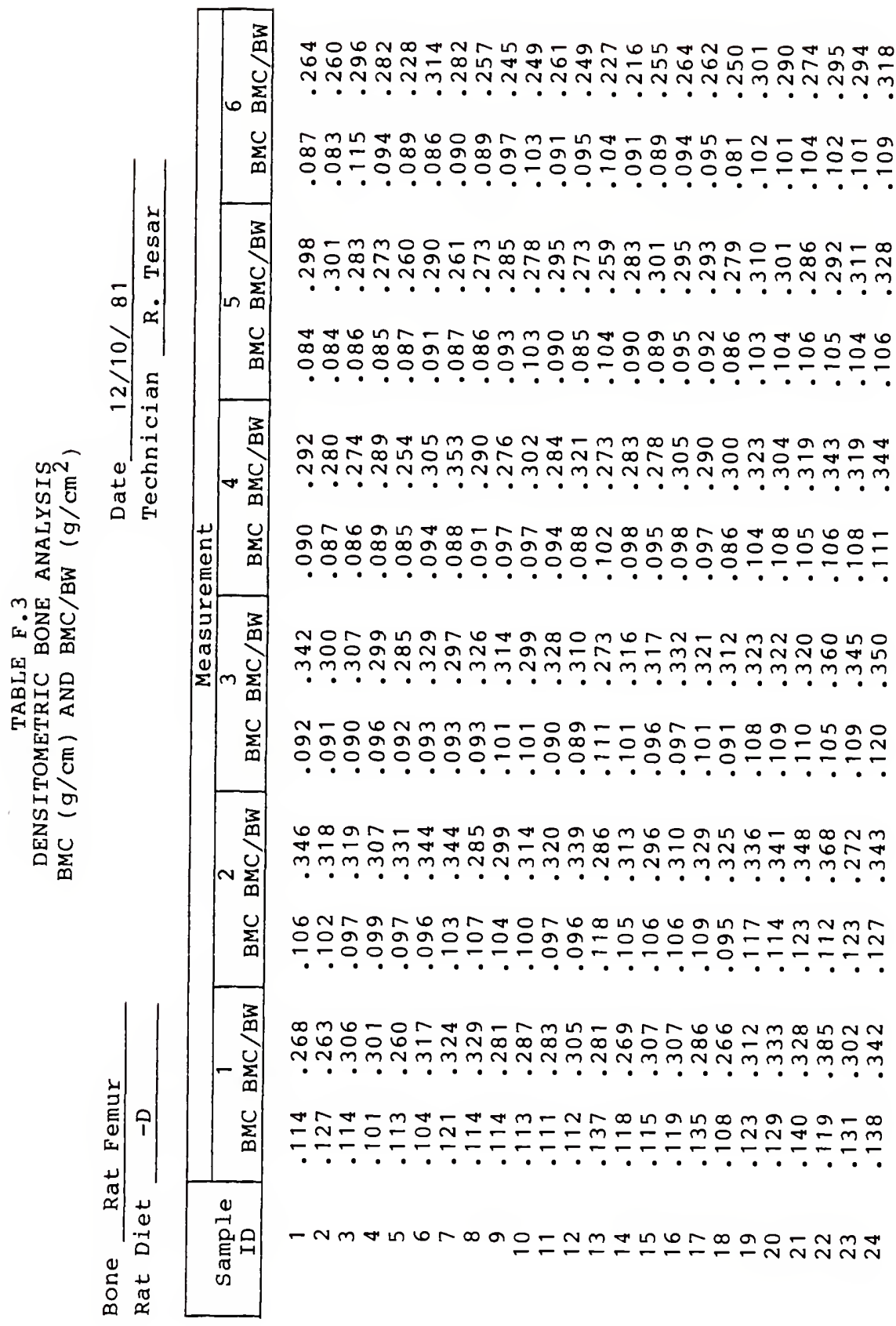




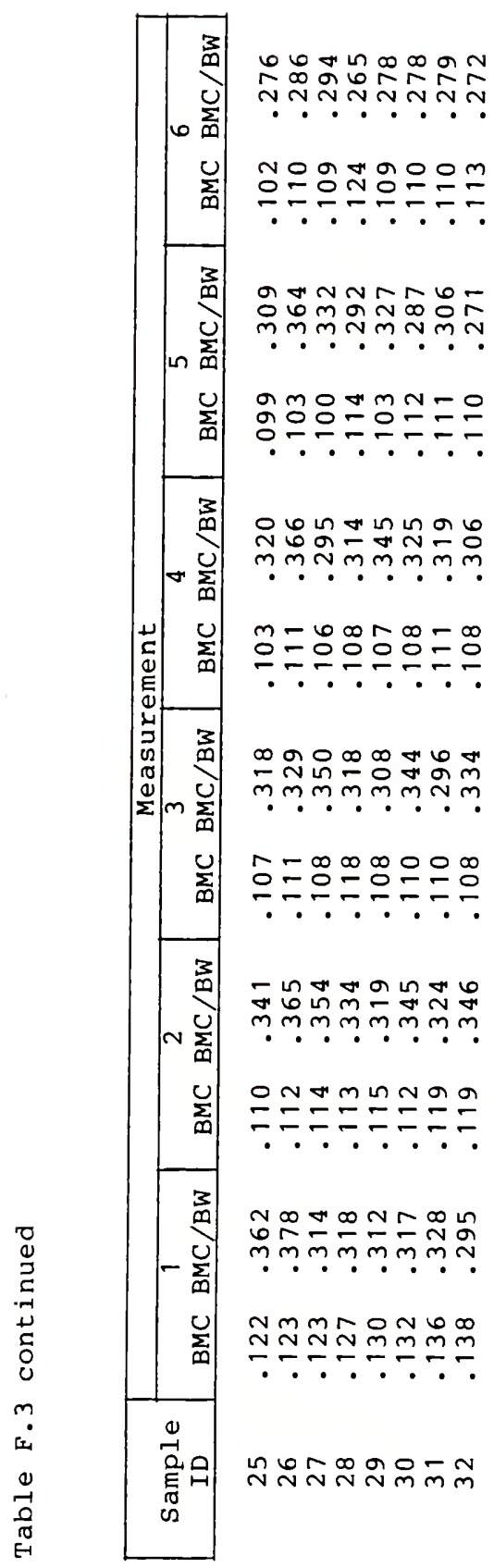




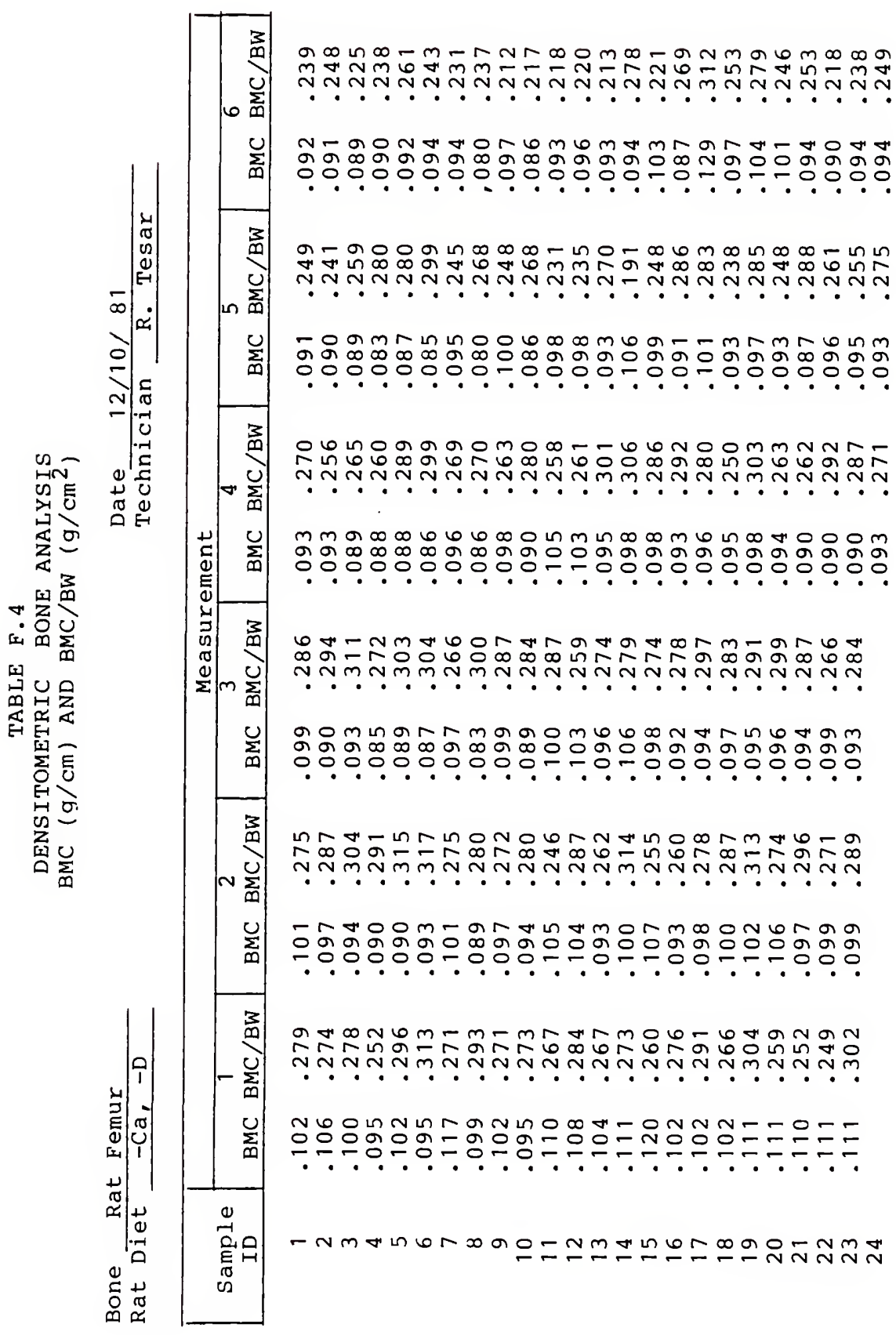




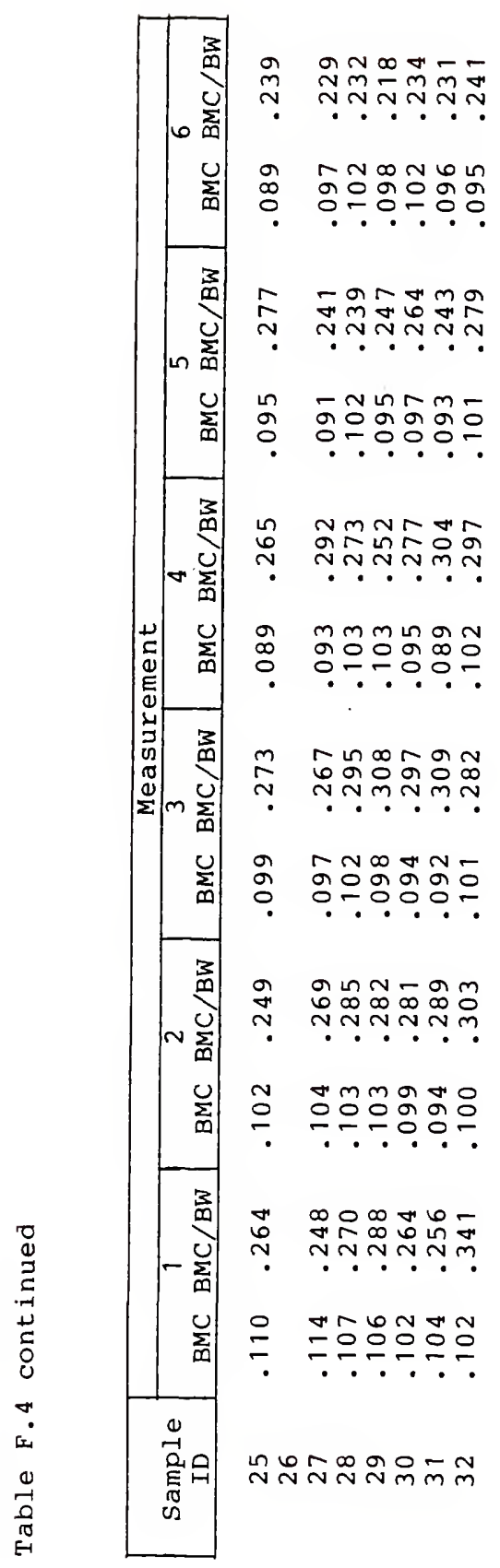


TABLE F. 5

DENSITOMETRIC BONE ANALYSIS

BONE LENGTH ( $\mathrm{cm}$ )

Bone Rat Femur
Threshold Collimator $\frac{1 / 16^{\prime \prime}}{858}$

\begin{tabular}{|c|c|c|c|c|}
\hline $\begin{array}{c}\text { Sample } \\
\text { ID }\end{array}$ & Normal & $-\mathrm{Ca}$ & $-D$ & $-\mathrm{Ca},-\mathrm{D}$ \\
\hline 1 & 3.081 & 3.113 & 3.098 & 3.143 \\
\hline 2 & 3.237 & 3.018 & 3.169 & 3.209 \\
\hline 3 & 3.203 & 3.142 & & 3.118 \\
\hline 4 & 3.207 & 3.097 & 3.118 & 2.994 \\
\hline 5 & 3.244 & & 2.994 & 3.119 \\
\hline 6 & 3.235 & 2.970 & 3.207 & \\
\hline 7 & 3.047 & 2.974 & 3.122 & 3.207 \\
\hline 8 & 3.453 & 3.210 & 3.165 & \\
\hline $1 \mathrm{a}$ & & 3.308 & & \\
\hline $2 a$ & & 3.076 & & \\
\hline $3 a$ & & 2.914 & & \\
\hline $4 a$ & & 3.220 & & \\
\hline 9 & & 3.370 & & \\
\hline 10 & 3.457 & 3.097 & 3.205 & \\
\hline 11 & 3.301 & 3.197 & & \\
\hline 12 & & 3.487 & 3.118 & \\
\hline 13 & 3.563 & 3.234 & 3.292 & \\
\hline 14 & 3.581 & 3.316 & 3.297 & \\
\hline 15 & 3.518 & 3.130 & 3.123 & 3.364 \\
\hline 16 & 3.609 & 3.260 & 3.235 & \\
\hline $5 a$ & & 3.197 & & \\
\hline $\begin{array}{l}6 a \\
7 a\end{array}$ & . & & & \\
\hline $8 a$ & & 3.423 & & \\
\hline 17 & 3.148 & 3.039 & 3.207 & \\
\hline 18 & 3.220 & 3.085 & 3.010 & 3.148 \\
\hline 19 & 3.199 & 3.197 & 3.083 & 3.169 \\
\hline 20 & 3.254 & & 3.100 & 3.201 \\
\hline 21 & 3.337 & 3.082 & 3.138 & 3.109 \\
\hline 22 & & & 3.159 & 3.160 \\
\hline 23 & 3.301 & 2.928 & 3.039 & 3.101 \\
\hline 24 & & 3.222 & 3.163 & \\
\hline 25 & 3.489 & & 3.010 & 3.373 \\
\hline 26 & 3.342 & & 3.163 & \\
\hline 27 & 3.413 & & 3.092 & 3.216 \\
\hline 28 & 3.426 & 3.082 & 3.405 & 3.417 \\
\hline 29 & 3.139 & & 3.159 & 3.292 \\
\hline 30 & 3.342 & & 3.134 & \\
\hline 31 & & & 3.147 & 3.222 \\
\hline 32 & 3.471 & 3.184 & 3.204 & \\
\hline
\end{tabular}


APPENDIX G

BIOMECHANICAL TESTING

One femur from each rat was used in a biomechanical testing procedure (Puhl et al., 1972) to determine torque and deformation values at time of fracture. This testing procedure is based on a dynamic test, with load being applied very rapidly. More reliability of results is expected to be obtained than by use of static methods which would allow creep to occur in the molded ends of the bones.

In preparation, continually keeping the bones moist, both ends of each femur were embedded in soft, pliable methyl methacrylate, placed in a special mold, and allowed to harden. After the bones were removed from the mold, they were individually mounted in the torsional testing machine shown in Fig. G.1. The specimens were loaded to fracture in external torsion about their longitudinal axis. A torsional pendulum provided the load by engaging the bone midway in its free fall.

A coupled oscilloscope traced out a torque-deflection diagram as each bone was twisted to fracture. A permanent record of each torque-deflection trace was obtained by an electronically triggered camera. The photographs provided a means for determining the value of torque $(\mathrm{kg}-\mathrm{cm})$ and deformation, or twist angle (degrees), as shown by representations in Fig. G.2. Values are recorded in Tables G.1 through G.4. 
Fig. G.1 The Rapid Loading Torsional Testing Machine, with the recording oscilloscope at left. The bone specimen is loaded in dynamic torsion between the headstock and tailstock of the machine, indicated by the arrow. Biomechanics Laboratory, University of Florida.

1. Normal Diet

3. $-D$
2. $-\mathrm{Ca}$

4. $-\mathrm{Ca},-\mathrm{D}$

Fig. G.2 Representative torque - deflection curves. The horizontal scale is 10 degrees/division (deformation); the vertical scale is $1 \mathrm{~kg}$ force-cm/division (torque). 

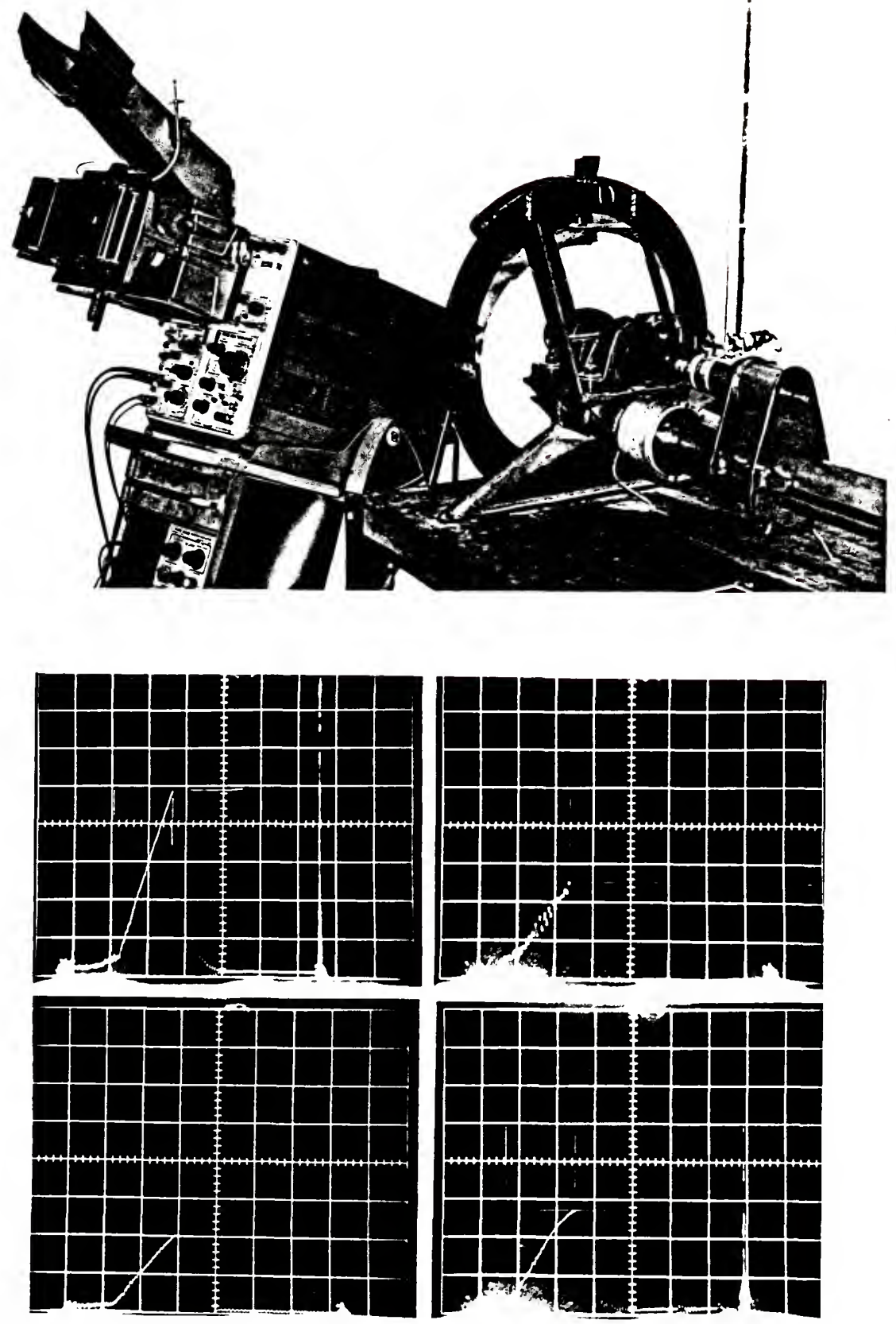
TABLE G. 1

BIOMECHANICAL PROPERTIES

NORMAL DIET

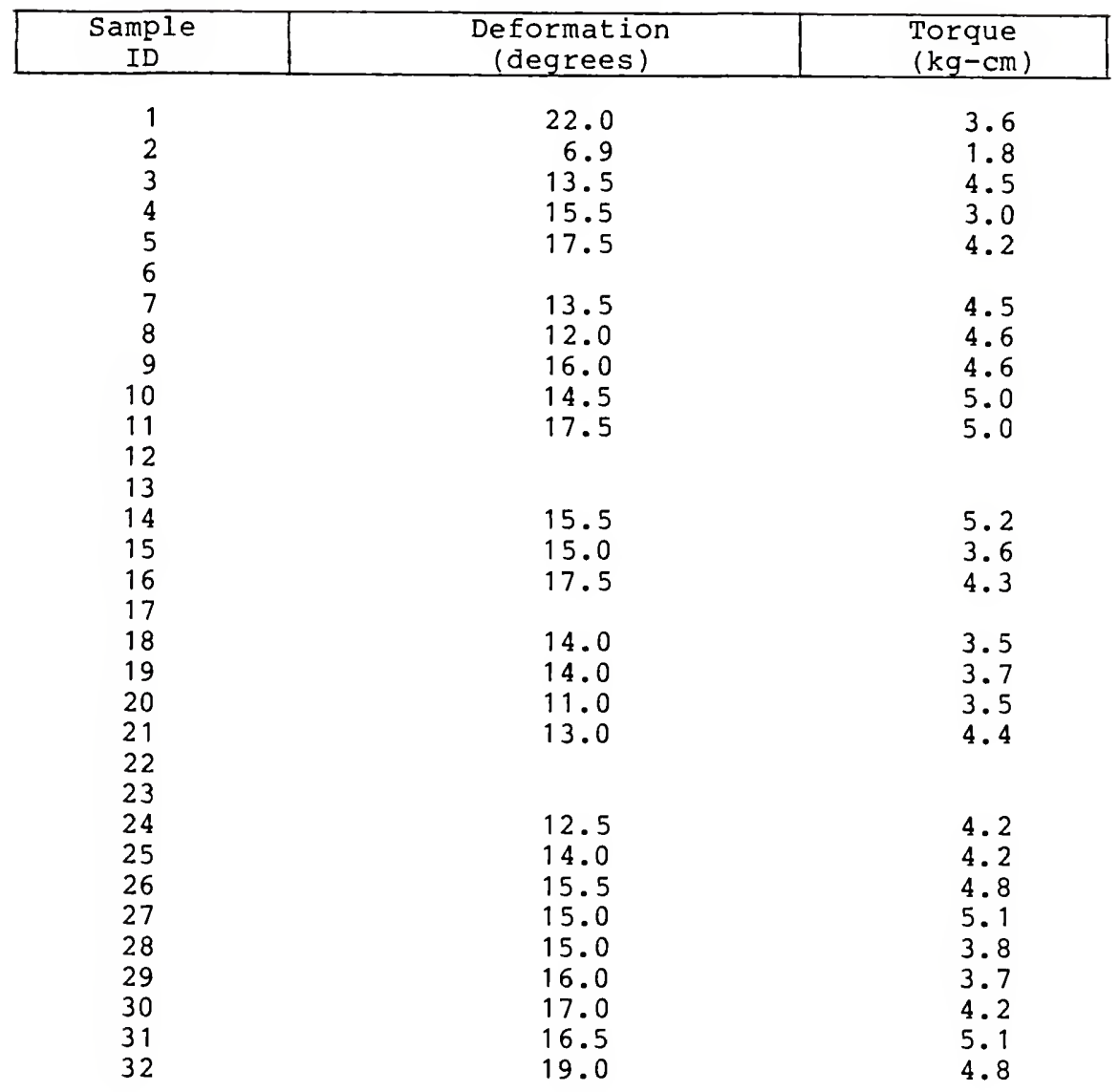


TABLE G. 2

BIOMECHANICAL PROPERTIES

-CA DIET

\begin{tabular}{|c|c|c|}
\hline $\begin{array}{l}\text { Sample } \\
\text { ID }\end{array}$ & $\begin{array}{c}\text { Deformation } \\
\text { (degrees) }\end{array}$ & $\begin{array}{l}\text { Torque } \\
(\mathrm{kg}-\mathrm{cm})\end{array}$ \\
\hline $\begin{array}{r}1 \\
2 \\
3 \\
4 \\
5 \\
6 \\
7 \\
8 \\
1 a \\
2 a \\
3 a \\
4 a \\
9 \\
10 \\
11 \\
12 \\
13 \\
14 \\
15 \\
16 \\
5 a \\
6 a \\
7 a \\
8 a \\
17 \\
18 \\
19 \\
20 \\
21 \\
22 \\
23 \\
24 \\
25 \\
26 \\
27 \\
28 \\
29 \\
30 \\
31 \\
32\end{array}$ & $\begin{array}{l}15.0 \\
13.5 \\
12.0 \\
17.0 \\
12.5 \\
21.0 \\
17.5 \\
16.0 \\
10.5 \\
19.5 \\
16.5 \\
20.5 \\
22.5 \\
18.5 \\
16.5 \\
14.5 \\
16.0 \\
23.5 \\
13.5 \\
21.5\end{array}$ & $\begin{array}{l}2.4 \\
3.0 \\
2.4 \\
2.4 \\
2.2 \\
3.0 \\
2.2 \\
2.6 \\
2.7 \\
2.5 \\
2.4 \\
2.1 \\
2.5 \\
1.8 \\
2.1 \\
2.4 \\
3.3 \\
2.6 \\
3.0 \\
2.4\end{array}$ \\
\hline
\end{tabular}


TABLE G. 3

BIOMECHANICAL PROPERTIES

-D DIET

\begin{tabular}{|c|c|c|}
\hline $\begin{array}{c}\text { Sample } \\
\text { ID }\end{array}$ & $\begin{array}{c}\text { Deformation } \\
\text { (degrees) }\end{array}$ & $\begin{array}{l}\text { Torque } \\
(\mathrm{kg}-\mathrm{cm})\end{array}$ \\
\hline 1 & 12.0 & 2.2 \\
\hline 2 & 15.5 & 2.6 \\
\hline 3 & 21.0 & 2.8 \\
\hline 4 & 13.5 & 3.1 \\
\hline 5 & 15.5 & 2.7 \\
\hline 6 & 15.5 & 1.5 \\
\hline 7 & 23.0 & 3.0 \\
\hline 8 & 20.0 & 3.0 \\
\hline 9 & 14.0 & 3.2 \\
\hline 10 & 17.5 & 4.0 \\
\hline 11 & & \\
\hline 12 & 17.0 & 2.1 \\
\hline 13 & 16.0 & 3.6 \\
\hline 14 & 25.0 & 3.2 \\
\hline 15 & 16.0 & 2.4 \\
\hline 16 & 15.0 & 3.0 \\
\hline 17 & 17.0 & 3.6 \\
\hline 18 & 14.0 & 2.7 \\
\hline 19 & 16.5 & 2.8 \\
\hline 20 & 19.0 & 3.8 \\
\hline 21 & 14.0 & 2.9 \\
\hline 22 & 16.0 & 2.9 \\
\hline $\begin{array}{l}23 \\
24\end{array}$ & 17.0 & 2.6 \\
\hline 25 & 17.5 & 2.6 \\
\hline 26 & 23.0 & 2.6 \\
\hline 27 & 21.0 & 2.4 \\
\hline 28 & 10.5 & 2.4 \\
\hline 29 & 15.5 & 3.0 \\
\hline 30 & 16.5 & 3.2 \\
\hline $\begin{array}{l}31 \\
32\end{array}$ & 13.5 & \\
\hline & 16.0 & 1.7 \\
\hline
\end{tabular}


TABLE G. 4

BIOMECHANICAL PROPERTIES

-CA, -D DIET

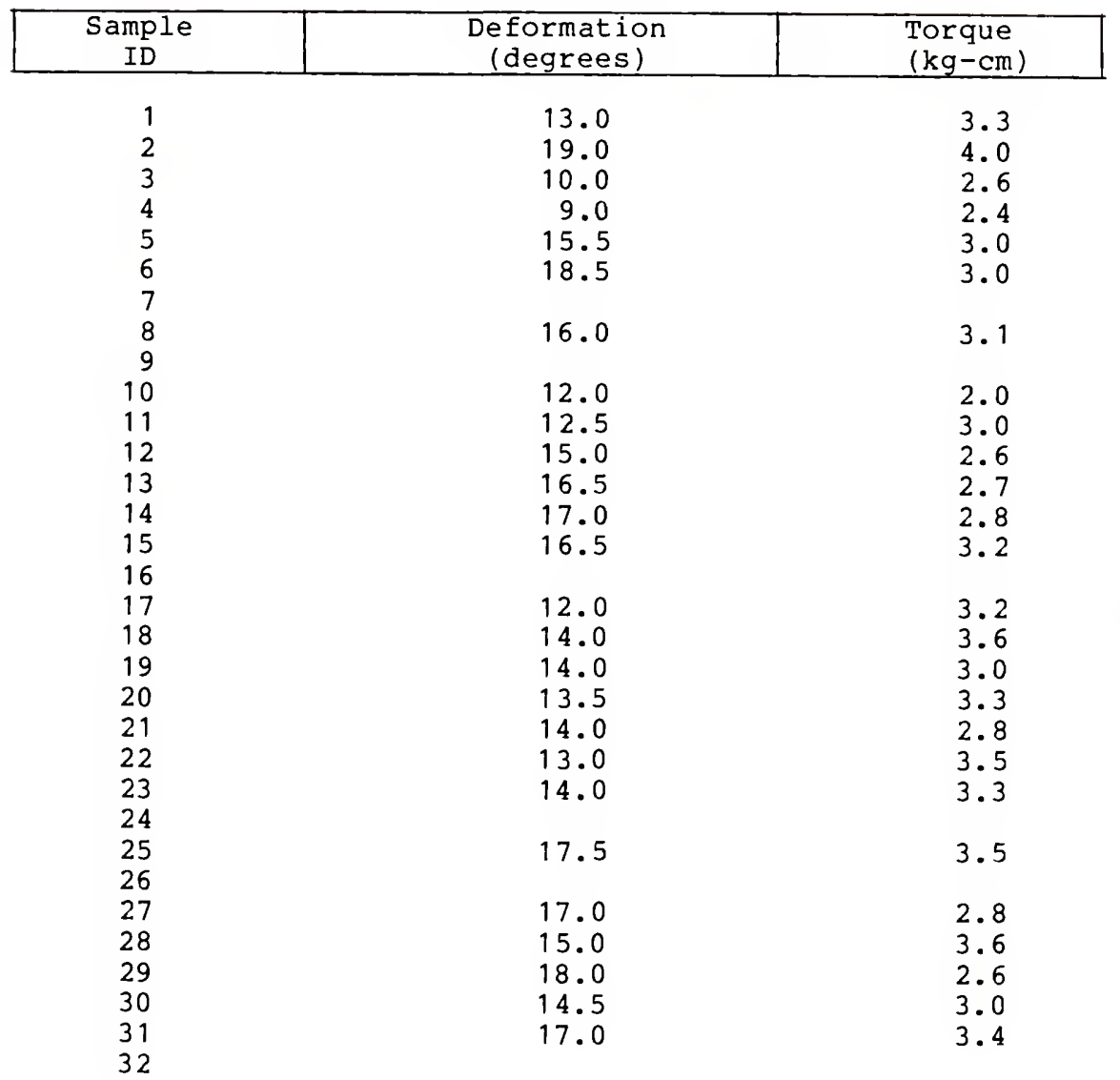


APPENDIX H

BONE ASH ANALYSIS

\section{Ashing Procedure ${ }^{1}$}

One femur from each rat was dried at $100^{\circ} \mathrm{C}$ for 24 hours. After cooling, each bone was wrapped in cloth and labeled. Fat was removed by the ether extraction in a Soxhlet extractor for 36 hours. After extraction, the bones were placed under a hood until the odor of ether was no longer detectable. The bone samples were then placed in an oven to dry at $100^{\circ} \mathrm{C}$ for 24 hours.

Clean, demineralized crucibles were placed in a drying oven $\left(100^{\circ} \mathrm{C}\right)$ for two hours. The crucibles were removed from the oven and cooled in a dessicator for two hours. The crucibles were then weighed to four decimal places on a digital anlytical balance. While on the balance, a bone sample was weighed into each crucible.

Crucibles containing the dry samples were placed in a muffle furnace and the temperature $\left(200^{\circ} \mathrm{C}\right.$ to begin) was rasied $100^{\circ}$ every hour until $550^{\circ} \mathrm{C}$ was reached. Ashing proceeded overnight. The crucibles were removed from the furnace after they cooled partially to an oven at $100^{\circ} \mathrm{C}$. After one hour,

$1_{\text {Fick et al., } 1979}$ 
they were removed to dessicators to cool for two hours. The crucibles and bone ash were then weighed. The of ash of dry, fat-free bone was calculated for each sample. Recorded weights and 8 ash are found in Tables H. 1 through H.4. 


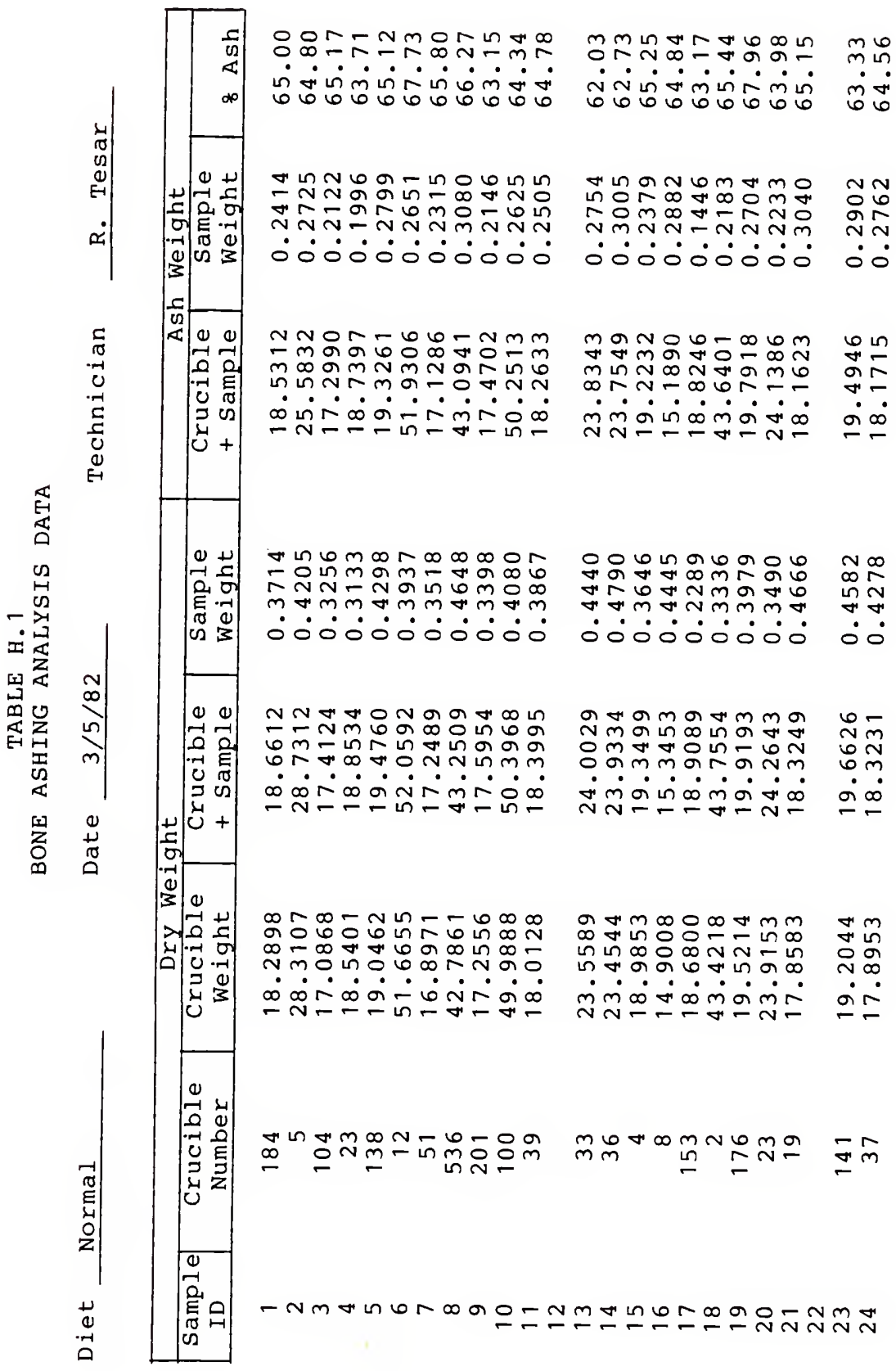




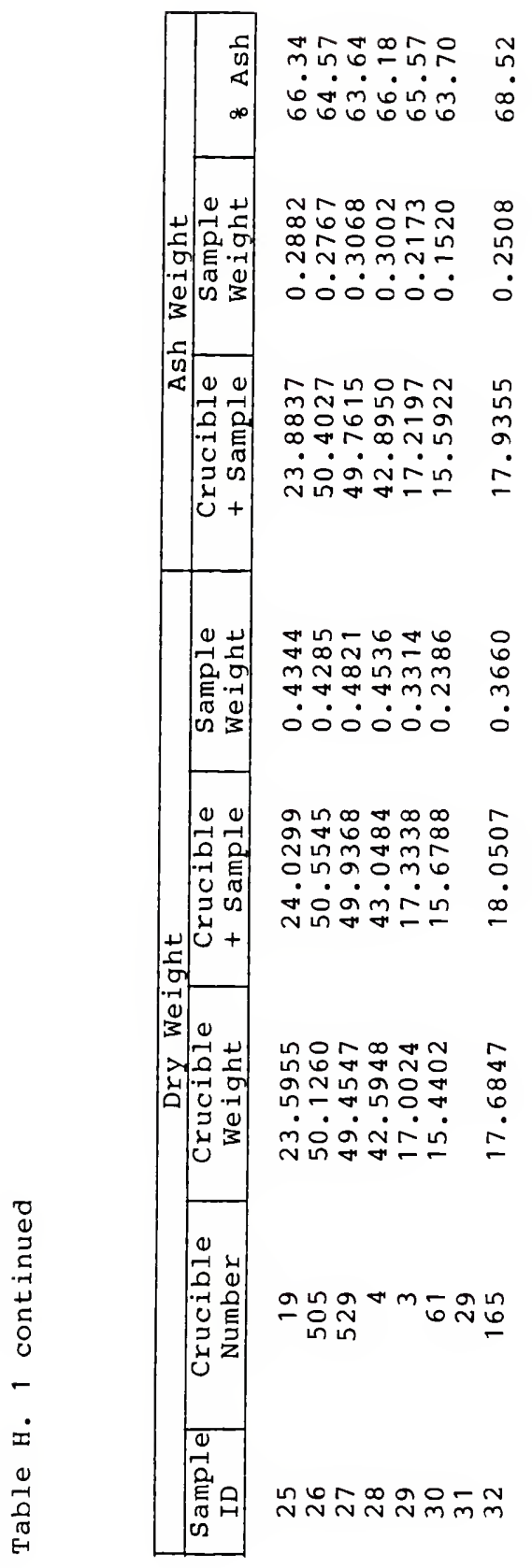




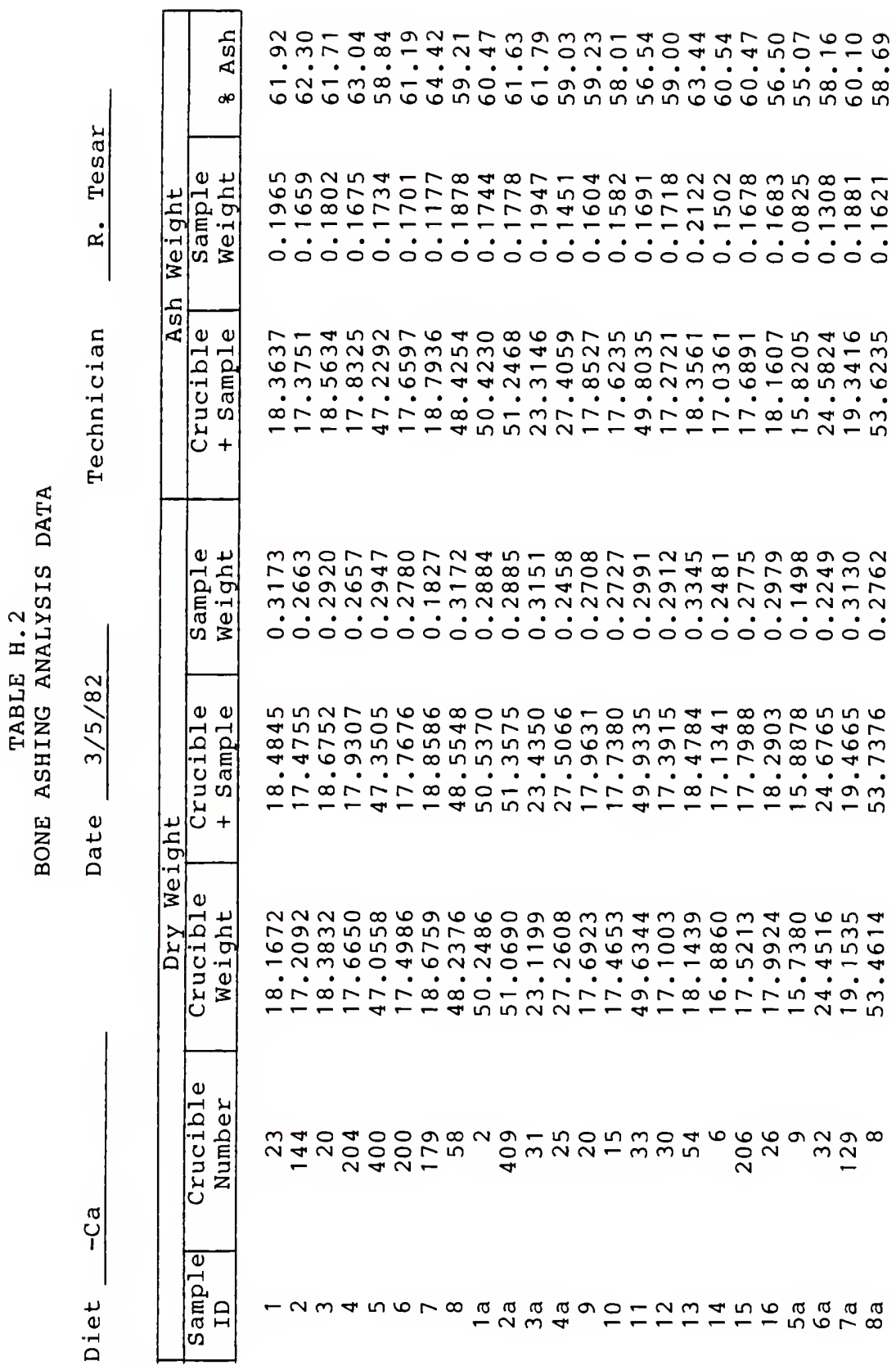




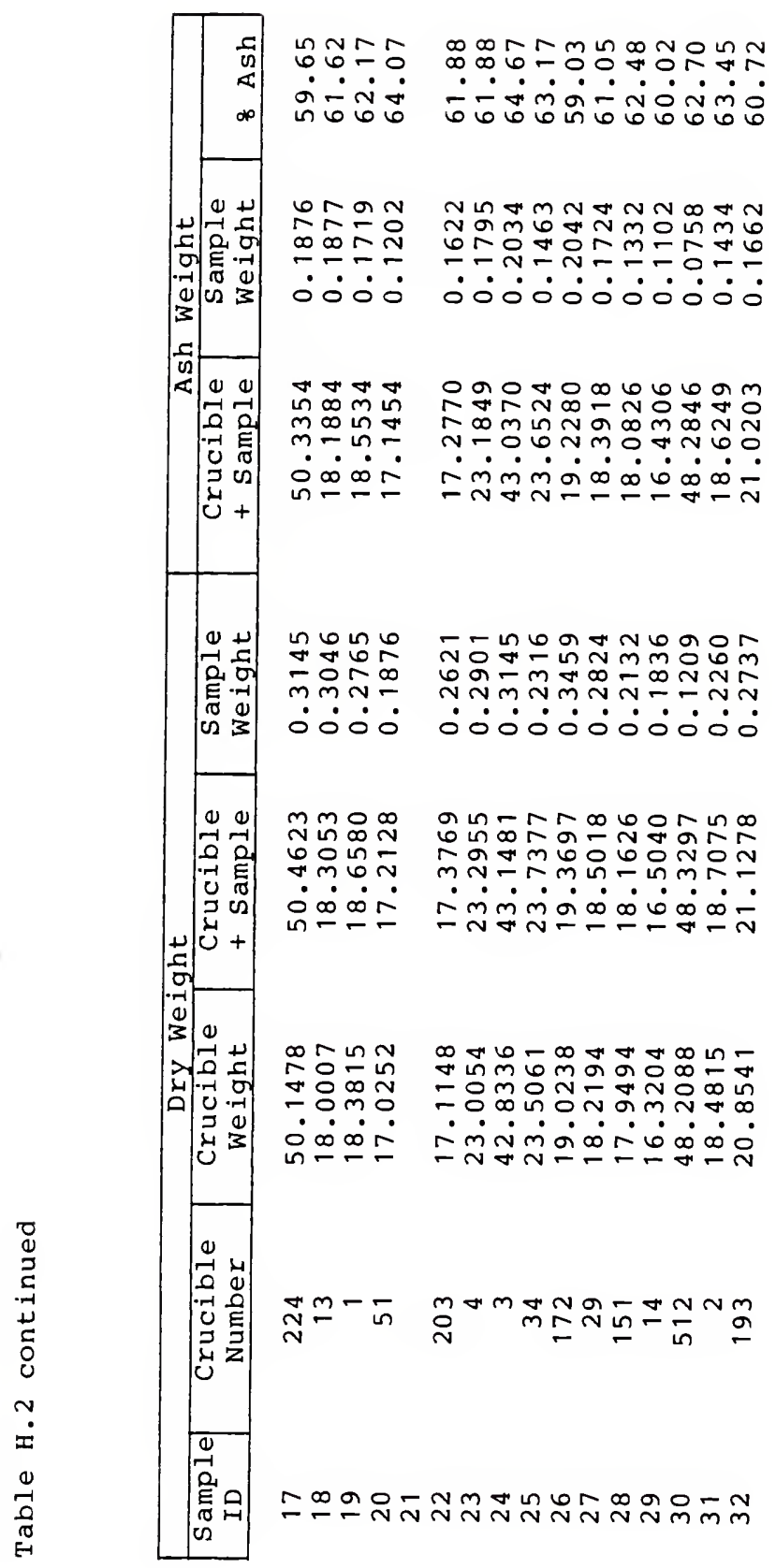




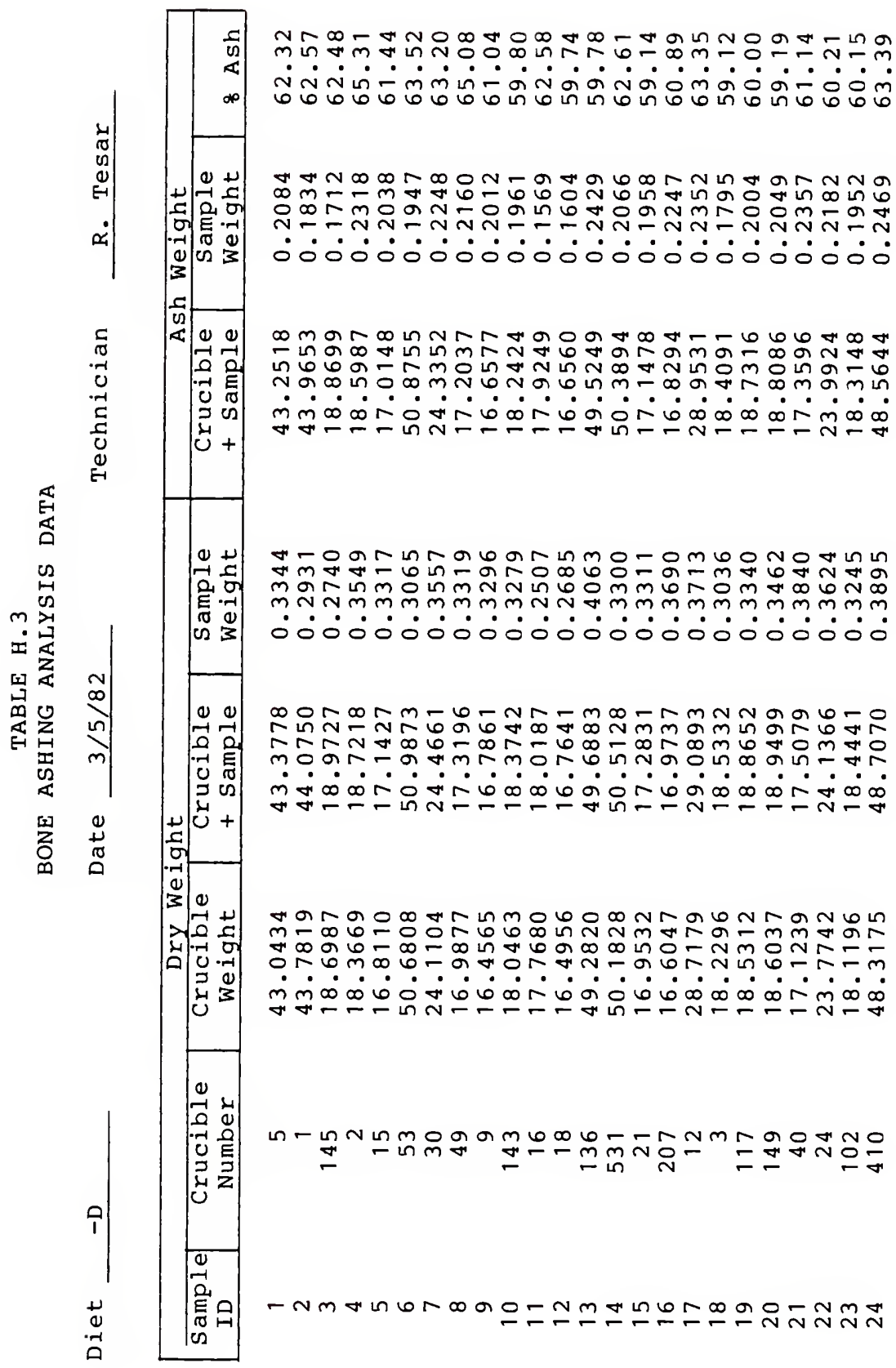




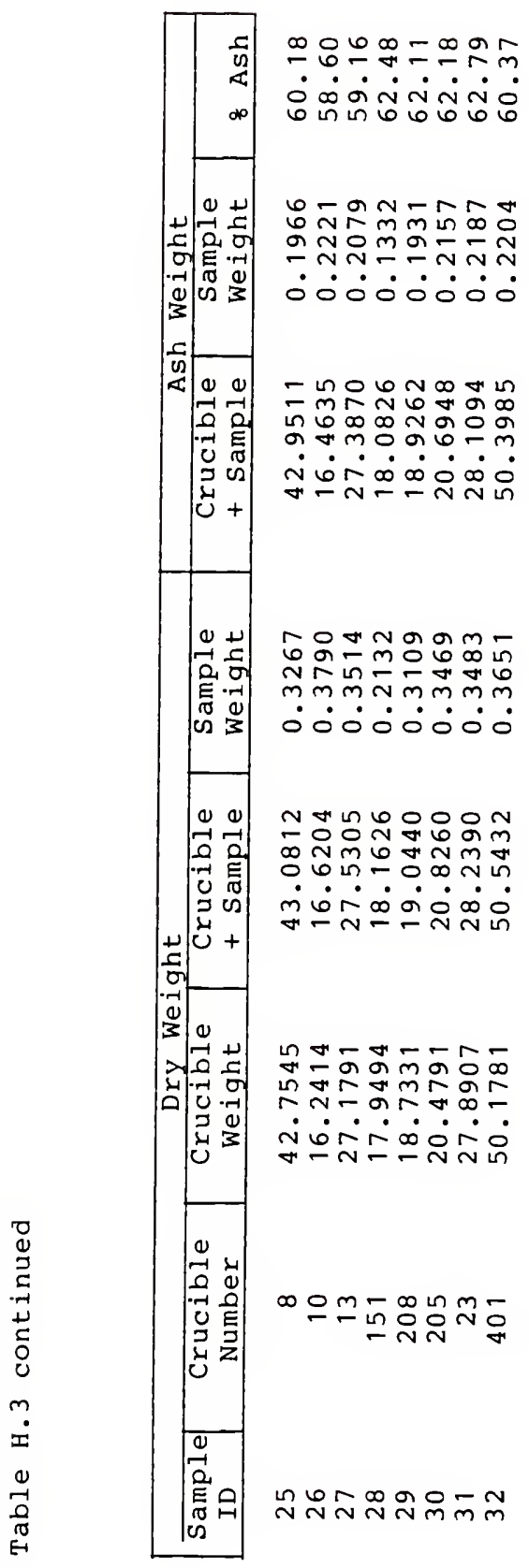




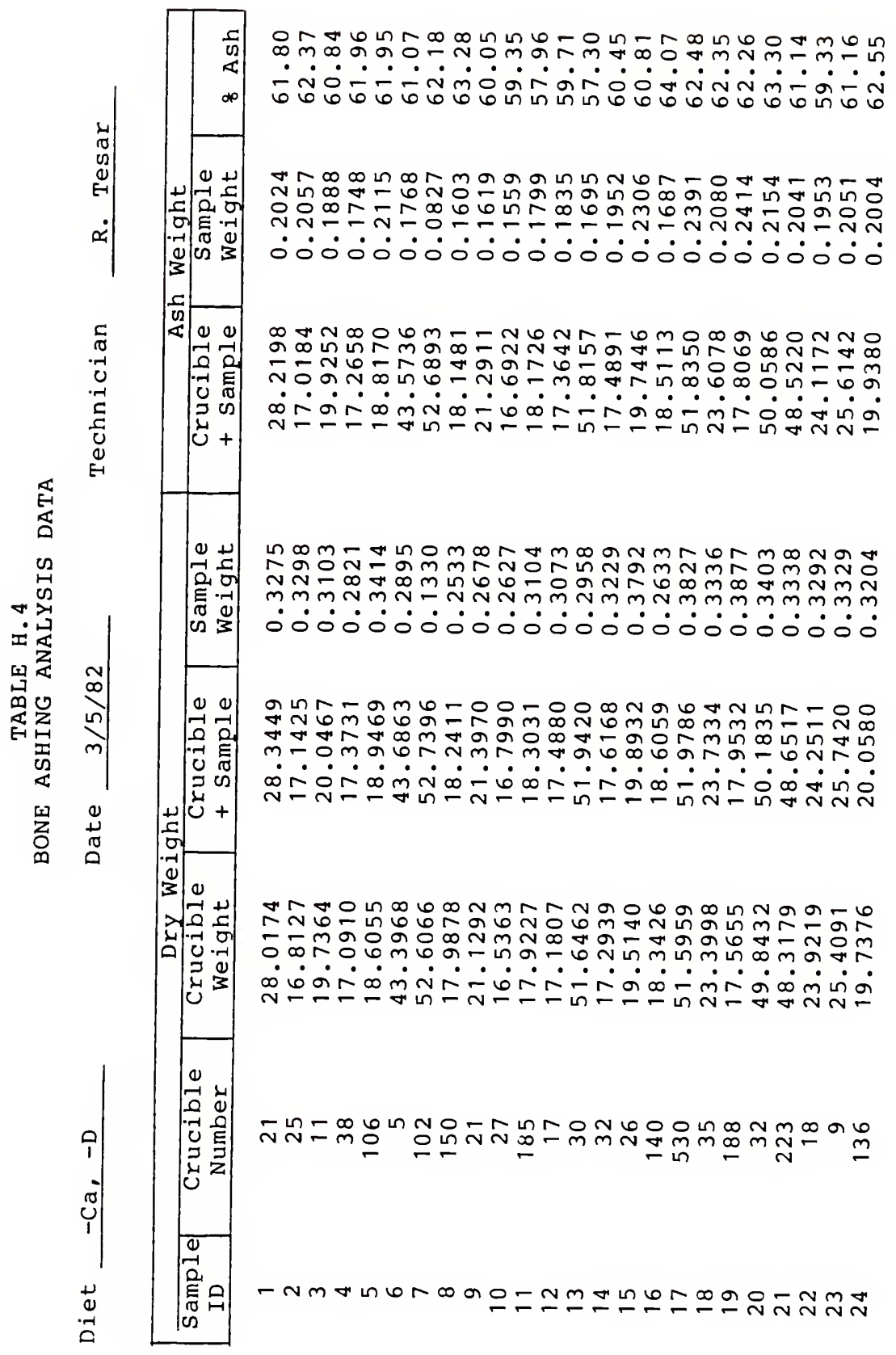




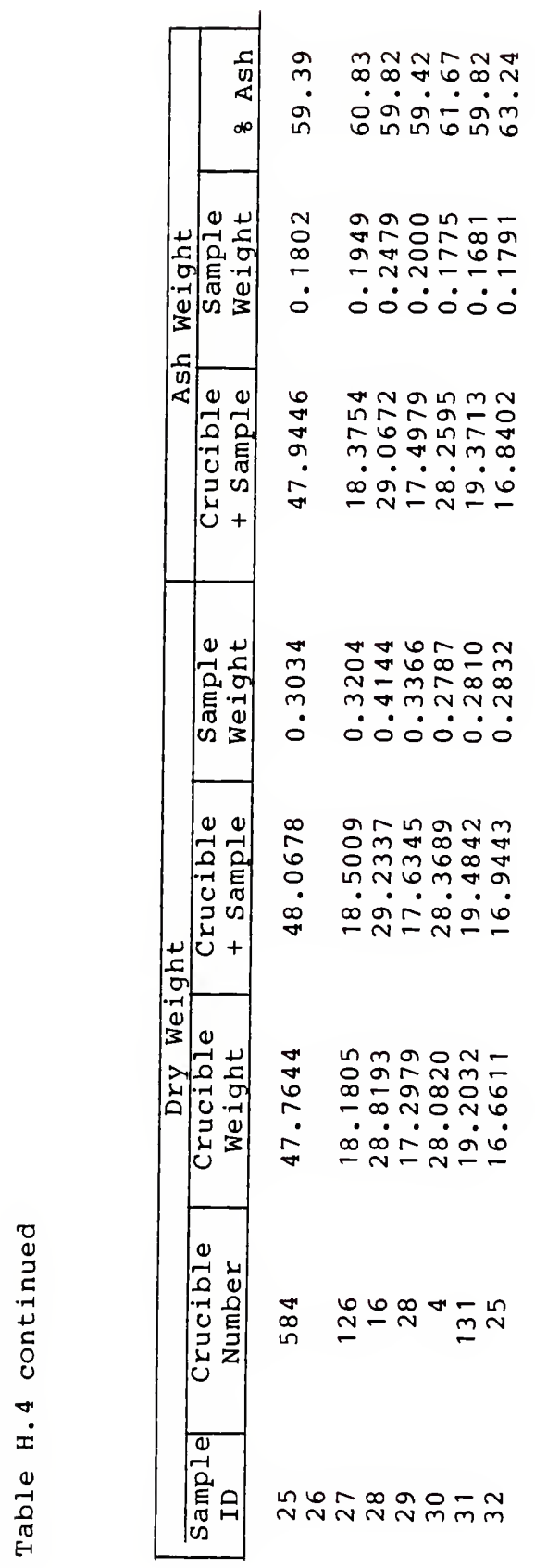


APPENDIX I

MAST CELLS

TABLE I. 1

MAST CELL COUNT--VAGINAL TISSUE

NORMAL DIET

\begin{tabular}{|c|c|c|c|c|c|}
\hline \multirow{2}{*}{$\begin{array}{r}\text { Rat } \\
\text { ID } \\
\end{array}$} & \multicolumn{5}{|c|}{ Section } \\
\hline & 1 & 2 & 3 & 4 & 5 \\
\hline 1 & $\begin{array}{l}6 \\
1 \\
3 \\
6 \\
2\end{array}$ & $\begin{array}{l}5 \\
4 \\
5 \\
3 \\
4\end{array}$ & $\begin{array}{r}14 \\
3 \\
5 \\
2 \\
5\end{array}$ & $\begin{array}{r}19 \\
8 \\
2 \\
6 \\
6\end{array}$ & $\begin{array}{r}2 \\
2 \\
3 \\
9 \\
10\end{array}$ \\
\hline 2 & $\begin{array}{r}5 \\
12 \\
5 \\
4 \\
4\end{array}$ & $\begin{array}{r}11 \\
10 \\
5 \\
8 \\
6\end{array}$ & $\begin{array}{l}1 \\
6 \\
4 \\
2 \\
6\end{array}$ & $\begin{array}{l}7 \\
2 \\
6 \\
6 \\
9\end{array}$ & $\begin{array}{l}8 \\
4 \\
2 \\
4 \\
2\end{array}$ \\
\hline 3 & $\begin{array}{r}4 \\
5 \\
8 \\
6 \\
21\end{array}$ & $\begin{array}{r}6 \\
5 \\
14 \\
2 \\
17\end{array}$ & $\begin{array}{r}5 \\
7 \\
8 \\
16 \\
3\end{array}$ & $\begin{array}{r}4 \\
8 \\
3 \\
11 \\
21\end{array}$ & $\begin{array}{r}3 \\
3 \\
2 \\
3 \\
13\end{array}$ \\
\hline 4 & $\begin{array}{l}6 \\
8 \\
4 \\
4 \\
4\end{array}$ & $\begin{array}{l}3 \\
2 \\
3 \\
9 \\
7\end{array}$ & $\begin{array}{l}1 \\
5 \\
8 \\
4 \\
2\end{array}$ & $\begin{array}{l}3 \\
2 \\
3 \\
3 \\
4\end{array}$ & $\begin{array}{l}5 \\
2 \\
2 \\
6 \\
4\end{array}$ \\
\hline 5 & $\begin{array}{r}6 \\
2 \\
6 \\
6 \\
28\end{array}$ & $\begin{array}{r}9 \\
3 \\
9 \\
12 \\
11\end{array}$ & $\begin{array}{r}3 \\
4 \\
13 \\
9 \\
2\end{array}$ & $\begin{array}{r}9 \\
18 \\
16 \\
7 \\
10\end{array}$ & $\begin{array}{r}12 \\
5 \\
9 \\
8 \\
24\end{array}$ \\
\hline 6 & $\begin{array}{r}2 \\
3 \\
1 \\
11 \\
2\end{array}$ & $\begin{array}{l}4 \\
4 \\
7 \\
6 \\
7\end{array}$ & $\begin{array}{r}11 \\
2 \\
5 \\
3 \\
5\end{array}$ & $\begin{array}{l}3 \\
3 \\
4 \\
5 \\
4\end{array}$ & $\begin{array}{l}6 \\
1 \\
8 \\
3 \\
2\end{array}$ \\
\hline
\end{tabular}


Table I. 1 continued

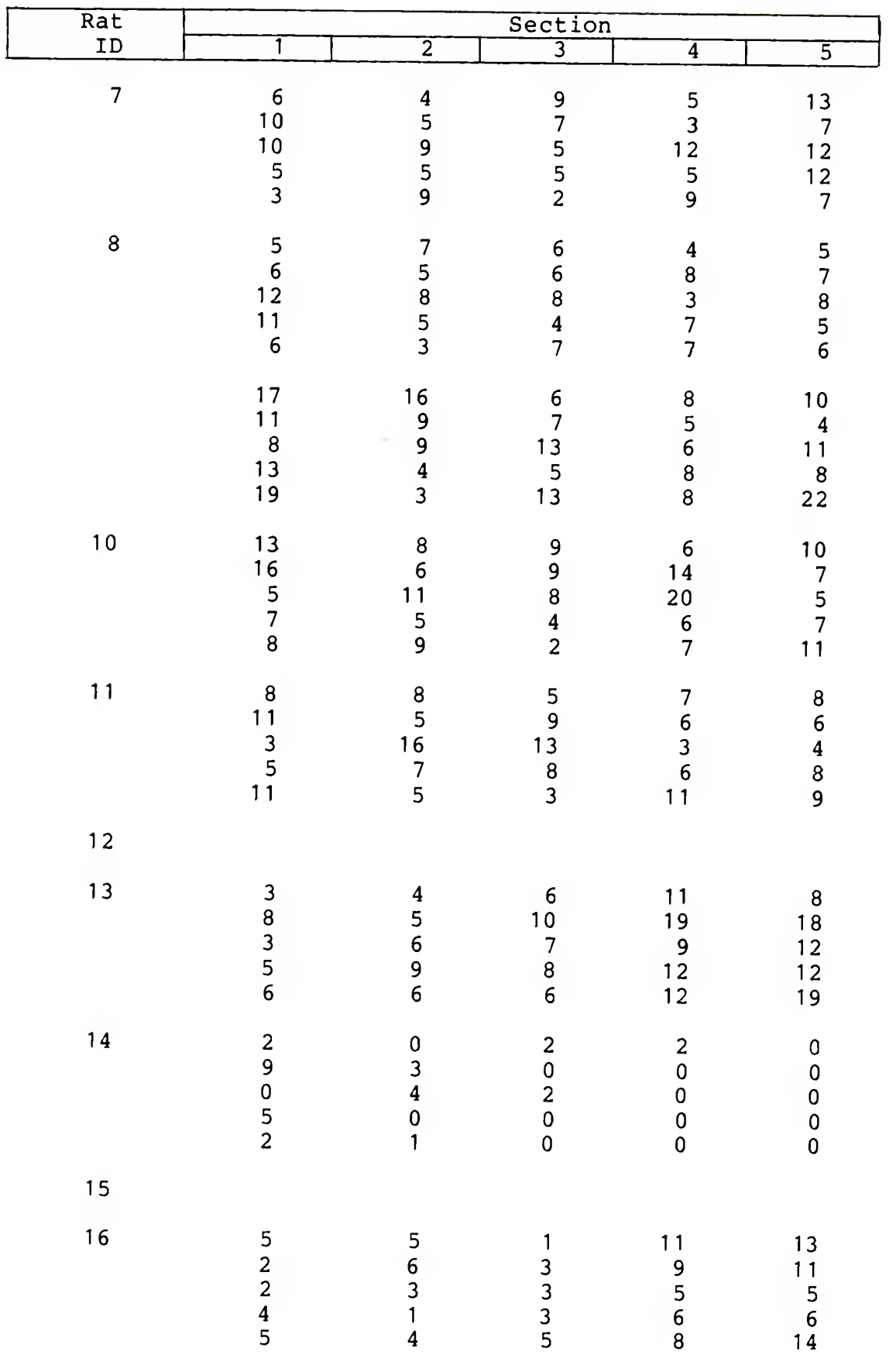


Table I. 1 continued

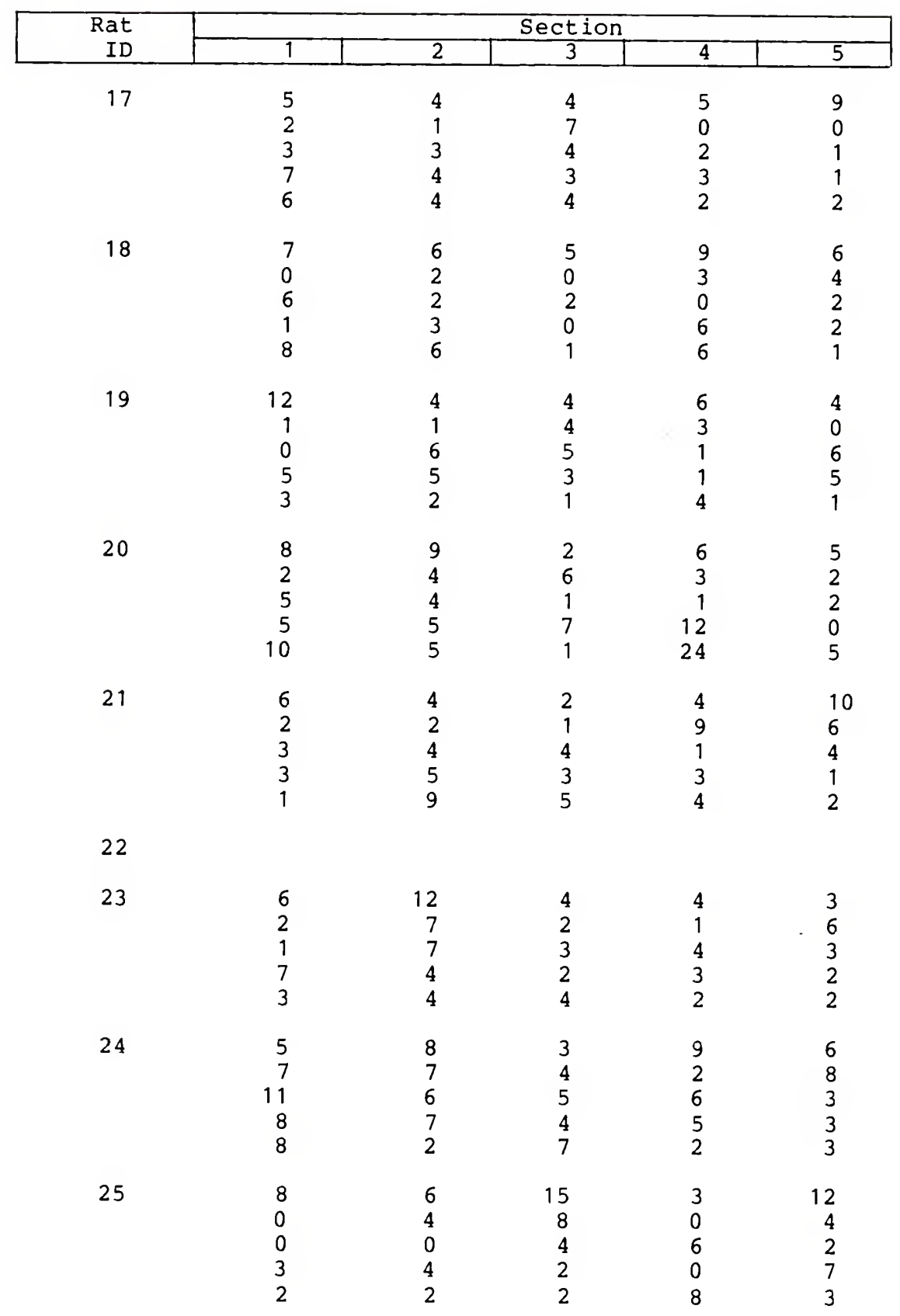


Table I. 1 continued

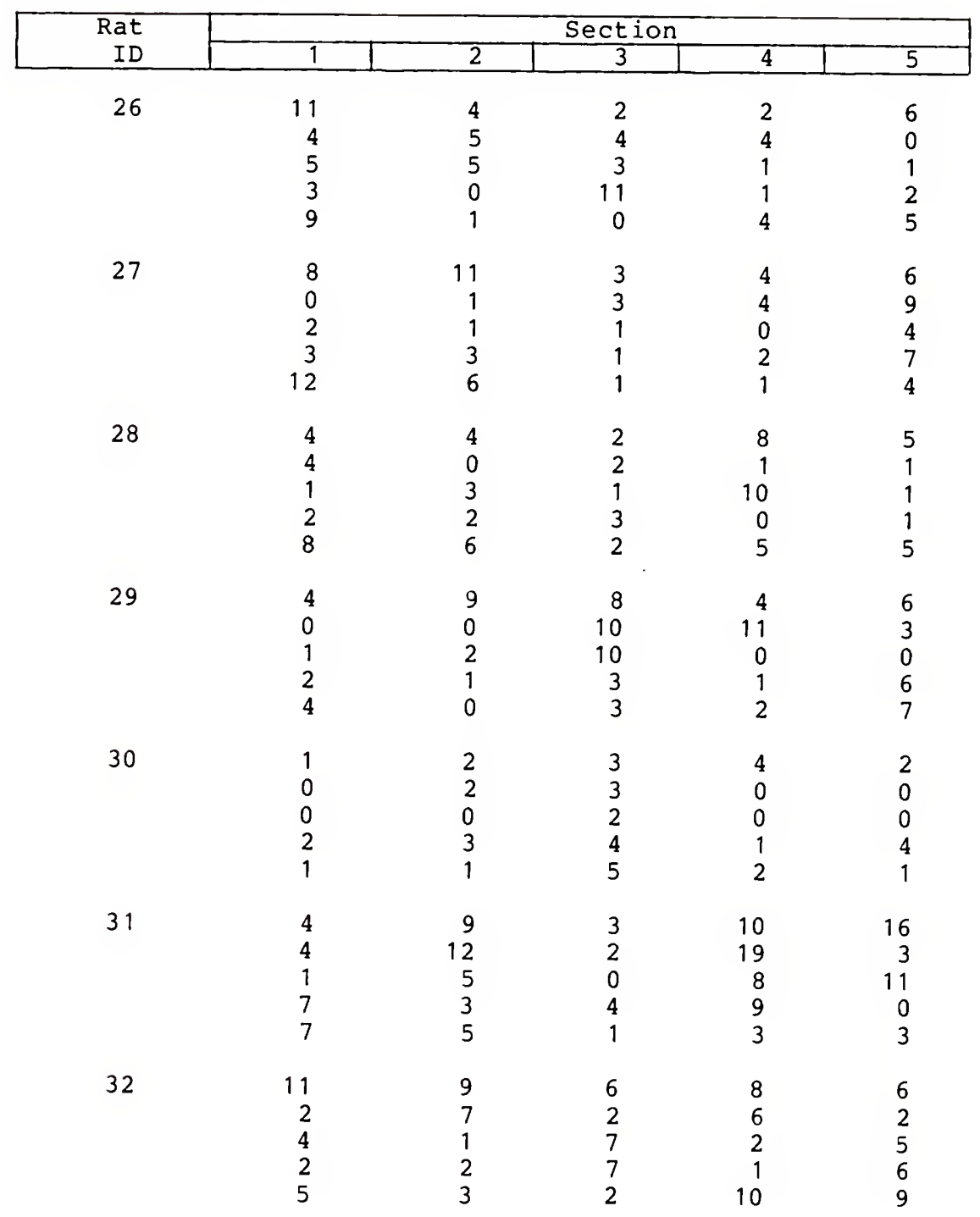


TABLE I. 2

MAST CELL COUNT--VAGINAL TISSUE

-CA DIET

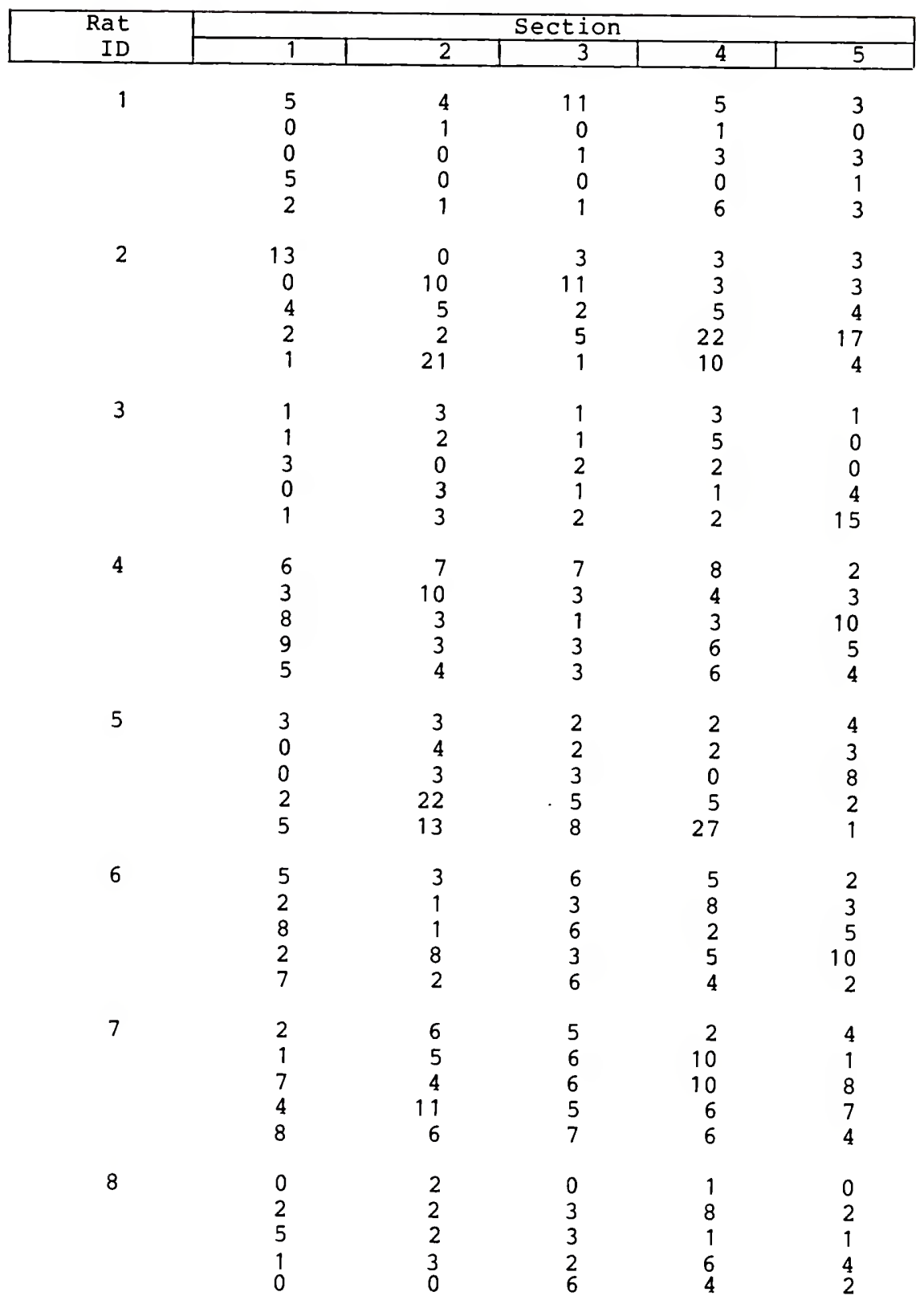


Table I. 2 continued

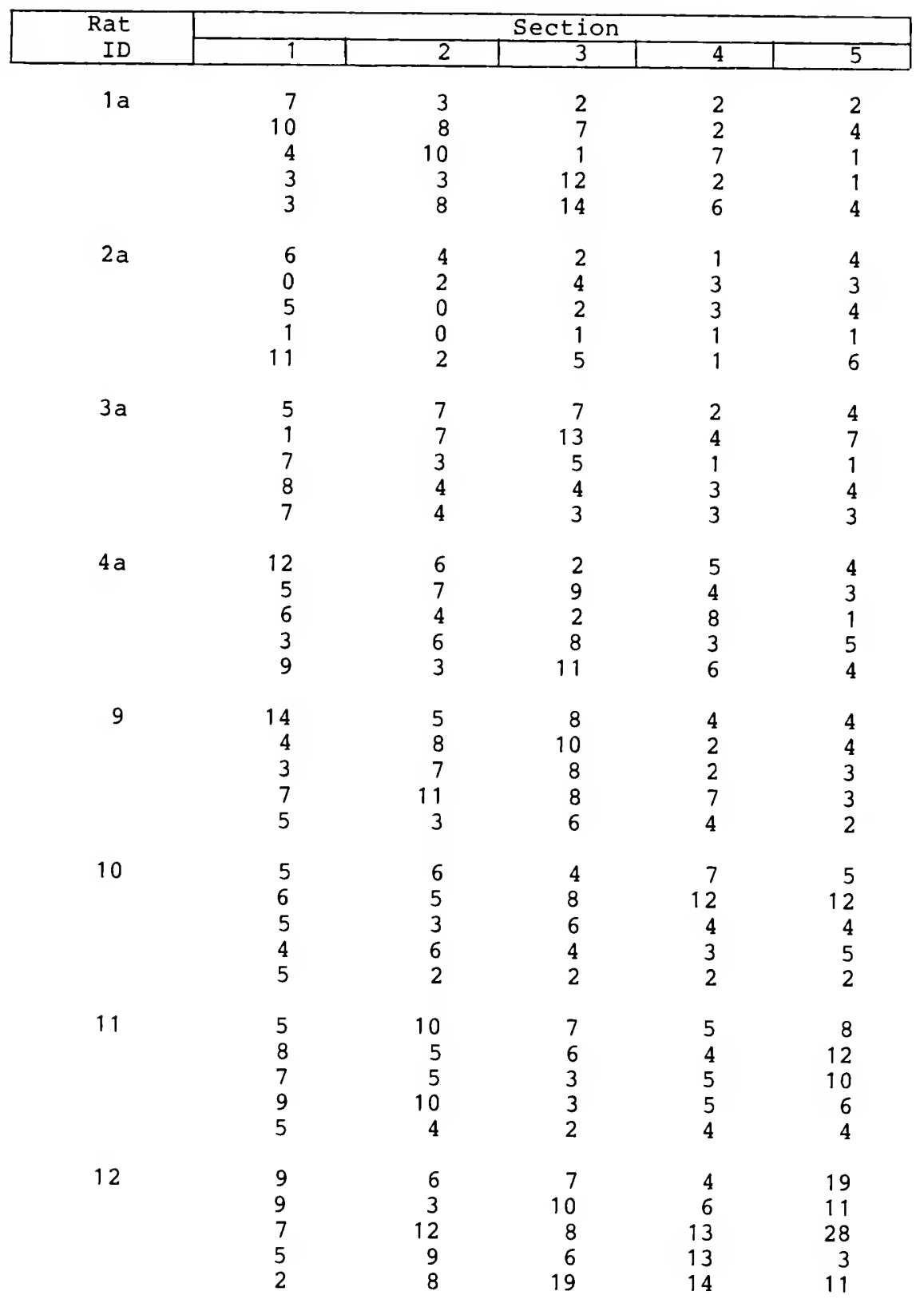


Table I. 2 continued

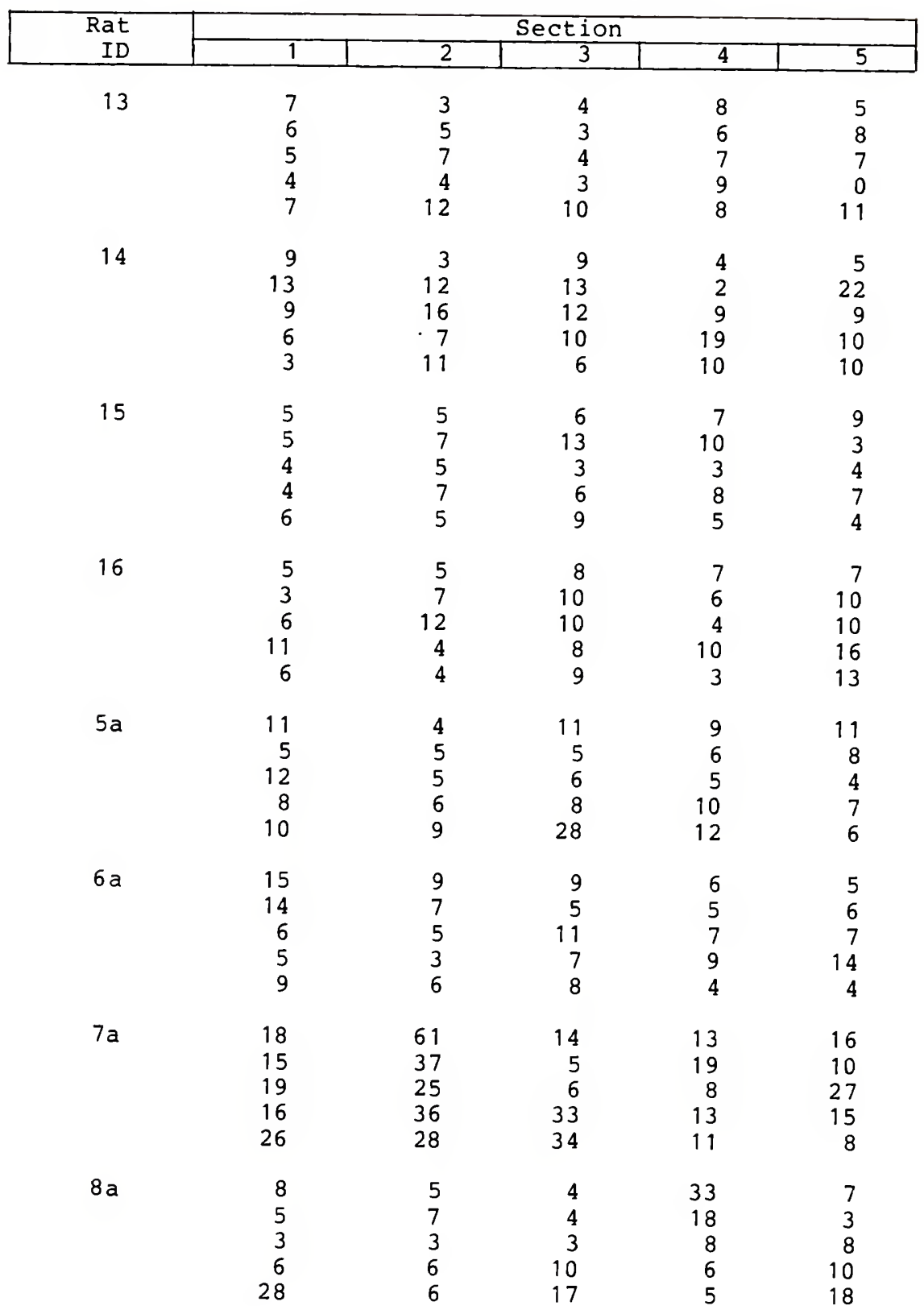


Table I. 2 continued

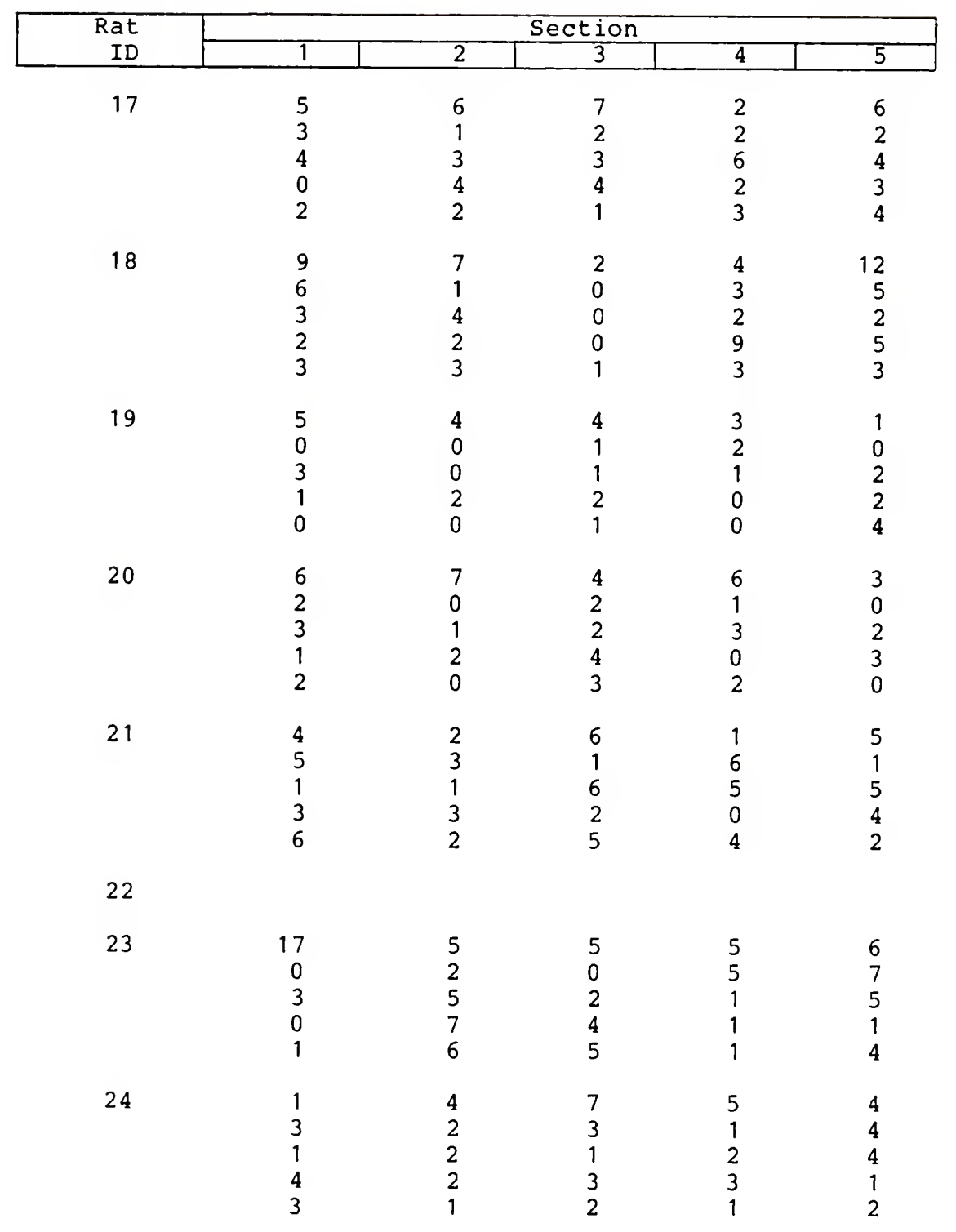


Table I. 2 continued

\begin{tabular}{|c|c|c|c|c|c|}
\hline \multirow{2}{*}{$\begin{array}{r}\text { Rat } \\
\text { ID }\end{array}$} & \multicolumn{5}{|c|}{ Section } \\
\hline & 1 & 2 & 3 & 4 & 5 \\
\hline \multirow[t]{5}{*}{25} & 5 & 6 & 1 & 3 & 1 \\
\hline & 1 & 0 & 7 & 6 & 3 \\
\hline & 2 & 2 & 0 & 3 & 4 \\
\hline & 1 & 6 & 4 & 0 & 1 \\
\hline & 1 & 3 & 3 & 2 & 2 \\
\hline \multirow[t]{5}{*}{26} & 5 & 4 & 6 & 6 & 6 \\
\hline & 4 & 2 & 2 & 2 & 2 \\
\hline & 2 & 1 & 1 & 6 & 3 \\
\hline & 0 & 0 & 5 & 5 & 2 \\
\hline & 3 & 1 & 0 & 0 & 4 \\
\hline \multicolumn{6}{|l|}{27} \\
\hline \multirow[t]{5}{*}{28} & 4 & 14 & 17 & 4 & 5 \\
\hline & 4 & 0 & 0 & 1 & 3 \\
\hline & 3 & 8 & 5 & 2 & 3 \\
\hline & 3 & 2 & 0 & 6 & 2 \\
\hline & 6 & 3 & 2 & 4 & 5 \\
\hline \multirow[t]{5}{*}{29} & 7 & 3 & 5 & 6 & 3 \\
\hline & 4 & 5 & 4 & 1 & 4 \\
\hline & 7 & 7 & 0 & 1 & 2 \\
\hline & 5 & 3 & 5 & 5 & 6 \\
\hline & 3 & 5 & 2 & 3 & 6 \\
\hline \multirow[t]{5}{*}{30} & 5 & 5 & 2 & 1 & 8 \\
\hline & 0 & 1 & 2 & 1 & 1 \\
\hline & 0 & 1 & 0 & 0 & 8 \\
\hline & 1 & 2 & 4 & 0 & 2 \\
\hline & 1 & 1 & 1 & 0 & 1 \\
\hline \multirow[t]{5}{*}{31} & 5 & 4 & 7 & 2 & 8 \\
\hline & 5 & 3 & 3 & 2 & 1 \\
\hline & 1 & 5 & 3 & 1 & 0 \\
\hline & 0 & 1 & 12 & 0 & 2 \\
\hline & 2 & 0 & 5 & 2 & 1 \\
\hline \multirow[t]{5}{*}{32} & 6 & 2 & 3 & 9 & 5 \\
\hline & 1 & 0 & 0 & 1 & 5 \\
\hline & 1 & 4 & 3 & 0 & 4 \\
\hline & 6 & 2 & 5 & 2 & 5 \\
\hline & 3 & 2 & 2 & 0 & 2 \\
\hline
\end{tabular}


TABLE I. 3

MAST CELL COUNT--VAGINAL TISSUE

$-D$ DIET

\begin{tabular}{|c|c|c|c|c|c|}
\hline \multirow{2}{*}{$\begin{array}{r}\text { Rat } \\
\text { ID } \\
\end{array}$} & \multicolumn{5}{|c|}{ section } \\
\hline & 1 & 2 & 3 & 4 & 5 \\
\hline 1 & $\begin{array}{r}10 \\
5 \\
10 \\
14 \\
7\end{array}$ & $\begin{array}{r}4 \\
14 \\
5 \\
6 \\
6\end{array}$ & $\begin{array}{l}6 \\
7 \\
6 \\
7 \\
7\end{array}$ & $\begin{array}{l}5 \\
4 \\
7 \\
4 \\
8\end{array}$ & $\begin{array}{l}6 \\
4 \\
6 \\
4 \\
3\end{array}$ \\
\hline 2 & $\begin{array}{r}8 \\
17 \\
17 \\
21 \\
16\end{array}$ & $\begin{array}{l}6 \\
4 \\
5 \\
6 \\
4\end{array}$ & $\begin{array}{r}19 \\
4 \\
4 \\
33 \\
32\end{array}$ & $\begin{array}{r}6 \\
21 \\
12 \\
4 \\
20\end{array}$ & $\begin{array}{r}16 \\
13 \\
35 \\
4 \\
5\end{array}$ \\
\hline 3 & $\begin{array}{l}3 \\
3 \\
3 \\
4 \\
5\end{array}$ & $\begin{array}{l}5 \\
8 \\
2 \\
5 \\
6\end{array}$ & $\begin{array}{l}5 \\
5 \\
3 \\
2 \\
4\end{array}$ & $\begin{array}{l}6 \\
6 \\
6 \\
4 \\
0\end{array}$ & $\begin{array}{l}4 \\
5 \\
3 \\
6 \\
8\end{array}$ \\
\hline 4 & $\begin{array}{l}8 \\
5 \\
4 \\
6 \\
4\end{array}$ & $\begin{array}{r}5 \\
10 \\
6 \\
3 \\
4\end{array}$ & $\begin{array}{r}3 \\
2 \\
13 \\
2 \\
1\end{array}$ & $\begin{array}{l}3 \\
3 \\
4 \\
8 \\
7\end{array}$ & $\begin{array}{r}9 \\
10 \\
3 \\
5 \\
5\end{array}$ \\
\hline 5 & $\begin{array}{r}5 \\
10 \\
8 \\
5 \\
9\end{array}$ & $\begin{array}{r}6 \\
11 \\
9 \\
4 \\
6\end{array}$ & $\begin{array}{r}13 \\
7 \\
5 \\
13 \\
3\end{array}$ & $\begin{array}{r}24 \\
9 \\
4 \\
2 \\
13\end{array}$ & $\begin{array}{r}16 \\
9 \\
5 \\
7 \\
3\end{array}$ \\
\hline 6 & $\begin{array}{l}6 \\
6 \\
6 \\
8 \\
6\end{array}$ & $\begin{array}{r}7 \\
11 \\
6 \\
15 \\
13\end{array}$ & $\begin{array}{r}11 \\
10 \\
15 \\
1 \\
1\end{array}$ & $\begin{array}{r}12 \\
10 \\
5 \\
5 \\
5\end{array}$ & $\begin{array}{r}10 \\
5 \\
2 \\
26 \\
2\end{array}$ \\
\hline 7 & $\begin{array}{l}4 \\
6 \\
2 \\
2 \\
3\end{array}$ & $\begin{array}{l}9 \\
2 \\
4 \\
6 \\
7\end{array}$ & $\begin{array}{r}7 \\
10 \\
5 \\
4 \\
4\end{array}$ & $\begin{array}{r}5 \\
2 \\
5 \\
11 \\
5\end{array}$ & $\begin{array}{l}6 \\
5 \\
7 \\
3 \\
2\end{array}$ \\
\hline 8 & $\begin{array}{r}7 \\
13 \\
6 \\
5 \\
6\end{array}$ & $\begin{array}{l}8 \\
2 \\
6 \\
6 \\
2\end{array}$ & $\begin{array}{l}7 \\
3 \\
3 \\
2 \\
3\end{array}$ & $\begin{array}{l}5 \\
7 \\
3 \\
5 \\
4\end{array}$ & $\begin{array}{l}4 \\
5 \\
5 \\
2 \\
4\end{array}$ \\
\hline
\end{tabular}


Table I. 3 continued

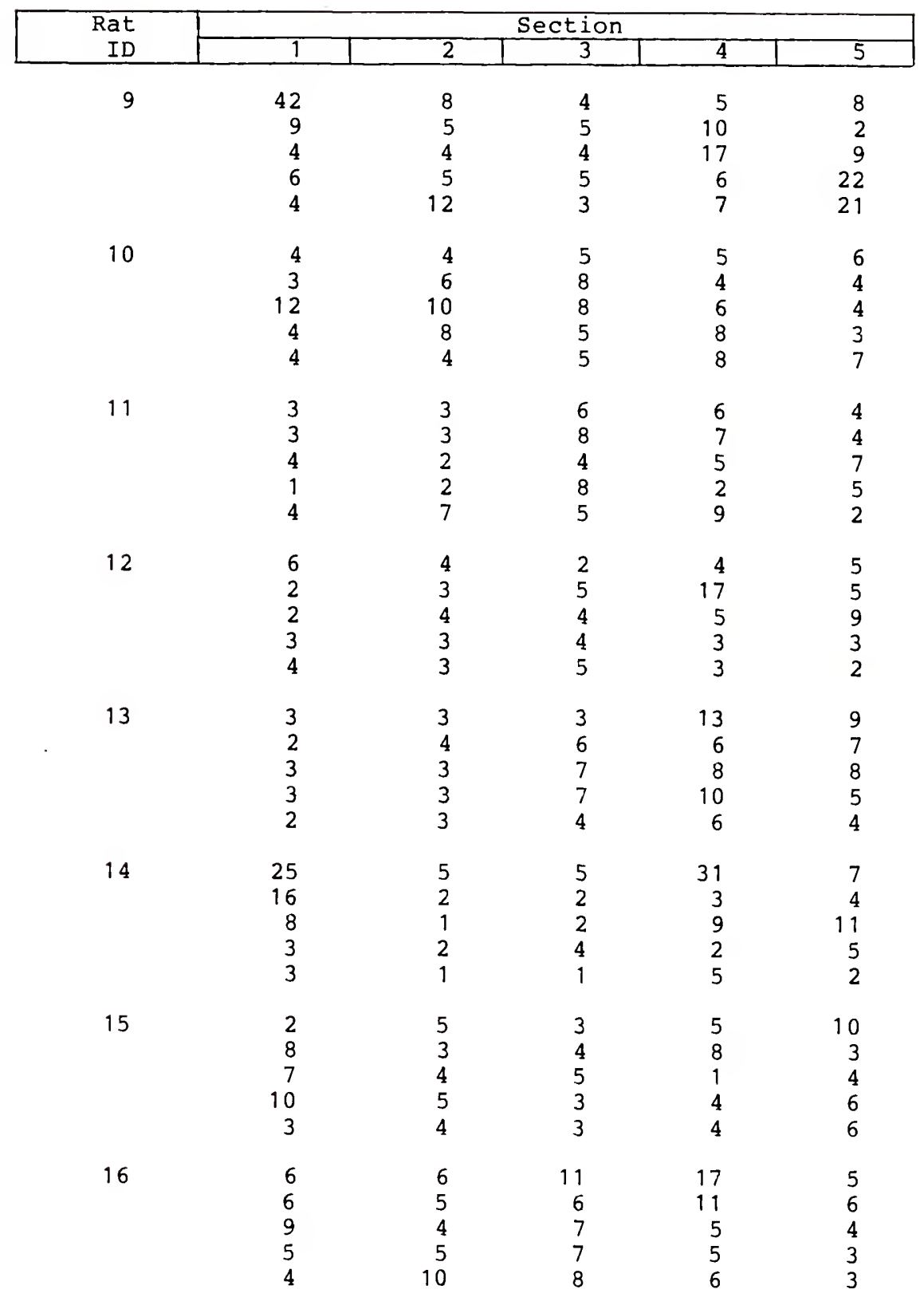


Table I.3 continued

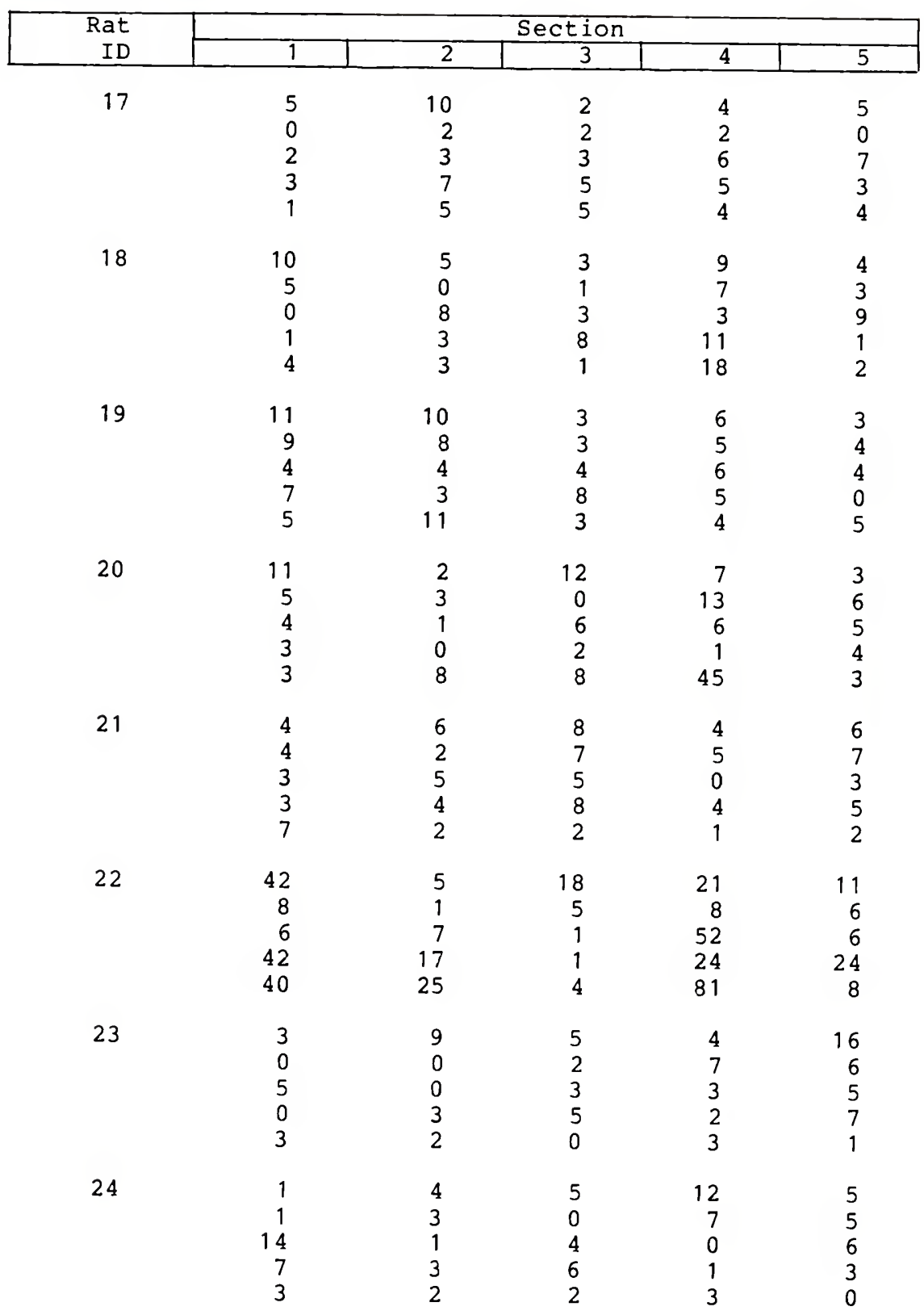


Table I. 3 continued

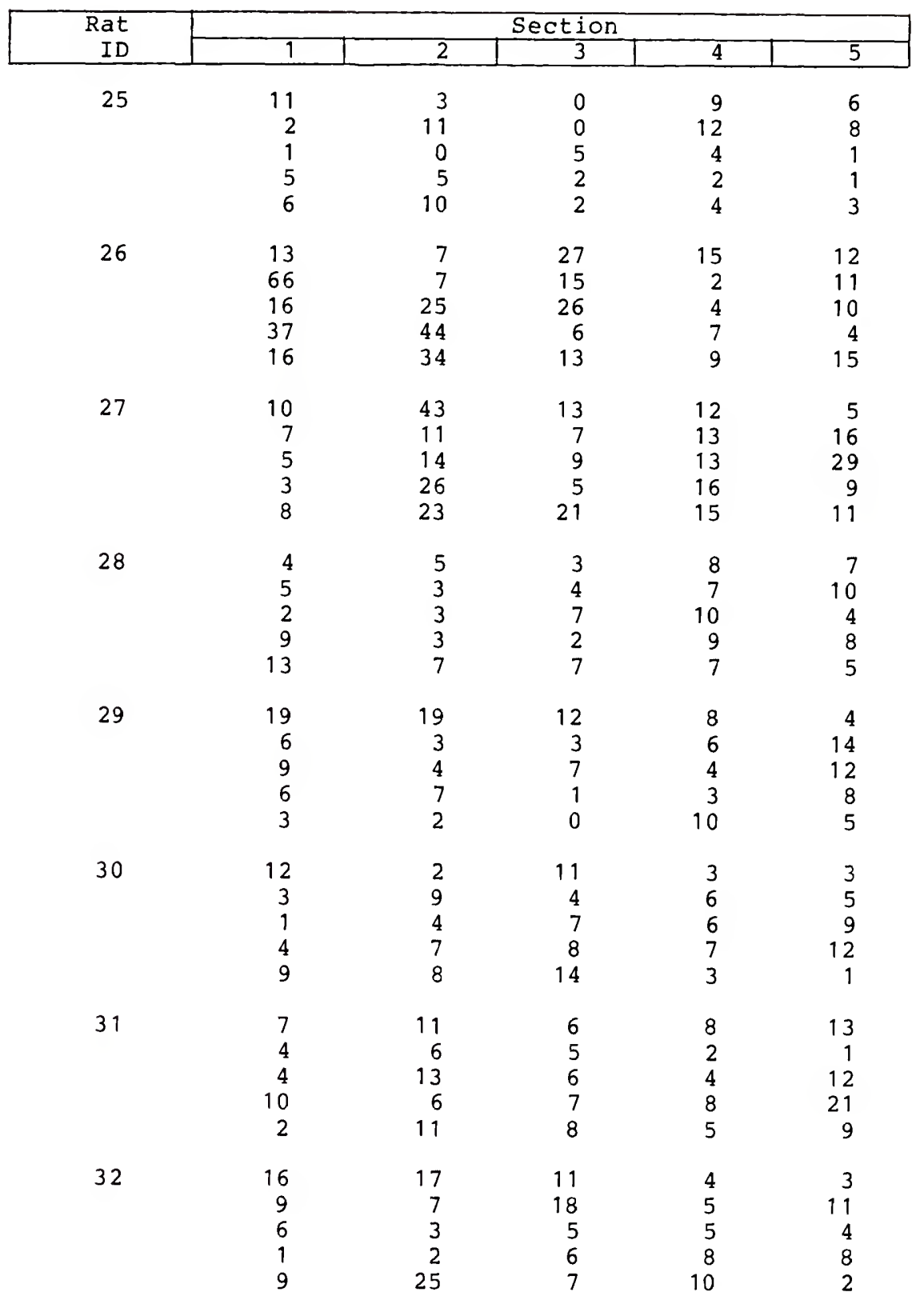


TABLE I. 4

MAST CELL COUNT--VAGINAL TISSUE

-CA, -D DIET

\begin{tabular}{|c|c|c|c|c|c|}
\hline \multirow{2}{*}{$\begin{array}{r}\text { Rat } \\
\text { ID }\end{array}$} & \multicolumn{5}{|c|}{ Section } \\
\hline & 1 & 2 & 3 & 4 & 5 \\
\hline 1 & $\begin{array}{r}1 \\
4 \\
7 \\
2 \\
10\end{array}$ & $\begin{array}{r}5 \\
6 \\
4 \\
2 \\
10\end{array}$ & $\begin{array}{l}3 \\
4 \\
8 \\
3 \\
2\end{array}$ & $\begin{array}{l}5 \\
6 \\
3 \\
5 \\
4\end{array}$ & $\begin{array}{l}8 \\
7 \\
4 \\
7 \\
6\end{array}$ \\
\hline 2 & $\begin{array}{r}4 \\
6 \\
10 \\
9 \\
5\end{array}$ & $\begin{array}{r}6 \\
4 \\
11 \\
3 \\
5\end{array}$ & $\begin{array}{r}7 \\
8 \\
7 \\
6 \\
10\end{array}$ & $\begin{array}{r}12 \\
5 \\
7 \\
4 \\
3\end{array}$ & $\begin{array}{l}5 \\
4 \\
2 \\
3 \\
3\end{array}$ \\
\hline 3 & $\begin{array}{l}4 \\
7 \\
6 \\
5 \\
7\end{array}$ & $\begin{array}{l}5 \\
3 \\
5 \\
5 \\
7\end{array}$ & $\begin{array}{r}2 \\
10 \\
6 \\
10 \\
5\end{array}$ & $\begin{array}{l}6 \\
3 \\
2 \\
3 \\
2\end{array}$ & $\begin{array}{l}6 \\
4 \\
7 \\
6 \\
8\end{array}$ \\
\hline 4 & $\begin{array}{l}3 \\
6 \\
2 \\
4 \\
5\end{array}$ & $\begin{array}{l}2 \\
4 \\
5 \\
6 \\
2\end{array}$ & $\begin{array}{l}4 \\
1 \\
5 \\
5 \\
3\end{array}$ & $\begin{array}{r}7 \\
7 \\
4 \\
3 \\
10\end{array}$ & $\begin{array}{l}6 \\
3 \\
3 \\
2 \\
5\end{array}$ \\
\hline 5 & $\begin{array}{r}4 \\
11 \\
7 \\
23 \\
12\end{array}$ & $\begin{array}{l}5 \\
4 \\
6 \\
6 \\
3\end{array}$ & $\begin{array}{r}6 \\
7 \\
3 \\
18 \\
4\end{array}$ & $\begin{array}{r}11 \\
9 \\
10 \\
5 \\
7\end{array}$ & $\begin{array}{r}6 \\
5 \\
12 \\
2 \\
12\end{array}$ \\
\hline 6 & $\begin{array}{r}3 \\
5 \\
13 \\
11 \\
8\end{array}$ & $\begin{array}{r}9 \\
3 \\
2 \\
9 \\
13\end{array}$ & $\begin{array}{r}7 \\
2 \\
8 \\
3 \\
12\end{array}$ & $\begin{array}{r}2 \\
17 \\
6 \\
4 \\
16\end{array}$ & $\begin{array}{r}2 \\
16 \\
12 \\
6 \\
6\end{array}$ \\
\hline 7 & $\begin{array}{r}8 \\
6 \\
12 \\
5 \\
5\end{array}$ & $\begin{array}{l}3 \\
3 \\
1 \\
1 \\
7\end{array}$ & $\begin{array}{l}5 \\
7 \\
7 \\
4 \\
5\end{array}$ & $\begin{array}{r}9 \\
2 \\
20 \\
6 \\
7\end{array}$ & $\begin{array}{r}6 \\
3 \\
3 \\
15 \\
4\end{array}$ \\
\hline 8 & $\begin{array}{r}9 \\
3 \\
6 \\
10 \\
3\end{array}$ & $\begin{array}{r}7 \\
11 \\
8 \\
12 \\
5\end{array}$ & $\begin{array}{l}5 \\
3 \\
3 \\
8 \\
4\end{array}$ & $\begin{array}{r}4 \\
3 \\
38 \\
28 \\
5\end{array}$ & $\begin{array}{l}7 \\
7 \\
6 \\
8 \\
5\end{array}$ \\
\hline
\end{tabular}


Table I. 4 continued

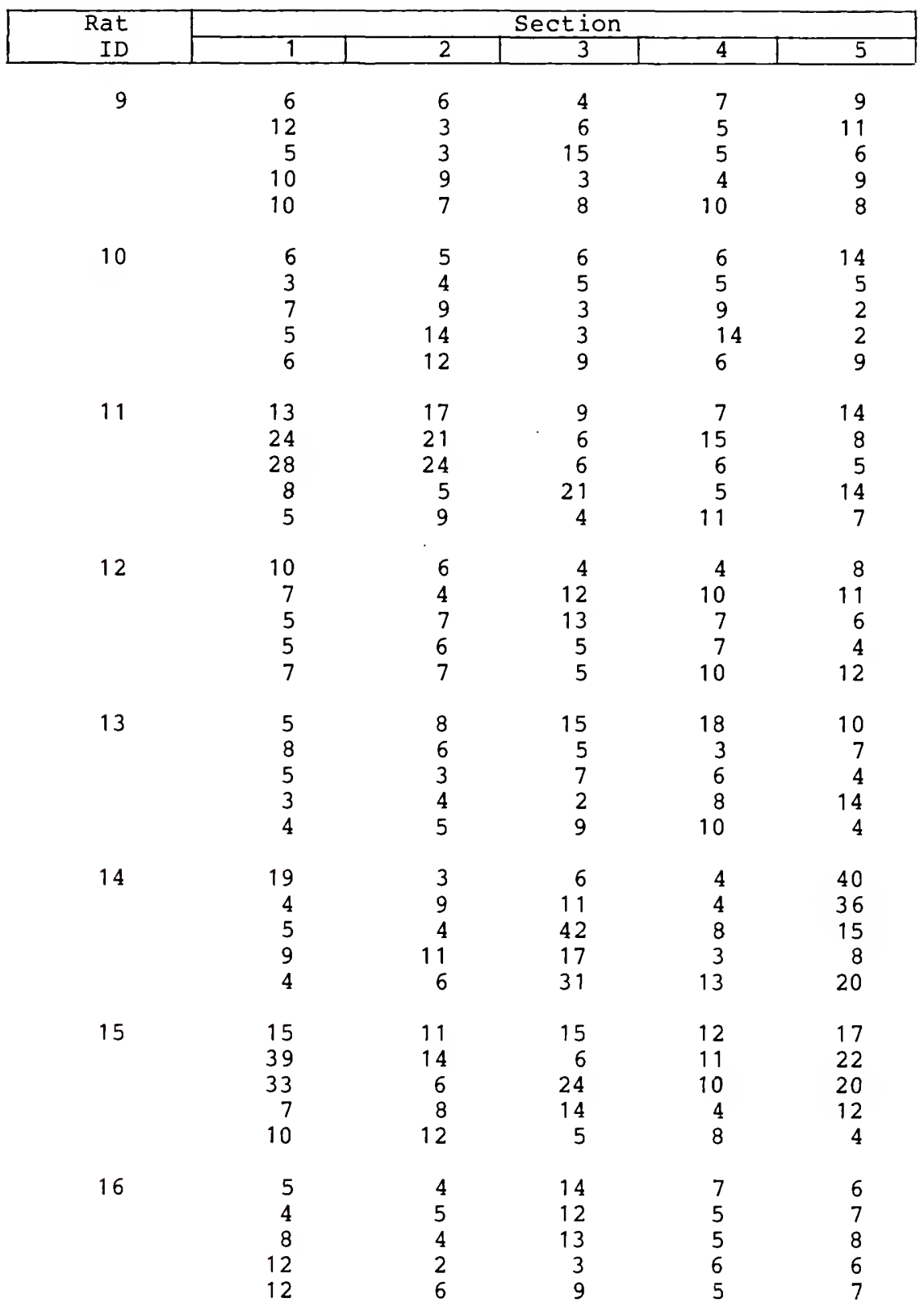


Table I. 4 continued

\begin{tabular}{|c|c|c|c|c|c|}
\hline \multirow{2}{*}{$\begin{array}{r}\text { Rat } \\
\text { ID } \\
\end{array}$} & \multicolumn{5}{|c|}{ Section } \\
\hline & 1 & 2 & 3 & 4 & 5 \\
\hline \multirow[t]{5}{*}{17} & 7 & 5 & 6 & 3 & 4 \\
\hline & 7 & 4 & 5 & 3 & 0 \\
\hline & 5 & 6 & 4 & 2 & 1 \\
\hline & 8 & 4 & 8 & 0 & 4 \\
\hline & 5 & 5 & 6 & 9 & 1 \\
\hline \multirow[t]{5}{*}{18} & 4 & 3 & 11 & 4 & 7 \\
\hline & 16 & 4 & 15 & 6 & 3 \\
\hline & 11 & 14 & 8 & 11 & 0 \\
\hline & 8 & 16 & 8 & 10 & 13 \\
\hline & 8 & 4 & 4 & 2 & 4 \\
\hline \multirow[t]{5}{*}{19} & 2 & 4 & 5 & 4 & 1 \\
\hline & 6 & 3 & 1 & 0 & 3 \\
\hline & 2 & 1 & 4 & 0 & 2 \\
\hline & 7 & 2 & 4 & 0 & 2 \\
\hline & 2 & 3 & 2 & 5 & 2 \\
\hline \multirow[t]{5}{*}{20} & 4 & 5 & 12 & 1 & 2 \\
\hline & 1 & 1 & 2 & 4 & 3 \\
\hline & 2 & 3 & 9 & 0 & 7 \\
\hline & 1 & 2 & 4 & 6 & 1 \\
\hline & 3 & 5 & 2 & 0 & 1 \\
\hline \multirow[t]{5}{*}{21} & 12 & 7 & 26 & 13 & 6 \\
\hline & 2 & 0 & 21 & 0 & 1 \\
\hline & 3 & 1 & 2 & 0 & 2 \\
\hline & 1 & 0 & 0 & 1 & 2 \\
\hline & 0 & 4 & 3 & 3 & 2 \\
\hline \multirow[t]{5}{*}{22} & 2 & 6 & 1 & 4 & 1 \\
\hline & 2 & 0 & 1 & 3 & 5 \\
\hline & 1 & 2 & 2 & 4 & 1 \\
\hline & 6 & 1 & 4 & 5 & 0 \\
\hline & 2 & 2 & 6 & 2 & 2 \\
\hline \multirow[t]{5}{*}{23} & 5 & 3 & 4 & 5 & 3 \\
\hline & 4 & 2 & 2 & 0 & 0 \\
\hline & 1 & 1 & 6 & 0 & 3 \\
\hline & 5 & 2 & 2 & 1 & 3 \\
\hline & 1 & 0 & 1 & 1 & 3 \\
\hline \multirow[t]{5}{*}{24} & 4 & 7 & 12 & 14 & 9 \\
\hline & 2 & 5 & 4 & 11 & 8 \\
\hline & 1 & 0 & 5 & 3 & 6 \\
\hline & 8 & 7 & 8 & 11 & 8 \\
\hline & 3 & 2 & 2 & 7 & 5 \\
\hline
\end{tabular}


Table I. 4 continued

\begin{tabular}{|c|c|c|c|c|c|}
\hline \multirow{2}{*}{$\begin{array}{r}\text { Rat } \\
\text { ID }\end{array}$} & \multicolumn{5}{|c|}{ Section } \\
\hline & 1 & 2 & 3 & 4 & 5 \\
\hline 25 & $\begin{array}{l}4 \\
4 \\
2 \\
1 \\
6\end{array}$ & $\begin{array}{r}7 \\
12 \\
3 \\
5 \\
4\end{array}$ & $\begin{array}{r}10 \\
6 \\
0 \\
2 \\
3\end{array}$ & $\begin{array}{r}11 \\
6 \\
4 \\
5 \\
7\end{array}$ & $\begin{array}{l}7 \\
5 \\
5 \\
4 \\
5\end{array}$ \\
\hline 26 & & & & & \\
\hline 27 & $\begin{array}{l}3 \\
5 \\
7 \\
0 \\
2\end{array}$ & $\begin{array}{r}13 \\
8 \\
2 \\
10 \\
5\end{array}$ & $\begin{array}{l}6 \\
5 \\
9 \\
1 \\
0\end{array}$ & $\begin{array}{l}6 \\
4 \\
4 \\
5 \\
3\end{array}$ & $\begin{array}{l}3 \\
4 \\
1 \\
2 \\
3\end{array}$ \\
\hline 28 & $\begin{array}{l}3 \\
3 \\
2 \\
1 \\
1\end{array}$ & $\begin{array}{l}9 \\
5 \\
2 \\
4 \\
8\end{array}$ & $\begin{array}{l}4 \\
3 \\
2 \\
7 \\
3\end{array}$ & $\begin{array}{r}11 \\
1 \\
2 \\
1 \\
1\end{array}$ & $\begin{array}{l}2 \\
9 \\
4 \\
8 \\
7\end{array}$ \\
\hline 29 & $\begin{array}{r}27 \\
5 \\
2 \\
2 \\
1\end{array}$ & $\begin{array}{l}4 \\
1 \\
1 \\
1 \\
2\end{array}$ & $\begin{array}{l}4 \\
2 \\
3 \\
0 \\
2\end{array}$ & $\begin{array}{l}7 \\
1 \\
2 \\
0 \\
4\end{array}$ & $\begin{array}{l}0 \\
0 \\
0 \\
1 \\
1\end{array}$ \\
\hline 30 & $\begin{array}{r}12 \\
8 \\
3 \\
17 \\
16\end{array}$ & $\begin{array}{l}6 \\
8 \\
7 \\
4 \\
7\end{array}$ & $\begin{array}{l}9 \\
9 \\
4 \\
9 \\
2\end{array}$ & $\begin{array}{r}11 \\
3 \\
5 \\
7 \\
0\end{array}$ & $\begin{array}{l}8 \\
5 \\
5 \\
2 \\
4\end{array}$ \\
\hline 31 & $\begin{array}{l}1 \\
4 \\
0 \\
3 \\
5\end{array}$ & $\begin{array}{l}5 \\
1 \\
1 \\
4 \\
1\end{array}$ & $\begin{array}{l}3 \\
1 \\
1 \\
9 \\
4\end{array}$ & $\begin{array}{l}3 \\
2 \\
4 \\
3 \\
4\end{array}$ & $\begin{array}{l}5 \\
3 \\
7 \\
1 \\
2\end{array}$ \\
\hline 32 & $\begin{array}{l}4 \\
7 \\
5 \\
6 \\
9\end{array}$ & $\begin{array}{r}6 \\
7 \\
8 \\
13 \\
4\end{array}$ & $\begin{array}{r}11 \\
8 \\
3 \\
1 \\
2\end{array}$ & $\begin{array}{r}15 \\
6 \\
2 \\
5 \\
4\end{array}$ & $\begin{array}{l}4 \\
5 \\
3 \\
5 \\
1\end{array}$ \\
\hline
\end{tabular}


TABLE I. 5

MAST CELL COUNT--BONE MARROW

NORMAL DIET

\begin{tabular}{|c|c|c|c|c|c|}
\hline \multirow{2}{*}{$\begin{array}{r}\text { Rat } \\
\text { ID } \\
\end{array}$} & \multicolumn{5}{|c|}{ Section } \\
\hline & 1 & 2 & 3 & 4 & 5 \\
\hline 1 & $\begin{array}{r}24 \\
29 \\
3 \\
6 \\
0\end{array}$ & $\begin{array}{r}1 \\
0 \\
0 \\
0 \\
33\end{array}$ & $\begin{array}{l}1 \\
1 \\
0 \\
0 \\
0\end{array}$ & $\begin{array}{l}6 \\
1 \\
0 \\
0 \\
0\end{array}$ & $\begin{array}{l}0 \\
0 \\
0 \\
1 \\
0\end{array}$ \\
\hline 2 & $\begin{array}{l}0 \\
0 \\
0 \\
0 \\
0\end{array}$ & $\begin{array}{l}0 \\
0 \\
0 \\
0 \\
0\end{array}$ & $\begin{array}{l}0 \\
0 \\
0 \\
0 \\
0\end{array}$ & $\begin{array}{l}0 \\
0 \\
0 \\
0 \\
0\end{array}$ & $\begin{array}{l}0 \\
0 \\
0 \\
0 \\
0\end{array}$ \\
\hline 3 & $\begin{array}{r}21 \\
7 \\
11 \\
17 \\
31\end{array}$ & $\begin{array}{r}22 \\
5 \\
32 \\
14 \\
19\end{array}$ & $\begin{array}{l}22 \\
10 \\
17 \\
40 \\
16\end{array}$ & $\begin{array}{l}35 \\
42 \\
57 \\
49 \\
52\end{array}$ & $\begin{array}{r}92 \\
62 \\
103 \\
38 \\
25\end{array}$ \\
\hline 4 & $\begin{array}{l}0 \\
0 \\
0 \\
0 \\
0\end{array}$ & $\begin{array}{l}0 \\
0 \\
0 \\
2 \\
0\end{array}$ & $\begin{array}{l}0 \\
0 \\
0 \\
0 \\
4\end{array}$ & $\begin{array}{l}3 \\
0 \\
4 \\
0 \\
0\end{array}$ & $\begin{array}{l}2 \\
5 \\
4 \\
0 \\
0\end{array}$ \\
\hline 5 & $\begin{array}{l}36 \\
39 \\
42 \\
28 \\
39\end{array}$ & $\begin{array}{l}31 \\
27 \\
22 \\
20 \\
23\end{array}$ & $\begin{array}{r}23 \\
24 \\
22 \\
6 \\
0\end{array}$ & $\begin{array}{l}26 \\
31 \\
32 \\
31 \\
34\end{array}$ & $\begin{array}{l}34 \\
32 \\
17 \\
34 \\
15\end{array}$ \\
\hline 6 & $\begin{array}{r}10 \\
39 \\
6 \\
8 \\
0\end{array}$ & $\begin{array}{r}3 \\
8 \\
12 \\
7 \\
19\end{array}$ & $\begin{array}{r}0 \\
2 \\
0 \\
18 \\
46\end{array}$ & $\begin{array}{l}32 \\
10 \\
21 \\
28 \\
38\end{array}$ & $\begin{array}{r}36 \\
11 \\
2 \\
18 \\
17\end{array}$ \\
\hline 7 & $\begin{array}{r}0 \\
0 \\
0 \\
0 \\
26\end{array}$ & $\begin{array}{r}5 \\
8 \\
11 \\
12 \\
5\end{array}$ & $\begin{array}{r}15 \\
2 \\
21 \\
14 \\
17\end{array}$ & $\begin{array}{r}15 \\
9 \\
8 \\
12 \\
0\end{array}$ & $\begin{array}{r}4 \\
5 \\
5 \\
5 \\
12\end{array}$ \\
\hline 8 & $\begin{array}{r}109 \\
64 \\
56 \\
78\end{array}$ & $\begin{array}{l}27 \\
58 \\
33 \\
18\end{array}$ & $\begin{array}{r}49 \\
29 \\
9 \\
11\end{array}$ & $\begin{array}{r}82 \\
101 \\
107 \\
92\end{array}$ & $\begin{array}{l}33 \\
13 \\
16 \\
15\end{array}$ \\
\hline & 73 & 21 & 32 & 47 & 7 \\
\hline
\end{tabular}


Table I. 5 continued

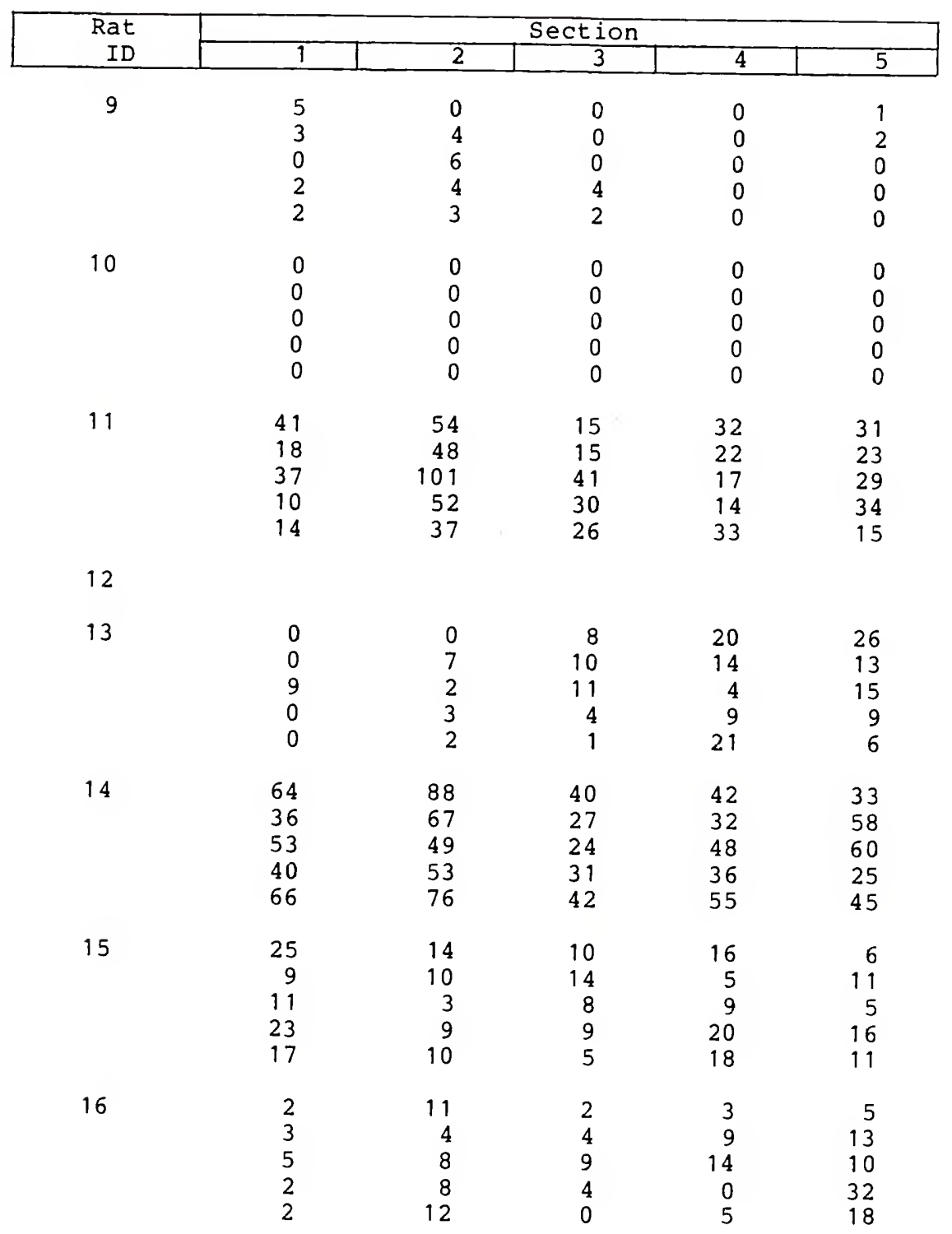


Table I.5 continued

\begin{tabular}{|c|c|c|c|c|c|}
\hline \multirow{2}{*}{$\begin{array}{r}\text { Rat } \\
\text { ID }\end{array}$} & \multicolumn{5}{|c|}{ Section } \\
\hline & 1 & 2 & 3 & 4 & 5 \\
\hline 17 & $\begin{array}{r}48 \\
41 \\
57 \\
84 \\
102\end{array}$ & $\begin{array}{l}75 \\
80 \\
65 \\
56 \\
66\end{array}$ & $\begin{array}{l}26 \\
16 \\
26 \\
24 \\
37\end{array}$ & $\begin{array}{l}27 \\
33 \\
26 \\
20 \\
29\end{array}$ & $\begin{array}{l}91 \\
62 \\
75 \\
83 \\
28\end{array}$ \\
\hline 18 & $\begin{array}{l}32 \\
21 \\
35 \\
21 \\
15\end{array}$ & $\begin{array}{l}31 \\
21 \\
23 \\
27 \\
27\end{array}$ & $\begin{array}{l}20 \\
21 \\
13 \\
19 \\
34\end{array}$ & $\begin{array}{l}33 \\
32 \\
25 \\
26 \\
34\end{array}$ & $\begin{array}{l}68 \\
24 \\
63 \\
70 \\
57\end{array}$ \\
\hline 19 & $\begin{array}{l}32 \\
55 \\
68 \\
47 \\
93\end{array}$ & $\begin{array}{r}53 \\
111 \\
101 \\
54 \\
47\end{array}$ & $\begin{array}{r}52 \\
83 \\
70 \\
100 \\
96\end{array}$ & $\begin{array}{r}104 \\
126 \\
50 \\
78 \\
142\end{array}$ & $\begin{array}{l}61 \\
85 \\
23 \\
62 \\
54\end{array}$ \\
\hline 20 & $\begin{array}{l}52 \\
62 \\
32 \\
29 \\
20\end{array}$ & $\begin{array}{l}29 \\
39 \\
56 \\
76 \\
63\end{array}$ & $\begin{array}{l}59 \\
80 \\
50 \\
20 \\
50\end{array}$ & $\begin{array}{l}43 \\
34 \\
22 \\
17 \\
39\end{array}$ & $\begin{array}{l}41 \\
38 \\
30 \\
34 \\
42\end{array}$ \\
\hline 21 & $\begin{array}{l}45 \\
60 \\
43 \\
64 \\
38\end{array}$ & $\begin{array}{l}37 \\
49 \\
33 \\
32 \\
38\end{array}$ & $\begin{array}{l}13 \\
21 \\
37 \\
20 \\
38\end{array}$ & $\begin{array}{l}52 \\
59 \\
43 \\
38 \\
37\end{array}$ & $\begin{array}{l}51 \\
66 \\
29 \\
48 \\
55\end{array}$ \\
\hline 22 & & & & & \\
\hline 23 & $\begin{array}{r}84 \\
105 \\
97 \\
91 \\
62\end{array}$ & $\begin{array}{l}117 \\
137 \\
142 \\
102 \\
120\end{array}$ & $\begin{array}{r}103 \\
90 \\
99 \\
117 \\
118\end{array}$ & $\begin{array}{r}112 \\
77 \\
71 \\
90 \\
109\end{array}$ & $\begin{array}{r}168 \\
89 \\
132 \\
90 \\
52\end{array}$ \\
\hline 24 & $\begin{array}{l}64 \\
41 \\
53 \\
36 \\
21\end{array}$ & $\begin{array}{l}31 \\
34 \\
26 \\
48 \\
52\end{array}$ & $\begin{array}{l}39 \\
41 \\
28 \\
32 \\
35\end{array}$ & $\begin{array}{l}35 \\
29 \\
47 \\
17 \\
14\end{array}$ & $\begin{array}{l}45 \\
43 \\
38 \\
39 \\
31\end{array}$ \\
\hline
\end{tabular}


Table I.5 continued

\begin{tabular}{|c|c|c|c|c|c|}
\hline \multirow{2}{*}{$\begin{array}{r}\text { Rat } \\
\text { ID }\end{array}$} & \multicolumn{5}{|c|}{ Section } \\
\hline & 1 & 2 & 3 & 4 & 5 \\
\hline 25 & $\begin{array}{l}47 \\
42 \\
36 \\
25 \\
72\end{array}$ & $\begin{array}{l}35 \\
24 \\
27 \\
33 \\
33\end{array}$ & $\begin{array}{l}25 \\
37 \\
23 \\
33 \\
19\end{array}$ & $\begin{array}{l}32 \\
39 \\
22 \\
17 \\
26\end{array}$ & $\begin{array}{l}66 \\
48 \\
58 \\
68 \\
49\end{array}$ \\
\hline 26 & $\begin{array}{l}41 \\
40 \\
63 \\
51 \\
34\end{array}$ & $\begin{array}{l}45 \\
31 \\
30 \\
15 \\
30\end{array}$ & $\begin{array}{l}52 \\
28 \\
40 \\
38 \\
58\end{array}$ & $\begin{array}{l}26 \\
29 \\
35 \\
11 \\
32\end{array}$ & $\begin{array}{l}28 \\
26 \\
24 \\
25 \\
34\end{array}$ \\
\hline 27 & $\begin{array}{l}60 \\
41 \\
25 \\
30 \\
37\end{array}$ & $\begin{array}{l}34 \\
21 \\
22 \\
12 \\
11\end{array}$ & $\begin{array}{l}18 \\
16 \\
17 \\
27 \\
15\end{array}$ & $\begin{array}{r}32 \\
8 \\
14 \\
11 \\
19\end{array}$ & $\begin{array}{l}23 \\
28 \\
21 \\
15 \\
20\end{array}$ \\
\hline 28 & $\begin{array}{l}18 \\
31 \\
60 \\
37 \\
33\end{array}$ & $\begin{array}{l}38 \\
29 \\
39 \\
39 \\
27\end{array}$ & $\begin{array}{l}40 \\
34 \\
41 \\
60 \\
49\end{array}$ & $\begin{array}{l}42 \\
34 \\
36 \\
40 \\
40\end{array}$ & $\begin{array}{l}54 \\
25 \\
21 \\
17 \\
18\end{array}$ \\
\hline 29 & $\begin{array}{r}8 \\
16 \\
23 \\
17 \\
21\end{array}$ & $\begin{array}{l}12 \\
22 \\
15 \\
10 \\
32\end{array}$ & $\begin{array}{r}9 \\
14 \\
29 \\
16 \\
22\end{array}$ & $\begin{array}{l}78 \\
46 \\
44 \\
50 \\
28\end{array}$ & $\begin{array}{l}47 \\
42 \\
40 \\
56 \\
51\end{array}$ \\
\hline 30 & $\begin{array}{l}41 \\
24 \\
18 \\
34 \\
20\end{array}$ & $\begin{array}{l}15 \\
11 \\
27 \\
19 \\
28\end{array}$ & $\begin{array}{l}18 \\
10 \\
26 \\
25 \\
43\end{array}$ & $\begin{array}{l}18 \\
31 \\
21 \\
24 \\
22\end{array}$ & $\begin{array}{l}16 \\
23 \\
19 \\
32 \\
24\end{array}$ \\
\hline 31 & $\begin{array}{l}59 \\
51 \\
42 \\
60 \\
59\end{array}$ & $\begin{array}{l}56 \\
29 \\
47 \\
72 \\
46\end{array}$ & $\begin{array}{l}78 \\
67 \\
49 \\
26 \\
57\end{array}$ & $\begin{array}{r}33 \\
120 \\
59 \\
58 \\
52\end{array}$ & $\begin{array}{l}36 \\
24 \\
72 \\
48 \\
35\end{array}$ \\
\hline 32 & $\begin{array}{l}57 \\
84 \\
25 \\
33 \\
13\end{array}$ & $\begin{array}{l}20 \\
13 \\
18 \\
23 \\
22\end{array}$ & $\begin{array}{l}23 \\
32 \\
37 \\
54 \\
59\end{array}$ & $\begin{array}{l}34 \\
21 \\
16 \\
31 \\
26\end{array}$ & $\begin{array}{l}22 \\
13 \\
36 \\
12 \\
20\end{array}$ \\
\hline
\end{tabular}


TABLE I. 6

MAST CELL COUNT--BONE MARROW

-CA DIET

\begin{tabular}{|c|c|c|c|c|c|}
\hline \multirow{2}{*}{$\begin{array}{r}\text { Rat } \\
\text { ID }\end{array}$} & \multicolumn{5}{|c|}{ Section } \\
\hline & 1 & 2 & 3 & 4 & 5 \\
\hline 1 & $\begin{array}{l}20 \\
35 \\
20 \\
20 \\
68\end{array}$ & $\begin{array}{l}2 \\
0 \\
0 \\
0 \\
0\end{array}$ & $\begin{array}{r}24 \\
9 \\
10 \\
21 \\
11\end{array}$ & $\begin{array}{l}45 \\
44 \\
42 \\
21 \\
14\end{array}$ & $\begin{array}{r}8 \\
21 \\
15 \\
52 \\
12\end{array}$ \\
\hline 2 & $\begin{array}{l}40 \\
25 \\
47 \\
32 \\
47\end{array}$ & $\begin{array}{l}44 \\
43 \\
42 \\
34 \\
48\end{array}$ & $\begin{array}{l}32 \\
48 \\
47 \\
50 \\
61\end{array}$ & $\begin{array}{l}43 \\
56 \\
53 \\
51 \\
45\end{array}$ & $\begin{array}{l}30 \\
17 \\
17 \\
21 \\
34\end{array}$ \\
\hline 3 & $\begin{array}{r}2 \\
4 \\
35 \\
29 \\
17\end{array}$ & $\begin{array}{l}29 \\
27 \\
40 \\
20 \\
27\end{array}$ & $\begin{array}{l}13 \\
18 \\
18 \\
23 \\
27\end{array}$ & $\begin{array}{l}42 \\
17 \\
17 \\
22 \\
16\end{array}$ & $\begin{array}{l}46 \\
10 \\
20 \\
22 \\
28\end{array}$ \\
\hline 4 & $\begin{array}{l}31 \\
25 \\
51 \\
23 \\
42\end{array}$ & $\begin{array}{l}41 \\
71 \\
57 \\
85 \\
56\end{array}$ & $\begin{array}{l}42 \\
44 \\
52 \\
75 \\
32\end{array}$ & $\begin{array}{l}15 \\
27 \\
35 \\
15 \\
36\end{array}$ & $\begin{array}{l}43 \\
32 \\
31 \\
35 \\
41\end{array}$ \\
\hline 5 & $\begin{array}{l}23 \\
15 \\
27 \\
26 \\
21\end{array}$ & $\begin{array}{r}22 \\
17 \\
13 \\
25 \\
9\end{array}$ & $\begin{array}{r}11 \\
21 \\
9 \\
21 \\
22\end{array}$ & $\begin{array}{l}20 \\
16 \\
33 \\
18 \\
17\end{array}$ & $\begin{array}{l}20 \\
29 \\
20 \\
14 \\
15\end{array}$ \\
\hline 6 & $\begin{array}{l}28 \\
24 \\
38 \\
45 \\
78\end{array}$ & $\begin{array}{l}96 \\
63 \\
64 \\
77 \\
33\end{array}$ & & & \\
\hline 7 & $\begin{array}{l}28 \\
27 \\
34 \\
21 \\
33\end{array}$ & $\begin{array}{l}26 \\
32 \\
27 \\
31 \\
20\end{array}$ & $\begin{array}{l}21 \\
18 \\
27 \\
14 \\
16\end{array}$ & $\begin{array}{l}24 \\
23 \\
25 \\
26 \\
26\end{array}$ & $\begin{array}{l}17 \\
44 \\
26 \\
17 \\
25\end{array}$ \\
\hline 8 & $\begin{array}{r}24 \\
12 \\
14 \\
9 \\
8\end{array}$ & $\begin{array}{r}13 \\
12 \\
9 \\
20 \\
7\end{array}$ & $\begin{array}{l}26 \\
20 \\
32 \\
33 \\
20\end{array}$ & $\begin{array}{r}29 \\
27 \\
7 \\
16 \\
8\end{array}$ & $\begin{array}{r}36 \\
21 \\
9 \\
11 \\
24\end{array}$ \\
\hline
\end{tabular}


Table I. 6 continued

\begin{tabular}{|c|c|c|c|c|c|}
\hline \multirow{2}{*}{$\begin{array}{r}\text { Rat } \\
\text { ID }\end{array}$} & \multicolumn{5}{|c|}{ Section } \\
\hline & 1 & 2 & 3 & 4 & 5 \\
\hline $1 \mathrm{a}$ & $\begin{array}{l}17 \\
21 \\
31 \\
20 \\
18\end{array}$ & $\begin{array}{l}16 \\
33 \\
41 \\
32 \\
26\end{array}$ & $\begin{array}{l}12 \\
21 \\
26 \\
32 \\
37\end{array}$ & $\begin{array}{l}24 \\
25 \\
23 \\
17 \\
25\end{array}$ & $\begin{array}{l}26 \\
12 \\
21 \\
24 \\
26\end{array}$ \\
\hline $2 a$ & $\begin{array}{l}37 \\
23 \\
31 \\
20 \\
20\end{array}$ & $\begin{array}{l}13 \\
17 \\
30 \\
30 \\
28\end{array}$ & $\begin{array}{l}33 \\
22 \\
18 \\
28 \\
22\end{array}$ & $\begin{array}{l}14 \\
17 \\
15 \\
15 \\
12\end{array}$ & $\begin{array}{l}12 \\
53 \\
19 \\
15 \\
14\end{array}$ \\
\hline $3 a$ & $\begin{array}{r}25 \\
13 \\
15 \\
11 \\
8\end{array}$ & $\begin{array}{l}8 \\
5 \\
3 \\
1 \\
1\end{array}$ & $\begin{array}{r}3 \\
4 \\
0 \\
10 \\
9\end{array}$ & $\begin{array}{l}2 \\
3 \\
1 \\
5 \\
4\end{array}$ & $\begin{array}{r}15 \\
2 \\
14 \\
1 \\
7\end{array}$ \\
\hline $4 a$ & $\begin{array}{r}16 \\
21 \\
1 \\
13 \\
19\end{array}$ & $\begin{array}{l}16 \\
14 \\
36 \\
28 \\
25\end{array}$ & $\begin{array}{r}19 \\
5 \\
17 \\
24 \\
24\end{array}$ & $\begin{array}{r}30 \\
18 \\
9 \\
19 \\
15\end{array}$ & $\begin{array}{l}30 \\
29 \\
20 \\
17 \\
20\end{array}$ \\
\hline 9 & $\begin{array}{l}36 \\
30 \\
24 \\
33 \\
17\end{array}$ & $\begin{array}{l}22 \\
23 \\
39 \\
27 \\
24\end{array}$ & $\begin{array}{l}33 \\
30 \\
53 \\
52 \\
26\end{array}$ & $\begin{array}{l}32 \\
36 \\
35 \\
27 \\
39\end{array}$ & $\begin{array}{l}30 \\
40 \\
23 \\
55 \\
47\end{array}$ \\
\hline 10 & $\begin{array}{l}29 \\
24 \\
26 \\
27 \\
17\end{array}$ & $\begin{array}{l}37 \\
11 \\
25 \\
12 \\
22\end{array}$ & $\begin{array}{l}40 \\
39 \\
41 \\
32 \\
16\end{array}$ & $\begin{array}{l}21 \\
16 \\
19 \\
13 \\
16\end{array}$ & $\begin{array}{l}15 \\
12 \\
19 \\
18 \\
18\end{array}$ \\
\hline 11 & $\begin{array}{r}10 \\
12 \\
5 \\
10 \\
5\end{array}$ & $\begin{array}{l}4 \\
6 \\
6 \\
3 \\
0\end{array}$ & $\begin{array}{r}17 \\
9 \\
9 \\
13 \\
6\end{array}$ & $\begin{array}{l}6 \\
4 \\
8 \\
9 \\
8\end{array}$ & $\begin{array}{l}8 \\
4 \\
3 \\
2 \\
2\end{array}$ \\
\hline 12 & $\begin{array}{r}18 \\
9 \\
7 \\
22 \\
22\end{array}$ & $\begin{array}{r}16 \\
17 \\
7 \\
17 \\
28\end{array}$ & $\begin{array}{l}29 \\
12 \\
19 \\
29 \\
14\end{array}$ & $\begin{array}{l}26 \\
21 \\
12 \\
27 \\
27\end{array}$ & $\begin{array}{l}10 \\
14 \\
44 \\
15 \\
31\end{array}$ \\
\hline
\end{tabular}


Table I. 6 continued

\begin{tabular}{|c|c|c|c|c|c|}
\hline \multirow{2}{*}{ Rat } & \multicolumn{5}{|c|}{ Section } \\
\cline { 2 - 6 } & 1 & 2 & 3 & 4 & 5 \\
\hline
\end{tabular}

13

14

$\begin{array}{rrrrr}49 & 26 & 18 & 27 & 37 \\ 41 & 28 & 60 & 10 & 25 \\ 25 & 64 & 30 & 6 & 13 \\ 55 & 27 & 33 & 51 & 30 \\ 21 & 22 & 20 & 28 & 16\end{array}$

15

12
1
4
3
2

33

18

20

10

28

13

1

12 . 23

5

18

16

5

17

10

16

$\begin{array}{rr}7 & 13 \\ 9 & 16 \\ 8 & 10 \\ 15 & 8 \\ 11 & 19\end{array}$

26

2

8

$\begin{array}{rr}8 & 9 \\ 9 & 12\end{array}$

24

19

$5 a$

$\begin{array}{rr}14 & 7 \\ 18 & 0 \\ 16 & 4 \\ 11 & 13 \\ 11 & 9\end{array}$

$6 a$

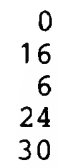

20

20

16

26

20

18

12

11

15

16

$\begin{array}{rr}0 & 16 \\ 15 & 0 \\ 12 & 5 \\ 8 & 11 \\ 16 & 6\end{array}$

$7 a$

21

20

13

27

14

13

15

18

20

18
17
12
12
20

32

24

12

48

17

16

0

11
6

15
16

17

7
5
2
0
4

21

18

21

38

15

2

46

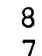

7

17

$8 a$

$\begin{array}{ll}0 & 0 \\ 0 & 0 \\ 0 & 0 \\ 0 & 0 \\ 0 & 0\end{array}$

26

42

20

34

26

$\begin{array}{ll}18 & 21 \\ 47 & 19 \\ 31 & 36 \\ 20 & 33 \\ 18 & 25\end{array}$

0

0

0

0
0

0
0
0
0
0

0
0
0
0
0

0

0

0

0 
Table I. 6 continued

\begin{tabular}{|c|c|c|c|c|c|}
\hline \multirow{2}{*}{$\begin{array}{r}\text { Rat } \\
\text { ID } \\
\end{array}$} & \multicolumn{5}{|c|}{ Section } \\
\hline & 1 & 2 & 3 & 4 & 5 \\
\hline 17 & $\begin{array}{l}52 \\
41 \\
18 \\
31 \\
29\end{array}$ & $\begin{array}{l}33 \\
34 \\
32 \\
24 \\
29\end{array}$ & $\begin{array}{l}50 \\
44 \\
50 \\
25 \\
23\end{array}$ & $\begin{array}{l}29 \\
31 \\
46 \\
41 \\
54\end{array}$ & $\begin{array}{l}21 \\
42 \\
64 \\
61 \\
31\end{array}$ \\
\hline 18 & $\begin{array}{l}60 \\
19 \\
15 \\
42 \\
48\end{array}$ & $\begin{array}{l}34 \\
52 \\
34 \\
40 \\
26\end{array}$ & $\begin{array}{l}25 \\
43 \\
21 \\
26 \\
23\end{array}$ & $\begin{array}{l}54 \\
26 \\
21 \\
18 \\
22\end{array}$ & $\begin{array}{l}37 \\
32 \\
28 \\
22 \\
28\end{array}$ \\
\hline 19 & $\begin{array}{l}46 \\
21 \\
39 \\
50 \\
27\end{array}$ & $\begin{array}{l}40 \\
32 \\
63 \\
46 \\
43\end{array}$ & $\begin{array}{l}45 \\
44 \\
33 \\
27 \\
57\end{array}$ & $\begin{array}{l}43 \\
25 \\
46 \\
27 \\
44\end{array}$ & $\begin{array}{l}23 \\
16 \\
16 \\
32 \\
28\end{array}$ \\
\hline 20 & $\begin{array}{l}27 \\
18 \\
37 \\
39 \\
24\end{array}$ & $\begin{array}{l}51 \\
54 \\
40 \\
53 \\
66\end{array}$ & $\begin{array}{l}38 \\
41 \\
51 \\
43 \\
37\end{array}$ & $\begin{array}{l}61 \\
88 \\
31 \\
36 \\
33\end{array}$ & $\begin{array}{l}49 \\
42 \\
31 \\
39 \\
36\end{array}$ \\
\hline 21 & & & & & \\
\hline 22 & $\begin{array}{l}71 \\
51 \\
32 \\
29 \\
21\end{array}$ & $\begin{array}{l}63 \\
20 \\
18 \\
19 \\
22\end{array}$ & $\begin{array}{l}17 \\
12 \\
18 \\
24 \\
36\end{array}$ & $\begin{array}{l}20 \\
61 \\
23 \\
27 \\
21\end{array}$ & $\begin{array}{l}20 \\
23 \\
21 \\
25 \\
20\end{array}$ \\
\hline 23 & $\begin{array}{l}29 \\
11 \\
16 \\
23 \\
16\end{array}$ & $\begin{array}{l}33 \\
26 \\
17 \\
22 \\
12\end{array}$ & $\begin{array}{l}22 \\
36 \\
17 \\
17 \\
23\end{array}$ & $\begin{array}{l}38 \\
21 \\
20 \\
33 \\
21\end{array}$ & $\begin{array}{l}41 \\
22 \\
19 \\
24 \\
25\end{array}$ \\
\hline 24 & $\begin{array}{r}17 \\
9 \\
7 \\
9 \\
6\end{array}$ & $\begin{array}{r}38 \\
11 \\
8 \\
12 \\
10\end{array}$ & $\begin{array}{r}21 \\
15 \\
7 \\
16 \\
15\end{array}$ & $\begin{array}{r}19 \\
12 \\
5 \\
9 \\
8\end{array}$ & $\begin{array}{l}19 \\
39 \\
61 \\
17 \\
13\end{array}$ \\
\hline
\end{tabular}


Table I. 6 continued

\begin{tabular}{|c|c|c|c|c|c|}
\hline \multirow{2}{*}{$\begin{array}{r}\text { Rat } \\
\text { ID } \\
\end{array}$} & \multicolumn{5}{|c|}{ Section } \\
\hline & 1 & 2 & 3 & 4 & 5 \\
\hline 25 & $\begin{array}{l}51 \\
20 \\
25 \\
15 \\
25\end{array}$ & $\begin{array}{r}30 \\
50 \\
24 \\
8 \\
21\end{array}$ & $\begin{array}{l}27 \\
26 \\
30 \\
16 \\
27\end{array}$ & $\begin{array}{l}26 \\
14 \\
16 \\
33 \\
15\end{array}$ & $\begin{array}{r}33 \\
22 \\
8 \\
35 \\
18\end{array}$ \\
\hline 26 & $\begin{array}{l}62 \\
57 \\
43 \\
53 \\
45\end{array}$ & $\begin{array}{r}54 \\
106 \\
52 \\
54 \\
71\end{array}$ & $\begin{array}{l}68 \\
87 \\
48 \\
51 \\
55\end{array}$ & $\begin{array}{l}70 \\
61 \\
40 \\
53 \\
29\end{array}$ & $\begin{array}{l}71 \\
40 \\
41 \\
49 \\
49\end{array}$ \\
\hline 27 & $\begin{array}{r}12 \\
10 \\
8 \\
20 \\
21\end{array}$ & $\begin{array}{r}8 \\
4 \\
15 \\
10 \\
14\end{array}$ & $\begin{array}{l}29 \\
12 \\
16 \\
26 \\
24\end{array}$ & $\begin{array}{l}37 \\
21 \\
31 \\
12 \\
15\end{array}$ & $\begin{array}{l}58 \\
32 \\
20 \\
54 \\
11\end{array}$ \\
\hline 28 & $\begin{array}{l}58 \\
49 \\
40 \\
31 \\
26\end{array}$ & $\begin{array}{l}19 \\
18 \\
17 \\
23 \\
31\end{array}$ & $\begin{array}{l}25 \\
25 \\
19 \\
22 \\
33\end{array}$ & $\begin{array}{l}41 \\
25 \\
25 \\
29 \\
24\end{array}$ & $\begin{array}{l}27 \\
18 \\
40 \\
18 \\
38\end{array}$ \\
\hline 29 & $\begin{array}{r}25 \\
9 \\
17 \\
13 \\
15\end{array}$ & $\begin{array}{r}9 \\
12 \\
10 \\
35 \\
19\end{array}$ & $\begin{array}{l}21 \\
17 \\
11 \\
17 \\
10\end{array}$ & $\begin{array}{r}22 \\
19 \\
17 \\
21 \\
6\end{array}$ & $\begin{array}{r}9 \\
7 \\
11 \\
10 \\
11\end{array}$ \\
\hline 30 & $\begin{array}{r}31 \\
5 \\
37 \\
30 \\
39\end{array}$ & $\begin{array}{l}39 \\
20 \\
31 \\
28 \\
30\end{array}$ & $\begin{array}{l}23 \\
25 \\
31 \\
21 \\
36\end{array}$ & $\begin{array}{l}21 \\
32 \\
33 \\
48 \\
26\end{array}$ & $\begin{array}{l}14 \\
30 \\
42 \\
35 \\
57\end{array}$ \\
\hline 31 & $\begin{array}{l}26 \\
39 \\
35 \\
33 \\
49\end{array}$ & $\begin{array}{l}34 \\
30 \\
36 \\
25 \\
25\end{array}$ & $\begin{array}{l}16 \\
28 \\
26 \\
17 \\
31\end{array}$ & $\begin{array}{l}60 \\
49 \\
23 \\
29 \\
33\end{array}$ & $\begin{array}{l}41 \\
30 \\
27 \\
18 \\
35\end{array}$ \\
\hline 32 & $\begin{array}{l}43 \\
38 \\
24 \\
20 \\
25\end{array}$ & $\begin{array}{l}53 \\
44 \\
34 \\
37 \\
35\end{array}$ & $\begin{array}{l}26 \\
23 \\
49 \\
49 \\
30\end{array}$ & $\begin{array}{l}28 \\
22 \\
61 \\
26 \\
22\end{array}$ & $\begin{array}{l}34 \\
19 \\
28 \\
21 \\
64\end{array}$ \\
\hline
\end{tabular}


TABLE I. 7

MAST CELL COUNT--BONE MARROW

-D DIET

\begin{tabular}{|c|c|c|c|c|c|}
\hline \multirow{2}{*}{$\begin{array}{r}\text { Rat } \\
\text { ID }\end{array}$} & \multicolumn{5}{|c|}{ Section } \\
\hline & 1 & 2 & 3 & 4 & 5 \\
\hline 1 & $\begin{array}{r}0 \\
0 \\
4 \\
75 \\
77\end{array}$ & $\begin{array}{l}36 \\
37 \\
21 \\
60 \\
32\end{array}$ & $\begin{array}{l}16 \\
44 \\
18 \\
65 \\
29\end{array}$ & $\begin{array}{l}22 \\
20 \\
23 \\
15 \\
30\end{array}$ & $\begin{array}{l}38 \\
90 \\
34 \\
24 \\
38\end{array}$ \\
\hline 2 & $\begin{array}{r}16 \\
6 \\
12 \\
14 \\
34\end{array}$ & $\begin{array}{l}23 \\
38 \\
26 \\
23 \\
44\end{array}$ & $\begin{array}{l}17 \\
45 \\
35 \\
39 \\
21\end{array}$ & $\begin{array}{l}31 \\
22 \\
18 \\
11 \\
23\end{array}$ & $\begin{array}{l}47 \\
32 \\
13 \\
58 \\
38\end{array}$ \\
\hline 3 & $\begin{array}{l}23 \\
37 \\
46 \\
67 \\
27\end{array}$ & $\begin{array}{l}63 \\
58 \\
21 \\
38 \\
52\end{array}$ & $\begin{array}{l}41 \\
42 \\
46 \\
19 \\
16\end{array}$ & $\begin{array}{l}51 \\
72 \\
57 \\
80 \\
14\end{array}$ & $\begin{array}{l}19 \\
24 \\
15 \\
22 \\
44\end{array}$ \\
\hline 4 & 19 & $\begin{array}{r}17 \\
4\end{array}$ & & & \\
\hline 5 & $\begin{array}{l}52 \\
31 \\
26 \\
20 \\
20\end{array}$ & $\begin{array}{l}26 \\
31 \\
44 \\
70 \\
66\end{array}$ & $\begin{array}{l}24 \\
29 \\
51 \\
47 \\
64\end{array}$ & $\begin{array}{l}24 \\
39 \\
46 \\
39 \\
27\end{array}$ & $\begin{array}{l}34 \\
20 \\
28 \\
51 \\
59\end{array}$ \\
\hline 6 & $\begin{array}{l}15 \\
15 \\
18 \\
28 \\
18\end{array}$ & $\begin{array}{r}34 \\
20 \\
13 \\
14 \\
7\end{array}$ & $\begin{array}{r}8 \\
19 \\
48 \\
13 \\
35\end{array}$ & $\begin{array}{l}31 \\
32 \\
32 \\
27 \\
26\end{array}$ & $\begin{array}{r}5 \\
26 \\
18 \\
17 \\
19\end{array}$ \\
\hline 7 & & & & & \\
\hline 8 & $\begin{array}{r}2 \\
3 \\
8 \\
33 \\
24\end{array}$ & $\begin{array}{r}10 \\
8 \\
6 \\
12 \\
16\end{array}$ & $\begin{array}{l}15 \\
26 \\
29 \\
21 \\
17\end{array}$ & $\begin{array}{r}56 \\
15 \\
6 \\
10 \\
7\end{array}$ & $\begin{array}{l}10 \\
40 \\
10 \\
13 \\
26\end{array}$ \\
\hline
\end{tabular}


Table I. 7 continued

\begin{tabular}{|c|c|c|c|c|c|}
\hline \multirow{2}{*}{$\begin{array}{r}\text { Rat } \\
\text { ID }\end{array}$} & \multicolumn{5}{|c|}{ Section } \\
\hline & 1 & 2 & 3 & 4 & 5 \\
\hline 9 & $\begin{array}{l}65 \\
84 \\
31 \\
54 \\
41\end{array}$ & $\begin{array}{l}16 \\
29 \\
32 \\
60 \\
44\end{array}$ & $\begin{array}{l}52 \\
56 \\
47 \\
46 \\
42\end{array}$ & $\begin{array}{l}56 \\
24 \\
86 \\
68 \\
44\end{array}$ & $\begin{array}{l}32 \\
80 \\
54 \\
37 \\
58\end{array}$ \\
\hline 10 & $\begin{array}{r}133 \\
63 \\
92 \\
52 \\
101\end{array}$ & $\begin{array}{l}95 \\
88 \\
86 \\
42 \\
69\end{array}$ & $\begin{array}{r}55 \\
83 \\
57 \\
112 \\
90\end{array}$ & $\begin{array}{r}93 \\
76 \\
113 \\
101 \\
70\end{array}$ & $\begin{array}{r}74 \\
85 \\
94 \\
104 \\
116\end{array}$ \\
\hline 11 & $\begin{array}{l}36 \\
42 \\
14 \\
18 \\
35\end{array}$ & $\begin{array}{l}37 \\
39 \\
37 \\
16 \\
32\end{array}$ & $\begin{array}{l}20 \\
18 \\
16 \\
21 \\
16\end{array}$ & $\begin{array}{l}37 \\
24 \\
35 \\
18 \\
15\end{array}$ & \\
\hline 12 & $\begin{array}{l}58 \\
26 \\
52 \\
38 \\
42\end{array}$ & $\begin{array}{l}30 \\
21 \\
16 \\
39 \\
42\end{array}$ & $\begin{array}{l}39 \\
39 \\
32 \\
26 \\
48\end{array}$ & & \\
\hline 13 & $\begin{array}{l}36 \\
46 \\
43 \\
63 \\
38\end{array}$ & $\begin{array}{l}70 \\
17 \\
56 \\
86 \\
56\end{array}$ & $\begin{array}{l}22 \\
16 \\
22 \\
30 \\
36\end{array}$ & $\begin{array}{l}62 \\
22 \\
53 \\
76 \\
30\end{array}$ & $\begin{array}{l}44 \\
27 \\
48 \\
32\end{array}$ \\
\hline 14 & $\begin{array}{l}50 \\
99 \\
79 \\
79 \\
58\end{array}$ & $\begin{array}{l}83 \\
72 \\
67 \\
72 \\
90\end{array}$ & & & \\
\hline 15 & $\begin{array}{r}6 \\
36 \\
24 \\
20 \\
17\end{array}$ & $\begin{array}{r}20 \\
20 \\
14 \\
7 \\
2\end{array}$ & $\begin{array}{r}5 \\
13 \\
30 \\
24 \\
5\end{array}$ & $\begin{array}{l}31 \\
28 \\
26 \\
19 \\
10\end{array}$ & $\begin{array}{l}31 \\
33 \\
26 \\
12 \\
22\end{array}$ \\
\hline
\end{tabular}


Table I. 7 continued

\begin{tabular}{|c|r|r|r|r|r|}
\hline \multirow{2}{*}{ Rat } & \multicolumn{5}{|c|}{ Section } \\
\cline { 2 - 6 } & 1 & 2 & 3 & 4 & 5 \\
\hline \multirow{3}{*}{17} & 45 & 0 & 36 & 12 & 5 \\
& 18 & 0 & 42 & 0 & 34 \\
& 8 & 3 & 29 & 7 & 17 \\
& 32 & 2 & 28 & 29 & 36 \\
& 12 & 26 & 0 & 0 & 22 \\
& & & & &
\end{tabular}

18

19

$\begin{array}{lllll}44 & 35 & 13 & 46 & 24 \\ 36 & 36 & 28 & 45 & 35 \\ 35 & 25 & 39 & 38 & 30 \\ 21 & 10 & 50 & 36 & 38 \\ 35 & 45 & 31 & 23 & 55\end{array}$

20

5

8

4

2

18

9

24

$\begin{array}{rll}18 & 37 & 21 \\ 20 & 11 & 29 \\ 11 & 14 & 23 \\ 5 & 27 & 28 \\ 4 & 21 & 27\end{array}$

21

26

26

25

40

23

73

45

22

21

43

45

32

19

91

64

59

37

34

11

41

33

46

22

9
21
7
4
3

20

15

16

8
10

7
19
21
9
16

22

19

8

9

15

37

23

48

58

60

56

39

63

31

60

30

35

112
70

38

29

75

89

50

47

97

85

2

13

4

12

24

21
34
29
72
82

17
37

21

54

33

14

18

18

20

19
38

55

14

28

63

59

43

37

19

25

17

24

12

38

37

13 
Table I. 7 continued

\begin{tabular}{|c|c|c|c|c|c|}
\hline \multirow{2}{*}{$\begin{array}{r}\text { Rat } \\
\text { ID } \\
\end{array}$} & \multicolumn{5}{|c|}{ Section } \\
\hline & 1 & 2 & 3 & 4 & 5 \\
\hline 25 & $\begin{array}{r}30 \\
11 \\
7 \\
9 \\
11\end{array}$ & $\begin{array}{r}8 \\
28 \\
5 \\
1 \\
3\end{array}$ & $\begin{array}{l}2 \\
2 \\
1 \\
9 \\
1\end{array}$ & 2 & \\
\hline 26 & $\begin{array}{l}21 \\
18 \\
24 \\
50 \\
68\end{array}$ & $\begin{array}{l}28 \\
47 \\
57 \\
46 \\
14\end{array}$ & $\begin{array}{r}20 \\
9 \\
8 \\
8 \\
14\end{array}$ & $\begin{array}{l}32 \\
56 \\
24 \\
46 \\
49\end{array}$ & $\begin{array}{r}104 \\
59 \\
30 \\
50 \\
18\end{array}$ \\
\hline 27 & $\begin{array}{r}15 \\
29 \\
30 \\
8 \\
30\end{array}$ & $\begin{array}{l}19 \\
33 \\
31 \\
13 \\
43\end{array}$ & $\begin{array}{l}16 \\
44 \\
27 \\
36 \\
36\end{array}$ & $\begin{array}{l}15 \\
31 \\
11 \\
11 \\
24\end{array}$ & $\begin{array}{r}29 \\
15 \\
47 \\
32 \\
9\end{array}$ \\
\hline 28 & $\begin{array}{r}9 \\
18 \\
16 \\
14 \\
15\end{array}$ & $\begin{array}{r}2 \\
5 \\
5 \\
10 \\
10\end{array}$ & $\begin{array}{r}7 \\
13 \\
21 \\
15 \\
2\end{array}$ & $\begin{array}{r}12 \\
29 \\
0 \\
18 \\
5\end{array}$ & 11 \\
\hline 29 & $\begin{array}{r}40 \\
17 \\
9 \\
9 \\
30\end{array}$ & $\begin{array}{r}12 \\
47 \\
9 \\
30 \\
10\end{array}$ & $\begin{array}{r}15 \\
24 \\
43 \\
4 \\
16\end{array}$ & $\begin{array}{l}45 \\
14 \\
22 \\
16 \\
16\end{array}$ & $\begin{array}{l}26 \\
33\end{array}$ \\
\hline 30 & $\begin{array}{r}3 \\
34 \\
10 \\
21 \\
28\end{array}$ & $\begin{array}{l}40 \\
18 \\
44 \\
54 \\
24\end{array}$ & & & \\
\hline 31 & $\begin{array}{l}2 \\
1 \\
2 \\
0 \\
2\end{array}$ & $\begin{array}{r}9 \\
14 \\
7 \\
16 \\
9\end{array}$ & $\begin{array}{r}10 \\
26 \\
10 \\
4 \\
3\end{array}$ & $\begin{array}{r}14 \\
1 \\
14 \\
2 \\
3\end{array}$ & $\begin{array}{r}6 \\
19 \\
2 \\
3 \\
5\end{array}$ \\
\hline 32 & $\begin{array}{r}36 \\
21 \\
11 \\
9 \\
18\end{array}$ & $\begin{array}{l}24 \\
26 \\
26 \\
45 \\
63\end{array}$ & $\begin{array}{l}55 \\
48 \\
42 \\
58 \\
30\end{array}$ & $\begin{array}{l}20 \\
22 \\
23 \\
36 \\
26\end{array}$ & $\begin{array}{l}36 \\
17 \\
37 \\
46 \\
58\end{array}$ \\
\hline
\end{tabular}


TABLE I. 8

MAST CELL COUNT--BONE MARROW

$$
\text { -CA, -D DIET }
$$

\begin{tabular}{|c|c|c|c|c|c|}
\hline \multirow{2}{*}{$\begin{array}{r}\text { Rat } \\
\text { ID } \\
\end{array}$} & \multicolumn{5}{|c|}{ Section } \\
\hline & 1 & 2 & 3 & 4 & 5 \\
\hline 1 & $\begin{array}{l}30 \\
27 \\
85 \\
70 \\
69\end{array}$ & $\begin{array}{l}57 \\
39 \\
33 \\
39 \\
50\end{array}$ & $\begin{array}{l}42 \\
51 \\
43 \\
56 \\
57\end{array}$ & $\begin{array}{l}28 \\
12 \\
32 \\
43 \\
23\end{array}$ & $\begin{array}{l}15 \\
26 \\
16 \\
47 \\
38\end{array}$ \\
\hline 2 & $\begin{array}{l}19 \\
11 \\
35 \\
13 \\
35\end{array}$ & $\begin{array}{r}34 \\
6 \\
17 \\
25 \\
25\end{array}$ & $\begin{array}{r}9 \\
31 \\
43 \\
13 \\
45\end{array}$ & $\begin{array}{l}33 \\
18 \\
21 \\
20\end{array}$ & $\begin{array}{l}11 \\
23 \\
20 \\
25 \\
19\end{array}$ \\
\hline 3 & $\begin{array}{l}25 \\
22 \\
15 \\
33 \\
19\end{array}$ & $\begin{array}{l}65 \\
55 \\
24 \\
56 \\
18\end{array}$ & $\begin{array}{l}37 \\
24 \\
20 \\
19 \\
11\end{array}$ & $\begin{array}{l}53 \\
59 \\
23 \\
19 \\
45\end{array}$ & $\begin{array}{l}23 \\
18 \\
14 \\
21 \\
17\end{array}$ \\
\hline 4 & $\begin{array}{l}23 \\
18 \\
23 \\
41 \\
39\end{array}$ & $\begin{array}{l}18 \\
33 \\
32 \\
26 \\
34\end{array}$ & $\begin{array}{l}33 \\
31 \\
49 \\
38 \\
20\end{array}$ & $\begin{array}{l}60 \\
51 \\
50 \\
21 \\
14\end{array}$ & $\begin{array}{l}16 \\
49 \\
64 \\
52 \\
63\end{array}$ \\
\hline 5 & $\begin{array}{l}28 \\
69 \\
12 \\
32 \\
22\end{array}$ & $\begin{array}{l}39 \\
45 \\
24 \\
60 \\
62\end{array}$ & $\begin{array}{l}39 \\
17 \\
37 \\
31 \\
37\end{array}$ & $\begin{array}{l}25 \\
17 \\
37 \\
41 \\
29\end{array}$ & $\begin{array}{l}21 \\
38 \\
27 \\
33 \\
42\end{array}$ \\
\hline 6 & $\begin{array}{l}31 \\
23 \\
21 \\
33 \\
34\end{array}$ & $\begin{array}{l}35 \\
38 \\
38 \\
43 \\
28\end{array}$ & $\begin{array}{l}15 \\
22 \\
37 \\
16 \\
17\end{array}$ & $\begin{array}{l}46 \\
50 \\
39 \\
30 \\
42\end{array}$ & $\begin{array}{l}31 \\
25 \\
31 \\
15 \\
48\end{array}$ \\
\hline 7 & $\begin{array}{r}17 \\
4 \\
14 \\
8 \\
42\end{array}$ & $\begin{array}{l}35 \\
15 \\
22 \\
10 \\
57\end{array}$ & $\begin{array}{r}14 \\
16 \\
3 \\
7 \\
4\end{array}$ & $\begin{array}{l}14 \\
12 \\
13 \\
22 \\
15\end{array}$ & $\begin{array}{l}13 \\
12 \\
28 \\
20 \\
13\end{array}$ \\
\hline 8 & $\begin{array}{l}21 \\
10 \\
15 \\
40 \\
30\end{array}$ & $\begin{array}{l}15 \\
14 \\
28 \\
23 \\
23\end{array}$ & $\begin{array}{r}20 \\
25 \\
5 \\
34 \\
31\end{array}$ & $\begin{array}{l}23 \\
28 \\
22 \\
15 \\
22\end{array}$ & $\begin{array}{l}50 \\
36 \\
43 \\
37 \\
38\end{array}$ \\
\hline
\end{tabular}


Table I. 8 continued

\begin{tabular}{|c|c|c|c|c|c|}
\hline \multirow{2}{*}{$\begin{array}{r}\text { Rat } \\
\text { ID }\end{array}$} & \multicolumn{5}{|c|}{ Section } \\
\hline & 1 & 2 & 3 & 4 & 5 \\
\hline 9 & $\begin{array}{l}28 \\
34 \\
25 \\
23 \\
13\end{array}$ & $\begin{array}{l}10 \\
19 \\
25 \\
20 \\
17\end{array}$ & $\begin{array}{r}17 \\
17 \\
8 \\
9 \\
13\end{array}$ & $\begin{array}{r}39 \\
37 \\
25 \\
9 \\
11\end{array}$ & $\begin{array}{r}25 \\
9 \\
29 \\
7 \\
12\end{array}$ \\
\hline 10 & $\begin{array}{l}26 \\
14 \\
32 \\
17 \\
20\end{array}$ & $\begin{array}{l}46 \\
15 \\
16 \\
36 \\
23\end{array}$ & $\begin{array}{l}35 \\
32 \\
40 \\
19 \\
43\end{array}$ & $\begin{array}{l}47 \\
18 \\
34 \\
21 \\
24\end{array}$ & $\begin{array}{l}35 \\
48 \\
27 \\
33 \\
37\end{array}$ \\
\hline 11 & $\begin{array}{l}29 \\
13 \\
34 \\
44 \\
38\end{array}$ & $\begin{array}{l}19 \\
20 \\
43 \\
37 \\
31\end{array}$ & $\begin{array}{l}35 \\
23 \\
51 \\
40 \\
32\end{array}$ & $\begin{array}{l}34 \\
25 \\
40 \\
20 \\
30\end{array}$ & $\begin{array}{l}24 \\
31 \\
26 \\
33 \\
25\end{array}$ \\
\hline 12 & $\begin{array}{l}15 \\
21 \\
17 \\
24 \\
25\end{array}$ & $\begin{array}{l}12 \\
14 \\
15 \\
21 \\
37\end{array}$ & $\begin{array}{l}17 \\
10 \\
14 \\
17 \\
22\end{array}$ & $\begin{array}{l}10 \\
15 \\
12 \\
15 \\
19\end{array}$ & $\begin{array}{l}14 \\
13 \\
14 \\
14 \\
21\end{array}$ \\
\hline 13 & $\begin{array}{l}23 \\
23 \\
23 \\
33 \\
35\end{array}$ & & & & \\
\hline 14 & $\begin{array}{r}11 \\
7 \\
9 \\
13 \\
16\end{array}$ & $\begin{array}{r}7 \\
10 \\
7 \\
16 \\
26\end{array}$ & $\begin{array}{r}58 \\
15 \\
10 \\
37 \\
9\end{array}$ & $\begin{array}{l}14 \\
37 \\
16 \\
19 \\
34\end{array}$ & $\begin{array}{r}55 \\
15 \\
17 \\
7 \\
23\end{array}$ \\
\hline 15 & $\begin{array}{l}24 \\
21 \\
16 \\
15 \\
24\end{array}$ & $\begin{array}{l}17 \\
20 \\
27 \\
27 \\
25\end{array}$ & $\begin{array}{l}12 \\
27 \\
14 \\
16 \\
16\end{array}$ & $\begin{array}{l}20 \\
20 \\
14 \\
20 \\
27\end{array}$ & $\begin{array}{l}20 \\
23 \\
14 \\
22 \\
20\end{array}$ \\
\hline 16 & $\begin{array}{l}13 \\
27 \\
29 \\
26 \\
30\end{array}$ & $\begin{array}{r}21 \\
26 \\
26 \\
15 \\
8\end{array}$ & $\begin{array}{l}17 \\
20 \\
11 \\
25 \\
10\end{array}$ & $\begin{array}{r}52 \\
60 \\
34 \\
26 \\
5\end{array}$ & $\begin{array}{r}30 \\
8 \\
7 \\
8 \\
18\end{array}$ \\
\hline
\end{tabular}


Table I. 8 continued

\begin{tabular}{|c|c|c|c|c|c|}
\hline \multirow{2}{*}{$\begin{array}{r}\text { Rat } \\
\text { ID }\end{array}$} & \multicolumn{5}{|c|}{ Section } \\
\hline & 1 & 2 & 3 & 4 & 5 \\
\hline 17 & $\begin{array}{l}40 \\
14 \\
37 \\
67 \\
32\end{array}$ & $\begin{array}{l}28 \\
11 \\
34 \\
24 \\
38\end{array}$ & $\begin{array}{l}14 \\
23 \\
46 \\
20 \\
35\end{array}$ & $\begin{array}{l}28 \\
16 \\
24 \\
14 \\
11\end{array}$ & $\begin{array}{l}15 \\
22 \\
17 \\
16 \\
14\end{array}$ \\
\hline 18 & $\begin{array}{l}49 \\
32 \\
20 \\
19 \\
18\end{array}$ & $\begin{array}{l}54 \\
19 \\
15 \\
14 \\
15\end{array}$ & $\begin{array}{r}27 \\
11 \\
11 \\
8 \\
12\end{array}$ & $\begin{array}{r}10 \\
15 \\
14 \\
9 \\
24\end{array}$ & $\begin{array}{l}19 \\
10 \\
16 \\
16 \\
11\end{array}$ \\
\hline 19 & $\begin{array}{l}29 \\
50 \\
27 \\
23 \\
51\end{array}$ & $\begin{array}{l}38 \\
17 \\
28 \\
27 \\
16\end{array}$ & $\begin{array}{l}23 \\
53 \\
23 \\
17 \\
45\end{array}$ & $\begin{array}{r}36 \\
39 \\
22 \\
33 \\
2\end{array}$ & $\begin{array}{l}31 \\
43 \\
49 \\
43 \\
30\end{array}$ \\
\hline 20 & $\begin{array}{l}20 \\
37 \\
40 \\
41 \\
35\end{array}$ & $\begin{array}{l}78 \\
30 \\
28 \\
63 \\
64\end{array}$ & $\begin{array}{l}31 \\
48 \\
23 \\
26 \\
23\end{array}$ & $\begin{array}{l}14 \\
18 \\
32 \\
28 \\
28\end{array}$ & $\begin{array}{l}40 \\
23 \\
25 \\
31 \\
52\end{array}$ \\
\hline 21 & $\begin{array}{r}16 \\
110 \\
35 \\
51 \\
33\end{array}$ & $\begin{array}{l}79 \\
39 \\
57 \\
52 \\
67\end{array}$ & $\begin{array}{l}12 \\
23 \\
26 \\
53 \\
23\end{array}$ & $\begin{array}{l}16 \\
20 \\
17 \\
18 \\
24\end{array}$ & $\begin{array}{r}7 \\
21 \\
50 \\
26 \\
22\end{array}$ \\
\hline 22 & $\begin{array}{r}23 \\
8 \\
14 \\
11 \\
15\end{array}$ & $\begin{array}{r}6 \\
11 \\
11 \\
6 \\
17\end{array}$ & $\begin{array}{r}14 \\
35 \\
30 \\
10 \\
5\end{array}$ & $\begin{array}{r}20 \\
9 \\
33 \\
15 \\
69\end{array}$ & $\begin{array}{l}92 \\
71\end{array}$ \\
\hline 23 & $\begin{array}{l}19 \\
26 \\
30 \\
16 \\
13\end{array}$ & $\begin{array}{l}11 \\
11 \\
11 \\
18 \\
12\end{array}$ & $\begin{array}{l}24 \\
15 \\
66 \\
29 \\
27\end{array}$ & $\begin{array}{r}20 \\
9 \\
20 \\
29 \\
41\end{array}$ & $\begin{array}{l}18 \\
19 \\
17 \\
18 \\
25\end{array}$ \\
\hline 24 & $\begin{array}{l}18 \\
28 \\
24 \\
33 \\
19\end{array}$ & $\begin{array}{l}19 \\
29 \\
46 \\
36 \\
19\end{array}$ & $\begin{array}{l}24 \\
51 \\
25 \\
24 \\
27\end{array}$ & $\begin{array}{l}21 \\
27 \\
18 \\
54 \\
27\end{array}$ & $\begin{array}{l}42 \\
51 \\
39 \\
47 \\
26\end{array}$ \\
\hline
\end{tabular}


Table I. 8 continued

\begin{tabular}{|c|c|c|c|c|c|}
\hline Rat & \multicolumn{5}{|c|}{ Section } \\
\cline { 2 - 6 } ID & 1 & 2 & 3 & 4 & 5 \\
\hline \multirow{2}{*}{25} & 22 & 27 & 53 & 22 & 22 \\
& 26 & 37 & 57 & 35 & 39 \\
& 43 & 45 & 60 & 75 & 36 \\
& 19 & 23 & 57 & 26 & 27 \\
& 23 & 43 & 40 & 37 & 20
\end{tabular}

26

27

$\begin{array}{rll}5 & 70 & 16 \\ 8 & 42 & 32 \\ 15 & 16 & 50 \\ 20 & 49 & \\ 41 & 18 & \end{array}$

28

$\begin{array}{rrrrr}23 & 28 & 28 & 27 & 67 \\ 10 & 22 & 11 & 8 & 20 \\ 22 & 32 & 29 & 10 & 12 \\ 100 & 26 & 23 & 13 & 20 \\ 20 & 66 & 25 & 33 & 19\end{array}$

29

153

72

61

78

123

84

78

143

78

74

59

103

62

75

92

59

80

30

38

60

39

46

32

12

28

35

45

32

26

43

31

111
48
38
56
62

32

$\begin{array}{ll}66 & 17 \\ 17 & 52 \\ 27 & 14 \\ 31 & 13 \\ 57 & 21\end{array}$

68

92

58

50

97

9

13

98

17

52

14

13

70

58

76

50

58

37

61

50

33

36

20

12

19

21

33

14

36

25

75

59

89

68

47

26

69

25

34

21

63

35

44

45

34

65

43

80

44

110

17
56
25
48
39




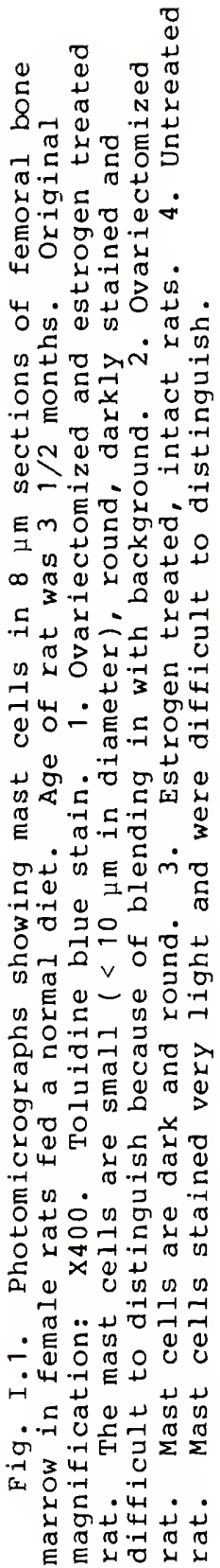



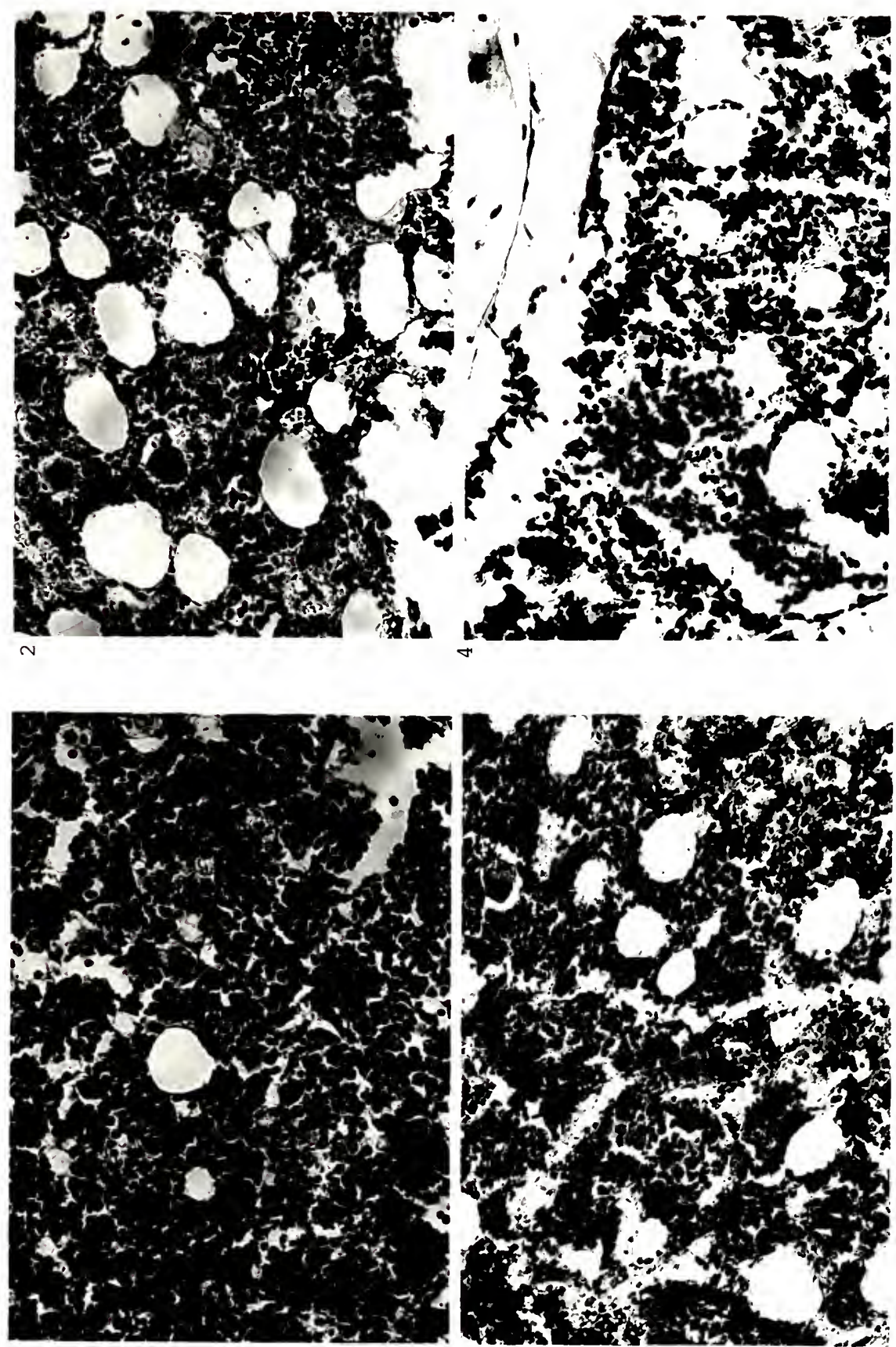
ํ.

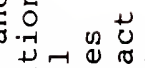

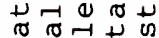

\% 0.5.

H.न

-1 4 or

ब.

पे

(4)

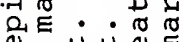

ब

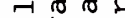

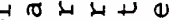

0 工

- 50

๙

I.

० प्रा त

-

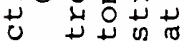

ข. U 되

का द

ब $4 \cdot \pi$.

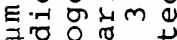

$\infty+$ 岑分.

$+\underbrace{}_{0} 0$

$=$ व 0 व

Uण $\sim$ 员

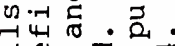

$\rightarrow 00$

Ð

E N.न का

म

ט.

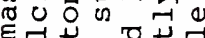

ช $0>\geq 0$

करण बत्न म्न

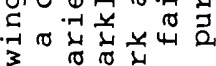

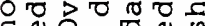

धथ

•

थ $n-$ 元

टा

तथ $\rightarrow$

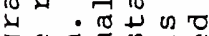

ดथ ¿

तनन ध

崩

-

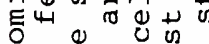

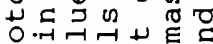

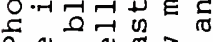

م

in 5 क्ष

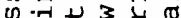

N.

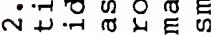

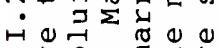

$>0$ E E

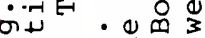

- 0 i

द 0.50 ज

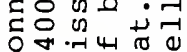

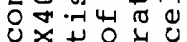



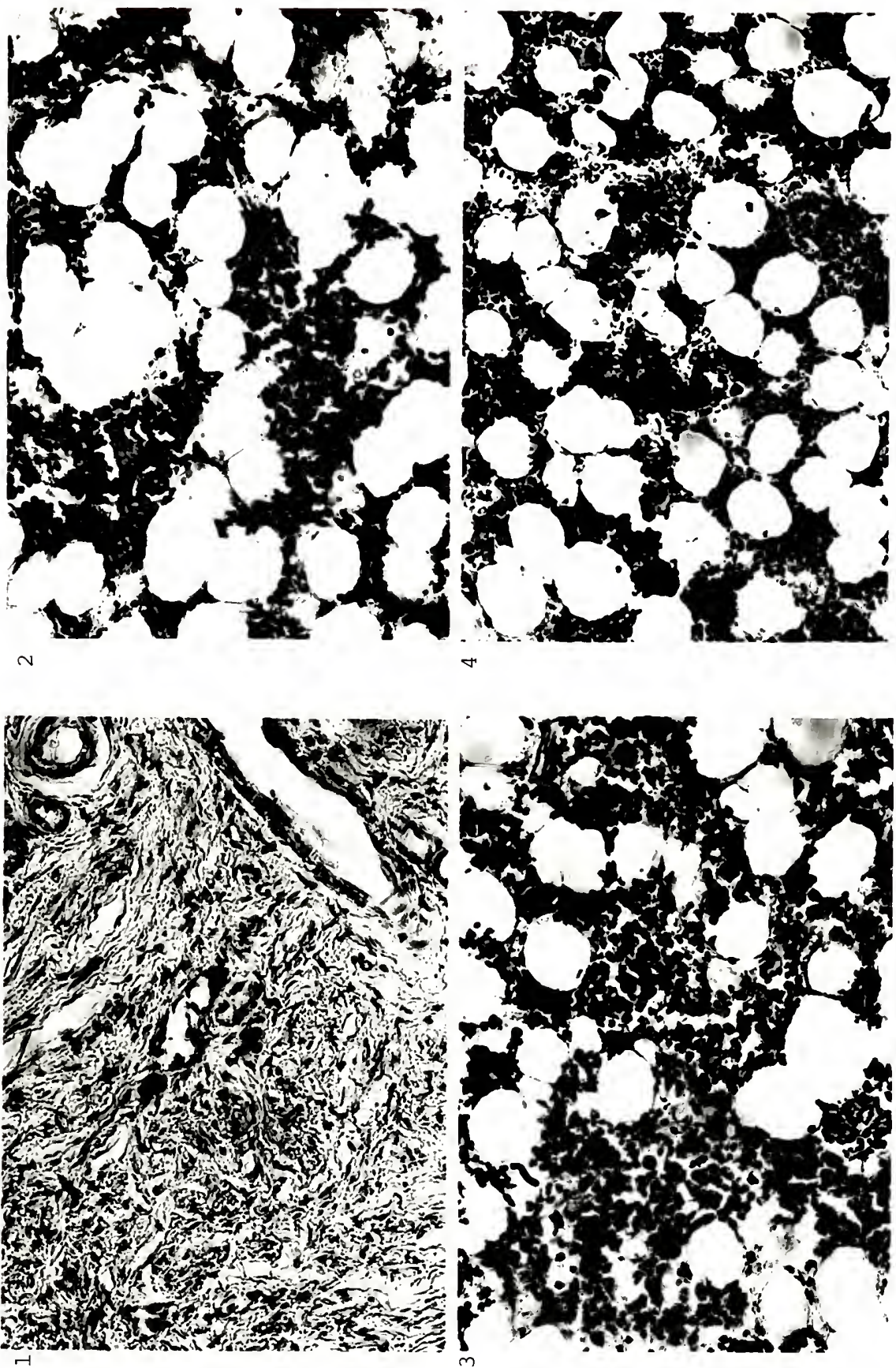


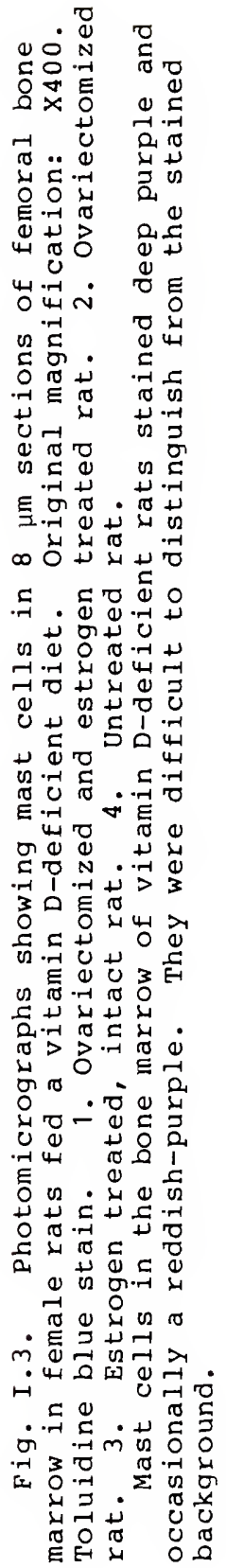



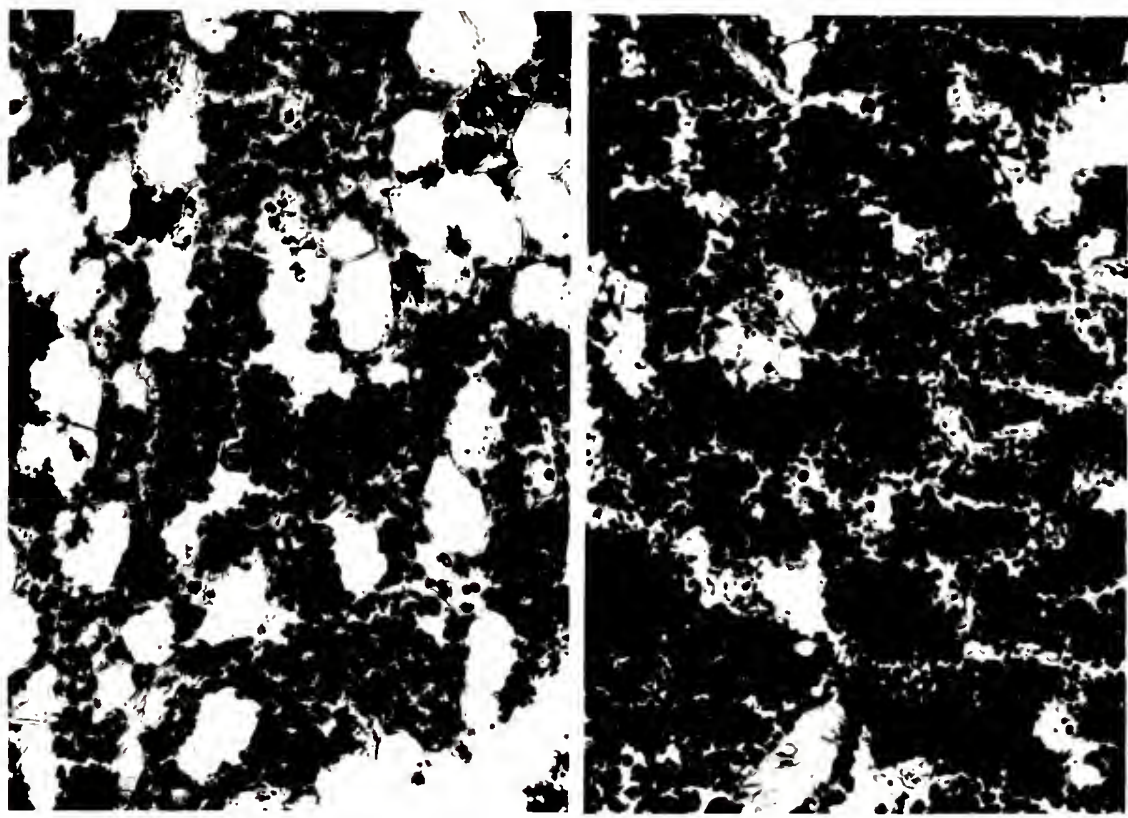

N

$+$

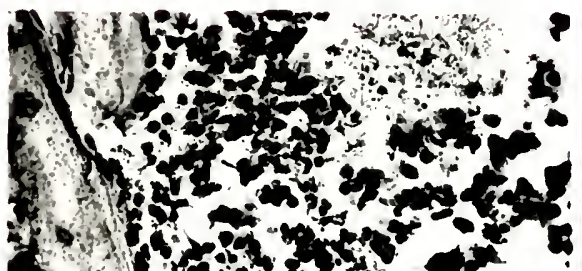
1. + t to

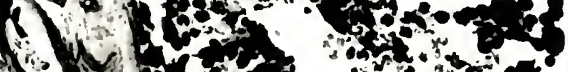

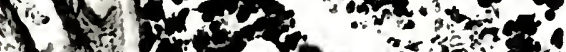

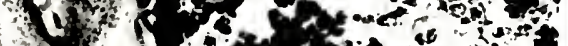

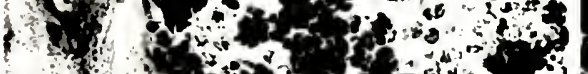

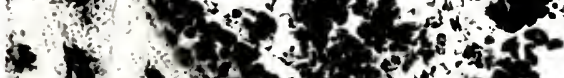

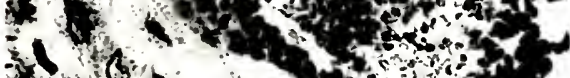

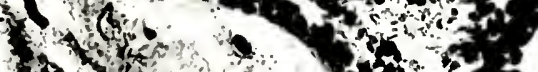

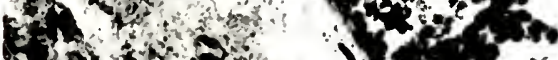

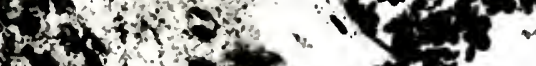

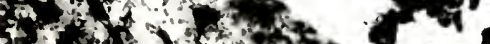

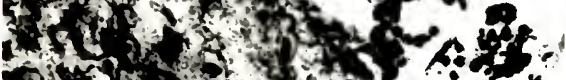
andx

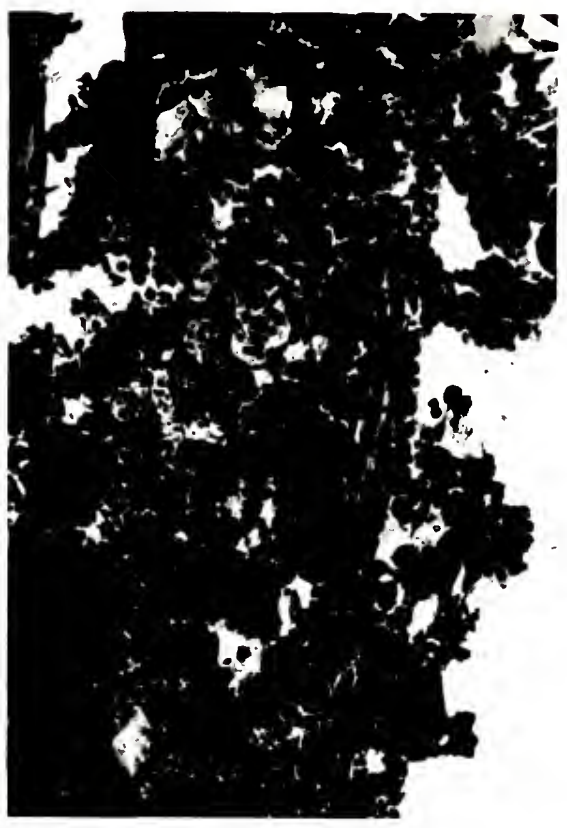

- 


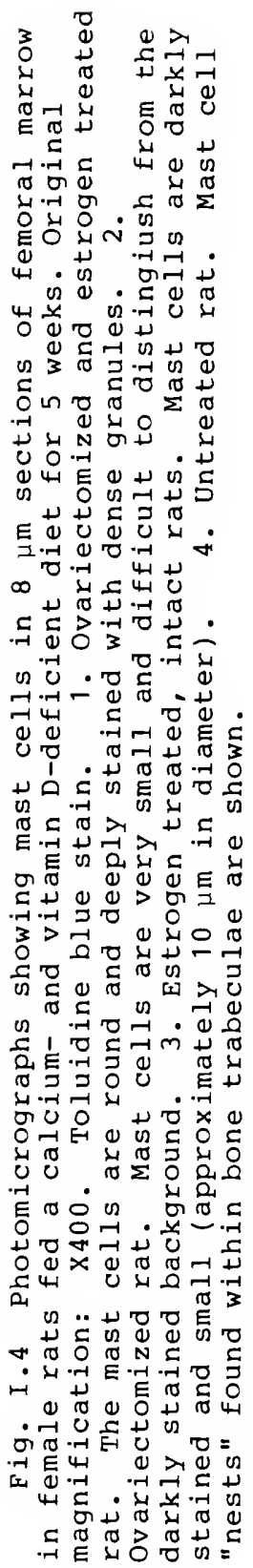




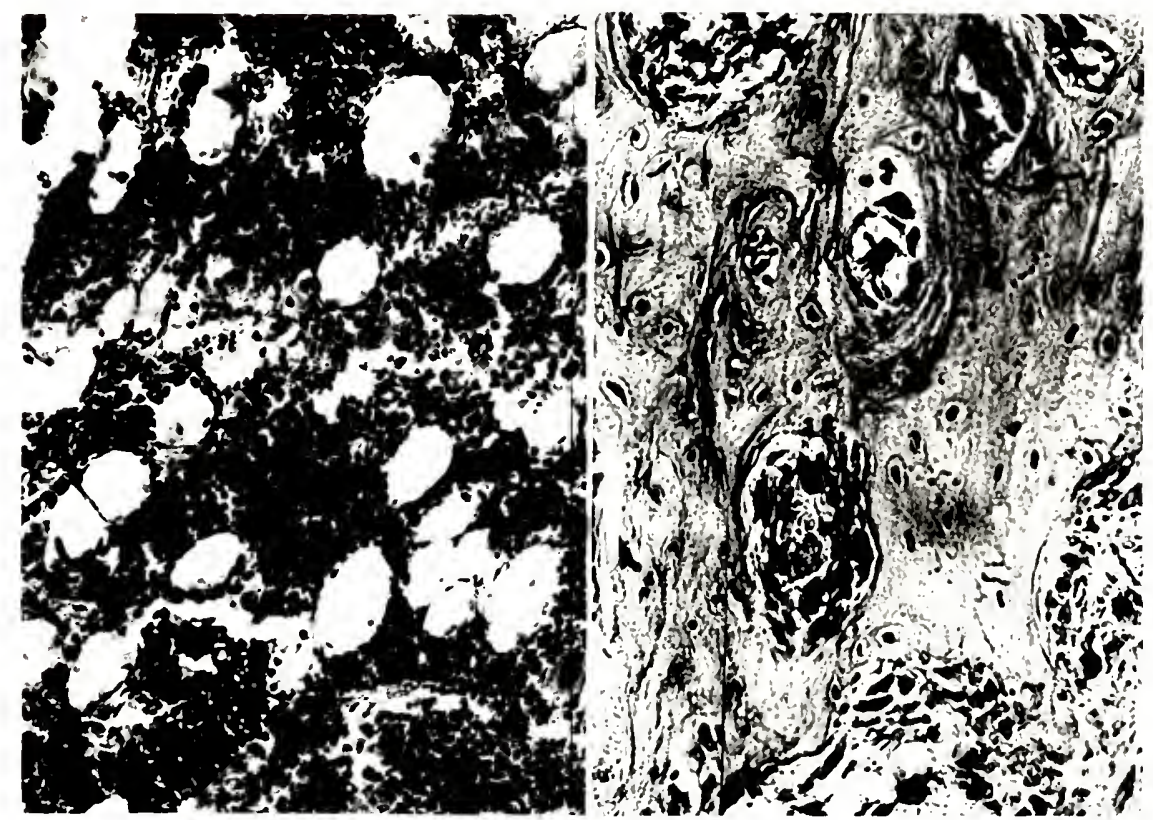

N

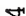
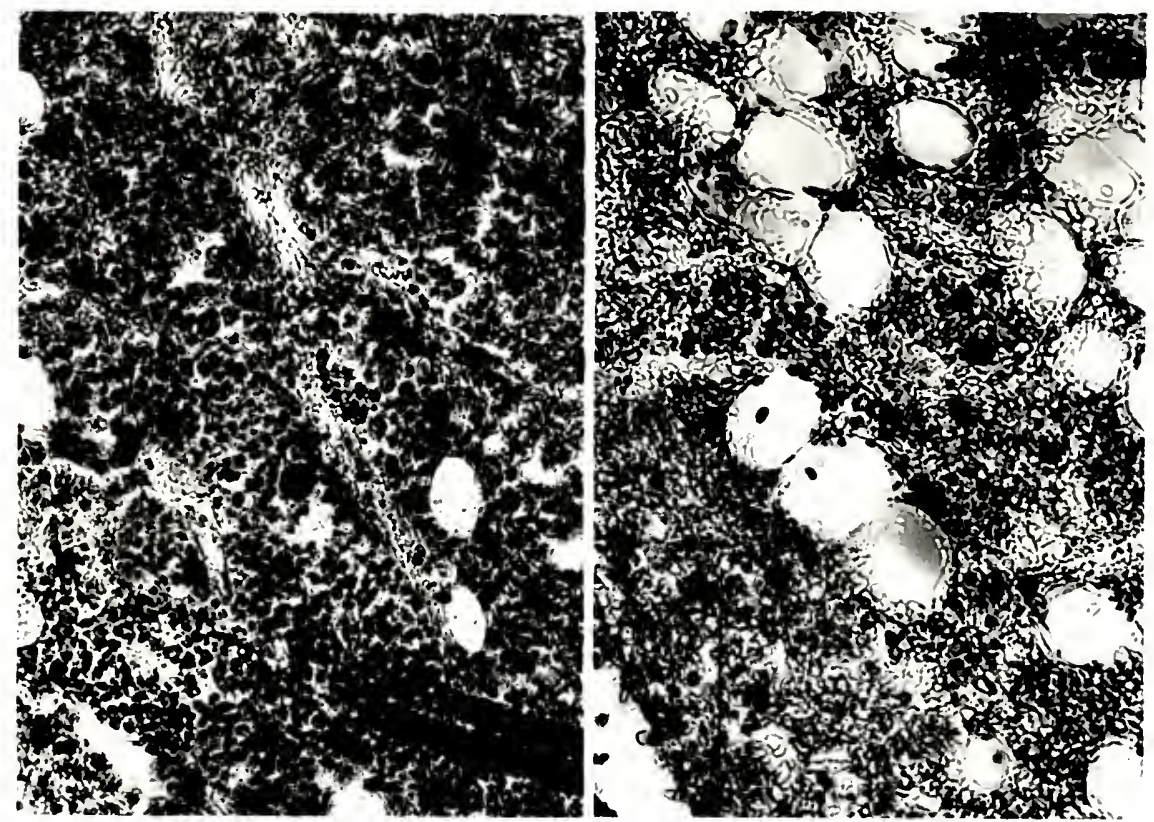


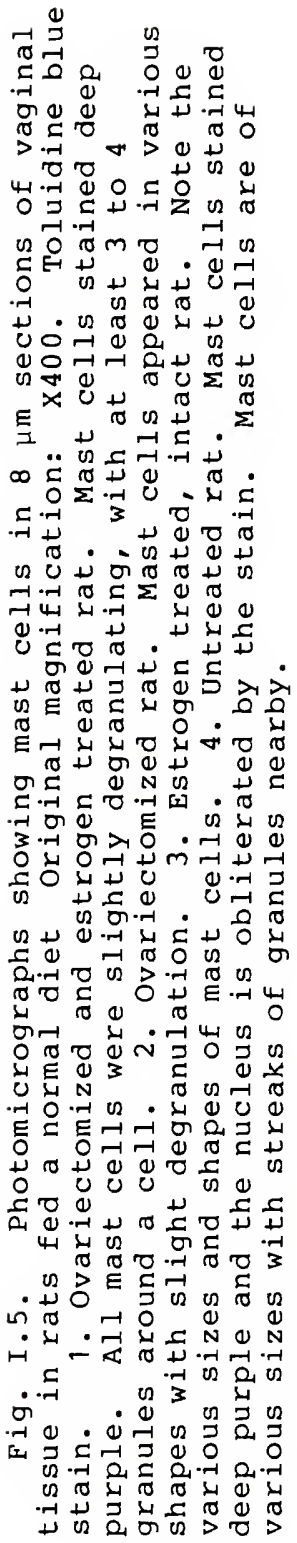




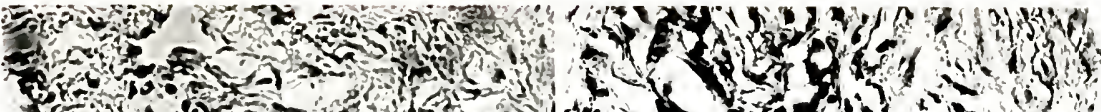

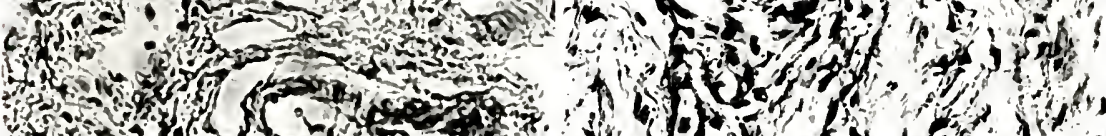

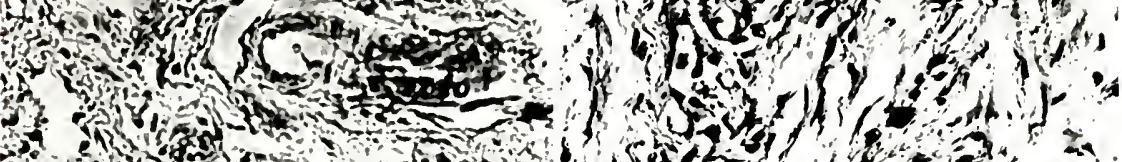

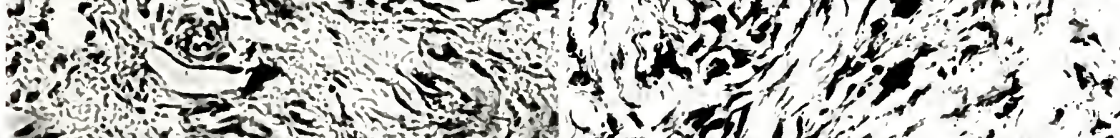

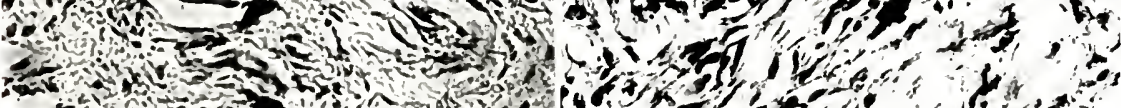

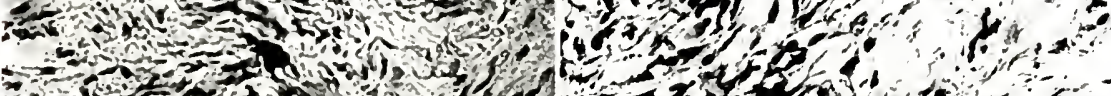

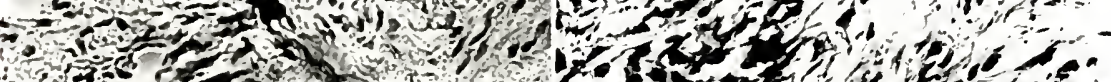

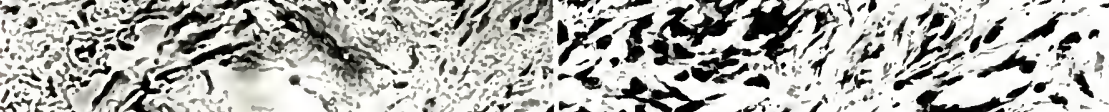
sif

7. 5 fu

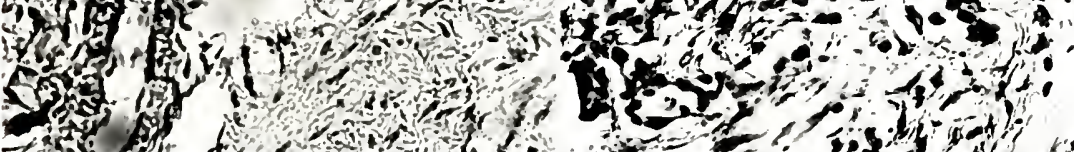

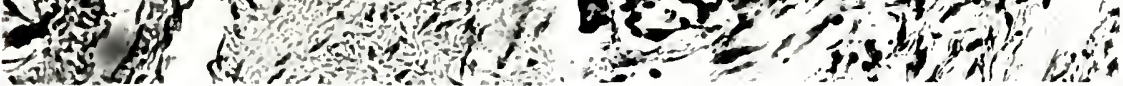

N

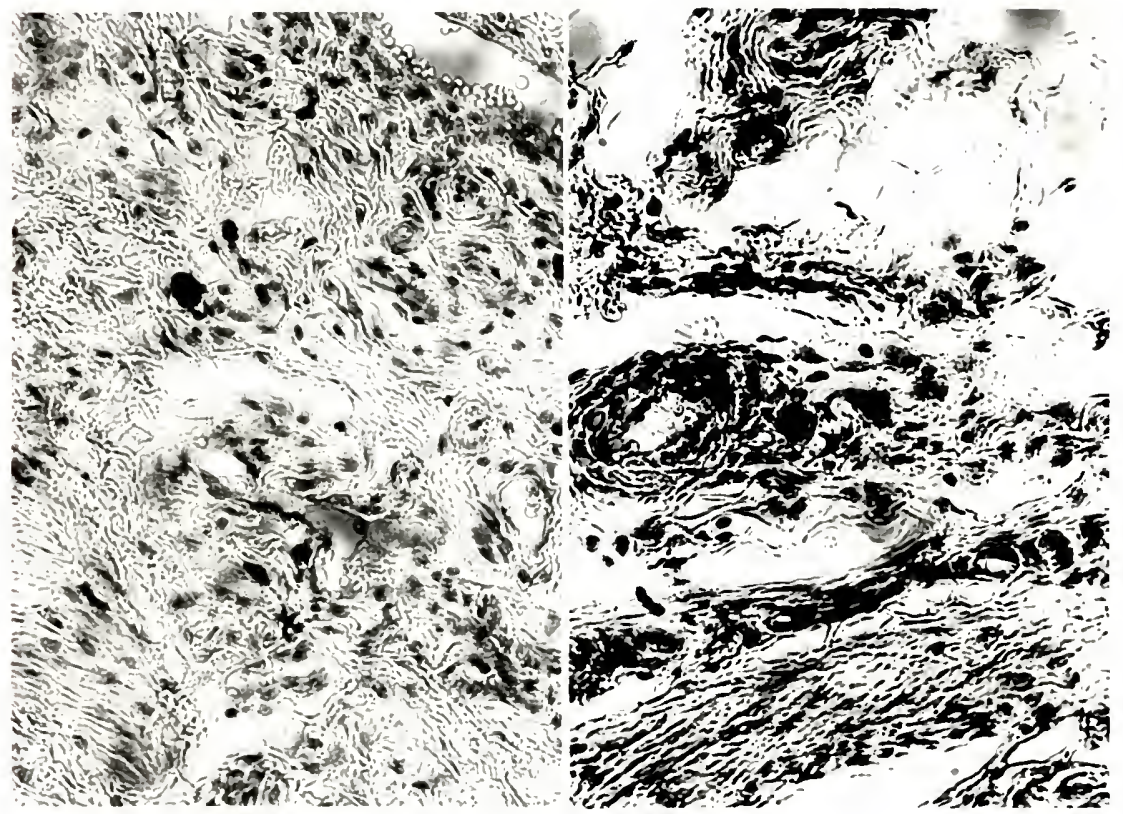




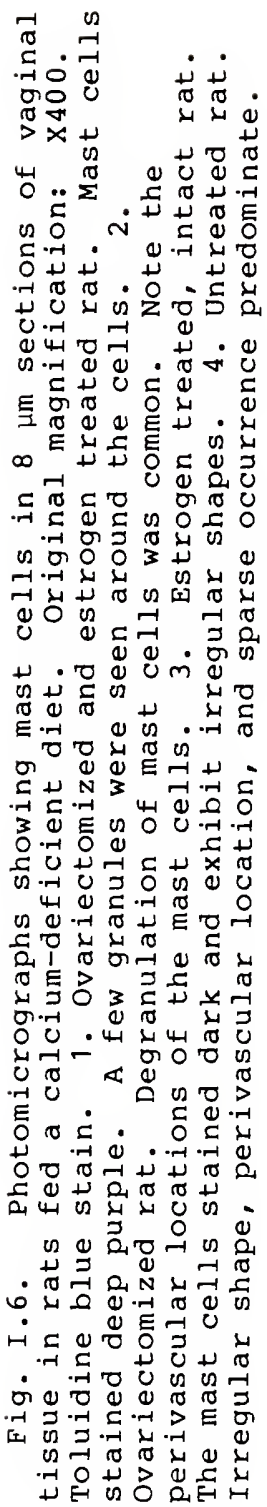




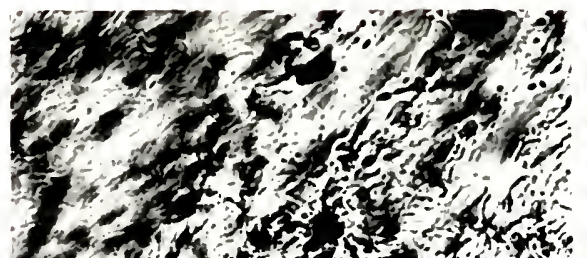

(1) f thes? 14. (1) कs

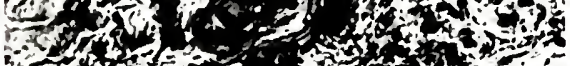
$3{ }^{2}$ (3)

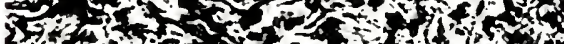

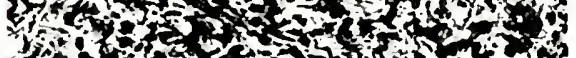

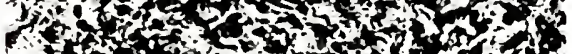
ciste $N$

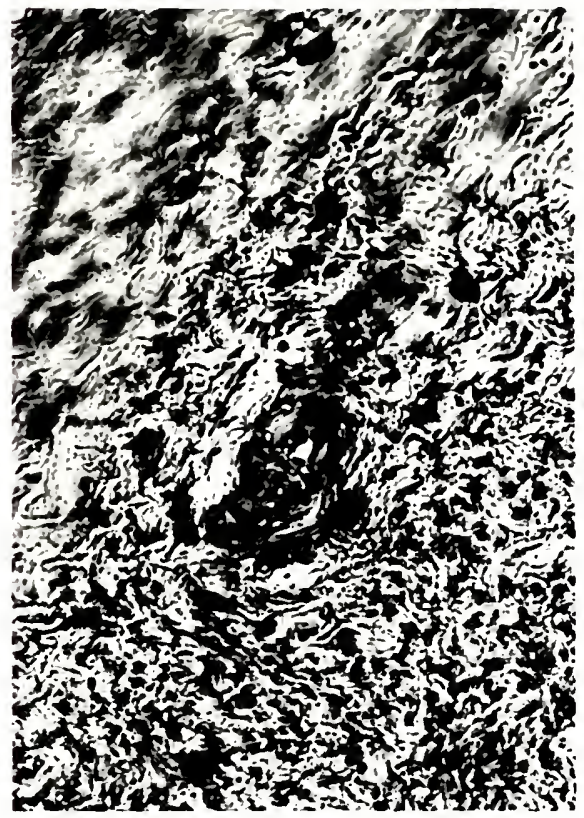

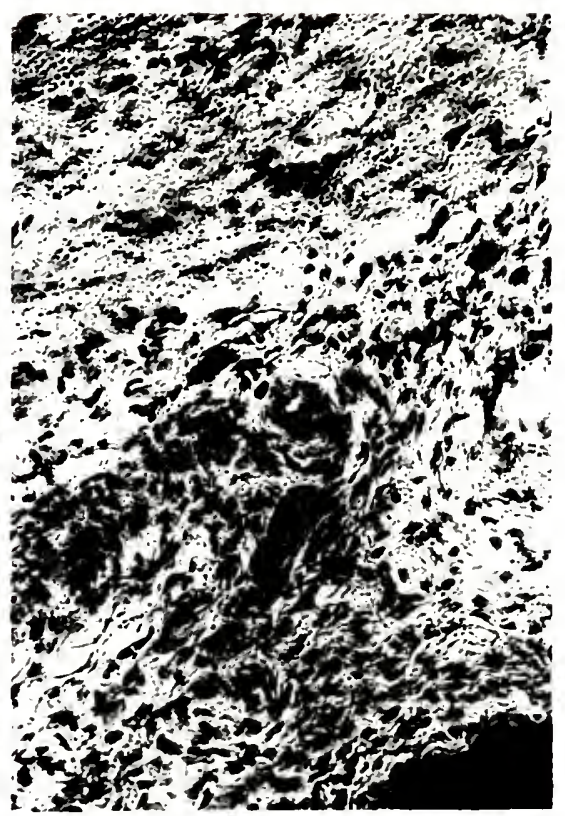

$\nabla$

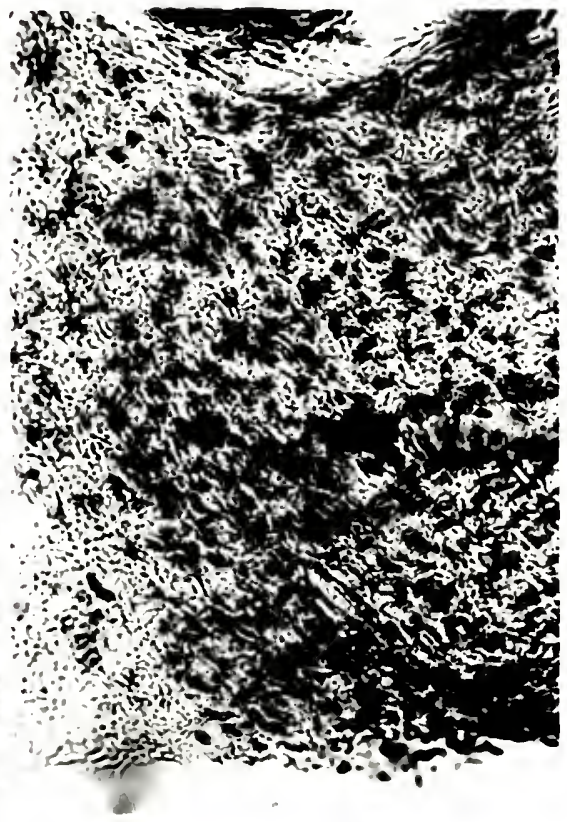




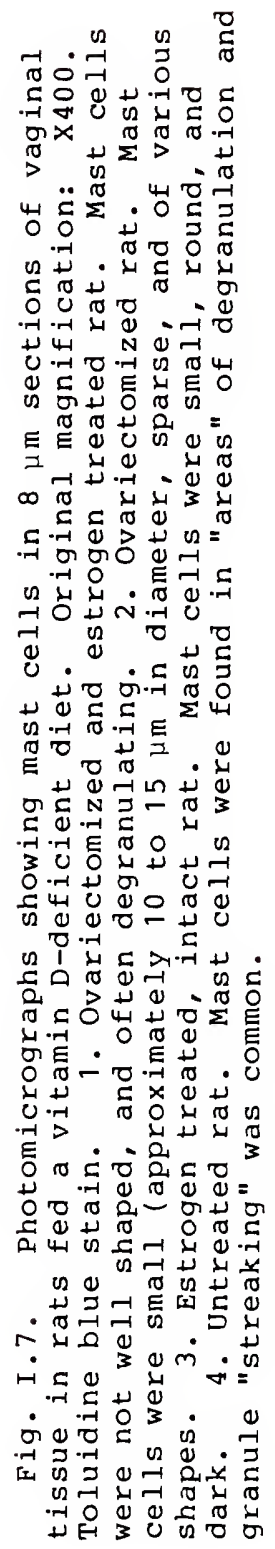



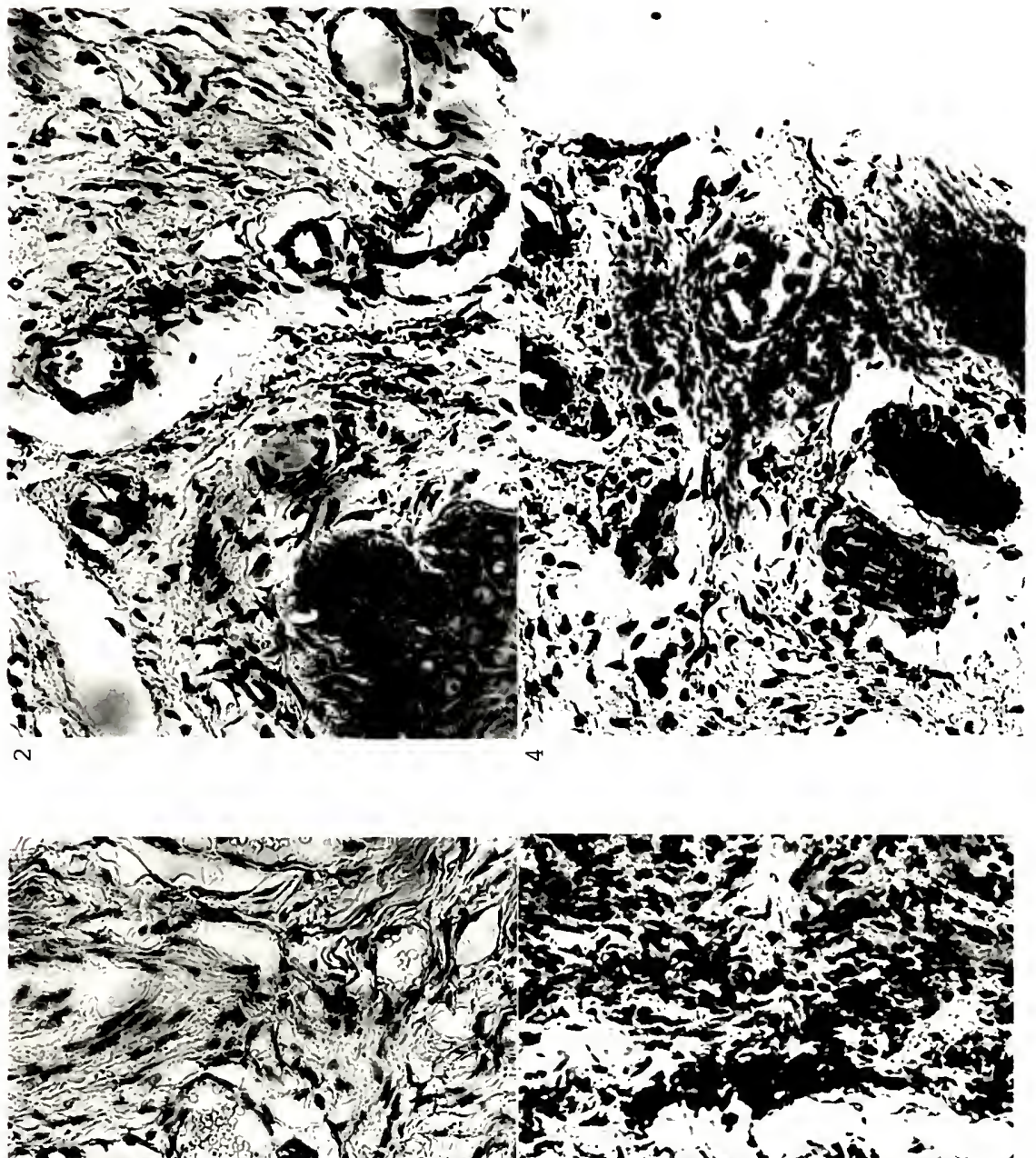

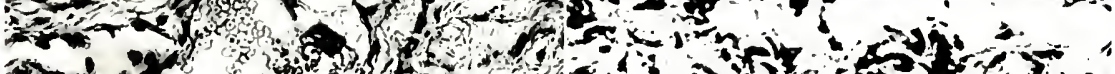

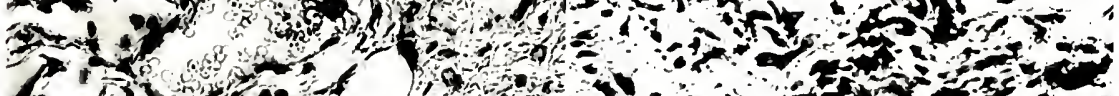

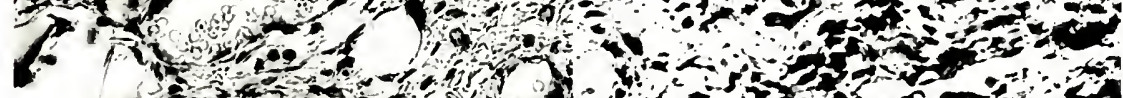

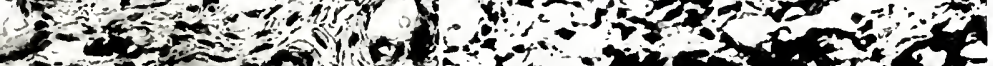

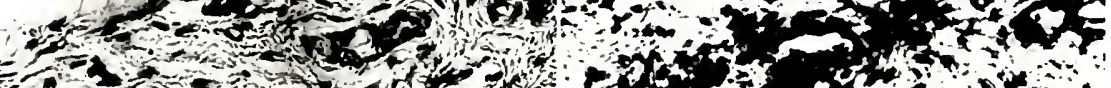

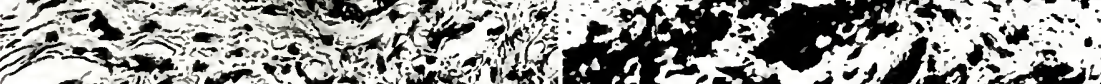

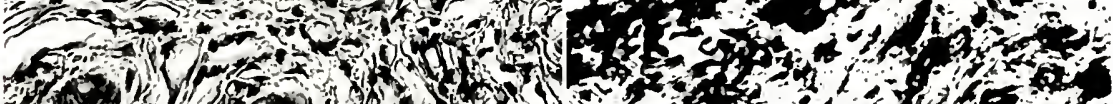

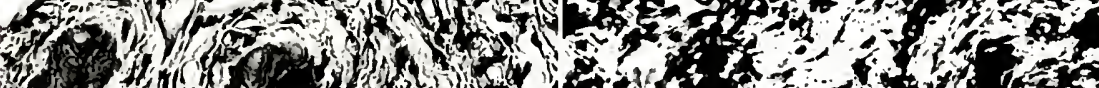

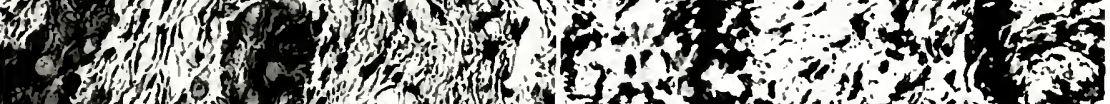
(1) 


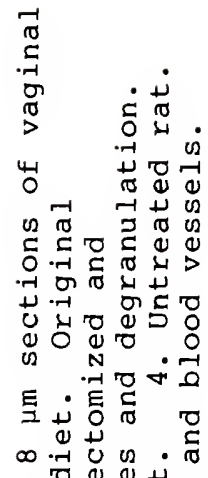

त 04

. ट क वे क $\Rightarrow$ च ष.न.

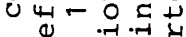
म os 10

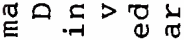
$=\pi+\stackrel{0}{0}$ ब.न E ह

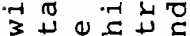

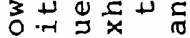

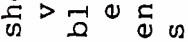
ㅁ क ०

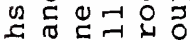

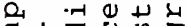
$\pi 1000$ 내다 되 Oت पर० 0 rom 0 U $\mathrm{E} \Sigma$ $\rightarrow \pi$ हू 0.00 $+\pi 0 \dot{0}$ 0 웅 赵 4 व U $\infty$ - मे ل्र $-4+00$

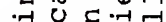

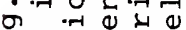

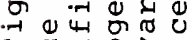
is $כ$. is 5 प्र० जक का थ

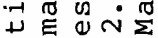




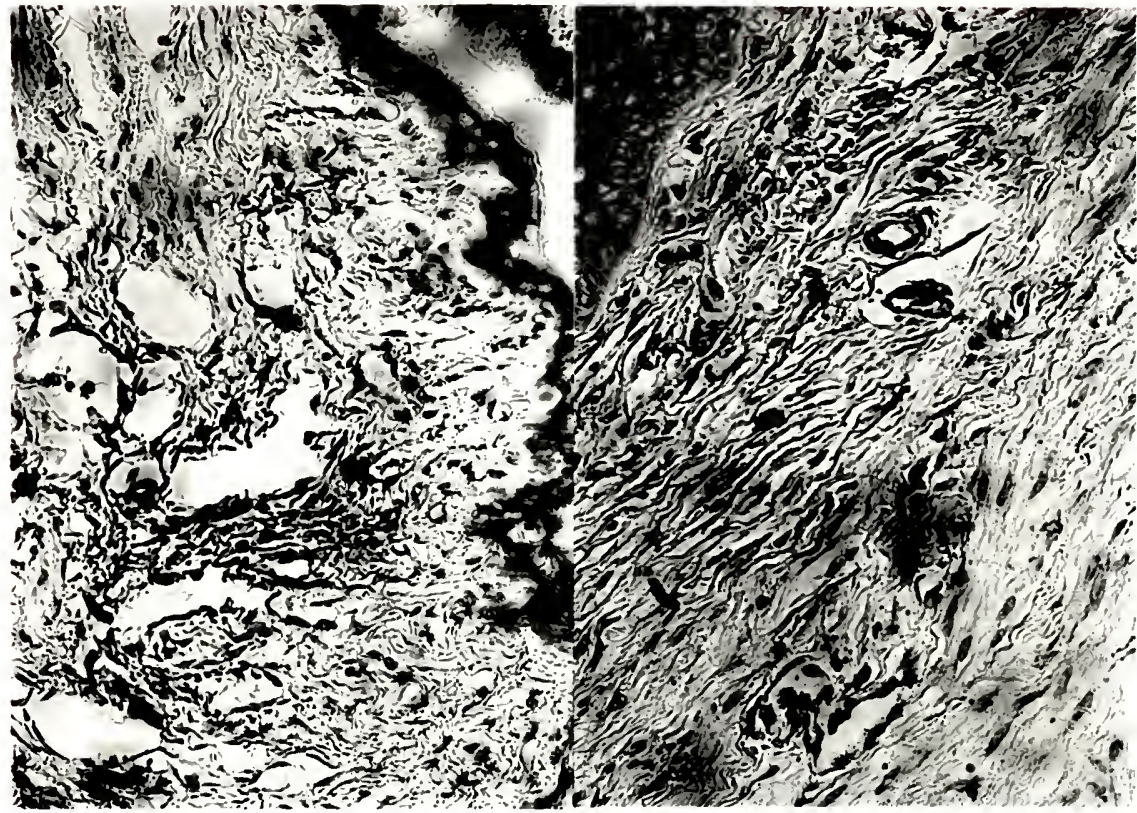

N

3. - 1 s 4 (1)

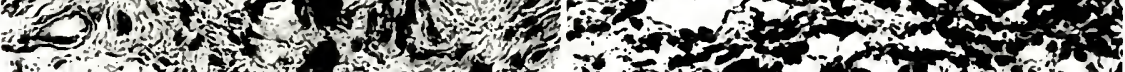

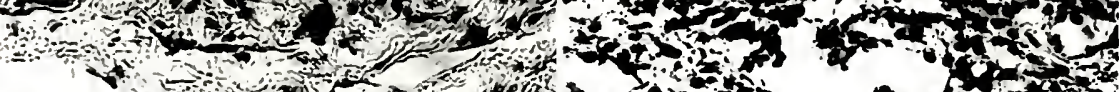

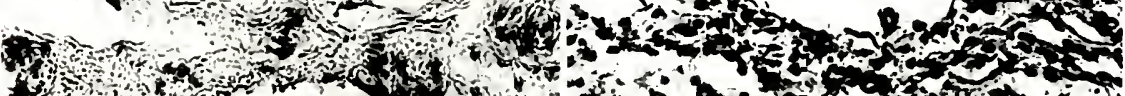

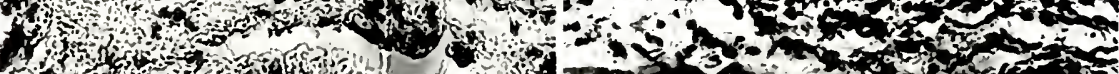

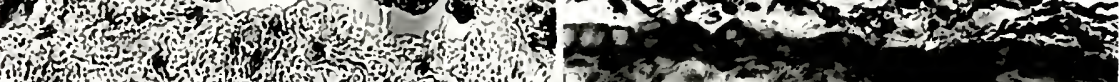

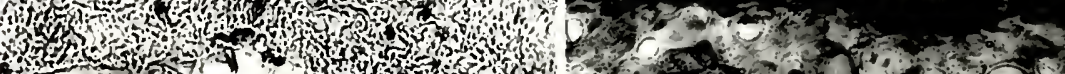

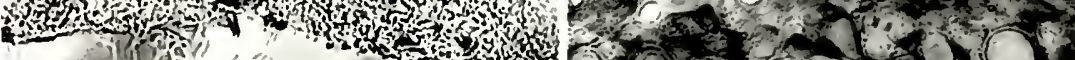

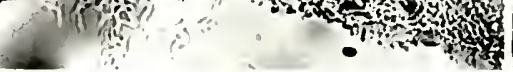




\section{REFERENCES}

Aitken, J.M., E. Armstrong and J.B. Anderson. 1972. Osteoporosis after oophorectomy in the mature female rat and the effect of oestrogen and/or progestogen replacement therapy in its prevention. J. Endocrinol. 55:79.

Arvy, L. 1955. Effect of injections of oestrogen on the mast cells of the white mouse. Nature 175:506.

Asboe-Hansen, G. 1956. Hormone effects on mast cells. Acta Endocrinol. 22:157.

Asher, J.D. and G. Nichols. 1965. Heparin stimulation of bone collagenase activity. Fed. Proc. 24:211 (Abstr.)

Bêlanger, L.F. 1977. Variations in the mast cell population of skin and bone marrow in magnesium-deprived rats. The influence of sex hormones. J. Nutr. $107: 2164$.

Bélanger, L.F. 1978. The influence of zinc-deprivation on the mast cell population of the bone marrow and other tissues. J. Nutr. 108:1315.

Bélanger, L.F., D.H. Copp and M.A. Morton. 1965. Demineralization with EDTA by constant replacement. Anat. Rec. 153:41.

Bois, P. 1962. Effect of magnesium deficiency on mast cells and urinary histamine in rats. Br. J. Exp. Pathol. 44:151.

Bonucci, E., V.L. Cascio, S. Adami, L. Cominacini, G. Galvanini and A. Scuro. 1978. The ultrastructure of bone cells and bone matrix in human primary hyperparathyroidism. Virchows Arch. Pathol. Anat. 379:11.

Burkhardt, R. 1973. Diagnose und therapie der osteoporose. Münchener Med. Wschr. 43:1915.

Burkhardt, S.L. and W.A. Beresford. 1978. An osteoporosis after the castration of full-grown rats. Anat. Rec. $190: 351$ (Abstr.)

Calonius, P.E.B. 1960. Occurrence of mast cells in gingivae, cicatritial tissue after extraction and connective tissue under compression. Dent. Abstr. 5:356. 
Carranza, F.A. and R.L. Cabrini, 1955. Mast cells in human gingiva. Oral Surg. 8:1093.

Cass, R., Marshall, P.B. and J.F. Riley. 1958. 5-Hydroxytryptamine and histamine in mast cells of the mouse and rat. J. Physiol. 141:510

Combs, J.W., D. Lagunoff and E.P. Benditt. 1965. Differentiation and proliferation of embryonic mast cells of the rat. J. Cell Biol. 25:577.

Constantinides, P. and J. Rutherdale. 1954. Effects of aging and endocrines in mast cells. Anat. Rec. $118: 379$.

Coombs, R.R.A. and P.G.H. Gell. 1975. Classification of allergic reactions responsible for clinical hypersensitivity and disease. In: Gell, P.G.H., R.R.A. Coombs and P.J. Lackman (Eds.) Clinical Aspects of Immunology, pp. 761-781. (3rd Ed.), Blackwell Scientific Publications, Oxford.

Cruess, R.L. and K.C. Hong. 1979. The effect of long term estrogen administration on bone metabolism in the female rat. Endocrinology 104:1188.

Dummett, C.O., T.E. Bolden and J.C. Ashurst. 1961. Mast cell density in diphenylhydantoin sodium gingival hyperplasia. J. Dent. Res. 40:921.

Feik, S.A. and E. Storey. 1979. Low-calcium/high phosphorus rickets in rats. I. Mast cell changes. Pathology $11: 641$.

Fick, K.R., L.R. McDowell, P.H. Miles, N.S. Wilkinson, J.D. Funk and J.H. Conrad. 1979. Methods of Mineral Analysis for Plant and Animal Tissues (2nd Ed.) Animal Science Dep., Univ. of Florida, Gainesville.

Frame, B. and R.K. Nixon. 1968. Bone marrow mast cells in osteoporosis of aging. N. Engl. J. Med. 279:626.

Gillman, T. 1958. Mast cell increase after calciferol intoxication and in experimental odoration. Acta Haematol. 19:179.

Goldhaber, P. 1965. Heparin enhancement of factors stimulating bone resorption in tissue culture. Science $147: 407$.

Griffith, G.C., G. Nichols, Jr., J.D. Asher and B. Flanagan. 1965. Heparin osteoporosis. J. Am. Med. Assoc. $193: 85$. 
Gumbreck, L.G. 1957. Castration, thyroidectomy and parabiosis in rats with particular reference to the pituitary basophil cells and their hormone products. Am. J. Anat. $101: 321$.

Harvey, E.B. 1964. Mast cell distribution in the uterus of cycling and pregnant hamsters. Anat. Rec. 148:507.

Hegsted, D.M. 1969. Mast cells, heparin, and osteoporosis. Nutr. Rev. 27:43.

Helander, H.F. and G.D. Bloom. 1974. Quantitiatve analysis of mast cell structure. J. Microsc. 100:315.

Iversen, O. 1962. The influence of oestrogenic and androgenic hormones on mast cells. Acta Pathol. Microbiol. Scand. $56: 245$.

Jaffe, M.D. and P.W. Willis. 1965. Multiple fractures associated with long-term sodium heparin therapy. J. Am. Med. Assoc. 193:158.

Jacques, L.B., J. Mahadoo and J.F. Riley. 1977. The mast cell/heparin paradox. Lancet 1:411.

Johansson, H. and B. Westin. 1959. Studies on the influence of oestrogen on the mast cells in mice. Acta Pathol. Microbiol. Scand. 45:133.

Jorpes, E., H. Holmgren and O. Wilander. 1937. Uber das vorkommen von heparin in den gefässwänden und in den augen. Ein beitrag zur physiologie der Erlichschen mastzellen. Z. Mikrosk. Anat. Forsch. 42:279.

Kaliner, M.A. 1979. The mast cell--A fascinating riddle. N. Engl. J. Med. 301:498.

Kameswaran, L., N.M. Krishna, N.N. Gopal, M.P. Nareshkumar, S. Parvathavarthini, and C.N. Subramanian. Study of hormonal influences on mast cells in rats. Indian $\mathrm{J}$. Med. Res. 67:795.

Kruse, H.P., F. Kuhlencordt, and U. Wernecke. 1973. Die bedeutung der mastzellen in knochenmarke bei der osteoporose. Deutsche Med. Wschr. 50:2388.

Lindgren, J.U. and T.S. Lindholm. 1979. Effect of 1-alphahydroxyvitamin $D_{3}$ on osteoporosis in rats induced by oophorectomy. Calc. Tiss. Int. 27:161. 
Lindholm, R., S. Lindholm and P. Liukko. 1967. Mast cells and fracture repair. Ann. Med. Exp. Fenn. 45:110.

Lindholm, R., S. Lindholm, P. Luikko, J. Paasimaki, S. Isohaanta, R. Rossi, E. Autio and E. Tamminen. 1969. The mast cell as a component of callus in healing fractures. J. Bone Joint Surg. 51B:148.

Lindholm, T.S., R. Hackman, R.V. Lindholm and P. Kinnunen. 1972. Fracture callus and meat cells in rats with calcium and vitamin D deficiency. Acta Orthop. Scand. $43: 221$.

Norland Corporation. 1980. Digital Bone Densitometer Model 278 Instruction Manual No.278M080A. Fort Atkinson, WI, pp.34-35.

Norton, L.A., W.R. Proffit and R.R. Moore. 1969. Inhibition of bone growth in vitro by endotoxin histamine effect. Nature 221: $\overline{469}$.

Pathak, C.L. and S. Goyal. 1973. Comparative study of various methods used for staining the mast cells. Indian J. Med. Sci. 27:173.

Peart, K.M. and H.A. Ellis. 1975. Quantitative observations on iliac bone marrow mast cells in chronic renal failure. J. Clin. Pathol. 28:947.

Puhl, J.J., G. Piotrowski and W.F. Enneking. 1972. Biomechanical properties of paired canine fibulas. J. Biomech. 5:391.

Rahima, A. and A.L. Soderwall. 1977. Mast cells in uteri of pregnant, young and senescent female golden hamsters. Biol. Reprod. 17:523.

Rasmussen, P. 1972. An experimental study of mast cells in the rat metaphysis. Calc. Tiss. Res. 9:325.

Riley, J.F. 1959. The Mast Cells. E. \& S. Livingstone, Ltd., Edinburgh and London.

Riley, J.F. 1962. Histamine and heparin in mast cells. Why both? Lancet $2: 40$.

Rockoff, S.D. and J.D. Armstrong, Jr. 1970. Parathyroid hormone as a stimulus to mast cell accumulation in bone. Calc. Tiss. Res. 5:49.

Sagher, F., E. Liban, H. Ungar and S. Schorr. 1956. Urticaria pigmentosa with bone involvement. J. Invest. Dermatol. 27:355. 
SaIvi, F. 1952. Comportamento delle mastzellen e delle sostanze cromotrope diffuse nell'apparato genitale femminile. (Translated: Behavior of mast cells and chromotropic substances disseminated in the female genital system.) Minerva Ginecol. 4:634.

Sanchez, T.V., R.C. Myers, J.T. Bond and G.H. Mayor. 1981. Bone mineral analysis of the rat femur by direct photon absorptiometry. Calc. Tiss. 33:586.

Saville, P.D. 1969. Changes in skeletal mass and fragility with castration in the rat: a model of osteoporosis. J. Am. Geriatr. Soc. 17:155.

Schiff, M. and H.F. Burn. 1961. The effect of estrogens on mast cells and enzymes in connective tissue metabolism in humans. Laryngoscope 71:765.

Schubert, M.A. 1968. A Primer on Connective Tissue Biochemistry. Lea \& Febiger, Philadelphia.

Scow, R.O. 1952. Effect of testosterone on muscle and other tissues and on carcass composition in hypophysectomized, thyroidectomized, gonadectomized male rats. Endocrinology 51:42.

Severson, A.R. 1969. Mast cells in areas of experimental bone resorption and remodeling. Br. J. Exp. Pathol. $50: 17$.

Shapiro, S., M. Ulmansky and M. Scheuer. 1969. Mast cell population in gingiva affected by chronic destructive periodontal disease. J. Periodontol. 40:276.

Shipley, P.G. and E.A. Park. 1922. Is there more than one kind of rickets? Am. J. Dis. Child 23:91.

Smith, D.E. and L.S. Lewis. 1958. Influence of hormones and $x$-rays upon the tissue mast cell. Experientia $14: 335$.

Smith, N. 1974. Mast cells in healing extraction sockets of calcium-deficient rats. Oral Surg. 38:378.

Sognnaes, R.F. 1965. Fluoride protection of bones and teeth. Science 150:989.

Spicer, S.S. 1960. A correlative study of the histochemical properties of rodent acid mucopolysaccharides. J. Histochem. Cytochem. $8: 18$.

Steel, R.G.D. and J.H. Torrie. 1960. Principles and Procedures of Statistics. McGraw-Hill Book Co., Inc., New York. 
te Velde, J., F.J.F.E. Vismans, L. Leenhurs-Binnedijk, C.J. Vos, D. Smeenk and O.L.M. Bijvoet. 1978. The eosinophilic fibrohistiocytic lesion of the bone marrow. Virchows Arch. Pathol. Anat. 377:277.

Urist, M.R. 1971. Osteoporosis in Post-Menopausal Women. Med. Folio $3: 1$.

Urist, M.R. and F.C. McLean. 1957. Accumulation of mast cells in endosteum of bones of calcium deficient rats. Arch. Pathol. 63:239.

Van Pelt, L.F. 1977. Ketamine and zylazine for surgical anesthesia in rats. J. Am. Vet. Med. Assoc. 171:842.

Walker, S. 1970. Increased mast cells in regenerating marrow of normal and hypophysectomized rats. Proc. Soc. Exp. Biol. Med. 135:245.

Westin, B. and E. Odeblad. 1956. The acute influence of some ovarian hormones on the occurrence of mast cells in the mouse vagina. Acta Path. Microbiol. Scand. $39: 81$.

Wilhelm, D.L., L.C.J. Yong and S.G. Watkins. 1978. The mast cell: Distribution and maturation in the rat. Agents Actions 8:146.

Wink, C.S. and W.J.L. Felts. 1980. Effects of castration on the bone structure of male rats: A model of osteoporisis. Calc. Tiss. Int. $32: 77$.

Wise, P.H. and A.J. Hall. 1980. Heparin-induced osteopenia in pregnancy. $\mathrm{Br}$. Med. J.

Yong, L.C., S. Watkins and D.L. Wilhelm. 1975. The mast cell: Distribution and maturation in the peritoneal cavity of the adult rat. Pathology 7:111.

Zwillenberg, L.O. 1958. The dendritic cell system and mast cells in non-epidermal stratified squamous epithelium. Nature $181: 1343$. 


\section{BIOGRAPHICAL SKETCH}

Rogene E. Kresak Tesar was born on June 5, 1938, on a farm near Western, Nebraska. After attending and graduating from Milligan High School, Milligan, Nebraska, as valedictorian of her class in 1956, she attended the University of Nebraska at Lincoln for two years. In 1957 she married Delbert Tesar; two daughters were born to this union. Upon moving to Manhattan, Kansas, she continued her education and obtained a Bachelor of Science in Home Economics degree in 1962.

That same year, Rogene and her family moved to Atlanta, Georgia. She taught in the Dekalb County Public School System for two years.

The next eight years included living for a year in Vienna, Austria, moving to Gainesville, Florida, having two additional children, and living for a year in Cheshire, England.

In 1973, she enrolled at the University of Florida and completed another Bachelor of Science degree in 1977; the major was food science. Immediately, she began graduate studies and graduated with a Master of Agriculture degree in food science and human nutrition at the University of Florida in 1979. At this time, she also became a Registered Dietitian after training at North Florida Regional Hospital. 
Continuing graduate work in the Department of Animal Science specializing in nutrition, she obtained a graduate research assistantship at the University of Florida and became involved in research and professional counseling, principally concerning bone loss and osteoporosis, at the Center for Climacteric Studies. In December, 1980, she became a candidate for the Ph.D. After completing the required research and dissertation, she received the Doctor of Philosophy degree in May, 1982. 
I certify that I have read this study and that in my opinion it conforms to acceptable standards of scholarly presentation and is fully adequate, in scope and quality, as a dissertation for the degree of Doctor of Philosophy.

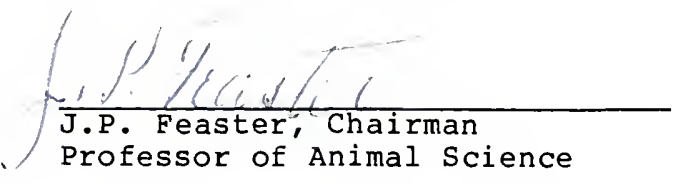

I certify that I have read this study and that in my opinion it conforms to acceptable standards of scholarly presentation and is fully adequate, in scope and quality, as a dissertation for the degree of Doctor of Philosophy.

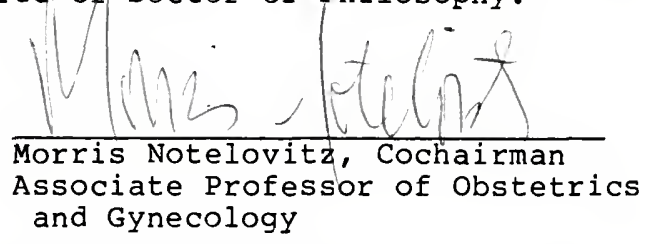

I certify that I have read this study and that in my opinion it conforms to acceptable standards of scholarly presentation and is fully adequate, in scope and quality, as a dissertation for the degree of Doctor of Philosophy.

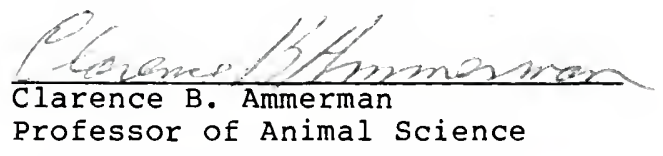

I certify that I have read this study and that in my opinion it conforms to acceptable standards of scholarly presentation and is fully adequate, in scope and quality, as a dissertation for the degree of Doctor of Philosophy.

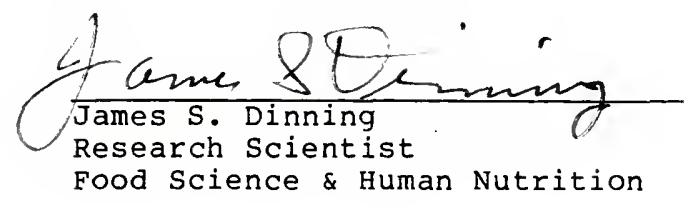


This dissertation was submitted to the Graduate Faculty of the College of Agriculture and to the Graduate Council, and was accepted as partial fulfillment of the requirements for the degree of Doctor of Philosophy.

May 1982

Dean, College of Agriculture

Dean for Graduate Studies and Research 
UNIVERSITY OF FLORIDA

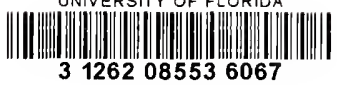

